University of Louisville

ThinkIR: The University of Louisville's Institutional Repository

Electronic Theses and Dissertations

8-2010

\title{
A role for regulatory $T$ cells in gender-biased disease susceptibility to murine lupus.
}

Colleen Tucker

University of Louisville

Follow this and additional works at: https://ir.library.louisville.edu/etd

\section{Recommended Citation}

Tucker, Colleen, "A role for regulatory T cells in gender-biased disease susceptibility to murine lupus." (2010). Electronic Theses and Dissertations. Paper 1465.

https://doi.org/10.18297/etd/1465

This Doctoral Dissertation is brought to you for free and open access by ThinkIR: The University of Louisville's Institutional Repository. It has been accepted for inclusion in Electronic Theses and Dissertations by an authorized administrator of ThinkIR: The University of Louisville's Institutional Repository. This title appears here courtesy of the author, who has retained all other copyrights. For more information, please contact thinkir@louisville.edu. 


\title{
A ROLE FOR REGULATORY T CELLS IN GENDER-BIASED DISEASE SUSCEPTIBILITY TO MURINE LUPUS
}

By

\author{
Colleen Tucker
}

\begin{abstract}
A Dissertation
Submitted to the Faculty of the

Graduate School of the University of Louisville

in Partial Fulfillment of the Requirements

for the Degree of
\end{abstract}

\section{Doctor of Philosophy}

Department of Microbiology and Immunology

University of Louisville

Louisville, Kentucky 



\section{A ROLE FOR REGULATORY T CELLS IN GENDER-BIASED DISEASE SUSCEPTIBILITY \\ TO MURINE LUPUS}

By

Colleen Tucker

A Dissertation Approved on

June 17, 2010

by the following Dissertation Committee

Dissertation Director 


\section{DEDICATION}

This dissertation is dedicated to my parents

Cy and Marcy Tucker

who have shown me unending love and support. 


\section{ACKNOWLEDGEMENTS}

I would first like to thank my mentor, Dr. Michele Kosiewicz for her guidance on this project. She has taught me so much about being a scientist: how to design experiments, how to think critically, and how to interpret data. Her door has always been open throughout my time in her lab and I have truly enjoyed being her student.

I would also like to thank Dr. Pascale Alard for her support throughout my time as a graduate student. Her comments in lab meetings and her vast knowledge of the literature have been invaluable. I would like to thank the other members of my committee as well: Dr. Esma Yolcu, Dr. Tom Mitchell, and Dr. Jun Yan. Their suggestions and insight on my project have been so helpful over the past several years.

I must thank all my fellow lab members, both past and present. They have not only been very helpful in my research, but have been dear friends. I'd like to especially thank Sarah Parnell and Dr. Yuan Zhao, both were very patient with me when I started in the lab and taught me everything I know about bench work. Their friendship and help has meant a lot to me. Without their help, along with other former members, including Dr. Jean Manirarora and my predecessor Dr. Doreen Nebane-Ambe, I could never have completed this project.

Finally, I would like to thank my friends and family who have supported me throughout this long and stressful process. I am so lucky to have such a great group of people to cheer me on. I don't know what I would have done without all of you. I'd like 
to thank my grandfather, Grayson Tucker, for being so supportive and interested in my research. I'd like to give a special thanks to Ty Leitner for sticking with me through this whole process and making my life a little easier. And an extra special thanks to my family: my sister, Ally, and my parents, Marcy and Cy. I have the best, most supportive family in the entire world. Thank you for always making me feel so loved. I am so lucky to have you. 


\section{ABSTRACT \\ A ROLE FOR REGULATORY T CELLS IN GENDER-BIASED DISEASE SUSCEPTIBILITY TO MURINE LUPUS}

\section{Colleen Tucker}

June 17, 2010

Females are more susceptible to autoimmune disease than males. In several mouse models of disease, castration of males exacerbates disease while androgen treatment ameliorates disease. These data suggest hormones can have an influence on disease susceptibility and progression. Regulatory T cells (Tregs), particularly the $\mathrm{CD}^{+} \mathrm{CD} 25^{+}$Tregs, have been shown to be important in controlling autoimmune disease. Studies have shown that depleting regulatory $\mathrm{T}$ cells can cause severe autoimmune disease, and increasing regulatory $\mathrm{T}$ cell population size can protect from disease. We hypothesized that gender differences in regulatory $\mathrm{T}$ cell populations would correlate with differences in disease susceptibility. We used a spontaneous mouse model of systemic lupus erythematosus, (NZBxNZW)F1 (BWF1), in which only females develop full-blown kidney disease to investigate gender differences in regulatory $\mathrm{T}$ cell 
percentages and function between females and males and their relationship to disease development.

First, we assessed differences in regulatory $\mathrm{T}$ cell function and number between young (before disease onset) female mice from four different strains, two autoimmune-

prone strains, BWF1 and SJL, and two more autoimmune-resistant strains, C57BL/6 and $\mathrm{BALB} / \mathrm{c}$. We found no differences in in vitro suppressive function by $\mathrm{CD} 4{ }^{+} \mathrm{CD} 25^{+}$Tregs from any of the four strains when co-cultured with either syngeneic $\mathrm{CD} 4^{+} \mathrm{CD} 25^{-}$ responders and $\mathrm{APCs}$ or $\mathrm{C} 57 \mathrm{BL} / 6 \mathrm{CD} 4^{+} \mathrm{CD} 25^{-}$responders and $\mathrm{APCs}$. We did, however, find lower percentages of $\mathrm{CD}^{+}$cells that expressed Foxp3 $\left(\mathrm{CD}^{+}{ }^{+} \mathrm{Foxp}^{+}{ }^{+}\right.$cells) in the periphery of BWF1 mice when compared to the other three strains of mice. The $\mathrm{CD}^{+} \mathrm{CD} 25^{+} \mathrm{CD} 103^{+}$cells are a potent memory/effector subset of regulatory $\mathrm{T}$ cells that are better suppressors than $\mathrm{CD} 4^{+} \mathrm{CD} 25^{+} \mathrm{CD} 103^{-}$Tregs both in vitro and in vivo. As found with the $\mathrm{CD} 4^{+} \mathrm{CD} 25^{+}$Tregs, we also found no differences in the suppressive function of $\mathrm{CD}^{+} \mathrm{CD} 25^{+} \mathrm{CD}_{103^{+}}$cells from any of the four strains of mice. However, percentages of $\mathrm{CD}^{+} \mathrm{CD} 25^{+} \mathrm{CD} 103^{+}$cells were, again, decreased in the periphery of BWF1 mice compared to the other three strains. We found that reduced percentages of both $\mathrm{CD}^{+}{ }^{+}$oxp $3^{+}$and $\mathrm{CD} 4^{+} \mathrm{CD} 25^{+} \mathrm{CD} 103^{+}$cells in the periphery of BWF1 mice were not due to defects in either thymic production or homeostatic proliferation of these cells. These data suggest that it may be the decreased Treg:Teffector cell ratio, and not a defect in inherent suppressive function, that render BWF1 mice more susceptible to autoimmune disease.

We next examined gender differences in regulatory $\mathrm{T}$ cell function and number between young female and male mice of the four strains. We found no differences in the 
suppressive ability of either $\mathrm{CD} 4^{+} \mathrm{CD} 25^{+}$or $\mathrm{CD} 4^{+} \mathrm{CD} 25^{+} \mathrm{CD} 103^{+}$Tregs between females and males of any strain. BWF1 mice were the only strain in which females had lower peripheral percentages of $\mathrm{CD}^{+}{ }^{+} \mathrm{Foxp} 3^{+}$cells than strain-matched males. Strikingly, females of all four strains had lower percentages of $\mathrm{CD} 4^{+} \mathrm{CD} 25^{+} \mathrm{CD} 103^{+}$cells in the periphery compared to strain-matched males. The lower percentages did not appear to be due to defects in either thymic production or homeostatic proliferation of the $\mathrm{CD}^{+}{ }^{+}$oxp $3^{+}$or $\mathrm{CD} 4^{+} \mathrm{CD} 25^{+} \mathrm{CD} 103^{+}$cells in females of any strain studied. Taken together these data suggest that decreased percentages of Tregs in the periphery of female BWF1 mice compared to BWF1 males and other mouse strains, and not an inherent defect in Treg suppressive function, may contribute to their increased susceptibility to systemic lupus erythematosus.

Finally, we assessed regulatory $\mathrm{T}$ cell function and number in BWF1 mice with established disease and compared age-matched ( $\sim 32-36$ weeks of age) sick (with proteinuria $\geq 300 \mathrm{mg} / \mathrm{dl}$ ) females, non-sick females and males. We found no differences in suppressive function of either $\mathrm{CD} 4^{+} \mathrm{CD} 25^{+}$or $\mathrm{CD} 4^{+} \mathrm{CD} 25^{+} \mathrm{CD} 103^{+}$cells from sick female, non-sick female or male mice when co-cultured with male $\mathrm{CD} 4^{+} \mathrm{CD} 25^{-}$ responders and male APCs in vitro. Surprisingly, we found significantly higher percentages of both $\mathrm{CD} 4^{+} \mathrm{Foxp} 3^{+}$and $\mathrm{CD} 4^{+} \mathrm{CD} 25^{+} \mathrm{CD} 103^{+}$cells in the periphery of sick females that were nearly three times that seen in non-sick females and males. To evaluate the relationship between progression of disease and regulatory $\mathrm{T}$ cell function and number, we examined regulatory $\mathrm{T}$ cells at several time-points throughout disease development. The lower percentages of both $\mathrm{CD} 4^{+} \mathrm{Foxp} 3^{+}$and $\mathrm{CD} 4^{+} \mathrm{CD} 25^{+} \mathrm{CD} 103^{+}$ regulatory cells found in young ( 9 week-old) pre-disease female BWF1 mice compared to 
age-matched males disappeared as mice aged, i.e., by 20-24 weeks of age. We hypothesized that the 9 weeks time-point (before disease onset) may represent an important period during which having reduced proportions of the potent $\mathrm{CD}^{+} \mathrm{CD} 25^{+} \mathrm{CD} 103^{+}$Treg population could render females more susceptible to disease. To determine whether decreasing the $\mathrm{CD} 4^{+} \mathrm{CD} 25^{+} \mathrm{CD} 103^{+}$Tregs at this critical timepoint could impact disease development later on, we depleted $\mathrm{CD}_{103^{+}}$cells by administration of anti-CD103 antibody bi-weekly then bi-monthly beginning at 8 weeks of age in female and male BWF1 mice. We found that $\mathrm{CD} 103^{+}$cell depletion early on accelerated disease onset and death in female BWF1 mice, and dramatically increased disease incidence and death in male BWF1 mice. These data suggest that 9 weeks may be a critical time-point in disease development and that reduced regulatory $\mathrm{T}$ cell populations in young pre-disease mice may render female BWF1 mice more susceptible to disease or alternatively, that higher regulatory $\mathrm{T}$ cell numbers in young pre-disease mice may help protect male BWF1 mice from disease.

The data presented in this dissertation suggest that reduced Treg:Teffector cell ratios and not an inherent defect in regulatory function may cause increased susceptibility to autoimmune disease. It also suggests that the potent $\mathrm{CD} 4^{+} \mathrm{CD} 25^{+} \mathrm{CD} 103^{+}$regulatory $\mathrm{T}$ cell population may be more sensitive to hormonal influences, as females of all four strains studied had lower peripheral percentages of these cells than strain-matched males. Finally, these data suggest that the early pre-disease time-point in BWF1 disease progression represents a critical period of time where a reduction in regulatory $\mathrm{T}$ cells can accelerate disease and death. 


\section{TABLE OF CONTENTS}

\section{PAGE}

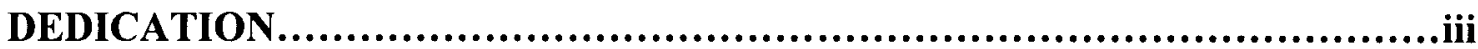
ACKNOWLEDGEMENTS ........................................................

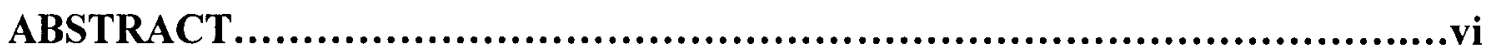

LIST OF FIGURES.............................................................iii

LIST OF TABLES...............................................................

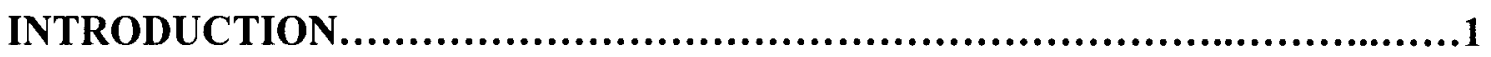

Gender differences in autoimmune disease ..................................

Systemic Lupus Erythematosus......................................... 8

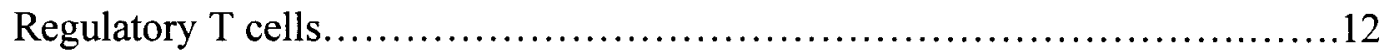

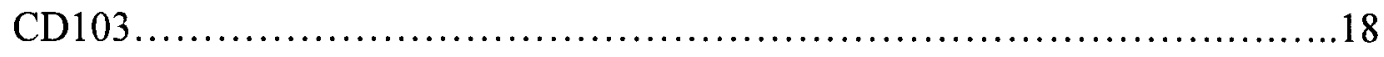

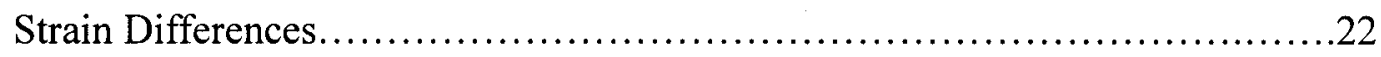

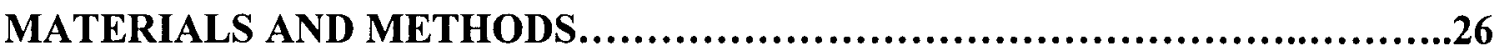

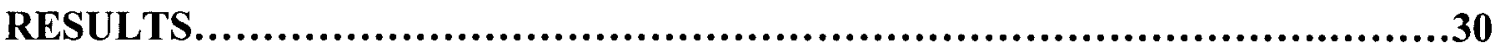

Specific Aim 1. Assessing regulatory $T$ cell populations in young autoimmune-prone and less-autoimmune-prone strains of mice...............30 
$\mathrm{CD}^{+} \mathrm{CD} 25^{+}$regulatory cells from young female $\mathrm{C} 57 \mathrm{BL} / 6, \mathrm{BALB} / \mathrm{c}, \mathrm{SJL}$, and BWF1 mice function similarly in an in vitro suppression assay

BWF1 mice have very low percentages of peripheral $\mathrm{CD} 4^{+} \mathrm{Foxp} 3^{+}$cells by comparison to other strains of mice

BWF1 and SJL mice have low percentages of peripheral $\mathrm{CD} 4^{+} \mathrm{CD} 25^{+} \mathrm{CD} 103^{+}$ cells.

Neither thymic production nor proliferation rate appear to account for the differences in either $\mathrm{CD} 4^{+} \mathrm{Foxp} 3^{+}$cells or $\mathrm{CD} 4^{+} \mathrm{CD} 25^{+} \mathrm{CD} 103^{+}$cells percentages in the periphery between strains

Specific Aim 2. Decrease in regulatory $T$ cell percentages, but not function, may contribute to female susceptibility to autoimmune disease.

$\mathrm{CD} 4^{+} \mathrm{CD} 25^{+}$regulatory cells from young female $\mathrm{C} 57 \mathrm{BL} / 6, \mathrm{BALB} / \mathrm{c}, \mathrm{SJL}$, and BWF1 mice function similarly to strain-matched males in an in vitro suppression assay .54

Female lupus-prone BWF1 mice have significantly lower percentages of

CD4 ${ }^{+}$Foxp $3^{+}$Tregs than BWF1 males

Female mice from all four strains have significantly lower percentages of the potent $\mathrm{CD} 4^{+} \mathrm{CD} 25^{+} \mathrm{CD} 103^{+}$regulatory $\mathrm{T}$ cell subset. .56 Thymic production of $\mathrm{CD} 4^{+} \mathrm{Foxp} 3^{+}$or $\mathrm{CD} 4^{+} \mathrm{CD} 25^{+} \mathrm{CD} 103^{+}$Tregs does not play a role in the lower percentage of these cells in the periphery .57

Differences in non-Treg proliferation in vivo may account for decreased $\mathrm{CD} 4^{+} \mathrm{Foxp} 3^{+}$peripheral percentages in female BWF1 mice, but proliferation does 
not appear to play a role in decreased female $\mathrm{CD} 4^{+} \mathrm{CD} 25^{+} \mathrm{CD} 103^{+}$peripheral

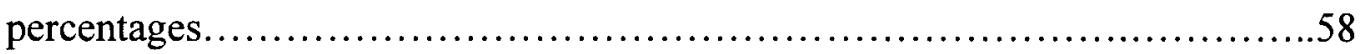

Specific Aim 3. Assessing regulatory $T$ cell changes throughout disease progression in lupus-prone (NZBxNZW)F1 mice...........................86

Sick female BWF1 mice had no defect in suppressive function in vitro, and had higher percentages of $\mathrm{CD} 4^{+} \mathrm{Foxp} 3^{+}$cells in the periphery than age-matched nonsick females and males.

Sick females had a higher percentage of $\mathrm{CD} 4^{+} \mathrm{CD} 25^{+} \mathrm{CD} 103^{+}$cells than agematched non-sick females and males with no defect in suppressive function in vitro.

Sick female Tregs were unable to control effector $\mathrm{T}$ cell proliferation in vivo....90 Sick female Tregs were able to traffic to kidney LN.

Regulatory $\mathrm{T}$ cell percentages change with disease progression in BWF1 mice..92 At nine weeks of age, pre-disease female BWF1 mice had no defect in Treg suppressive function in vitro but may be unable to control effector $\mathrm{T}$ cell proliferation in vivo.... .94 Pre-disease CD103-depletion in vivo accelerated and enhanced disease in female and male lupus-prone BWF1 mice. .96

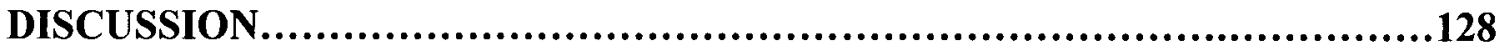

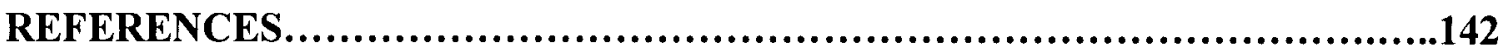

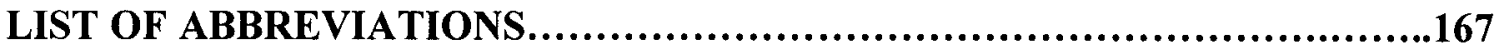

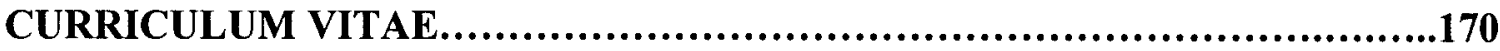




\section{LIST OF FIGURES}

PAGE

\section{FIGURE}

1. Regulatory function of $\mathrm{CD}^{+} \mathrm{CD} 25^{+}$cells from four strains of mice.............39

2. Percentages and numbers of $\mathrm{CD} 4^{+} \mathrm{Foxp} 3^{+}$cells in four strains of mice...........40

3. Regulatory function and percentages of $\mathrm{CD} 4^{+} \mathrm{CD} 25^{+} \mathrm{CD} 103^{+}$cells in the periphery of four strains of mice.

.42

4. Percentages of $\mathrm{CD} 4^{+} \mathrm{Foxp} 3^{+}$and $\mathrm{CD} 4^{+} \mathrm{CD} 25^{+} \mathrm{CD} 103^{+}$cells in thymus of four strains of mice

5. Percentages of proliferating $\mathrm{CD} 4^{+} \mathrm{Foxp} 3^{+}, \mathrm{CD}^{+} \mathrm{Foxp} 3^{-}$and $\mathrm{CD} 4^{+} \mathrm{CD} 25^{+} \mathrm{CD} 103^{+}$ cells in the periphery of four strains of mice.

6. Percentages and numbers of $\mathrm{CD} 4^{+}$cells and numbers of $\mathrm{CD}^{+} \mathrm{CD} 25^{+} \mathrm{CD} 103^{+}$ cells.

7. In vitro analysis of suppression by $\mathrm{CD} 4^{+} \mathrm{CD} 25^{+}$and $\mathrm{CD} 4^{+} \mathrm{CD} 25^{+} \mathrm{CD} 103^{+}$cells from four strains of mice.

8. Regulatory function of female and male $\mathrm{CD} 4{ }^{+} \mathrm{CD} 25^{+}$cells from four strains of mice.

9. Percentages and numbers of $\mathrm{CD} 4^{+} \mathrm{Foxp}^{+}$cells in four strains of mice. 62

10. Percentages and suppressive function in vitro of $\mathrm{CD} 4^{+} \mathrm{CD} 25^{+} \mathrm{CD} 103^{+}$cells in four strains of mice 65 
11. Percentages of $\mathrm{CD} 4^{+} \mathrm{Foxp} 3^{+}$and $\mathrm{CD} 4^{+} \mathrm{CD} 25^{+} \mathrm{CD} 103^{+}$cells in thymus in four strains of mice.

12. Percentages of proliferating $\mathrm{CD} 4^{+} \mathrm{Foxp} 3^{+}, \mathrm{CD} 4^{+} \mathrm{Foxp} 3^{-}$and $\mathrm{CD} 4^{+} \mathrm{CD} 25^{+} \mathrm{CD} 103^{+}$ cells in the periphery of four strains of mice. .70

13. Disease progression in our facility 98

14. Regulatory function in vitro in 32-36-week-old BWF1 mice

15. Percentages and numbers of $\mathrm{CD} 4^{+} \mathrm{Foxp}^{+}$cells in 32-36-week-old BWF1 mice. .101

16. Percentages and in vitro suppressive function of $\mathrm{CD} 4^{+} \mathrm{CD} 25^{+} \mathrm{CD} 103^{+}$cells in 3236-week-old BWF1 mice. 103

17. Percentages of $\mathrm{CD} 4^{+} \mathrm{Foxp} 3^{+}$and $\mathrm{CD} 4^{+} \mathrm{CD} 25^{+} \mathrm{CD} 103^{+}$cells in thymus of 32-36week-old BWF1 mice.

18. Percentages of proliferating $\mathrm{CD} 4^{+} \mathrm{Foxp} 3^{+}, \mathrm{CD}^{+} \mathrm{Foxp} 3^{-}$, and $\mathrm{CD} 4^{+} \mathrm{CD} 25^{+} \mathrm{CD} 103^{+}$ cells in the periphery of 32-36-week-old sick female, non-sick female, and male BWF1 mice. 106

19. Regulatory $\mathrm{T}$ cell percentages in kidney draining $\mathrm{LN}$ from 32-36-week-old BWF1 mice.

20. Percentages of $\mathrm{CD}^{+} \mathrm{CD} 25^{+} \mathrm{CD} 103^{+} \mathrm{CD} 62 \mathrm{~L}^{\text {hi }}$ cells in 32-36-week-old BWF1 mice.

21. Percentages of $\mathrm{CD}^{+} \mathrm{Foxp}^{+}$cells in BWF 1 mice.

22. Percentages of $\mathrm{CD} 4^{+} \mathrm{CD} 25^{+} \mathrm{CD} 103^{+}$cells in BWF1 mice 112

23. In vitro suppressive function of $\mathrm{CD}_{103^{+}}{ }^{+}$Tregs from $\mathrm{BWF} 1$ mice. 
24. Disease timeline and anti-CD103 monoclonal antibody treatment in BWF1

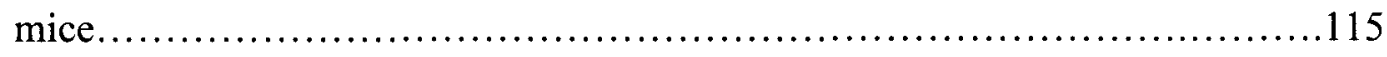

25. Regulatory function in vitro of cells from 9-week-old BWF1 mice...............116

26. In vivo CD103-depletion in pre-diseased BWF1 mice........................118

27. Disease incidence and survival in CD103-depleted BWF1 mice...............119 


\section{LIST OF TABLES}

PAGES

\section{TABLE}

1. Thymic weights and cell numbers in thymus, lymph nodes, and spleen in four

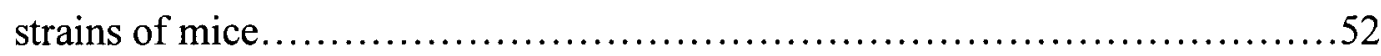

2. Percentages of $\mathrm{CD}^{+}$cells in four strains of mice............................72

3. Percentages of $\mathrm{CD}^{+}$cells that are Foxp $3^{+}$in four strains of mice................74

4. Numbers of $\mathrm{CD}^{+}$cells that are Foxp $3^{+}$in four strains of mice..................76

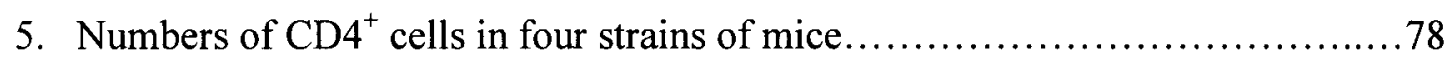

6. Per cell expression of Foxp3 on $\mathrm{CD}^{+}$cells in four strains of mice...............80

7. Numbers of $\mathrm{CD} 4^{+} \mathrm{CD} 25^{+} \mathrm{CD} 103^{+}$cells in four strains of mice....................81

8. Per cell expression of $\mathrm{CD} 103$ of $\mathrm{CD} 4^{+} \mathrm{CD} 25^{+}$cells in four strains of mice........83

9. Thymic weights and cell numbers in thymus, lymph nodes, and spleen in females

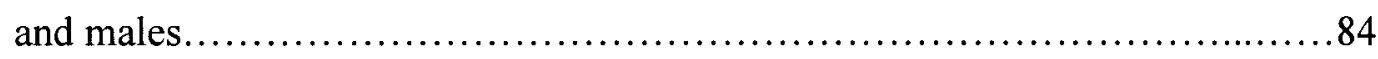

10. Thymic weights and cell numbers in thymus, lymph nodes, and spleen of 32-36week-old BWF1 mice.............................................. 123

11. Mean fluorescence intensity of Foxp3 on $\mathrm{CD}^{+}$cells in 32-36-week-old BWF1

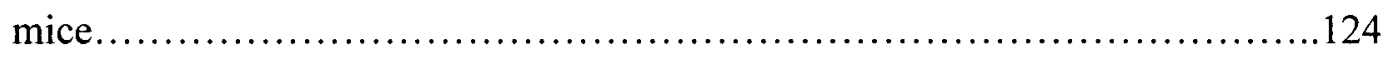

12. Numbers of $\mathrm{CD}^{+} \mathrm{CD} 25^{+} \mathrm{CD} 103^{+}$cells in 32-36-week-old BWF1 mice.........125

13. Percentages of $\mathrm{CD}^{+}$cells in 32-36-week-old BWF1 mice......................126 
14. Numbers of $\mathrm{CD}^{+}$cells in 32-36-week-old BWF1 mice......................127 


\section{INTRODUCTION}

\section{Gender Differences in Autoimmune Disease}

Women are more susceptible than men to most autoimmune diseases (1). This observation has prompted much research into sex differences and their effect on autoimmune disease susceptibility, particularly the effect of the differing hormonal environment on the immune system and disease incidence and progression (2-5). Females have stronger immune responses in general. In fact, female mice produce higher IgM and IgG antibody titers in response to antigens than males (6). Female $\mathrm{T}$ cells are also more reactive in a mixed leukocyte reaction than male $T$ cells (7). This increased strength of the female immune response is also seen in humans. Pre-pubertal females given the rubella vaccine have higher antibody titers than pre-pubertal males (8). Females have also been shown to have a higher CD4 to CD8 T cell ratio than males (9). Differences in the amounts and types of cytokines produced between males and females have also been seen in both humans and mice. Female BCG-sensitized mice challenged with PPD produce more IFN- $\gamma$ than males (10). $\mathrm{CD}^{+} \mathrm{T}$ cells from female multiple sclerosis patients can be induced to produce the anti-inflammatory cytokine IL-10 in response to high doses of estradiol, or the inflammatory cytokines IFN- $\gamma$ and TNF- $\alpha$ in response to low doses of estradiol, demonstrating a dose-dependent estrogen effect (11). Treatment of activated mouse $\mathrm{T}$ cells with the androgen dihydrotestosterone (DHT) resulted in decreased 
production of IL-4, IL-5, and IFN- $\gamma$ (12). The highly reactive female immune system is useful for fighting off infections and other foreign antigens, but presents a problem in individuals genetically predisposed to autoimmune disease where the immune system is primed to respond to self-antigens.

Exposure to estrogens that are either produced naturally in females or present in estrogenic compounds such as oral contraceptives, fertilizers, insecticides and other manmade compounds can increase the risk of autoimmune disease $(13,14)$. Estrogen promotes higher CD4 to CD8 T cell ratios and increased antibody production by activated B cells $(9,15)$. Estrogen receptors (ER) are expressed on a variety of immune cells, indicating estrogens can directly influence the immune system. In fact, $\mathrm{CD}^{+} \mathrm{T}$ cells, $\mathrm{CD}^{+} \mathrm{T}$ cells, $\mathrm{B}$ cells, macrophages, and both splenic and bone marrow-derived dendritic cells (DCs) express ER $(16,17)$. Estrogen receptor expression, and thus, the ability of estrogen to influence immune cells, varies with cell type and developmental stage (16-18). In fact, the differentiation of bone marrow cells into DCs requires physiological amounts of estradiol in vitro (19). The hormonal environment can affect the differentiation of B cells. The B cells from mice treated with estradiol develop into marginal zone cells, while B cells from mice treated with prolactin develop into follicular cells (20). Estradiol treatment may protect mice from developing experimental autoimmune encephalomyelitis (EAE) by reducing TNF- $\alpha$ production by $\mathrm{CD} 4^{+} \mathrm{T}$ cells and preventing recruitment of inflammatory $\mathrm{T}$ cells and macrophages into the central nervous system (CNS) (21).

Androgens can also have an effect on immune cells. Androgens can indirectly promote thymocyte apoptosis (22). B cell populations increase after castration of male 
C57BL/6 mice $(23,24)$. Castrated male mice also had decreased absolute numbers of $\mathrm{T}$ cells in their spleens, however, the few $\mathrm{T}$ cells they did have were highly activated, producing high levels of IL-2 and IFN- $\gamma$ (23). Exposure of pregnant female mice to dehydroepiandrosterone (DHEA), a weak androgen produced in response to stress, causes decreased function of $\mathrm{T}$ cells in their male offspring (25). Alternatively, it may be the androgen/estrogen balance and not the presence of estrogen or absence of androgen that causes autoimmune disease susceptibility. Rheumatoid arthritis (RA) patients tend to have low serum levels of testosterone and high levels of estrogens (26). This may be due to increased aromatase enzyme activity in RA patients converting androgens to estrogens (27). In fact, inflammatory cytokines like TNF- $\alpha$ and IL-6, known to be increased in autoimmune diseases like RA and lupus, have been shown to stimulate aromatase activity, thereby increasing estrogen production $(28,29)$. However, estrogens have been shown to induce inflammatory cytokine production (11), so it is difficult to determine cause and effect in this system.

Gender is such a strong determining factor in autoimmune disease susceptibility that a significant amount of research has gone into hormonal treatments for several autoimmune diseases (30). Female SJL mice are more susceptible than males to adoptively transferred EAE, a mouse model of multiple sclerosis (MS) (31, 32). In fact, in an adoptive transfer model where myelin basic protein (MBP) specific $\mathrm{T}$ cells from females with EAE are transferred into non-diseased females and males, females develop more severe EAE (33). Female MBP-specific T cells, which have more of a $\mathrm{T}_{\mathrm{H}} 1$ phenotype, are able to induce EAE with smaller numbers of adoptively transferred cells than male MBP-specific $\mathrm{T}$ cells, which have more of a $\mathrm{T}_{\mathrm{H}} 2$ phenotype (34). This $\mathrm{T}_{\mathrm{H}} 2$ bias 
in SJL males may contribute to the fact that they do not have relapses in induced-EAE, while their female counterparts do (35). This indicates that it is something about the female environment that increases disease severity. Female SJL mice treated with DHT 90-day release pellets develop less severe and eventually remitting disease than placebotreated females, that may be due in part to increased IL-10 production by MBP-specific T cells (31). Male SJL mice, which develop less severe disease in the adoptive transfer model of EAE, produce less IL-12 in draining lymph nodes than females with disease (36). Addition of IL-12 to male LN cells increases the MBP-specific response, indicating that IL-12 is an important cytokine in EAE disease progression (36). In a human study, 10 male MS patients were treated with a testosterone-containing gel. This testosterone treatment decreased $\mathrm{CD}^{+}$T cell numbers and IL-2 production while increasing TGF- $\beta$ production (37).

While there is no known gender bias in human type 1 diabetes, females predominantly develop disease in the non-obese diabetic (NOD) mouse model of type 1 diabetes (38), and this model has been used extensively in hormonal studies. Androgen treatment can prevent islet destruction in adult female NOD mice (39). However, androgen treatment could not prevent NOD mice from developing diabetes through adoptive transfer of diabetic $\mathrm{T}$ cells (39). These data indicate that androgen treatment may prevent or reduce the induction of pathogenic $\mathrm{T}$ cell development in female NOD mice, resulting in decreased islet destruction (39). Castration increases the incidence of diabetes in male NOD mice, while oophorectomy decreases disease incidence in female NOD mice (40). Thus, androgens may have a protective effect in type I diabetes whereas estrogens may have a disease-enhancing effect. In fact, $\mathrm{CD} 4^{+} \mathrm{T}$ cells from NOD mice 
treated with testosterone in vitro produce less of the inflammatory cytokine IFN- $\gamma$ in response to IL- 12 while $\mathrm{CD}^{+} \mathrm{T}$ cells treated with estrogen in vitro produce more IL-12induced IFN- $\gamma$ (41). These data support the hypothesis that the female bias toward developing type 1 diabetes in NOD mice may be due to increased estrogens and decreased androgens in diabetic females.

Rheumatoid arthritis (RA) is also more prevalent in females than males but is ameliorated during pregnancy, suggesting a role for sex hormones in disease susceptibility and progression $(42,43)$. Estrogens are present at high levels in the synovium of RA patients and are associated with increased inflammation at these sites (44). However, in rodent models of RA, the gender bias and hormonal influence on disease are more complicated. Different models of rheumatoid arthritis have different sensitivities to treatment with hormones. Castrated male rats develop accelerated and more severe adjuvant-induced arthritis than non-castrated males (45). However, in a type II collagen-induced model of rheumatoid arthritis in (B10QxDBA/1)F1 mice, in which males are more susceptible to disease, estrogen treatment suppresses disease in both castrated and non-castrated males while oophorectomy or testosterone treatment increases disease incidence in females (46). Physiologic levels of estrogen have also been used to treat castrated female DBA/1 mice with collagen-induced arthritis, ameliorating disease by suppressing $\mathrm{T}$ cell responses and stimulating B cell activity (47). Hormone replacement therapy, most commonly used after menopause, in human rheumatoid arthritis patients has not been shown, as it has in other autoimmune diseases, to be associated with disease flares, and may, in fact, reduce disease symptoms (48). However, human studies of RA are difficult to interpret because of small experimental population 
size (48). Thus, sex hormones may play an important, though complicated, role in rheumatoid arthritis development and/or treatment.

Females develop systemic lupus erythematosus (SLE) far more often than males, and much research has focused on the influence of sex hormones on this disease $(49,50)$. In fact, SLE symptoms worsen during pregnancy, a time when estrogen and prolactin levels are high, and these hormones can have differing effects on B cell development into either marginal zone or follicular B cells, respectively (51). In a study of 94 non-pregnant female SLE patients, a high percentage of these women were found to have abnormal levels of many hormones, including estrogen and prolactin (52). In a study of 78 pregnancies in SLE patients, $65 \%$ had increased flares during pregnancy (53). Administration of external estrogens, whether through use of oral contraceptives or estrogen replacement therapy in post-menopausal women, has been associated with increased SLE disease severity (54-58). Similar to RA patients, SLE patients tend to have higher serum levels of estrogen and lower serum levels of androgen, which may be due to increased aromatase activity, also seen in these patients (59). Estradiol, and synthetic estrogens and their metabolites can cause DNA damage, including strand breakage, oxidized base formation, and adduct formation (60). DNA that has been modified by estradiol is bound more readily by dsDNA autoantibodies in human lupus patients (61). SLE patients also have abnormal estrogen metabolism. Urine samples from SLE patients have been found to contain 16 $\alpha$-hydroxylated estradiol, a potent estrogen metabolite not normally found at high levels in urine $(62,63)$. Male patients suffering from SLE and Klinefelter's syndrome (XXY) have estrogen levels similar to female SLE patients (64). In one case study, a male Klinefelter's patient with SLE treated with physiologic levels of 
testosterone had decreased lupus symptoms, including a lower titer of anti-DNA antibodies (65). While testosterone treatment causes many unwanted side effects, these data suggest that development of an androgenic compound that does not cause such severe side effects could be very useful for the treatment of lupus.

(NZBxNZW)F1 (BWF1) is a mouse model of SLE in which only females spontaneously develop disease $(66,67)$. Castration of male BWF1 lupus-prone mice causes them to develop disease at similar rates and severity as BWF1 females (68). In addition, both castrated male and ovariectomized female BWF1 mice treated with estrogen show increased disease severity and decreased survival, while mice treated with androgens are protected from disease (68). Male BWF1 fetuses have increased circulating estradiol compared to control C57BL/6 fetuses, and treatment with testosterone can decrease estradiol in BWF1, but not C57BL/6 fetuses (69). These data suggest that the BWF1 background predisposes mice to produce high levels of inflammation-promoting estrogens, as even males have increased levels compared to other strains of mice (69). Estrogen has been shown to interact with the estrogen receptor in female lupus patients to promote $\mathrm{T}$ cell activation and B cell autoantibody production (70). Estrogen receptor- $\alpha$ $(E R \alpha)$ deficiency can attenuate disease in female BWF1 mice (71). This attenuation may be due to decreased levels of the estrogen-regulated cytokine, IFN- $\gamma$, high levels of which are present in the serum of lupus patients and lupus-prone mice (71). In BWF1 mice, removal of estrogen ameliorates disease symptoms, as can be seen when these mice are treated with tamoxifen, an anti-oestrogen, which reduces autoantibody production (72). These data indicate an important role for sex hormones in susceptibility to SLE. 
Differences in estrogen receptor signaling have also been found between strains of mice. Two lupus-prone mice, the BWF1 and MRL/MP-lpr/lpr strains, have decreased ER expression measured in the cytosol of cells of both the liver and the thymus compared to less autoimmune-prone BALB/c mice $(73,74)$. However, ERs from both lupus-prone strains had a higher binding affinity than ERs from BALB/c mice $(73,74)$. These differences in ER number and binding affinity may underlie some of the defects in estrogen signaling and metabolism seen in lupus patients and contribute to the susceptibility of patients and lupus-prone mice.

\section{Systemic Lupus Ervthematosus}

Systemic lupus erythematosus (SLE) is an autoimmune disease that predominantly affects women. There is evidence for a genetic basis for SLE $(75,76)$. Ten percent of lupus patients have at least one first degree relative with lupus (77). In a study of monozygotic twins, if one twin had lupus there was a $24-58 \%$ chance the second twin also had disease, while in dizygotic twins, it was only a $2-5 \%$ chance $(78,79)$. However, these data not only indicate that there is a strong genetic predisposition in lupus, but also suggest that there are strong environmental factors.

In SLE, antibodies are produced against self-antigens such as double-stranded DNA, histones, chromatin, other nuclear proteins, etc (80). These antibodies combine with complement to form immune complexes, which deposit in the kidneys eventually causing glomerulonephritis and death (80). Many cytokines like IFN- $\alpha$, TNF- $\alpha$, and IL10 are increased in the serum of both lupus patients and lupus-prone mice (81). SLE is a difficult disease to treat because there are such a wide variety of symptoms (82). Some 
patients develop CNS pathology or skin rashes, while others develop severe glomerulonephritis (83). This makes it difficult to identify potential therapeutic targets.

Lupus patients and lupus-prone mice have a defect in their ability to clear apoptotic cells (84). In fact, in two lupus-prone strains of mice, the MRL/lpr and BWF1 strains, disease manifestation is associated with decreased phagocytosis by macrophages (85). Accumulation of apoptotic cells can impact disease. For example, injection of apoptotic B and T cells into young lupus-prone BWF1 mice results in increased IL-6 and IL-10 production by macrophages, increased lymphocyte recruitment to the site of injection, and acceleration of disease (86). Injection of apoptotic B cells, but not apoptotic $T$ cells, induces a systemic $T_{H} 2$ response, resulting in $B$ cell autoantibody production and acceleration of disease (86).

Decreased apoptotic cell clearance may also affect DC function. DCs from lupusprone mice have a low activation threshold. High mobility group box protein 1 (HMGB1) is a molecule associated with apoptotic cell chromatin that may participate in breaking tolerance to double stranded DNA (dsDNA) and nucleosomes (87). HMGB1-containing nucleosomes from apoptotic cells, which are found at high levels in the plasma of SLE patients, induce DC maturation and secretion of proinflammatory cytokines like IL-1 $\beta$, IL-6, and IL-10 (87). DC from lupus-prone mice produce more inflammatory cytokines in response to anti-CD40 or LPS stimulation than wildtype mice (88). Defects in DC can also be seen in human lupus patients. Myeloid DC from human lupus patients display an abnormal phenotype that is characterized by increased expression of maturation markers and inflammatory cytokines, and consequently an increase in T cell proliferation (89). Kidney-infiltrating myeloid DC from lupus patients have been associated with increased 
levels of $\mathrm{Clq}$, a component of the classical complement pathway (90). Clq production in the kidneys is associated with disease and may lead to increased presentation of autoantigens (90).

While defects in many cellular compartments are associated with disease in SLE, infiltration of $\mathrm{T}$ cells into the kidney is necessary for the development of end-stage kidney disease (91). In fact, male NZM2328 lupus-prone mice, which develop autoantibodies in their serum but not end-stage kidney disease, do not have detectable DC and $\mathrm{T}$ cell infiltration in their kidneys, whereas female NZM2328 mice, which develop full-blown disease, have detectable DC and T cell kidney infiltration (91). Furthermore, removal of $\mathrm{T}$ cells, either by thymectomy or antibody-mediated $\mathrm{T}$ cell depletion, prevents lupus development in the MRL-lpr/lpr mouse model of lupus (92, 93). Injecting kidney cells from sick mice into the thymi of MRL-lpr/lpr lupus-prone mice can delay glomerulonephritis development, but not autoantibody production, apparently by deleting kidney-specific, autoreactive T cells from the developing T cell pool (94).

There are many genetic factors that contribute to the development of disease in lupus patients and lupus-prone mice, including polymorphisms of molecules involved in antigen presentation, cytokine production, and immune complex clearance (75). In a study of 91 caucasian families, an association between the class II MHC molecule HLADR2 and lupus has been observed (95). HLA-DR2 has been linked with development of autoantibodies against dsDNA $(96,97)$. Variations in cytokine genes are also seen in lupus. Polymorphisms in the gene encoding TNF- $\alpha$, a cytokine seen at reduced levels in the serum of both humans and mice with lupus compared to healthy controls, gene have also been found in both SLE patients and in lupus-prone mice (98-101). In another 
example, expression of certain FcyRII and FcyRIII alleles has been associated with disease in humans (102-107). These disease-associated $\mathrm{Fc} \gamma \mathrm{R}$ alleles may contribute to disease because these receptors bind less efficiently to IgG antibodies, preventing effective clearing of immune complexes $(105,108)$.

Mouse models have also been used to determine genetic factors contributing to SLE disease susceptibility. Morel and colleagues have used congenic mice to identify several susceptibility loci, including Sle la, Sle1b, and Sle1c (109). These three loci break tolerance to chromatin and result in the production of anti-chromatin antibodies (110). Sleb is associated with polymorphisms in the signaling lymphocyte activation molecule (SLAM)/CD2 gene family, which plays a role in cell activation and signaling (111). Sle la and Sle $1 \mathrm{c}$ have been shown to be involved in autoreactive $\mathrm{CD} 4^{+} \mathrm{T}$ cell generation and a reduction in the size of the $\mathrm{CD} 4^{+} \mathrm{CD} 25^{+}$regulatory $\mathrm{T}$ cell population $(109,112)$. Sle 1c has been mapped to the NZM2410 complement receptor $2(\mathrm{Cr} 2)$ allele (112). Polymorphisms in the $\mathrm{Cr} 2$ gene have also been found in human lupus patients $(113,114)$. The presence of the Sle la locus alone causes a decrease in the number, but not function, of $\mathrm{CD}^{+} \mathrm{CD} 25^{+} \mathrm{Foxp} 3^{+}$Tregs, and causes DC to increase production of IL-6, rendering $\mathrm{CD}^{+} \mathrm{CD} 25^{-} \mathrm{T}$ cells resistant to suppression $(115,116)$. Sle la has been broken down into two intervals, Slela.1 and Sle 1a.2 (117). Expression of both intervals is necessary for the Sle la phenotypes (117). A strong candidate gene for Sle la. 1 is Pbxl, which encodes a nuclear transcriptional regulator, is expressed by B cells and macrophages, and whose gene expression is seen in murine and human T cells (117). A strong candidate gene for Sle la. 2 is $S h 2 d l b$, which encodes Eat-2 (a SLAM associated protein involved in recruitment of Src kinases) and is expressed by natural killer cells, B cells, T cells, and 
DC (117). As seen in human SLE patients, certain MHC class II haplotypes have been associated with disease in lupus-prone mice on specific backgrounds. For example, H-2 ${ }^{\mathrm{d} / z}$ is associated with disease susceptibility in BWF1 mice (118-120). A deficiency in Fas, which mediates activation induced cell death, has also been associated with B cell production of autoantibodies in a mouse model of lupus $(121,122)$.

\section{$\underline{\text { Regulatory T Cells }}$}

Regulatory $\mathrm{T}$ cells (Tregs) have been shown to be important in controlling autoimmune disease $(123,124)$. Tregs are $\mathrm{CD} 4^{+}$cells that constitutively express IL-2 receptor $\alpha(\mathrm{CD} 25)(125)$. When $\mathrm{CD}^{+} \mathrm{CD} 25^{-} \mathrm{T}$ cells are adoptively transferred into $\mathrm{BALB} / \mathrm{c}$ athymic nude mice $(n u / n u)$ mice, they cause severe autoimmune disease that can be prevented by cotransfer of $\mathrm{CD} 4^{+} \mathrm{CD} 25^{+}$Tregs (125). $\mathrm{CD} 25$ is not an ideal marker for Tregs as it is also expressed on activated T cells and is not expressed on all Tregs (126). Foxp3 is a nuclear transcription factor with a forkhead-binding domain, encoded on the $\mathrm{X}$-chromosome, and is the most reliable Treg marker, at least in mice $(127,128)$. Foxp3 is required for Treg function and development $(127,129-134)$. In fact, Foxp3 deficient (scurfy) mice do not develop Tregs and males die of severe autoimmune/inflammatory disease by 21 days of age (127). Disease in scurfy mice is due to the absence of Tregs as these mice can be rescued from disease by adoptive transfer of $\mathrm{CD} 4{ }^{+} \mathrm{CD} 25^{+}$cells from wildtype mice (127). Immunodysregulation polyendocrinopathy enteropathy X-linked syndrome (IPEX), a severe disease affecting multiple organs, is also seen in humans with Foxp3 mutations (135). Foxp3 alone can confer regulatory ability. Retroviral gene transfer of Foxp3 into murine $\mathrm{CD} 4^{+} \mathrm{CD} 25^{-}$effector $\mathrm{T}$ cells causes them to develop a 
regulatory phenotype and function $(127,129)$. Foxp3's control of regulatory phenotype and function is dose-dependent. Ablation or attenuation of Foxp3 in Treg cells results in the loss of regulatory function and the development of severe autoimmune disease resembling that seen in scurfy mice $(130,132-134,136)$.

In humans, TCR engagement induces Foxp3 expression (137), and it has been shown that effector $\mathrm{T}$ cells can express Foxp3 transiently when they are activated (138). Epigenetic Foxp3 DNA methylation is one way to determine whether a Foxp $3^{+}$cell is a Treg or an activated $\mathrm{T}$ cell transiently expressing the transcription factor, as Tregs but not activated effector T cells are demethylated at the Foxp3 locus (139). This Treg-specific Foxp3 DNA methylation is not unique to human cells and has also been observed in mice $(140,141)$.

It is unknown whether Tregs suppress effector T cell proliferation in vivo by directly suppressing the effector T cells or indirectly through interactions with DCs (124). Using 2-photon microscopy, Bluestone and colleagues were able to detect interactions of Tregs with DCs, but not with effector T cells (142). After interaction with Treg cells, DCs had shorter interactions with effector T cells (142). CTLA-4 is constitutively expressed on Tregs and on activated T cells, and interacts with DC through CD80 and CD86 (143-145). Addition of a blocking anti-CTLA-4 mAb in vitro can prevent Treg suppression of effector T cell proliferation (146). Mice in which CTLA-4 has been conditionally knocked out develop severe autoimmune disease similar to that found in scurfy mice, suggesting that CTLA-4 is critical for Treg suppressive function in vivo (147). Tregs influence DC function but DCs can influence Treg function as well. High 
levels of IL-6 production by DCs can render effector T cells resistant to Treg-mediated suppression (148).

Another molecule expressed by $\mathrm{CD} 4^{+} \mathrm{CD} 25^{+}$Tregs is the glucocorticoid-induced TNF receptor (GITR) $(149,150)$. It has been shown that treatment with blocking antiGITR antibody can reduce Treg suppressive function both in vitro and in vivo $(149,150)$. However, GITR is also expressed on effector $\mathrm{CD}^{+}$and $\mathrm{CD} 8^{+} \mathrm{T}$ cells $(149,150)$. GITR acts as a costimulatory molecule for effector T cells, and treatment with anti-GITR antibody promotes proliferation and cytokine production (151). The decrease in Treg suppressive function seen with anti-GITR antibody treatment may in fact be due more to increased effector $\mathrm{T}$ cell proliferation.

Many factors control and impact Treg function (152). Naturally occurring $\mathrm{CD} 4{ }^{+} \mathrm{CD} 25^{+}$Tregs are activated by self-peptides presented by the MHC class II molecule in vivo (153). This activation allows Tregs to suppress in vitro without further TCR stimulation as long as IL-2 is present in culture (153). This may have relevance in vivo, as previously activated Tregs can suppress in a non-antigen specific manner in the presence of high enough levels of IL-2 or other cytokines (153). An interesting new finding reports that Tregs co-express Foxp3 along with transcription factors specific for $T_{H} 1$ or $T_{H} 2$ responses, such as interferon regulatory factor-4 (IRF-4) a molecule necessary for $T_{H} 2$ responses, to help them more selectively control the type of immune response occurring in the tissue in which they are located (154). MicroRNA molecules such as miRNA155 that are small single-stranded RNA molecules found in the cytoplasm that degrade transcription products have also been found to be important in controlling Treg function both in vivo and in vitro $(155,156)$. 
Tregs can also regulate B cells, a property that makes them an even more attractive target for SLE therapeutic treatment. Tregs have been shown to migrate to germinal centers and indirectly suppress B cells by suppressing the germinal center Thelper cells whose help is necessary for B cell function (157). Tregs can also directly suppress B cell Ig class switching and antibody production by inducing B cell apoptosis in both mice and humans $(158,159)$.

Regulatory T cells are a promising therapeutic target in SLE because they can interact with many different potentially autoreactive cell types and because reduced numbers of Tregs has been correlated with disease susceptibility in mice and disease progression in humans $(160,161)$. The correlation of Treg population size and function to disease in human lupus patients is controversial. Many groups have shown a reduced percentage of Tregs in the peripheral blood of active lupus patients as well as a reduction in regulatory function in suppression of cytokine production, in vitro suppression assays, and Foxp3 expression (162-164). Others have shown a reduction in Treg percentages in peripheral blood but no reduction in regulatory function or Foxp3 expression $(165,166)$. Still other groups have shown an increase in circulating $\mathrm{CD} 4^{+} \mathrm{Foxp} 3^{+}$cells but a decrease in $\mathrm{CD} 4^{+} \mathrm{CD} 25^{\text {hi }}$ cells $(167,168)$. Another group found increased $\mathrm{CD} 4^{+} \mathrm{CD} 25^{+}$cells in the peripheral blood of active lupus patients (169). Increasing Tregs with either plasmapheresis treatment or treatment with corticosteroids correlated with decreases in disease activity (168-170). Different groups may find such differences in Treg percentages and function because they are defining active phases of lupus differently or because they are defining $\mathrm{CD} 4^{+} \mathrm{Foxp} 3^{+}$or $\mathrm{CD} 4^{+} \mathrm{CD} 25^{+}$and not $\mathrm{CD} 4^{+} \mathrm{CD} 25^{\text {hi }} \mathrm{T}$ cells as Tregs. The importance of distinguishing Tregs from activated $\mathrm{T}$ cells in these studies is 
emphasized by the findings of Sakaguchi and colleagues. They have found a subset of human $\mathrm{CD}^{+} \mathrm{T}$ cells that co-express Foxp3 and RORC (an important transcription factor in $T_{H} 17$ cell development) and produce IL-17 (171).

Tregs have been extensively studied in mouse models of lupus as well. (NZBxNZW)F1 (BWF1) and (NZBxSWR)F1 (SNF1) mice, mouse models of lupus, display lower percentages of $\mathrm{CD}^{+} \mathrm{CD} 25^{+}$cells than non-autoimmune-prone $\mathrm{BALB} / \mathrm{c}$ and DBA/1 mice (172) or (DBA/2xNZW)F1 mice (173). However, these studies used CD25 as a marker instead of the more specific Treg marker, Foxp3, and Foxp3 mRNA expression is shown in the $\mathrm{CD} 4^{+} \mathrm{CD} 25^{-} \mathrm{T}$ cell subset of at least one of these studies (173). No difference in suppressive function was seen between BWF1 and (DBA/2xNZW)F1 $\mathrm{CD}^{+} \mathrm{CD} 25^{+}$cells in vitro (173). The reduction in $\mathrm{CD}^{+} \mathrm{CD} 25^{+}$cell percentages seen in BWF1 mice can be reversed by nasal tolerance induction with a histone peptide antigen H471 (172). Treatment of non-autoimmune (DBA/2xNZW)F1 mice with anti-CD25 monoclonal antibody increases serum levels of dsDNA autoantibodies (173), and treatment of female BWF1 mice starting at 3 days of age with anti-CD25 monoclonal antibody results in accelerated disease, including early development of high dsDNA autoantibody titers, increased serum levels of inflammatory cytokines, and glomerulonephritis (174). Neonatal thymectomy (i.e. interrupts Tregs development) of lupus-prone NZM2328 mice causes accelerated disease development, and adoptive transfer of $\mathrm{CD} 25^{+}$Tregs from asymptomatic mice ameliorates disease symptoms (175). In fact, several studies have shown that increasing the Treg population in lupus-prone mice can delay and/or ameliorate disease (176-179). Increasing the $\mathrm{CD} 4^{+} \mathrm{CD} 25^{+}$Treg population by tolerizing lupus-prone SNF1 mice with a histone peptide antigen injected 
subcutaneously every two weeks delays disease onset (176). Injection of a peptide based on the complementary-determining region 1 (hCDR1) every other day for a week starting at 8 weeks of age increases both $\mathrm{CD} 4^{+} \mathrm{CD} 25^{+}$Treg percentages and TGF- $\beta$ production and ameliorates disease in lupus-prone BWF1 mice (177). Adoptive transfer of ex vivoexpanded Tregs delays or prevents lupus development in BWF1 mice. $(178,179)$. Interactions of regulatory $\mathrm{T}$ cells and $\mathrm{APC}$ in lupus can impact Treg function. In humans, APC from active lupus patients produce high levels of IFN- $\alpha$, which may render Tregs non-functional (180). Treg function is restored when they are cultured with APC from healthy control patients (180). Mice expressing the NZM2410 lupus susceptibility locus Sle la produce high levels of IL-6, rendering $\mathrm{CD}^{+} \mathrm{CD} 25^{-}$effector T cells resistant to suppression by Tregs (115).

Tregs have been shown to be important in controlling many other autoimmune diseases. Decreased numbers of Tregs are also seen in the islets of a type 1 diabetes mouse model, the non-obese diabetic (NOD) mouse model (181). Reduced frequency of $\mathrm{CD}^{+}{ }^{+}$Foxp $3^{+}$Tregs and reduced Foxp 3 expression per cell are seen in MS patients (182). Adoptive transfer of Tregs, which results in the doubling of the Treg population reduces disease severity in a model of EAE (183). Cotransfer of $\mathrm{CD} 4{ }^{+} \mathrm{CD} 25^{+}$Tregs with diseasecausing $\mathrm{CD} 4^{+} \mathrm{CD} 45 \mathrm{RB}^{\text {high }} \mathrm{T}$ cells can prevent colitis (184).

Natural Tregs develop in the thymus where they are positively selected on a high affinity TCR (185). TGF- $\beta$ signaling is required for thymic development of Tregs (186). Thymically-derived Tregs have high TCR diversity, allowing them to regulate a wide variety of potentially autoreactive $T$ cells in the periphery (187). Thymic development of Tregs requires MHC class II, but an activated subset of Tregs can develop in the 
periphery of MHC class $\mathrm{II}^{-/}$mice $(188,189)$. Tregs can also develop independent of the thymus through peripheral conversion of $\mathrm{CD} 4^{+} \mathrm{CD} 25^{-}$effector $\mathrm{T}$ cells to $\mathrm{CD} 4^{+} \mathrm{CD} 25^{+}$ Tregs $(190,191)$. This conversion requires TCR stimulation, TGF- $\beta$, and B7 costimulation $(190,191)$. In fact, these TGF- $\beta$ converted cells, or inducible Tregs, function as well as natural Tregs to rescue scurfy mice from disease (192). It has been shown that, once activated, Tregs can suppress responder $\mathrm{T}$ cells in an antigen nonspecific manner (193). However, new evidence suggests that to promote organ-specific tolerance, antigen specific Tregs are critical (194). In fact, several studies have shown that antigen specific Tregs are better at preventing diabetes in NOD mice than polyclonal Tregs (195-197).

\section{$\underline{\text { CD103 }}$}

The integrin $\alpha_{E} \beta_{7}(\mathrm{CD} 103)$ is a type I transmembrane protein expressed primarily on mucosal lymphocytes (198). The only known ligand for CD103 is E-cadherin, which is expressed primarily on epithelial cells in the gut, skin, and thymus (199-202). Ecadherin is expressed on medullary thymic epithelial cells, which are cells that have been shown to be necessary for Treg development in the thymus $(202,203)$. E-cadherin is upregulated during inflammation (204). There is also some evidence for E-cadherinindependent binding of CD103 to another unknown ligand expressed on human intestinal microvascular endothelial cells (205) and in oral epithelial and epidermal tissues (206).

CD103 expression identifies a very potent subset of regulatory $\mathrm{T}$ cells in both mice and humans (207-209). CD103 ${ }^{+}$Tregs have a memory/effector phenotype (210) and the subset represents a small fraction of the peripheral $\mathrm{CD} 4^{+} \mathrm{CD} 25^{+}$Tregs. $\mathrm{CD} 103^{+}$Tregs 
are better suppressors in vitro and in vivo than $\mathrm{CD}_{103^{-}}$Tregs $(149,207,211)$. The increase in suppressive function does not appear to be due to increased IL-10 production by the $\mathrm{CD} 103^{+}$Treg subset, as $\mathrm{CD}_{103^{+}}{ }^{+}$regs from IL-10 knockout mice are as suppressive as $\mathrm{CD}_{103^{+}}$Tregs from wildtype mice (211). The expression of CD103 on Tregs has been shown to function in retention of these cells at sites of inflammation (212). In fact, $\mathrm{CD} 4{ }^{+} \mathrm{CD} 25^{+}$Tregs purified from $\mathrm{CD} 103$-deficient mice were less effective than wildtype $\mathrm{CD} 4^{+} \mathrm{CD} 25^{+}$Tregs at homing to and accumulating in sites of dermal inflammation in a mouse model of Leishmania major infection (212). It is thought that CD103 is induced and/or maintained at these sites of inflammation $(207,212)$ and $\mathrm{CD}_{103^{+}}$Tregs develop their increased suppressive function at sites of inflammation (213). $\mathrm{CD}_{103^{+}}$Tregs that lack E/P-selectin ligands (i.e., cannot migrate to sites of inflammation) were not as suppressive in a DTH model as wildtype $\mathrm{CD} 103^{+}$Tregs that were able to enter inflamed sites, though they expressed similar levels of Foxp3 and other markers such as CD62L (213). Effector/memory $\mathrm{CD} 103^{+}$Tregs, that have presumably been activated in vivo, can spontaneously (i.e., without additional activation) suppress $\mathrm{CD} 4^{+} \mathrm{CD} 25^{-}$effector $\mathrm{T}$ cells in an in vitro suppression assay (189).

The homing and maintenance of lymphocytes to specific locations, whether to lymphoid organs or to non-lymphoid tissues, is very important for proper immune function (214). $\mathrm{CD} 4^{+} \mathrm{CD} 25^{+} \mathrm{CD} 103^{+}$Tregs have an "inflammation-seeking" phenotype, expressing adhesion molecules like ICOS, P-selectin ligand, and E-selectin ligand and chemokine receptors that promote migration towards inflammatory chemokines such as CXCL9, CCL17, and CCL20 (210). Expression of CD103 allows T cells to form filopodia and move towards E-cadherin (215). Migration to sites of inflammation is 
necessary to suppress inflammatory reactions in vivo, but not to control the induction phase of an immune response in the lymph nodes (213). In fact, in bone marrow chimera studies where scurfy (Foxp3-deficient) bone marrow and CCR $4^{-/-}$bone marrow were transferred into Rag $1^{-/-}$recipients, the lack of CCR 4 on $\mathrm{CD} 103^{+}$Tregs prevented migration to the skin and resulted in severe inflammatory disease in the skin (216).

The $\mathrm{CD} 103^{+}$subset of Tregs is important in disease settings. In an adoptive transfer model of wasting disease, $\mathrm{CD} 4^{+} \mathrm{CD} 25^{+} \mathrm{CD} 103^{+}$Tregs, but not $\mathrm{CD}^{+} \mathrm{CD} 25^{+} \mathrm{CD} 03^{-}$Tregs are able to prevent wasting disease (211). CD103-deficient $\left(\alpha_{\mathrm{E}}^{-/ /}\right)$mice have reduced T lymphocyte numbers in gut and vaginal mucosal tissue (217). CD103-deficient mice develop inflammatory skin lesions spontaneously, and transfer of splenocytes from CD103-deficient, but not wildtype, mice into scid/scid mice also induces skin inflammation (218). Donor $\mathrm{CD}_{103^{+}}$Tregs from $\mathrm{DBA} / 2$ mice transferred into recipient BALB/c mice with chronic graft-versus-host disease (GVHD) help reverse symptoms by trafficking to GVHD target tissues and suppressing donor $\mathrm{CD}^{+} \mathrm{T}$ cell proliferation (219).

There are other cells that express CD103. A small percentage of circulating $\mathrm{CD} 8^{+}$ cells express CD103, produce IL-10, and have suppressive function in a cell-cell contact dependent manner in vitro (220). The $\mathrm{CD}^{+} \mathrm{CD} 103^{+}$Tregs can be expanded by exposure to alloantigen in vitro (220). These $\mathrm{CD} 8^{+} \mathrm{CD} 103^{+}$Tregs are also involved in a model of induced tolerance referred to as anterior chamber-associated immune deviation (ACAID) (221). Cytotoxic $\mathrm{CD}^{+} \mathrm{T}$ cells have also been shown to express $\mathrm{CD} 103$ (222-224). These $\mathrm{CD}^{+} \mathrm{CD} 103^{+}$cytotoxic $\mathrm{T}$ cells bind target E-cadherin expressing cells and cause them to apoptose and have been associated with tissue destruction of exocrine glands in Sjogren's 
syndrome, tissue destruction of lungs in a lung transplant model and tumor regression in a brain tumor model (222-224). CD103 has also been shown to be important in the development of $\mathrm{CD} 4^{-} \mathrm{CD}^{+}$thymocytes (225). CD103 is a target of Runx3, a transcription factor responsible for the processes that downregulate $\mathrm{CD} 4$ on $\mathrm{CD} 4^{+} \mathrm{CD} 8^{+}$thymocytes (225).

A subset of DCs also expresses CD103. They are found primarily in the gut, but a small subset can be found in the mesenteric lymph node (226). These $\mathrm{CD} 103^{+} \mathrm{DCs}$ from both gut and mesenteric lymph nodes can induce a gut-homing phenotype $\left(\mathrm{CCR}^{+} \alpha_{4} \beta_{7}{ }^{+}\right)$ in T lymphocytes (226). CD103 expression on gut-associated DCs is necessary for protection against a $\mathrm{T}$ cell adoptive transfer model of colitis $(227) . \mathrm{CD} 103^{+} \mathrm{DCs}$ are thought to mediate conversion of $\mathrm{CD} 4^{+} \mathrm{CD} 25^{-}$effector cells to $\mathrm{CD} 4^{+} \mathrm{CD} 25^{+}$Tregs via secretion of retinoic acid in the gut $(228,229)$. There is also a subset of $\mathrm{CD}_{103^{+}} \mathrm{DCs}$ in the skin that is able to effectively cross-present viral and self antigens (230). An invariant NKT cell subset, found in the peripheral lymph nodes and in skin, produces IL-17 and also expresses $\mathrm{CD} 103$ (231). So, while $\mathrm{CD} 103$ is expressed on a subset of $\mathrm{CD} 4{ }^{+} \mathrm{CD} 25^{+}$ Tregs, it is also expressed on a variety of other cell types in the immune system. Thus, one can reason that $\mathrm{CD} 103$ itself does not confer regulatory function, but perhaps it is its role in retention and homing to specific tissues that gives $\mathrm{CD}_{103^{+}}$Tregs their increased suppressive function.

CD103 can be induced by TGF- $\beta$ (232). For most integrins, a proximal promoter confers cytokine responsiveness, but for $\mathrm{CD} 103$, responsiveness is likely dependent on more distant control elements (233). One of these distant control elements may be the transcription factor Foxp3 because when $\mathrm{CD} 4^{+} \mathrm{CD} 25^{-} \mathrm{T}$ cells are transduced with Foxp3, 
they express $\mathrm{CD} 103$ (129). Other factors control the size of the $\mathrm{CD} 4^{+} \mathrm{CD} 25^{+} \mathrm{CD} 103^{+}$ population of Tregs. CD47, whose ligands thrombospondin 1 (TSP-1) and SIRP- $\alpha$ are involved in inhibition of $\mathrm{DC}$ and $\mathrm{T}$ cell function, is important in controlling $\mathrm{CD} 103^{+}$Treg homeostatic proliferation (234), as seen in CD47 knockout mice, which have increased percentages of these Tregs due to unrestrained proliferation (235).

\section{$\underline{\text { Strain Differences }}$}

Genetically different strains of mice can have dramatically different immune systems, and thus, different immune responses to infection and autoimmune disease. Non-autoimmune prone strains of mice have dsDNA-specific autoreactive B cells that remain inactive, while lupus-prone BWF1 mice have autoreactive B cells that produce high titers of anti-dsDNA antibodies (236). B cells from mice with a high affinity antiDNA $\mathrm{H}$ chain transgene on a C57BL/6 background produce anti-dsDNA antibodies while B cells from mice with this same transgene on a BALB/c background do not produce anti-dsDNA antibodies (237). This transgene on the C57BL/6 background promotes repertoire shifting to $\mathrm{L}$ chains, which allow better DNA binding (237), illustrating the impact genetic background can have on disease promoting symptoms.

Some strains of mice are skewed to a more $\mathrm{T}_{\mathrm{H}} 1$ or $\mathrm{T}_{\mathrm{H}} 2$ response (238). These differences can cause some mouse strains to be more susceptible to different types of infections (239-241) and autoimmune diseases (242-245). BALB/c mice, for example, have an immune system skewed towards a $\mathrm{T}_{\mathrm{H}} 2$ response (238), and are more susceptible to Mycobacterium avium infection, in which IL-10 has been shown to augment disease, than C57BL/6 mice, which have an immune system skewed more towards a $T_{H} 1$ response 
(241). Mice on a BALB/c background are less susceptible to Pseudomonas aeruginosa corneal infection than mice on a C57BL/6 background, indicating that a $\mathrm{T}_{\mathrm{H}} 1$ skewed immune response renders mice more susceptible to this disease (239).

Strain differences impact autoimmune disease susceptibility. In a mouse model of experimental autoimmune uveitis (EAU) susceptible strains of mice had a $T_{H} 1$ immune response, producing high levels of IFN- $\gamma$, IL-12, and IgG2a antibodies (242). Female SJL mice develop more severe EAE and pristane-induced lupus than age-matched males, hypothesized to be due to enhanced $\mathrm{T}_{\mathrm{H}} 2$ cytokine production in females compared to males, however, C57BL/6 mice do not show this female bias for EAE (245). Another group found differences in disease severity and progression between SJL mice from 4 different commercial vendors (246). They found that the strains had variation in gene copy numbers of inflammation-associated Naipl (Naipl mRNA was detected in SJL brain tissue and in a neuronal cell line), and that these differences correlated with the development of either chronic or relapsing remitting disease patterns (246). Pre-diabetic NOD mice, a model of type 1 diabetes, had higher percentages of B cells, an important cell type in diabetes development, in their thymi than other non-diabetic strains (244). Strain differences in susceptibility to Grave's hyperthyroidism have been used to find candidate genes (associated with the immunoglobulin heavy chain variable region) responsible for the break in tolerance and the production of thyroid stimulating antibodies (247-251). Knockout of Fc $\gamma \mathrm{RIIB}$ on a C57BL/6 background results in lupus-like disease, while FcyRIIB knockout on a BALB/c background does not result in disease (252). This is due to the presence of a lupus-suppressor gene, $\operatorname{sbb} 2(a)$, which restricts the production of pathogenic IgG antibody isotypes in BALB/c mice (253). 
Regulatory $\mathrm{T}$ cells play an important role in controlling autoimmune disease (123, 124). Variation in Treg populations of genetically different strains of mice may play a role in their susceptibility to autoimmune diseases. Howard and colleagues have reported that $\mathrm{BALB} / \mathrm{c}$ mice have significantly higher percentages of $\mathrm{CD} 4^{+} \mathrm{CD} 25^{+}$Tregs in the thymus and peripheral lymphoid organs than C57BL/6 mice, although both BALB/c and $\mathrm{C} 57 \mathrm{BL} / 6 \mathrm{CD} 4^{+} \mathrm{CD} 25^{+}$cells express similar levels of other regulatory markers like CD45RB, CD103, GITR, CTLA-4, and Foxp3 $(254,255)$. Interestingly, they also found that $\mathrm{CD} 4^{+} \mathrm{CD} 25^{-}$responder cells from $\mathrm{C} 57 \mathrm{BL} / 6$ mice are more resistant to suppression than $\mathrm{BALB} / \mathrm{c}$ responder cells by $\mathrm{CD} 4^{+} \mathrm{CD} 25^{+}$Tregs from both $\mathrm{C} 57 \mathrm{BL} / 6$ and $\mathrm{BALB} / \mathrm{c}$ mice in an in vitro suppression assay (254). Although Mathis et al. found no significant differences in $\mathrm{CD} 4^{+} \mathrm{CD} 25^{+}$cell percentages in the thymus or periphery when comparing NOD mice to non-diabetic mice (244), a dramatically reduced TCR repertoire was seen in NOD Tregs when compared to C57BL/6 Tregs (256). Obviously, the size and quality of the immune response can vary dramatically between inbred strains of mice, and comparison between strains can be a very useful tool to discover susceptibility loci for a variety of autoimmune diseases.

Gender differences exist for many autoimmune diseases. Sex hormones impact the immune system and can be used to treat autoimmune disease. Androgens tend to be immunosuppressive, while estrogens tend to be immunoenhansive. Regulatory $\mathrm{T}$ cells are important components in controlling autoimmune disease. Regulatory Treg populations can vary between females and males and between different inbred strains of mice. With this in mind, we have investigated regulatory $\mathrm{T}$ cell populations in a mouse model of 
lupus, comparing percentages between female and male lupus-prone BWF1 mice and comparing BWF1 Treg populations to other autoimmune-prone and less autoimmuneprone strains of mice. 


\section{MATERIALS AND METHODS}

Mice.

Female C57BL/6, BALB/c, SJL, and (NZBxNZW)F1 (BWF1) mice were either purchased from The Jackson Laboratories (Bar Harbor, ME) or bred and maintained in our animal facility at the University of Louisville. Animals were maintained under the guidelines stipulated by the University of Louisville Institutional Animal Care and Use Committee.

\section{Antibodies and reagents.}

The following monoclonal antibodies were purchased from BD Pharmingen (CA): anti-CD4-PerCP, anti-CD8-APC, anti-CD25-APC, anti-CD25-PE, anti-CD25-PECy7, anti-CD103-FITC, anti-Ki67-PE, anti-CD62L-APC, and anti-CD3 (2C11). AntiFoxp3-PE and anti-Foxp3-APC were purchased from Ebioscience (CA).

\section{Flow cytometric analysis.}

Single cell suspensions of $2 \times 10^{6}$ lymph node, spleen, or thymus cells were incubated with $\mathrm{Fc}$ block for 15 minutes at $4^{\circ} \mathrm{C}$ and then labeled with appropriate monoclonal antibodies in staining buffer (DPBS, $1 \% \mathrm{FCS}, 0.1 \% \mathrm{NaNO}_{3}$ ) for 15 minutes at $4^{\circ} \mathrm{C}$ in the dark, washed twice, and fixed in $2 \%$ formalin. For intracellular staining, cells were fixed and permeabilized following manufacturer's instructions. Stained cells 
were collected and analyzed on a FACS caliber (BD Pharmingen) or an LSR (Beckon Dickinson).

\section{Cell purification.}

Spleen cells were purified using T cell enrichment columns (R\&D Systems). These purified $\mathrm{T}$ cells were pooled with unfractionated LN cells and applied to CD4 enrichment columns (R\&D Systems). For separation of $\mathrm{CD} 25^{+}$cells, enriched $\mathrm{CD} 4^{+} \mathrm{T}$ cells were then labeled with CD25-PE antibody. Following a 15 minute incubation at $4^{\circ} \mathrm{C}$ and wash with Miltenyi MACS buffer, cells were labeled with anti-PE beads (Miltenyi). Labeled $\mathrm{CD} 4^{+}$cells were then applied to an MS magnetic bead column and $\mathrm{CD} 4^{+} \mathrm{CD} 25^{-}$ and $\mathrm{CD} 4^{+} \mathrm{CD} 25^{+}$cells were collected. For cell sorting, cells were labeled appropriately and sorted by a high-speed cell sorter (FACS Vantage or FACS Aria, BD Biosciences, CA) to $>95 \%$ purity.

\section{In vitro suppression assay.}

The suppressive ability of magnetic bead purified $\mathrm{CD} 4{ }^{+} \mathrm{CD} 25^{+}$or sorted $\mathrm{CD} 4^{+} \mathrm{CD} 25^{+} \mathrm{CD} 103^{+}$cells was tested by culturing them with $\mathrm{CD}^{+} \mathrm{CD} 25^{-}$responder $\mathrm{T}$ cells at varying ratios in the presence of $1 \times 10^{5}$ irradiated spleen cells and $0.5 \mathrm{ug} / \mathrm{ml}$ antiCD3. Cells were cultured in super complete media (phenol red-free RPMI 1640, 10\% heat-inactivated charcoal filtered FCS, $2 \mathrm{mM}$ glutamine, $10 \mathrm{mM}$ Hepes, $100 \mathrm{U} / \mathrm{ml}$ penicillin G sodium, $100 \mathrm{ug} / \mathrm{ml}$ streptomycin sulfate, and $10^{-5} \mathrm{M} 2$-mercaptoethanol) for 4 days at $37^{\circ} \mathrm{C}$ in $5 \% \mathrm{CO}_{2}$. On Day 3 , the cells were pulsed with $\left[{ }^{3} \mathrm{H}\right]$ thymidine $(0.5 \mathrm{uCi})$ 
for 18 hours. On Day 4, cells were harvested and radioactivity read on a scintillation counter.

\section{Measurement of proteinuria.}

Urine from female and male BWF1 mice was tested for the presence of protein bimonthly starting at 20 weeks of age using Albustix ${ }^{\circledast}$ (Bayer). Urine was scored from 0 to 5,0 indicating no protein detected in urine, 1 indicating $30 \mathrm{mg} / \mathrm{dL}$ protein detected in urine, 2 indicating $100 \mathrm{mg} / \mathrm{dL}$ protein detected in urine, 3 indicating $300 \mathrm{mg} / \mathrm{dL}$ protein detected in urine, 4 indicating over $2000 \mathrm{mg} / \mathrm{dL}$ detected in urine, and 5 indicating death. A mouse was considered sick when it scored 3 or above on two consecutive test dates.

\section{Measurement of BrdU incorporation.}

Mice were injected i.p. with $1 \mathrm{mg}$ BrdU every 12 hours for 3 days. After 72 hours, mice were sacrificed and their organs harvested. Single cell suspensions were surface labeled as described above, then intracellularly labeled with anti-BrdU fluorescent antibody following manufacturer's instructions (BD Pharmingen).

\section{In vivo depletion of CD103.}

8-week-old female and male BWF1 mice were injected i.p. with 1mg anti-CD103 monoclonal antibody (M290, BioXCell) or control IgG2a. These mice were treated twice a week with $0.5 \mathrm{mg}$ anti-CD103 antibody or control IgG2a from 8-12 weeks of age. Mice were then treated with a $0.5 \mathrm{mg}$ maintenance dose of anti-CD103 antibody or control 
$\operatorname{IgG} 2 \mathrm{a}$ once every 2 weeks from 12-20 weeks of age. Urine was tested every week for the presence of protein starting at 8 weeks of age.

\section{Statistical analysis.}

Data were subjected to analysis by student's $t$ test or ANOVA and the TukeyDramer multiple comparisons test. All experiments were performed at least two times, and most performed at least 5 times with similar results. A p-value $\leq 0.05$ is considered significant. ${ }^{*}$ indicates $\mathrm{p}<0.05,{ }^{* *}$ indicates $\mathrm{p}<0.005$, and ${ }^{* * *}$ indicates $\mathrm{p}<0.0005$. 


\section{RESULTS}

\section{SPECIFIC AIM I}

\section{Assessing regulatory $\mathbf{T}$ cell populations in young autoimmune-prone and less- autoimmune-prone strains of mice.}

The $\mathrm{CD} 4^{+} \mathrm{CD} 25^{+}$Foxp $3^{+}$cells are important regulators of the immune response, and are particularly important for the control of autoreactive cells and the prevention of autoimmune diseases (123). A large number of studies that evaluate the number and function of $\mathrm{CD} 4^{+} \mathrm{CD} 25^{+} \mathrm{Foxp} 3^{+}$regulatory cells have been conducted in both humans and mice that develop autoimmune/inflammatory diseases, including systemic lupus erythematosus, multiple sclerosis and type 1 diabetes, but the results have been inconclusive, i.e., some have found defects in numbers and/or function whereas others have not $(160,162-169,172,173,244)$. In the current study, we compared the numbers and function of regulatory $\mathrm{T}$ cells from four different strains of mice that have varying predispositions to developing autoimmune diseases, including the (NZBxNZW)F1 (BWF1) and SJL strains which tend to be autoimmune disease-prone and the BALB/c and C57BL/6 strains which are more autoimmune disease-resistant to determine whether differences in regulatory $\mathrm{T}$ cell number or function correlated with differences in susceptibility to disease. 


\section{$\mathrm{CD4}^{+} \mathrm{CD25}^{+}$regulatory cells from young female $\mathrm{C57BL/6,} \mathrm{BALB/c,} \mathrm{SJL} \mathrm{and} \mathrm{BWF1}$ mice function similarly in an in vitro suppression assay.}

The $\mathrm{CD} 4^{+} \mathrm{CD} 25^{+}$cells are the best studied of the regulatory T cells (123). Since their "discovery" in the mid-1990s, attention has focused on the relationship between $\mathrm{CD} 4^{+} \mathrm{CD} 25^{+}$regulatory cell function/numbers and pre-disposition/susceptibility to autoimmune diseases $(125,172-174,176,178,179)$. Female (NZBxNZW)F1 (BWF1) mice spontaneously develop systemic lupus erythematosus (SLE), and SJL mice are much more susceptible to induced autoimmune diseases than the C57BL/6 or BALB/c strains of mice $(66,67)$. For this reason, we compared the characteristics of Tregs in these four strains of mice. The first question we addressed was whether there were qualitative differences in Treg function, i.e., differences in the ability of these cells to suppress responder $\mathrm{T}$ cell proliferation in vitro, between the different strains of mice. Although the classic in vitro assay for Treg-mediated suppression of responder cell proliferation may not always reflect the ability of Treg populations to regulate autoreactive cells in vivo, it is a measure of inherent Treg function and a defect in this function, even in vitro, would very likely translate into a defect in function in vivo. In the following experiments, we tested Treg function using two variations of the classic in vitro assay for regulatory cell function. First, using a protocol that standardized all of the potential variables except for the Tregs themselves, we tested the ability of $\mathrm{CD} 4^{+} \mathrm{CD} 25^{+}$ cells from the various strains of mice to suppress the same $C D 4^{+} \mathrm{CD} 25^{-}$responder cell/APC combination. For these experiments, varying numbers of $\mathrm{CD} 4{ }^{+} \mathrm{CD} 25^{+}$cells from each of the four strains of mice were co-cultured with $\mathrm{C} 57 \mathrm{BL} / 6 \mathrm{CD} 4^{+} \mathrm{CD} 25^{-}$ responder cells stimulated by C57BL/6 irradiated splenocytes as antigen presenting cells 
(APC) and anti-CD3. We found that the Tregs from all four strains of mice suppressed proliferation of anti-CD3-activated C57BL/6 responder cells equally effectively (Figure 1A, 7A). Next, we tested the ability of $\mathrm{CD} 4^{+} \mathrm{CD} 25^{+}$cells from the various strains of mice to suppress their own $\mathrm{CD}^{+} \mathrm{CD} 25^{-}$responder cell/APC combination (i.e., $\mathrm{CD} 4^{+} \mathrm{CD} 25^{-}$ responders and $\mathrm{APC}$ that were syngeneic to the Tregs) in the presence of anti-CD3 antibody. As shown in Figure 1B, we found that $\mathrm{CD} 4^{+} \mathrm{CD} 25^{+}$cells from all four strains of mice were equally effective at suppressing proliferation of anti-CD3-activated syngeneic responder cells in vitro (Figure 1B, 7B). In summary, we found no consistently significant differences in the ability of $\mathrm{CD}^{+} \mathrm{CD} 25^{+}$Tregs from any of the four strains to suppress responder cell proliferation in vitro and we, therefore, concluded that there were no differences in inherent Treg function between the four strains of mice tested.

\section{BWF1 mice have very low percentages of peripheral $\mathrm{CD}^{+} \mathrm{Foxp}^{+}$cells by comparison to other strains of mice.}

In addition to issues with regulatory function by Tregs, another contributing factor to the predisposition of humans and particular strains of mice to autoimmune disease could be an imbalance between the effector $\mathrm{CD} 4$ and regulatory $\mathrm{T}$ cell populations. In the following experiments, we performed a quantitative analysis of Tregs in the four different strains of mice. $\mathrm{CD}^{+}$cells collected from lymph node (LN) and spleen from the four different strains, BWF1, SJL, C57BL/6 and BALB/c, of young female mice were evaluated for expression of the transcription factor, Foxp3, a hallmark of $\mathrm{CD} 4^{+} \mathrm{CD} 25^{+}$ regulatory cells. In general, BWF1 mice had by far the lowest percentages of 
$\mathrm{CD} 4^{+}$Foxp $3^{+}$cells (i.e., percentage of CD4 cells expressing Foxp3) among the 4 strains evaluated, and in $\mathrm{LN}$, had less than half the level found in C57BL/6 and BALB/c mice (Figure 2A). Although not quite as low, SJL mice also had low percentages of $\mathrm{CD}^{+}{ }^{+} \mathrm{Foxp}^{+}$cells in $\mathrm{LN}$ compared to BALB/c mice and C57BL/6, but fairly high percentages in spleen (Figure 2A). The patterns of percentages of $\mathrm{CD} 4^{+} \mathrm{CD} 25^{+}$cells (i.e., percentages of CD4 cells expressing CD25) in both the LN and spleen were very similar to those found for $\mathrm{CD}^{+} \mathrm{Foxp}^{+}$cells in all four strains (Figure 2C). The percentages of $\mathrm{CD} 4^{+} \mathrm{CD} 25^{+}$cells that expressed Foxp3 were very similar in all four strains of mice $(>90 \%$, data not shown), and the level of Foxp3 expression (as indicated by the mean fluorescence intensity, MFI) in $\mathrm{CD} 4^{+} \mathrm{CD} 25^{+} \mathrm{Foxp} 3^{+}$cells was also similar for all four strains of mice (Figure 2D). Taken together, these data indicated that the Foxp $3^{+}$Treg to effector (Foxp3 $3^{-}$CD4 cell ratio (i.e., as reflected by the percentages of $\mathrm{CD}^{+} \mathrm{Foxp}^{+}$ cells) in the peripheral lymphoid organs differs between strains and tends to be lower in autoimmune-prone mice.

The analysis described above evaluated percentages, but not numbers, of cells in the various populations. Analysis of the numbers is important because it can reveal whether it is relative decreases in the numbers of $\mathrm{CD}^{+} \mathrm{Foxp}^{+}$cells or increases in the $\mathrm{CD} 4^{+} \mathrm{Foxp} 3^{-}$cells that produce differences in the $\mathrm{CD}^{+}{ }^{+} \mathrm{Foxp} 3^{+}$to $\mathrm{CD}^{+}{ }^{+}$Foxp $3^{-}$ratios. We found that the SJL mice had the highest total numbers of all cells (Table 1) as well as $\mathrm{CD}^{+}$cells (Figure 6B) in both $\mathrm{LN}$ and spleen among the four strains evaluated. The SJL mice also had the highest numbers of both $\mathrm{CD}^{+} \mathrm{Foxp}^{+}$cells (>4-fold more; Figure 2B) in $\mathrm{LN}$ and spleen of all four strains. C57BL/6 and BWF1 mice tended to have the lowest numbers of $\mathrm{CD}^{+} \mathrm{Foxp}^{+}$cells (Figure 2B). Overall, the numbers of peripheral 
$\mathrm{CD}^{+}{ }^{+} \mathrm{Foxp} 3^{+}$, with the exception of SJL mice, did not vary dramatically between the strains, and we concluded that these lower numbers of $\mathrm{CD} 4^{+} \mathrm{Foxp} 3^{+}$cells could not account for the differences in percentages.

BWF1 and SJL mice have low percentages of peripheral $\mathrm{CD}^{+} \mathrm{CD}^{+} 5^{+} \mathrm{CD} 103^{+}$cells. A number of different markers have been associated with $\mathrm{CD} 4^{+} \mathrm{CD} 25^{+}$regulatory cell phenotype and function $(125,127,128,143-147,149,150)$, and variations in their expression could affect regulatory T cell function in vivo. The integrin, CD103 $\left(\alpha_{\mathrm{E}} \beta_{7}\right)$, is expressed on the surface of cells and is involved in retaining cells at sites of inflammation via interaction with its ligand, E-cadherin $(198,199,212)$. In the $\mathrm{CD}^{+} \mathrm{CD} 25^{+}$regulatory cell population, $\mathrm{CD} 103$ also identifies a highly potent subset that is thought to represent a memory/effector phenotype $(207,210)$. Because of the unique and potentially important disease-preventing properties of this population of Tregs, we compared the function and quantity of $\mathrm{CD} 4^{+} \mathrm{CD} 25^{+} \mathrm{CD} 103^{+}$cells between the four strains of mice. In the following experiments, the regulatory function of sorted $\mathrm{CD} 4^{+} \mathrm{CD} 25^{+} \mathrm{CD} 103^{+}$cells from the four strains of mice was evaluated using the in vitro assay described above in which varying numbers of $\mathrm{CD} 4^{+} \mathrm{CD} 25^{+} \mathrm{CD} 103^{+}$cells from the different strains were co-cultured with their own $\mathrm{CD}^{+} \mathrm{CD} 25^{-}$responder cell/APC combination (i.e., syngeneic $\mathrm{CD} 4^{+} \mathrm{CD} 25^{-}$ responders and $\mathrm{APC}$ ) in the presence of anti-CD3 antibody. As shown in Figure 3D, the $\mathrm{CD} 4^{+} \mathrm{CD} 25^{+} \mathrm{CD} 103^{+}$cells from all four strains of mice were able to suppress syngeneic responders to the same extent (Figure 3D, 7C). We also performed a quantitative analysis of $\mathrm{CD} 4^{+} \mathrm{CD} 25^{+} \mathrm{CD} 103^{+}$cells in the lymphoid organs of the four strains of mice. The $\mathrm{CD} 4{ }^{+} \mathrm{CD} 25^{+}$cells from LN and spleen of the four strains of mice were evaluated for 
expression of $\mathrm{CD} 103$. The percentages and numbers of $\mathrm{CD} 4^{+} \mathrm{CD} 25^{+} \mathrm{CD} 103^{+}$cells (i.e., percentage of $\mathrm{CD} 44^{+} \mathrm{CD} 25^{+}$cells that express $\mathrm{CD} 103$ ) were dramatically lower in the LN and spleen of BWF1 mice compared to the other three strains of mice (Figure 3A, 6C). The percentages of $\mathrm{CD} 4^{+} \mathrm{CD} 25^{+} \mathrm{CD} 103^{+}$cells were also quite low in the $\mathrm{LN}$ of SJL mice, although they were actually fairly high in the spleen (Figure $3 \mathrm{~A}$ ). On the other hand, the percentages of $\mathrm{CD} 4^{+} \mathrm{CD} 25^{+} \mathrm{CD} 103^{+}$cells in the spleen, but not $\mathrm{LN}$, of C57BL/6 mice were very low (Figure 3A). Interestingly, CD103 (MFI) expression in $\mathrm{CD}^{+} \mathrm{CD} 25^{+} \mathrm{CD} 103^{+}$cells from the LN was significantly and consistently lower in BWF 1 mice than the other three strains and was also lower in cells from the spleen of BWF1 than either $\mathrm{BALB} / \mathrm{c}$ or SJL mice (Figure 3B, 3C). There were no differences in the percentages of $\mathrm{CD} 4^{+} \mathrm{CD} 25^{+} \mathrm{CD} 103^{+}$cells that expressed Foxp3 (>90\%) between any of the four strains or in the expression (MFI) of Foxp3 by this population (data not shown). Taken together, these data indicated that the autoimmune-prone strains of mice tended to have lower percentages of $\mathrm{CD} 4^{+} \mathrm{CD} 25^{+} \mathrm{CD} 103^{+}$cells at least in the $\mathrm{LN}$, and in the case of BWF1 mice, lower expression of CD103.

\section{Neither thymic production nor proliferation rate appear to account for the differences in either $\mathrm{CD}^{+} \mathrm{Foxp}^{+}$cells or $\mathrm{CD}^{+} \mathrm{CD25}^{+} \mathrm{CD} 103^{+}$cells percentages in the periphery between strains.}

Several factors can influence the numbers/relative proportions of peripheral $\mathrm{T}$ cell populations, and these include thymic production of $\mathrm{T}$ cells and proliferation (nonantigen-induced) of peripheral $\mathrm{T}$ cell populations $(185,257)$. We first examined thymus glands from each of the four strains of mice. The BWF1 strain of mice had the highest 
thymic weights and total cell numbers in the thymus, (Table 1), but not numbers of $\mathrm{CD} 4^{+} \mathrm{CD} 8^{-}$cells (Figure 6B). The SJL mice had very high percentages and numbers of $\mathrm{CD}^{+} \mathrm{CD}^{-}$cells in the thymus (Figure 6A, 6B). Importantly, the percentages of $\mathrm{CD}^{+}{ }^{+} \mathrm{CD} 8{ }^{-} \mathrm{Foxp}^{+}$cells in the thymus were comparable in the BALB/c, SJL and BWF1 strains whereas C57BL/6 strain had low percentages (Figure 4A). The SJL mice had dramatically higher numbers of $\mathrm{CD}^{+} \mathrm{CD}^{-} \mathrm{Foxp}^{+}$cells in the thymus (Figure $2 \mathrm{~B}$ ) than the other strains of mice which is not surprising since as mentioned above, this strain also had considerably higher numbers of thymic CD4 cells than the other strains of mice. BWF1 had comparable or even higher numbers of $\mathrm{CD}^{+} \mathrm{CD}^{-} \mathrm{Foxp}^{+}$cells in the thymus than either $\mathrm{C} 57 \mathrm{BL} / 6$ or $\mathrm{BALB} / \mathrm{c}$ mice.

Most evidence suggests that CD103 is upregulated in Tregs after activation in the periphery hence the hypothesis that $\mathrm{CD} 4^{+} \mathrm{CD} 25^{+}$that express $\mathrm{CD} 103$ cells are effector and/or memory cells $(207,210,212)$. However, $\mathrm{CD} 4^{+} \mathrm{CD} 25^{+} \mathrm{CD} 103^{+}$cells can be found in the thymus and some evidence suggests that at least some of these cells may also be produced in the thymus (258). For this reason, we analyzed the thymus of the four different strains of mice for $\mathrm{CD} 4^{+} \mathrm{CD} 25^{+} \mathrm{CD} 103^{+}$cells. The $\mathrm{CD} 103^{+}$cells, albeit in small numbers, could be detected in the thymus, and $\mathrm{C} 57 \mathrm{BL} / 6$ mice had very low and $\mathrm{BALB} / \mathrm{c}$ mice very high percentages ( $>5$-fold higher than $\mathrm{C} 57 \mathrm{BL} / 6$ mice) of $\mathrm{CD} 4^{+} \mathrm{CD} 25^{+} \mathrm{CD} 103^{+}$ cells (Figure 4B). SJL mice had high numbers (Figure 6C) and moderately high percentages (Figure 4B; although still one-half of that found in BALB/c mice) of $\mathrm{CD}^{+} \mathrm{CD} 25^{+} \mathrm{CD} 103^{+}$cells in the thymus. From these data, we concluded that there appeared to be little relationship between the thymic production of $\mathrm{CD} 4^{+} \mathrm{Foxp} 3^{+}$cells and $\mathrm{CD} 4^{+} \mathrm{CD} 25^{+} \mathrm{CD} 103^{+}$cells, at least in terms of their relative percentages in the periphery. 
Furthermore, when we compared the proportion of $\mathrm{CD}^{+} \mathrm{Foxp}^{+}$cells in the thymus to that in the periphery, we found that the thymic to peripheral $\mathrm{CD} 4^{+} \mathrm{Foxp} 3^{+}$cell ratio in BWF1 was twice that of the other three strains (Figure 4C), suggesting that it is not likely to be the ability of the BWF1 thymus gland to produce $\mathrm{CD} 4^{+} \mathrm{Foxp} 3^{+}$cells that is an issue here.

$\mathrm{T}$ cells cycle, albeit slowly, in the absence of their cognate antigen in a nonlymphopenic environment, and differences in proliferation rate of either the Tregs or effector cells could affect the Treg to effector $T$ cell balance (i.e., the Treg percentages) in the periphery. To determine whether there were differences in the proliferation rate of T cell populations between the four strains of mice, $\mathrm{LN}$ and spleen cells from BWF1, C57BL/6, BALB/c, and SJL mice were labeled for CD4, CD25, Foxp3, CD103 and in order to identify actively proliferating cells, Ki67. The SJL mice tended to have greater percentages of both $\mathrm{CD}^{+}{ }^{+} \mathrm{Foxp}^{+}$cells and $\mathrm{CD} 4^{+} \mathrm{CD} 25^{+} \mathrm{CD} 103^{+}$cells that expressed Ki67 (i.e., cells that were in the active phases of the cell cycle) compared to the other three strains which all had comparable levels of proliferating cells (Figure 5A, 5C). The BALB/c, SJL and BWF1 mice had comparable percentages of $\mathrm{CD}^{+} \mathrm{Foxp} 3^{-}$cells that were proliferating whereas $\mathrm{C} 57 \mathrm{BL} / 6$ tended to have higher percentages of proliferating $\mathrm{CD}^{+}{ }^{+}$Foxp $3{ }^{-}$cells (Figure 5B). To further examine the relationship between proliferating Tregs ( $\mathrm{CD} 4^{+} \mathrm{Foxp}^{+}$cells) and effector $\mathrm{CD} 4$ cells $\left(\mathrm{CD}^{+}{ }^{+} \mathrm{Foxp} 3^{-}\right.$cells), we analyzed the ratio between these two populations. As shown in Figure 5D, the proliferating Treg to effector CD4 cell ratio tended to be somewhat higher in SJL mice compared to the other strains, and the differences in ratios did not correlate with differences in percentages of $\mathrm{CD} 4^{+} \mathrm{Foxp}^{+}$cells in peripheral lymphoid organs. From these data, we concluded that 
there did not appear to be any type of direct correlation or association between differences in effector or Treg CD4 cell proliferation and the percentages of $\mathrm{CD}^{+} \mathrm{Foxp}^{+}$ cells in the periphery.

\section{Summary}

In this study we compared regulatory $\mathrm{T}$ cell percentages and function between young females from four strains of mice. We found decreased percentages but not a decrease in inherent suppressive function of Tregs in BWF1 mice compared to the other strains. Differences in thymic production and homeostatic proliferation could not account for the differences in peripheral percentages seen between four strains of mice. These data suggest that reduced percentages of both $\mathrm{CD} 4^{+} \mathrm{Foxp} 3^{+}$and memory/effector $\mathrm{CD}^{+} \mathrm{CD} 25^{+} \mathrm{CD} 103^{+}$subsets of Tregs in the periphery, and not decreased function, at least in vitro, appear to be an important difference between lupus-prone BWF1 mice and other autoimmune-prone SJL mice and less-autoimmune prone C57BL/6 and BALB/c mice. 
A

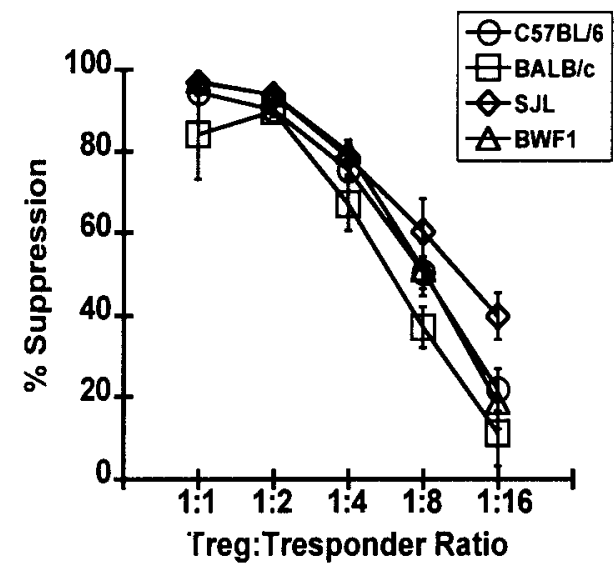

B

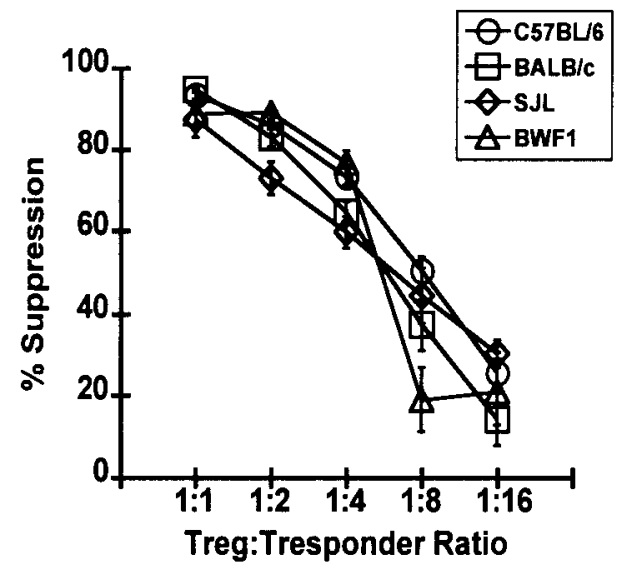

Figure 1. Regulatory function of $\mathrm{CD} 4^{+} \mathrm{CD} 25^{+}$cells from four strains of mice.

$\mathrm{CD} 4^{+} \mathrm{CD} 25^{+}$cells were purified from 9-week-old female C57BL/6, BALB/c, SJL, and BWF1 mice and varying numbers co-cultured with a constant number of (A) C57BL/6 $\mathrm{CD} 4^{+} \mathrm{CD} 25^{-}$responder cells and APC (irradiated spleen cells) or (B) syngeneic $\mathrm{CD} 4^{+} \mathrm{CD} 25^{-}$responder cells and $\mathrm{APC}$ and soluble anti-CD3 antibody. \% suppression of positive control (responder cells alone) was calculated and the mean \pm SEM presented for 4-5 separate experiments. 
A
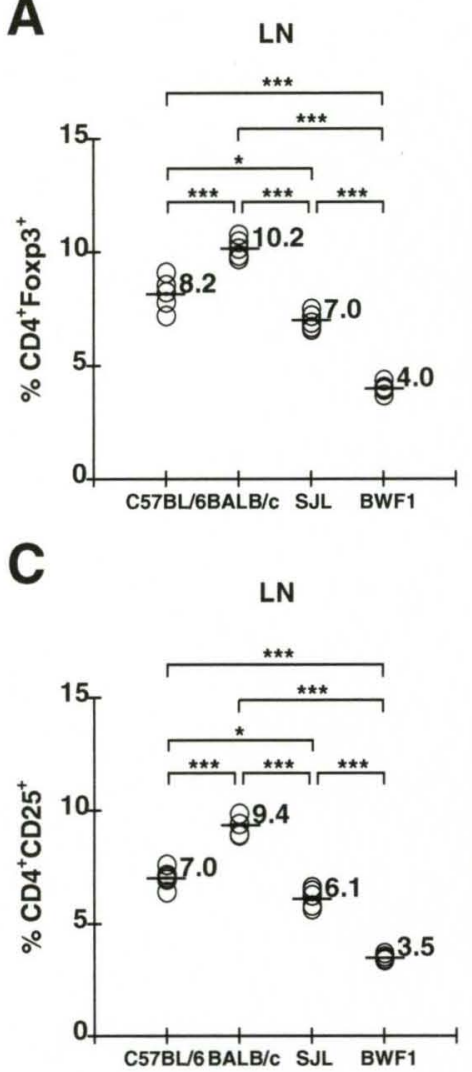

Spleen
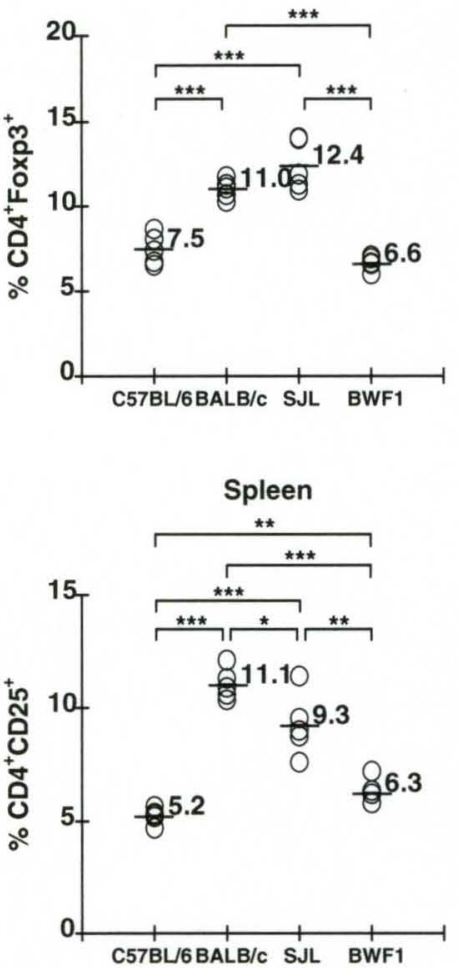

B

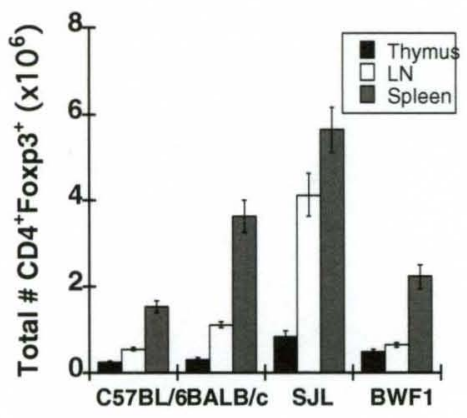

D

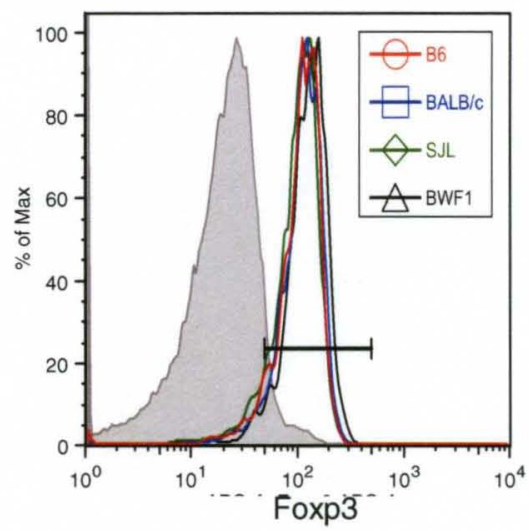

Figure 2. Percentages and numbers of $\mathrm{CD}^{+}{ }^{+}$Foxp $3^{+}$cells in four strains of mice. Cells from lymph nodes (LN), spleen and thymus of 9-week-old female C57BL/6 (B6), BALB/c, SJL and (NZBxNZW)F1 (BWF1) mice were labeled with anti-CD4, anti-CD25, and anti-Foxp3 antibodies and analyzed by FACS ${ }^{\circledR}$. (A) Labeled CD4 ${ }^{+}$cells were gated and analyzed for the percentages of cells expressing Foxp3 in LN and spleen. (B) The total numbers of $\mathrm{CD}^{+} \mathrm{Foxp}^{+}$cells in lymph nodes, spleen, and thymus $(\mathrm{n}=16)$ are shown. (C) Labeled CD4 ${ }^{+} \mathrm{T}$ cells were gated and analyzed for the percentages of cells expressing CD25 in LN and spleen. (D) Histogram of Foxp3 expression in $\mathrm{CD}^{+} \mathrm{CD} 25^{+}$ 
cells from a representative sample of $\mathrm{LN}$ cells from B6, BALB/c, SJL, and BWF1 mice. (A, C) A representative experiment of 5 performed is shown. Each symbol represents an individual animal. Statistical differences were analyzed using a student's $t$ test or ANOVA and the Tukey-Kramer multiple comparisons test. ${ }^{*} \mathrm{p}<0.05,{ }^{* *} \mathrm{p}<0.005$, and $* * * \mathrm{p}<0.0005$. 
A
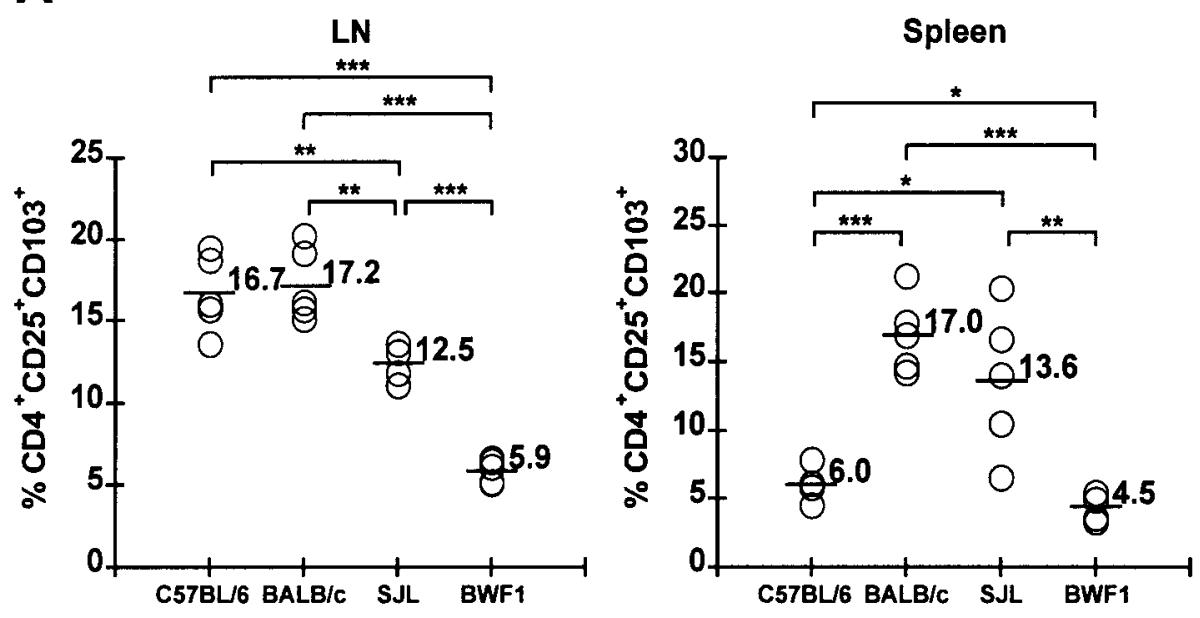

B
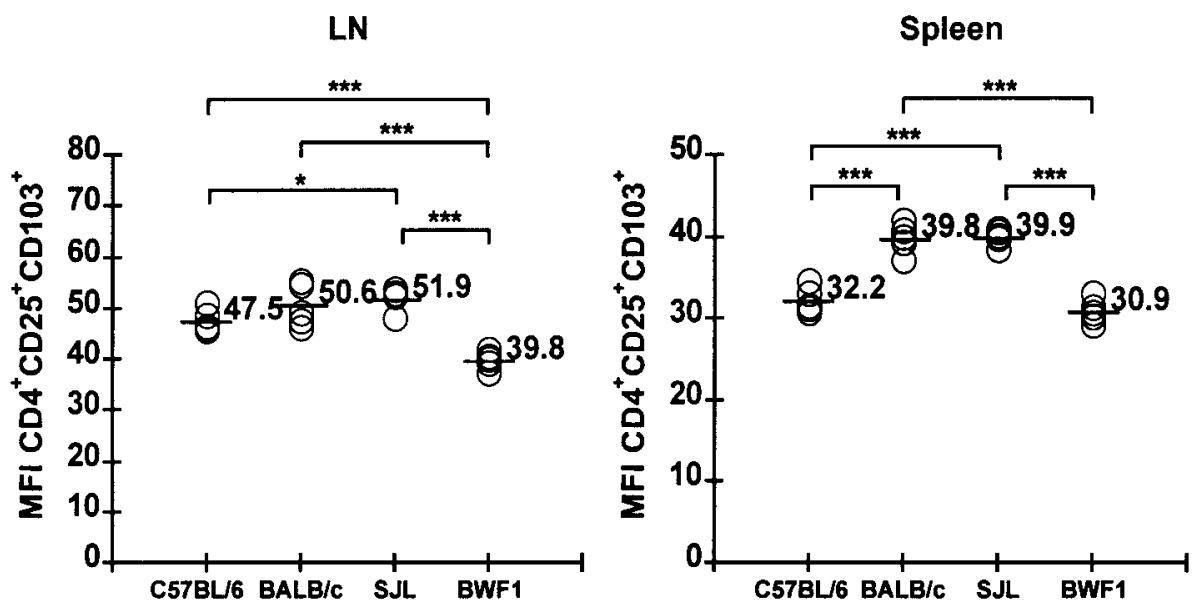
C
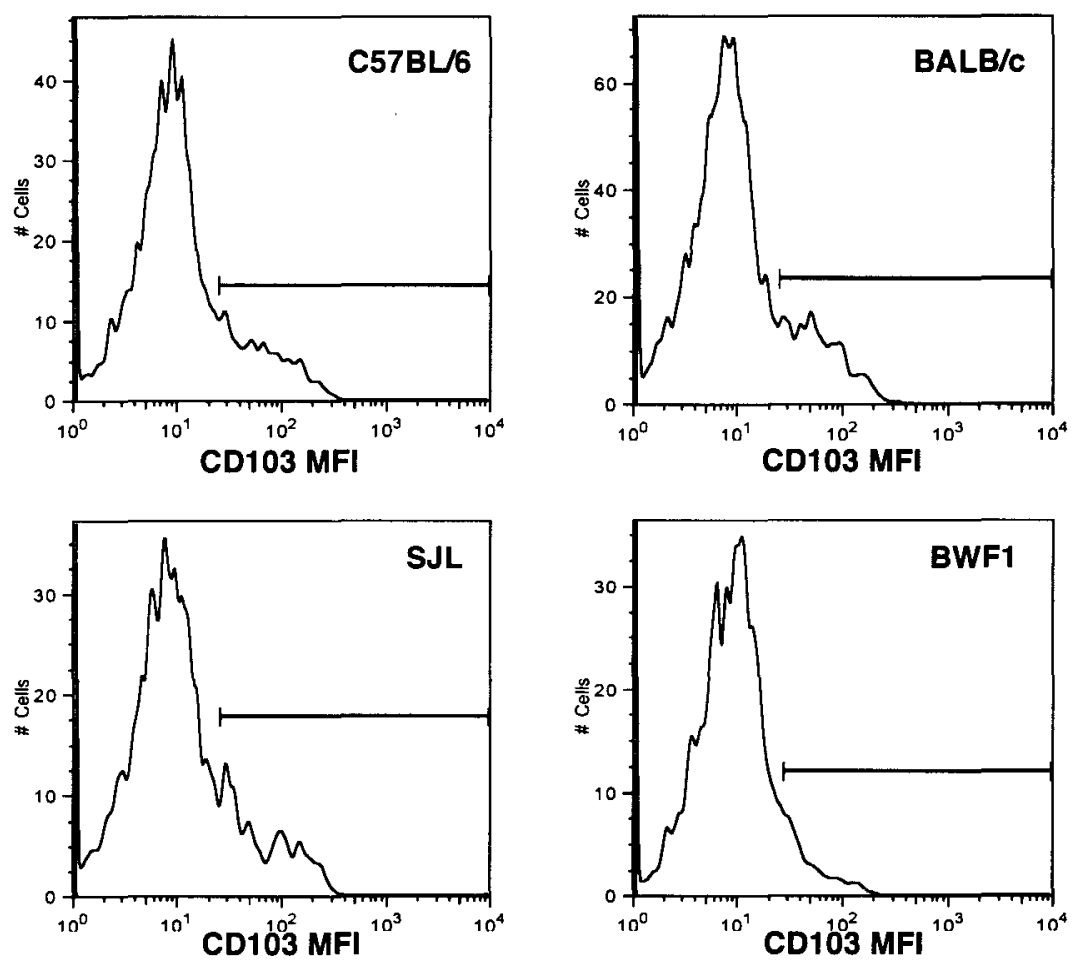

D

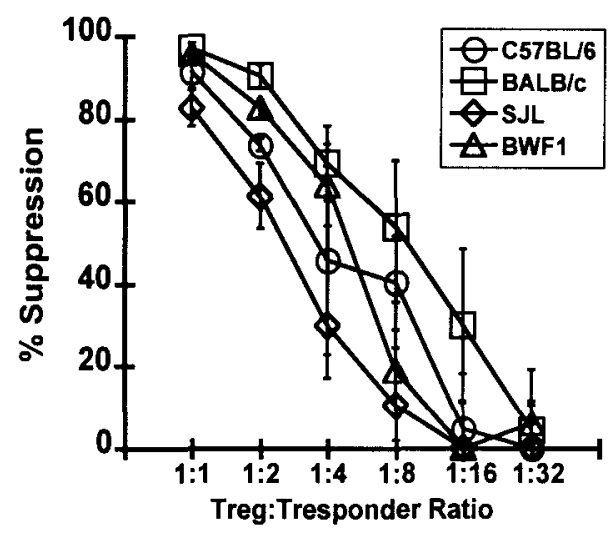

Figure 3. Regulatory function and percentages of $\mathrm{CD} 4^{+} \mathrm{CD} 25^{+} \mathrm{CD} 103^{+}$cells in the periphery of four strains of mice. Cells from lymph nodes (LN) and spleen of 9-week-old female C57BL/6 (B6), BALB/c, SJL and (NZBxNZW)F1 (BWF1) mice were labeled 
with anti-CD4, anti-CD25, and anti-CD103 antibodies and analyzed by FACS ${ }^{\circledast}$. (A) Labeled $\mathrm{CD} 4^{+} \mathrm{CD} 25^{+}$cells were gated and analyzed for the percentages of cells expressing CD103 in LN and spleen. (B) Labeled $\mathrm{CD} 4^{+} \mathrm{CD} 25^{+}$cells were gated and analyzed for the per cell expression of CD103 in LN and spleen. (C) Histogram of $\mathrm{CD} 103$ expression in $\mathrm{CD}^{+} \mathrm{CD} 25^{+}$cells from a representative sample of $\mathrm{LN}$ cells from B6, BALB/c, SJL and BWF1 mice. (A, B) A representative experiment of 5 performed is shown. Each symbol represents an individual animal. (D) $\mathrm{CD}^{+} \mathrm{CD} 25^{+} \mathrm{CD} 103^{+}$cells were purified from 9-week-old female C57BL/6, BALB/c, SJL, and BWF1 mice and sorted and varying numbers co-cultured with a constant number of syngeneic $\mathrm{CD}^{+} \mathrm{CD} 25^{-}$responder cells and $\mathrm{APC}$ and soluble anti-CD3 antibody. \% suppression of positive control (responder cells alone) was calculated and the mean \pm SEM presented for 4-5 separate experiments. Statistical differences were analyzed using a student's $t$ test or ANOVA and the Tukey-Kramer multiple comparisons test. ${ }^{*} \mathrm{p}<0.05,{ }^{* *} \mathrm{p}<0.005$, and ${ }^{* * *} \mathrm{p}<0.0005$. 
A

Thymus

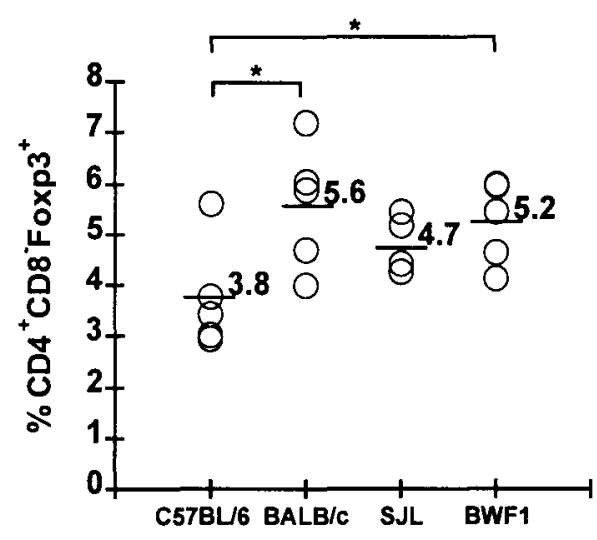

C

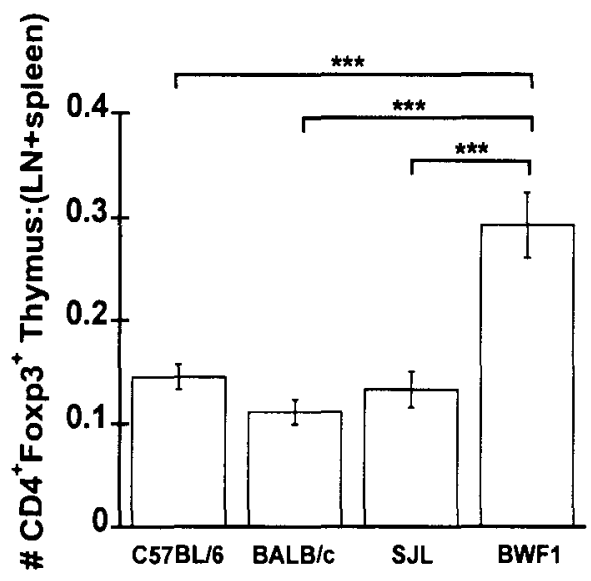

B
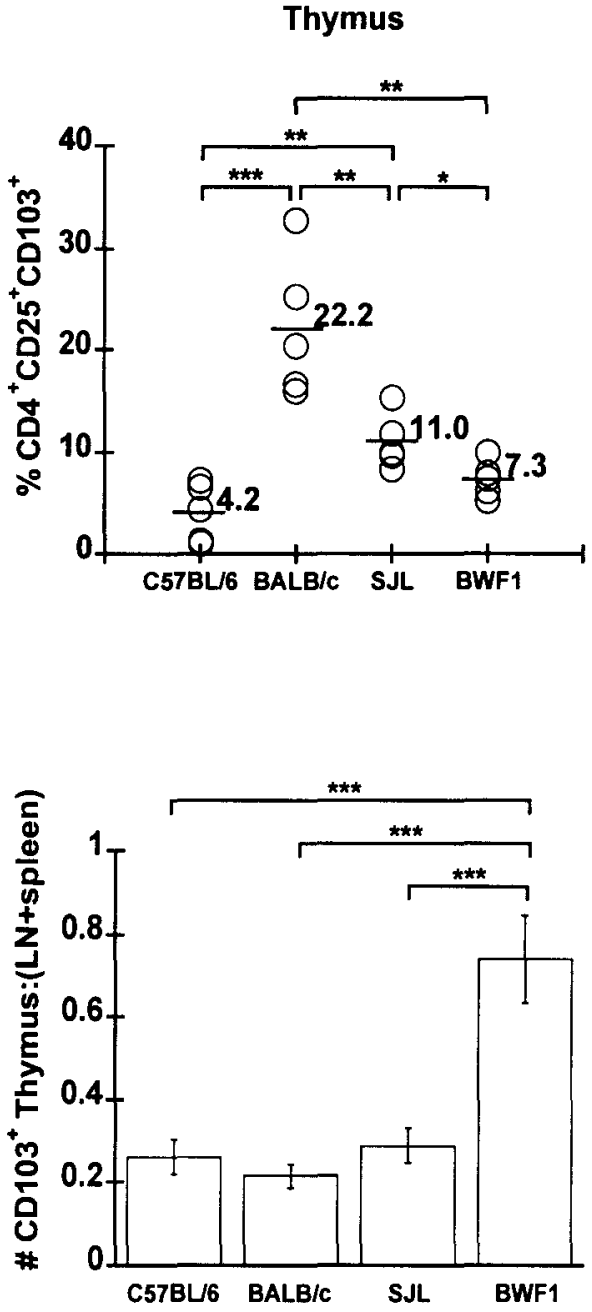

Figure 4. Percentages of $\mathrm{CD} 4^{+} \mathrm{Foxp} 3^{+}$and $\mathrm{CD} 4^{+} \mathrm{CD} 25^{+} \mathrm{CD} 103^{+}$cells in thymus of four strains of mice. Cells from thymus of 9-week-old female C57BL/6 (B6), BALB/c, SJL and (NZBxNZW)F1 (BWF1) mice were labeled with anti-CD4, anti-CD8, anti-CD25, anti-CD103 and anti-Foxp3 antibodies and analyzed by FACS ${ }^{\circledR}$. (A) Labeled CD4 ${ }^{+}$CD8 cells were gated and analyzed for the percentages of cells expressing Foxp3 in thymus. (B) Labeled $\mathrm{CD}^{+} \mathrm{CD} 8{ }^{-} \mathrm{CD} 25^{+}$cells were gated and analyzed for the percentages of cells expressing CD103 in thymus. (C) Ratio of numbers of $\mathrm{CD} 4^{+} \mathrm{CD} 8{ }^{-} \mathrm{Foxp} 3^{+}$cells in the 
thymus to numbers of $\mathrm{CD} 4^{+} \mathrm{Foxp}^{+}$cells in the periphery (i.e., $\mathrm{LN}$ and spleen). (A, B) A representative experiment of 5 performed is shown. Each symbol represents an individual animal. Statistical differences were analyzed using a student's $t$ test or ANOVA and the Tukey-Kramer multiple comparisons test. ${ }^{*} \mathrm{p}<0.05,{ }^{* *} \mathrm{p}<0.005$, and ${ }^{* * *} \mathrm{p}<0.0005$. 
A
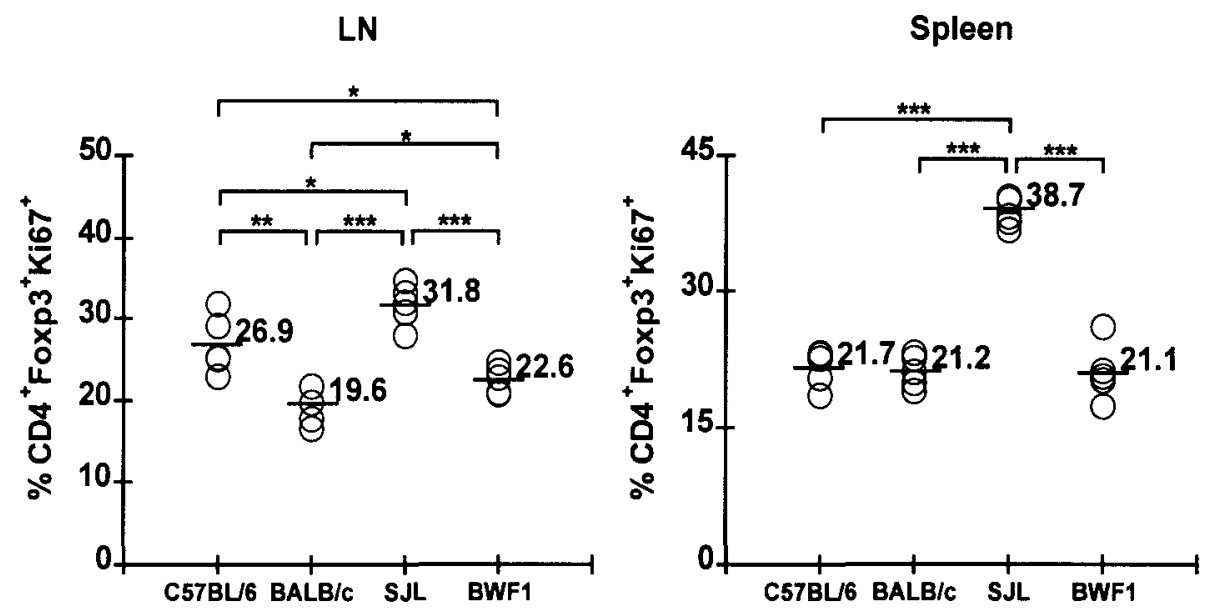

B
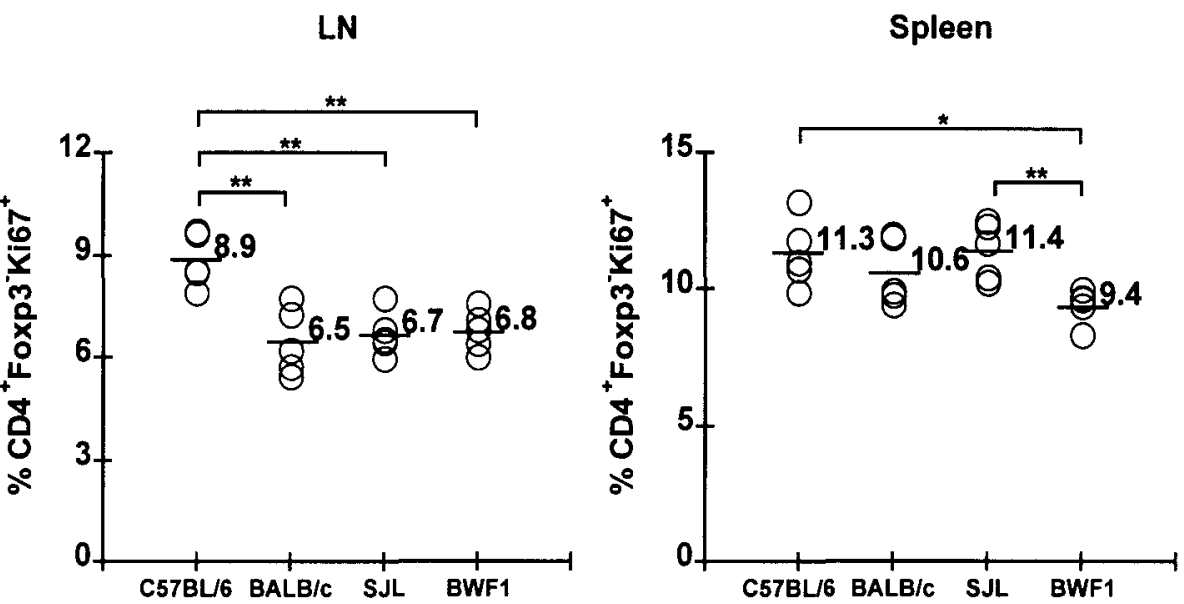

C
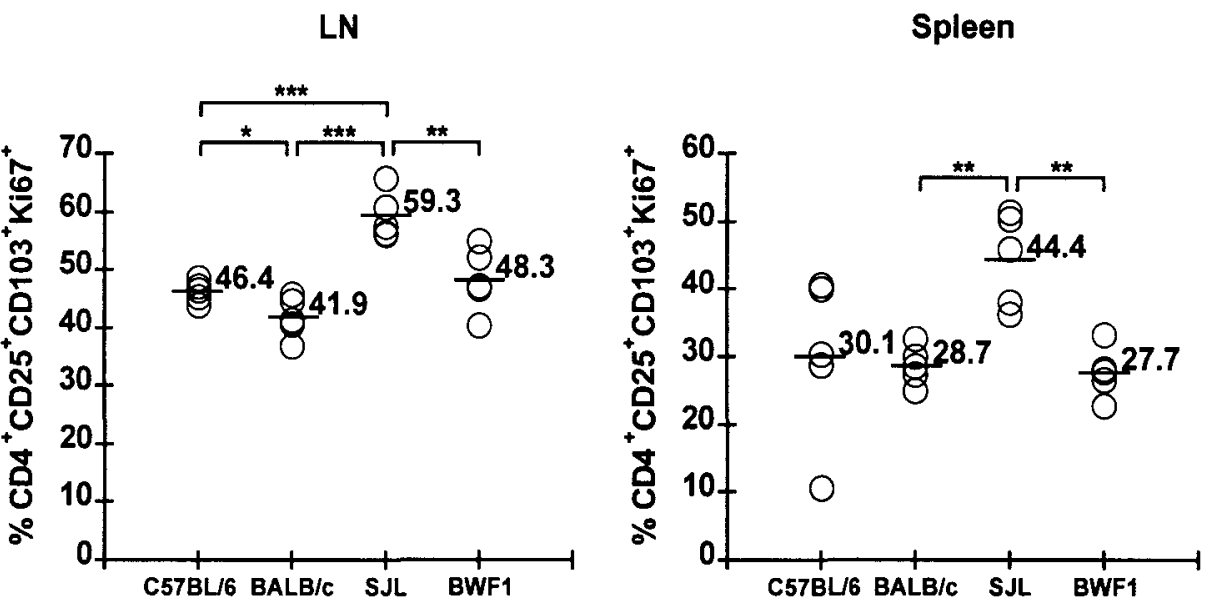

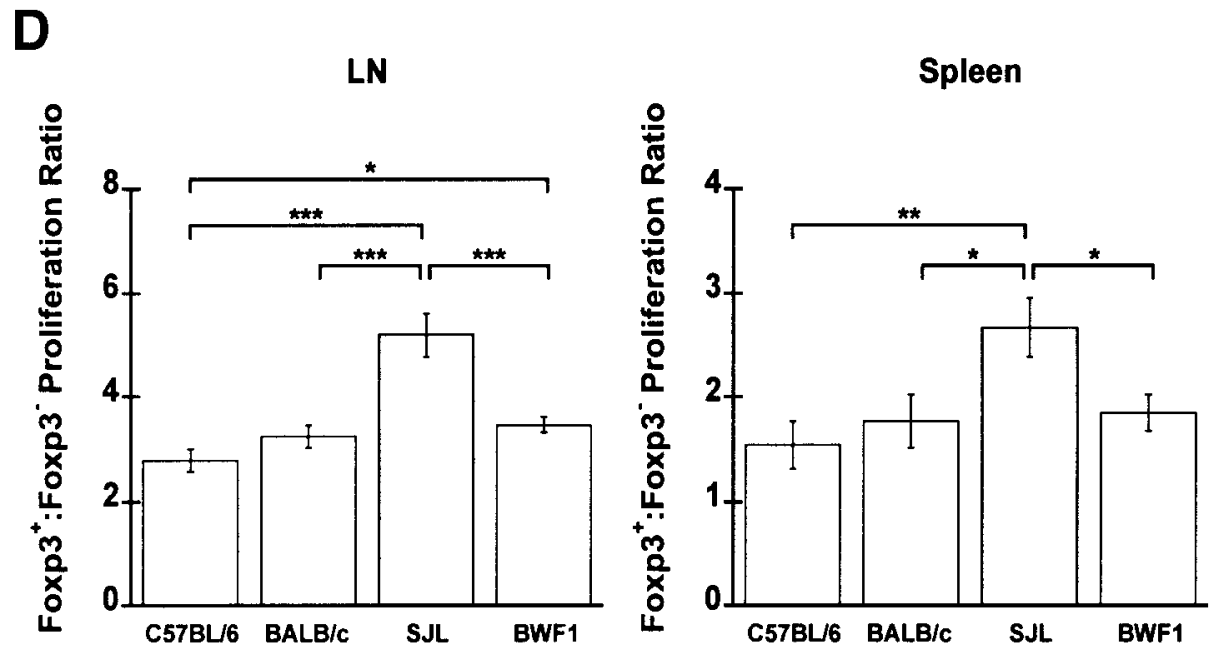

Figure 5. Percentages of proliferating $\mathrm{CD} 4^{+} \mathrm{Foxp} 3^{+}, \mathrm{CD} 4^{+} \mathrm{Foxp} 3^{-}$and $\mathrm{CD} 4^{+} \mathrm{CD} 25^{+} \mathrm{CD} 103^{+}$cells in the periphery of four strains of mice. Cells from lymph nodes (LN) and spleen of 9-week-old female C57BL/6 (B6), BALB/c, SJL and (NZBxNZW)F1 (BWF1) mice were labeled with anti-CD4, anti-CD25, anti-Foxp3, antiCD103 and anti-Ki67 antibodies and analyzed by FACS ${ }^{\oplus}$. (A) Labeled $C D 4^{+}$Foxp $3^{+}$cells were gated and analyzed for the percentages of cells expressing Ki67 in LN and spleen. (B) Labeled $\mathrm{CD}^{+}{ }^{+}$Foxp $3^{-}$cells were gated and analyzed for the percentages of cells expressing $\mathrm{Ki} 67$ in $\mathrm{LN}$ and spleen. (C) Labeled $\mathrm{CD} 4{ }^{+} \mathrm{CD} 25^{+} \mathrm{CD} 103^{+}$cells were gated and analyzed for the percentages of cells expressing Ki67 in LN and spleen. (D) Proliferation ratios were calculated by dividing the percentage of proliferating $\left(\mathrm{Ki} 67^{+}\right) \mathrm{CD} 4^{+} \mathrm{Foxp} 3^{+}$ cells by the percentage of proliferating $\mathrm{CD}^{+}{ }^{+}$Foxp $3^{-}$cells from $\mathrm{LN}$ and spleen $(\mathrm{n}=15)$. (A, B, C) A representative experiment of $\mathbf{3}$ performed is shown. Each symbol represents an individual animal. Statistical differences were analyzed using a student's $t$ test or ANOVA and the Tukey-Kramer multiple comparisons test. ${ }^{*} \mathrm{p}<0.05,{ }^{* *} \mathrm{p}<0.005$, and $* * * \mathrm{p}<0.0005$ 
A

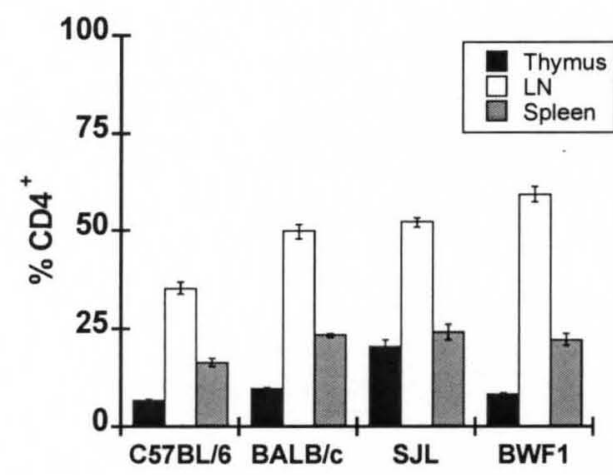

C

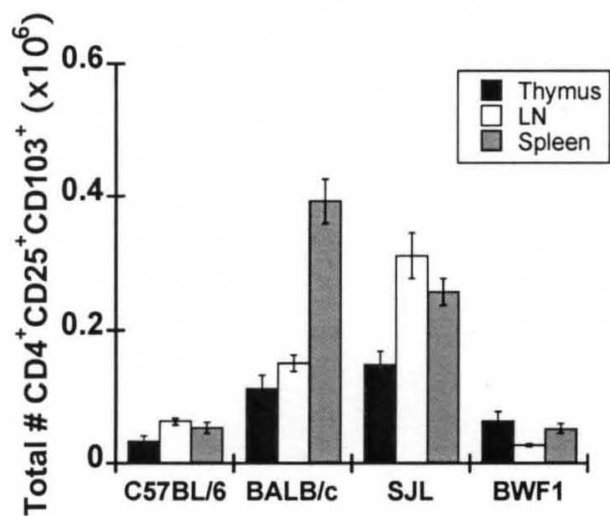

B

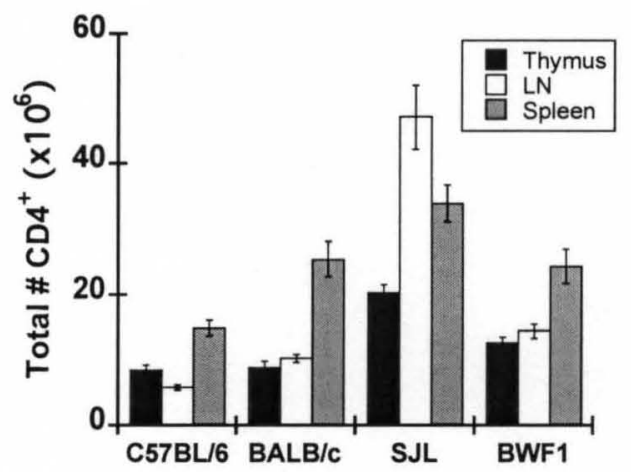

D

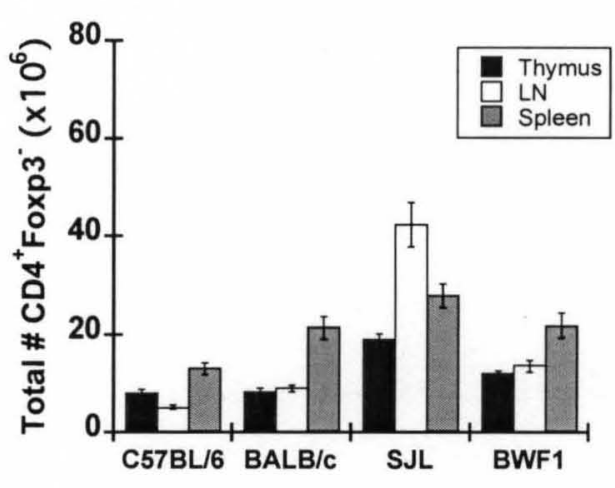

Figure 6. Percentages and numbers of $\mathrm{CD} 4^{+}$cells and numbers of $\mathrm{CD} 4^{+} \mathrm{CD} 25^{+} \mathrm{CD} 103^{+}$ cells. Cells from thymus, lymph nodes (LN) and spleen of 9-week-old female C57BL/6 (B6), BALB/c, SJL and (NZBxNZW)F1 (BWF1) mice were labeled with anti-CD4, antiCD25, anti-CD103 and anti-Foxp3 antibodies and analyzed by FACS ${ }^{\oplus}$. (A) Percentages and (B) numbers of $\mathrm{CD} 4$ single positive cells were determined. (C) Labeled $\mathrm{CD} 4^{+} \mathrm{CD} 25^{+}$ cells ( $\mathrm{CD} 4^{+} \mathrm{CD}^{+} \mathrm{CD} 25^{+}$cells in the thymus) were gated and numbers of cells expressing CD103 were determined. (D) $\mathrm{CD}^{+}{ }^{+} \mathrm{Foxp} 3^{-}$cells $\left(\mathrm{CD} 4^{+} \mathrm{CD} 8^{+} \mathrm{Foxp} 3^{-}\right.$cells in the thymus) were gated and numbers of cells were determined. 

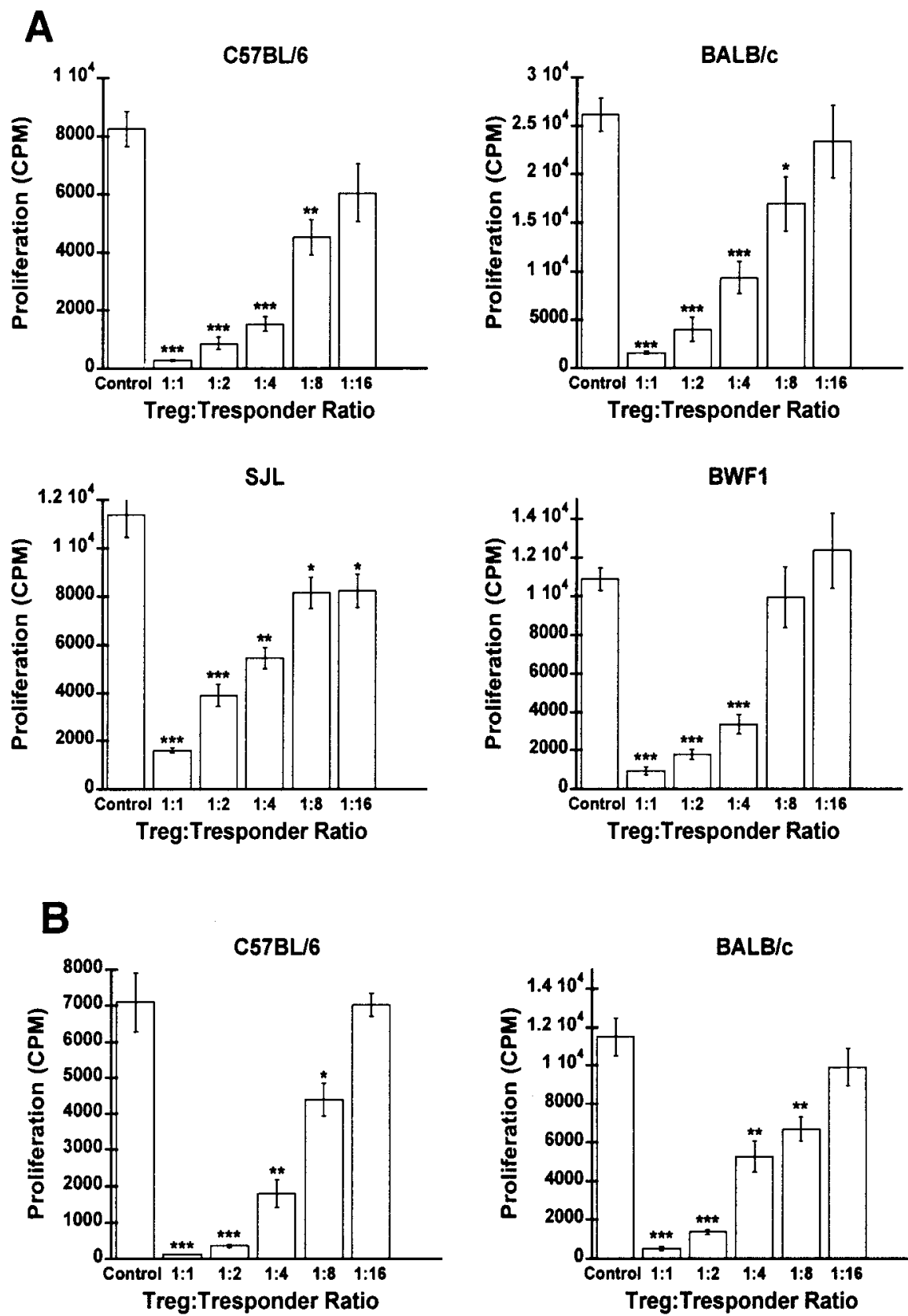

BALB/C
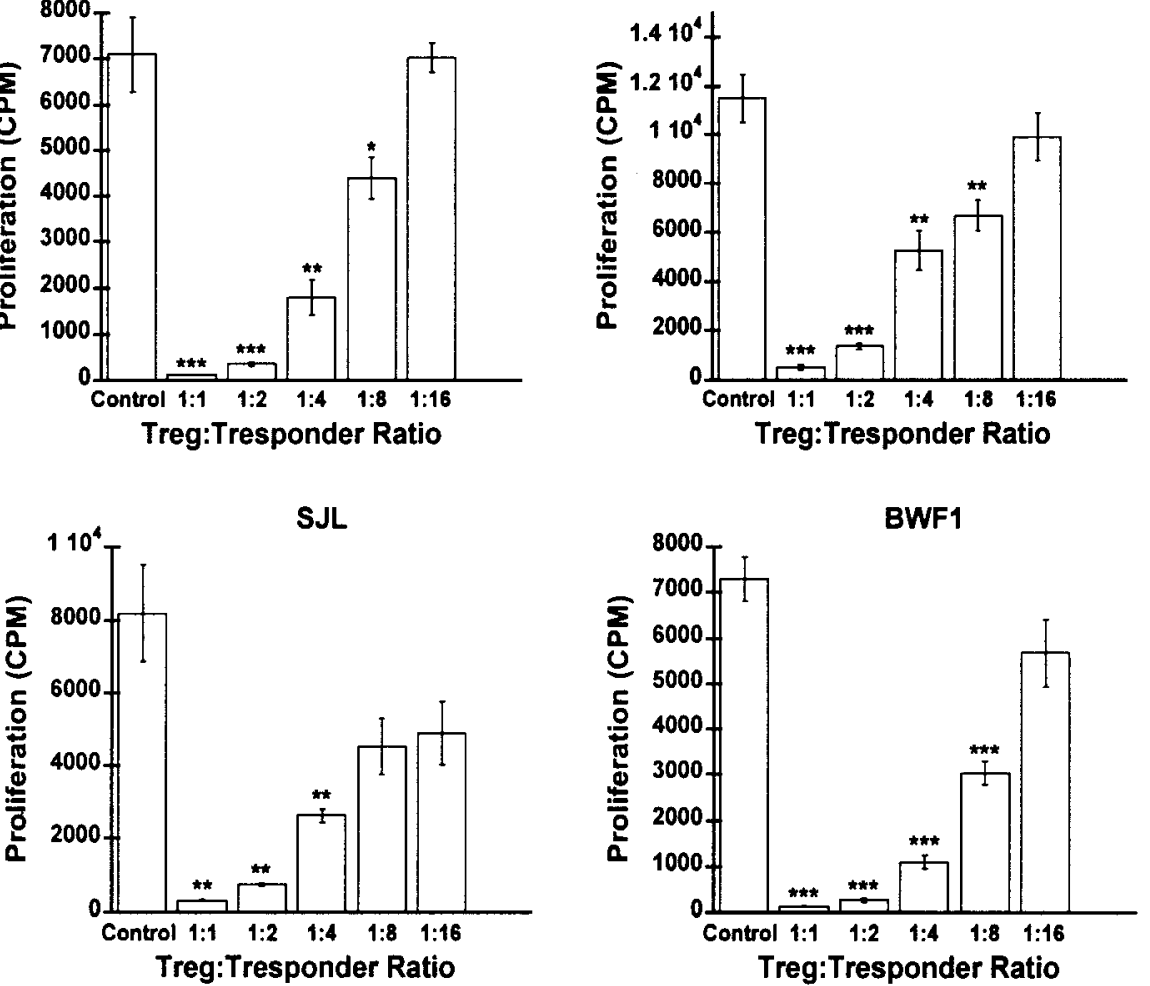

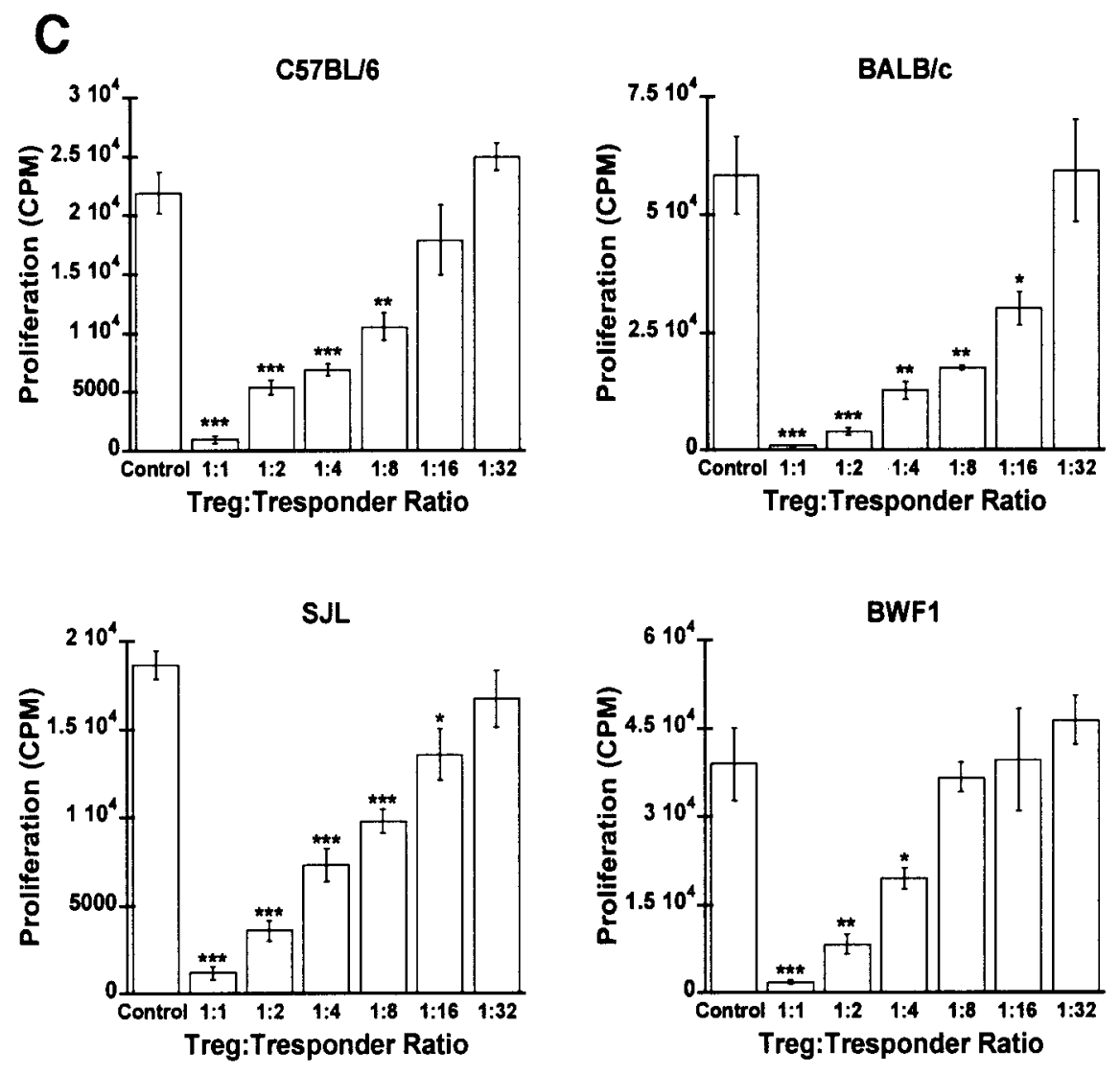

Figure 7. In vitro analysis of suppression by $\mathrm{CD} 4^{+} \mathrm{CD} 25^{+}$and $\mathrm{CD} 4^{+} \mathrm{CD} 25^{+} \mathrm{CD} 103^{+}$cells from four strains of mice. $\mathrm{CD}^{+} \mathrm{CD} 25^{+}(\mathrm{A}, \mathrm{B})$ or $\mathrm{CD} 4^{+} \mathrm{CD} 25^{+} \mathrm{CD} 103^{+}(\mathrm{C})$ cells were purified from 9-week-old female C57BL/6, BALB/c, SJL, and BWF1 mice and varying numbers co-cultured with a constant number of $(\mathrm{A}, \mathrm{C})$ autologous or $(\mathrm{B}) \mathrm{C} 57 \mathrm{BL} / 6$ $\mathrm{CD}^{+} \mathrm{CD} 25^{-}$responder cells and either $(\mathrm{A}, \mathrm{C})$ autologous or $(\mathrm{B}) \mathrm{C} 57 \mathrm{BL} / 6$ irradiated spleen cells and soluble anti-CD3 antibody. A representative experiment from among (A) 4-5 separate experiments or (B, C) 2-4 separate experiments is shown. Data are shown as mean counts per minute $(\mathrm{CPM}) \pm \mathrm{SEM}$ and statistical differences were analyzed using a student's $t$ test or ANOVA and the Tukey-Kramer multiple comparisons test. ${ }^{*} \mathrm{p}<0.05,{ }^{* *} \mathrm{p}<0.005,{ }^{* * *} \mathrm{p}<0.0005$ compared to control. 


\begin{tabular}{|c|c|c|c|c|}
\hline \multicolumn{6}{|c|}{ Table 1: Thymic Weights (mg) and Total Cell \#s $(\mathbf{x 1 0})^{\mathbf{6}}$} \\
\hline Strains & $\begin{array}{c}\text { Thymic Weights } \\
(\mathbf{m g}) \mathbf{n}=\mathbf{2 0}\end{array}$ & $\begin{array}{c}\text { Thymus Total } \\
\text { Cell \#s (x106) } \\
\mathbf{n = 1 6}\end{array}$ & $\begin{array}{c}\text { LN Total Cell \#s } \\
(\mathbf{x 1 0 6}) \mathbf{n = 1 6}\end{array}$ & $\begin{array}{c}\text { Spleen Total Cell } \\
\text { \#s }(\mathbf{x 1 0 6}) \mathbf{n}=\mathbf{1 6}\end{array}$ \\
\hline C57BL/6 & $46.2 \pm 2.3$ & $149.3 \pm 9.8$ & $17.6 \pm 1.0$ & $106.5 \pm 5.7$ \\
\hline BALB/c & $38.1 \pm 0.9$ & $109.0 \pm 6.2$ & $21.2 \pm 1.2$ & $124.1 \pm 5.4$ \\
\hline SJL & $52.2 \pm 2.4$ & $121.7 \pm 9.1$ & $106.8 \pm 10.3$ & $163.0 \pm 6.4$ \\
\hline BWF1 & $78.9 \pm 1.9$ & $176.3 \pm 10.6$ & $26.4 \pm 1.3$ & $118.5 \pm 6.9$ \\
\hline
\end{tabular}

Table 1. Thymic weights and cell numbers in thymus, lymph nodes and spleen in four strains of mice. Thymus, lymph nodes and spleen were collected from 9-week-old female C57BL/6, BALB/c, SJL and BWF1 mice and weights or cell numbers determined. 


\section{SPECIFIC AIM II}

\section{Decrease in regulatory $T$ cell percentages, but not function, may contribute to female susceptibility to autoimmune disease.}

Women are more susceptible to many autoimmune diseases than men (1). For example, women are nine times more likely to develop systemic lupus erythematosus (1). This increased susceptibility to disease can be seen in many mouse models of autoimmunity as well $(66,67,109,172,173)$. It has been shown that regulatory $\mathrm{T}$ cells are an important cell type in the control of autoimmune disease (123). Mice that lack functional Foxp3, and thus lack regulatory $\mathrm{T}$ cells, live only to 21 days of age and develop severe autoimmune disease (127). These mice can be rescued from disease by adoptive transfer of regulatory $\mathrm{T}$ cells (127). To determine how gender differences in regulatory $\mathrm{T}$ cells could contribute to autoimmune disease susceptibility, we investigated regulatory $\mathrm{T}$ cell function and percentages in females and males from four different strains of mice, two autoimmune-prone strains, the (NZBxNZW)F1 (BWF1) and SJL strains, and two less autoimmune-prone strains, the $\mathrm{C} 57 \mathrm{BL} / 6$ and $\mathrm{BALB} / \mathrm{c}$ strains. Female BWF1 mice develop lupus-like disease spontaneously whereas males only develop disease after castration. SJL mice are susceptible to multiple induced autoimmune diseases, while $\mathrm{C} 57 \mathrm{BL} / 6$ and $\mathrm{BALB} / \mathrm{c}$ mice are both relatively resistant to induced disease. 


\section{$\mathrm{CD}^{+} \mathrm{CD}^{+}{ }^{+}$regulatory cells from young female C57BL/6, BALB/c, SJL, and BWF1}

mice function similarly to strain-matched males in an in vitro suppression assay.

To compare inherent Treg function between females and males, we cultured varying numbers of bead-purified $\mathrm{CD} 4^{+} \mathrm{CD} 25^{+}$cells from 8-9-week-old female and male mice of each strain in a standard in vitro suppression assay, using syngeneic male $\mathrm{CD} 4^{+} \mathrm{CD} 25^{-} \mathrm{T}$ cells as responders, syngeneic male irradiated spleen cells as APC, and anti-CD3 antibody to stimulate. While in vitro suppression assays do not necessarily reflect exactly what is happening in vivo, they do allow for comparison of the suppressive function of regulatory $\mathrm{T}$ cells between groups in a controlled environment. We found no significant differences between female and male $\mathrm{CD} 4^{+} \mathrm{CD} 25^{+}$Treg suppressive function in vitro in any of the four strains studied (Figure 8). This result was surprising for BWF1 mice in particular, as females are more susceptible to disease in this strain. These data suggest that there is no inherent defect in female Treg suppressive function in the autoimmune-prone and less autoimmune-prone strains in this study, although this does not rule out the possibility that differences in female and male Treg function exist in vivo.

\section{Female lupus-prone BWF1 mice have significantly lower percentages of $\mathrm{CD4}^{+} \mathrm{Foxp}^{+}{ }^{+}$Tregs than BWF1 males.}

The $\mathrm{CD} 4^{+} \mathrm{CD} 25^{+}$regulatory $\mathrm{T}$ cells from female autoimmune-prone mice did not show decreased suppressive function in vitro compared to males (Figure 8). This led us to hypothesize that perhaps it was a decreased ratio or absolute number of Tregs in female mice and not a defect in their function that contributed to their disease susceptibility. Although there were no differences in the percentages of $\mathrm{CD} 4^{+} \mathrm{T}$ cells between female 
and male mice of any of the four strains studied in either LN or spleen (Table 2), female BWF1 mice did have significantly lower $\mathrm{CD}^{+}{ }^{+} \mathrm{Foxp}^{+}$cell percentages in the $\mathrm{LN}$, but not spleen, than males (Figure 9A). No consistent gender differences were seen in the percentages of $\mathrm{CD}^{+}{ }^{+} \mathrm{Foxp}^{+}$cells in either $\mathrm{LN}$ or spleen of $\mathrm{C} 57 \mathrm{BL} / 6, \mathrm{BALB} / \mathrm{c}$, or SJL mice, however $\mathrm{C} 57 \mathrm{BL} / 6$ females trended toward having lower percentages in experiments even when they were not actually significantly lower (Figure 9A, Table 3). Although the percentage of $\mathrm{CD} 4^{+} \mathrm{Foxp}^{+}$cells was significantly lower in the LN of female BWF1 mice, there were no differences between female and male mice in the total cell number of $\mathrm{CD}^{+} \mathrm{Foxp}^{+}$cells in $\mathrm{LN}$ or spleen (Figure 9B). Interestingly, in the $\mathrm{LN}$ of both SJL and BALB/c mice, females tended to have statistically higher total $\mathrm{CD}^{+}{ }^{+}$Foxp $3^{+}$cell numbers than males, although not always significant (Figure 9B, Table 4A). This increase in $\mathrm{CD}^{+}{ }^{+} \mathrm{Foxp} 3^{+}$cell numbers in $\mathrm{LN}$ of female SJL and BALB/c mice compared to male mice is no doubt due to the greater number of $\mathrm{CD}^{+}$cells found in $\mathrm{LN}$, in general, in female compared to male SJL mice (Table 5A). C57BL/6 mice showed no gender difference in $\mathrm{CD}^{+} \mathrm{Foxp}^{+}$total cell number (Figure 9B, Table 4). Similar to $\mathrm{CD} 4^{+}$Foxp $3^{+}$cell percentages, BWF1 females had significantly lower percentages of $\mathrm{CD}^{+} \mathrm{CD} 25^{+}$cells in $\mathrm{LN}$, but not spleen, while none of the other strains showed a gender difference in percentages of these cells (Figure 9C). There were no gender differences in per cell expression of Foxp 3 in $\mathrm{CD} 4{ }^{+} \mathrm{CD} 25^{+} \mathrm{T}$ cells in any of the four strains studied (Figure 9D, Table 6). Together, these data suggest that in BWF1 mice, in which females are more susceptible to disease, a lower Treg:effector cell ratio in female mice could contribute to increased disease susceptibility. 


\section{Female mice from all four strains have significantly lower percentages of the potent $\mathrm{CD4}^{+} \mathrm{CD25}^{+} \mathrm{CD} \mathrm{C3}^{+}$regulatory $\mathrm{T}$ cell subset.}

CD103 $\left(\alpha_{E} \beta_{7}\right)$ is an integrin expressed on the surface of a more potent subset of Tregs that are thought to represent a memory/effector population (207-209). $\mathrm{CD} 4^{+} \mathrm{CD} 25^{+} \mathrm{CD} 103^{+}$Tregs have been shown to be more potent suppressors than $\mathrm{CD}^{+} \mathrm{CD} 25^{+} \mathrm{CD} 103^{-}$Tregs both in vitro and in vivo in mouse models of autoimmune disease $(149,207,211)$. CD103 helps retain Tregs at sites of inflammation where they are thought to receive activation signals contributing to their memory/effector Treg phenotype (212). To evaluate $\mathrm{CD} 103^{+}$Treg function in vitro, we cultured varying numbers of sorted $\mathrm{CD} 4^{+} \mathrm{CD} 25^{+} \mathrm{CD} 103^{+}$cells from female and male mice of each strain in a standard in vitro suppression assay, using syngeneic male $\mathrm{CD} 4^{+} \mathrm{CD} 25^{-} \mathrm{T}$ cells as responders, syngeneic male irradiated spleen cells as APC, and stimulated by anti-CD3 antibody. Again, as with the $\mathrm{CD} 4^{+} \mathrm{CD} 25^{+}$Tregs, we found no significant differences between female and male $\mathrm{CD} 4^{+} \mathrm{CD} 25^{+} \mathrm{CD} 103^{+}$Treg suppressive function in vitro in any of the four strains studied (Figure 10D). Thus, an inherent defect in female Treg suppressive function is not responsible for increased female susceptibility to disease, although this does not rule out the possibility that differences in female and male Treg function exist in vivo.

Females of all four strains of mice studied, which included both autoimmuneprone and less autoimmune-prone strains of mice, had significantly lower percentages of $\mathrm{CD}^{+} \mathrm{CD} 25^{+} \mathrm{CD} 103^{+}$cells in their LN compared to their male counterparts (Figure 10A). Interestingly, only lupus-prone female BWF1 mice had significantly lower percentages of $\mathrm{CD} 4^{+} \mathrm{CD} 25^{+} \mathrm{CD} 103^{+}$cells in spleens than male BWF1 mice (Figure 10A). Females from 
both C57BL/6 and BWF1 mouse strains had significantly lower total $\mathrm{CD}^{+} \mathrm{CD} 25^{+} \mathrm{CD} 103^{+}$cell numbers than strain-matched males in $\mathrm{LN}$, but not spleen (Table 7). Interestingly, not only did females of each strain have lower percentages of $\mathrm{CD}^{+} \mathrm{CD} 25^{+} \mathrm{CD} 103^{+}$cells in $\mathrm{LN}$ compared to males, but female BWF1 and C57BL/6 mice also expressed lower levels of CD103 than males in LN (Figure 10B, 10C, Table 8). These data together suggest that, particularly in the LN, gender may strongly influence $\mathrm{CD} 4^{+} \mathrm{CD} 25^{+} \mathrm{CD} 103^{+}$Treg populations. Gender differences, presumably hormonal differences, appear to impact this $\mathrm{CD} 103^{+}$Treg population more than the $\mathrm{CD} 4^{+} \mathrm{Foxp} 3^{+}$ Tregs in general.

\section{Thymic production of $\mathrm{CD}^{+} \mathrm{Foxp}^{+}$or $\mathrm{CD4}^{+} \mathrm{CD25}^{+} \mathrm{CD} 103^{+}$Tregs does not play a role in the lower percentages of these cells in the periphery.}

To determine whether a defect in thymic $\mathrm{CD} 4^{+} \mathrm{Foxp} 3^{+}$and/or $\mathrm{CD} 4^{+} \mathrm{CD} 25^{+} \mathrm{CD} 103^{+}$cell production was the cause of decreased Treg percentages in the periphery in females, we examined Treg populations in the thymus. We found no differences between female and male thymic percentages of $\mathrm{CD}^{+}{ }^{+} \mathrm{Foxp} 3^{+}$cells in the thymus of any of the four strains studied (Figure 11A, Table 3C). Interestingly, we found that both $\mathrm{BALB} / \mathrm{c}$ and SJL mice had higher total $\mathrm{CD} 4^{+} \mathrm{Foxp} 3^{+}$cell numbers in females than males, and while not always significant, both C57BL/6 and BWF1 females tended to have higher total $\mathrm{CD} 4^{+} \mathrm{Foxp}^{+}$cell numbers as well (Figure 9B, Table 4C). Although females had higher thymic total cell numbers in all four strains, only female SJL and female BWF1 mice had higher thymic weights than strain-matched males (Table 9A). 
There were no differences in percentages of thymic $\mathrm{CD} 4^{+} \mathrm{CD} 25^{+} \mathrm{CD} 103^{+}$cells between females and males in any of the four strains studied (Figure 11B). It is unclear whether the $\mathrm{CD} 4^{+} \mathrm{CD} 25^{+} \mathrm{CD} 103^{+}$cells found in the thymus develop there or have simply re-entered from the periphery, so we cannot completely rule out gender differences in thymic production (259). However, these data together suggest that it is unlikely that a defect in thymic production of Tregs is responsible for the decreased percentages of $\mathrm{CD}^{+}{ }^{+}$Foxp $3^{+}$cells seen in BWF1 females and the decreased percentages of $\mathrm{CD} 4^{+} \mathrm{CD} 25^{+} \mathrm{CD} 103^{+}$cells found in females of all four strains in the periphery.

\section{Differences in non-Treg proliferation in vivo may account for decreased} $\mathrm{CD4}^{+} \mathrm{Foxp}^{+}$peripheral percentages in female BWF1 mice, but proliferation does not appear to play a role in decreased female $\mathrm{CD4}^{+} \mathrm{CD}^{+} 5^{+} \mathrm{CD}_{103}{ }^{+}$peripheral percentages.

$\mathrm{T}$ cells cycle in the periphery, and it is, in part, through this mechanism that peripheral $\mathrm{T}$ cell populations, including Tregs, are maintained (257). A higher proliferation rate of male $\mathrm{CD} 4^{+} \mathrm{Foxp} 3^{+}$and $\mathrm{CD} 4^{+} \mathrm{CD} 25^{+} \mathrm{CD} 103^{+}$cells in vivo compared to females could account for lower peripheral Treg percentages in females. Alternatively, if the $\mathrm{CD}^{+}{ }^{+}$Foxp $3^{-}$(non-Treg) proliferation rate is higher in females than males, this could also account for decreased percentages of Tregs in the periphery of females. To detect proliferating cells, we used the Ki67 marker, which identifies cells in active cell cycle. It was only the BALB/c strain that exhibited differences in percentages of proliferating $\mathrm{CD}^{+}{ }^{+}$oxp $3^{+}$cells in either the $\mathrm{LN}$ or spleen (Figure 12A). However, the BALB/c strain does not have a gender difference in $\mathrm{CD} 4^{+} \mathrm{Foxp} 3^{+}$percentages in the periphery, so the 
significance of the differences in the proliferation rate is unclear. Interestingly, in the LN, female BWF1 mice had a higher percentage of proliferating $\mathrm{CD}^{+}{ }^{+} \mathrm{Foxp} 3^{-}$cells (non-Treg) than males, which, as discussed above, may contribute to the decreased ratio of $\mathrm{CD}^{+}{ }^{+}$oxp $3^{+}: \mathrm{CD}^{+}{ }^{+}$oxp $^{-}$cells found in the periphery in these mice (Figure 12B). None of the other three strains of mice showed gender differences in $\mathrm{CD}^{+}{ }^{+} \mathrm{Foxp} 3^{-}$proliferation in the LN (Figure 12B). SJL mice were the only strain with gender differences in the percentages of proliferating $\mathrm{CD}^{+} \mathrm{Foxp} 3^{-}$cells in the spleen, with more proliferating $\mathrm{CD} 4^{+}$Foxp $3^{-}$cells in females than males (Figure 12B). However, there were no gender differences in the percentage of $\mathrm{CD}^{+} \mathrm{Foxp}^{+}$cells in the periphery (either LN or spleen) of SJL mice. Interestingly, there were no gender differences in the percentages of proliferating $\mathrm{CD}^{+} \mathrm{CD} 25^{+} \mathrm{CD} 103^{+}$cells in any of the four strains studied in the $\mathrm{LN}$ or spleen (Figure 12C). This indicates that differences in proliferation of these cells in vivo do not account for gender differences in peripheral percentages of $\mathrm{CD} 4^{+} \mathrm{CD} 25^{+} \mathrm{CD} 103^{+}$ cells.

BWF1 mice were the only strain of the four studied where females had decreased percentages of $\mathrm{CD}^{+}{ }^{+} \mathrm{Foxp} 3^{+}$cells in the $\mathrm{LN}$ when compared to age- and strain-matched males (Figure 9A). Interestingly, BWF1 mice were also the only strain in which the ratio of proliferating Foxp $3^{+}$:Foxp $3^{-}$cells was significantly lower than the proliferation ratio in BWF1 males (Figure 12D). These data together suggest that increased proliferation of $\mathrm{CD} 4^{+}$Foxp $3^{-}$non-Tregs, which decreases the Foxp $3^{+}$:Foxp $3^{-}$proliferation ratio, in female BWF1 mice compared to males may contribute to the decreased $\mathrm{CD} 4^{+} \mathrm{Foxp} 3^{+}$ percentages seen in the LN. Furthermore, although one of the characteristics of $\mathrm{CD} 4^{+} \mathrm{CD} 25^{+} \mathrm{CD} 103^{+}$cells is that they proliferate at a much greater rate than 
$\mathrm{CD}^{+} \mathrm{CD} 25^{+} \mathrm{CD} 103^{-}$cells, the lower percentages of these cells in the periphery of females was not due to a lower proliferation rate among these cells.

\section{Summary}

In this study, we have found that regulatory:effector $\mathrm{T}$ cell ratio and not inherent suppressive function of Tregs, are reduced in the periphery of autoimmune-prone mice. The potent $\mathrm{CD} 4^{+} \mathrm{CD} 25^{+} \mathrm{CD} 103^{+}$regulatory $\mathrm{T}$ cell subset may be most sensitive to hormonal influence, as these cells are found at lower percentages in the periphery of female mice of all four strains studied in comparison to strain-matched males. Neither a defect in thymic production or differences in homeostatic proliferation could account for the differences in peripheral percentages seen between females and males. Other mechanisms will need to be explored to explain the lower $\mathrm{CD} 4^{+} \mathrm{CD} 25^{+} \mathrm{CD} 103^{+}$Treg percentages seen in female mice and will be discussed further in the general discussion. 
C57BL/6

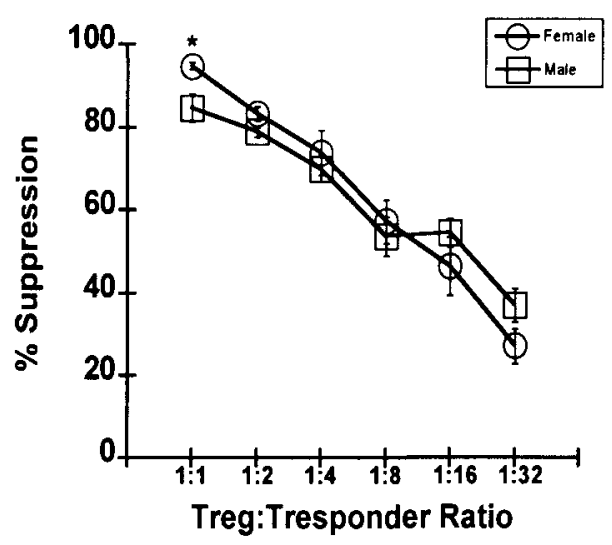

SJL

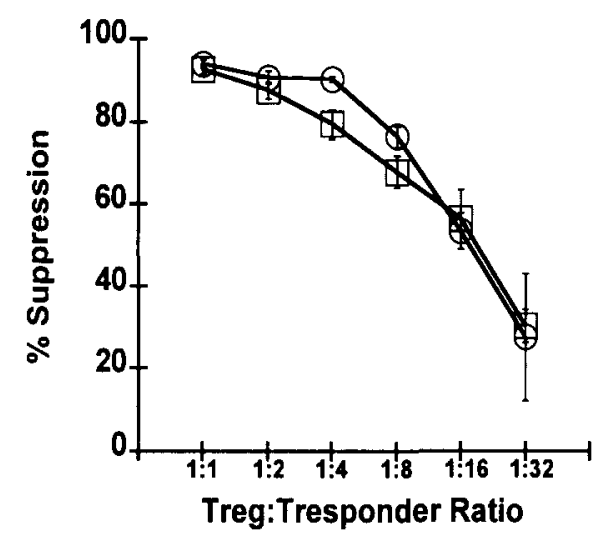

BALB/C

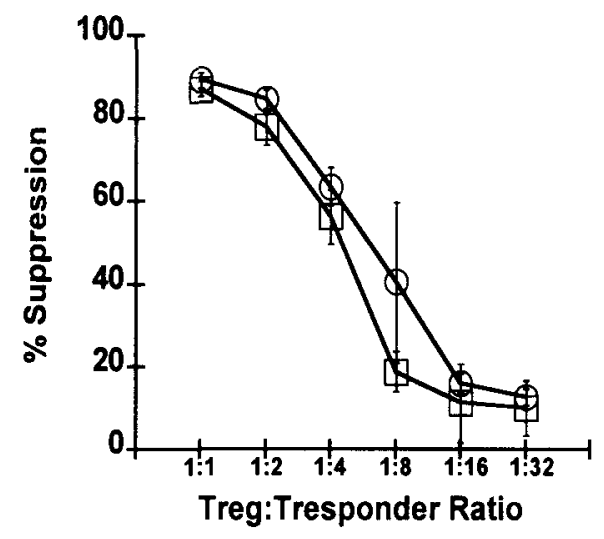

BWF1

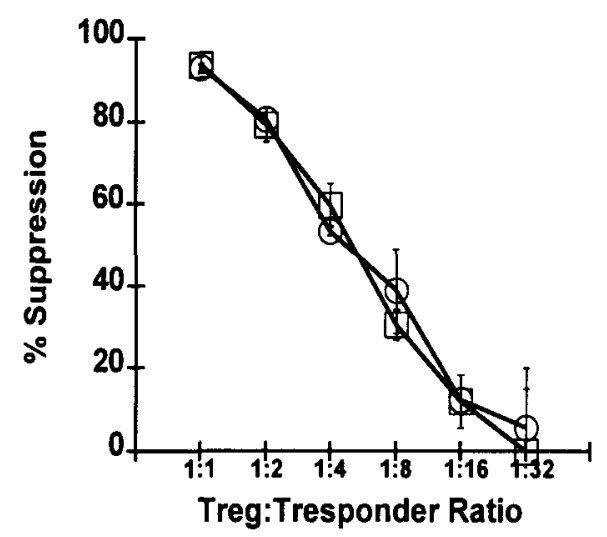

Figure 8. Regulatory function of female vs. male $\mathrm{CD} 4^{+} \mathrm{CD} 25^{+}$cells from four strains of mice. $\mathrm{CD}^{+} \mathrm{CD} 25^{+}$cells were purified from 8-9-week-old female and male $\mathrm{C} 57 \mathrm{BL} / 6$, $\mathrm{BALB} / \mathrm{c}, \mathrm{SJL}$, and BWF1 mice and varying numbers co-cultured with a constant number of syngeneic male $\mathrm{CD} 4^{+} \mathrm{CD} 25^{-}$responder cells and male APC and soluble anti-CD3 antibody. \% suppression of positive control (responder cells alone) was calculated and the mean \pm SEM presented. Statistical differences were analyzed using a student's $t$ test or ANOVA and the Tukey-Kramer multiple comparisons test. ${ }^{*} \mathrm{p}<0.05,{ }^{* *} \mathrm{p}<0.005$, and $* * * \mathrm{p}<0.0005$. 
A

LN

Spleen
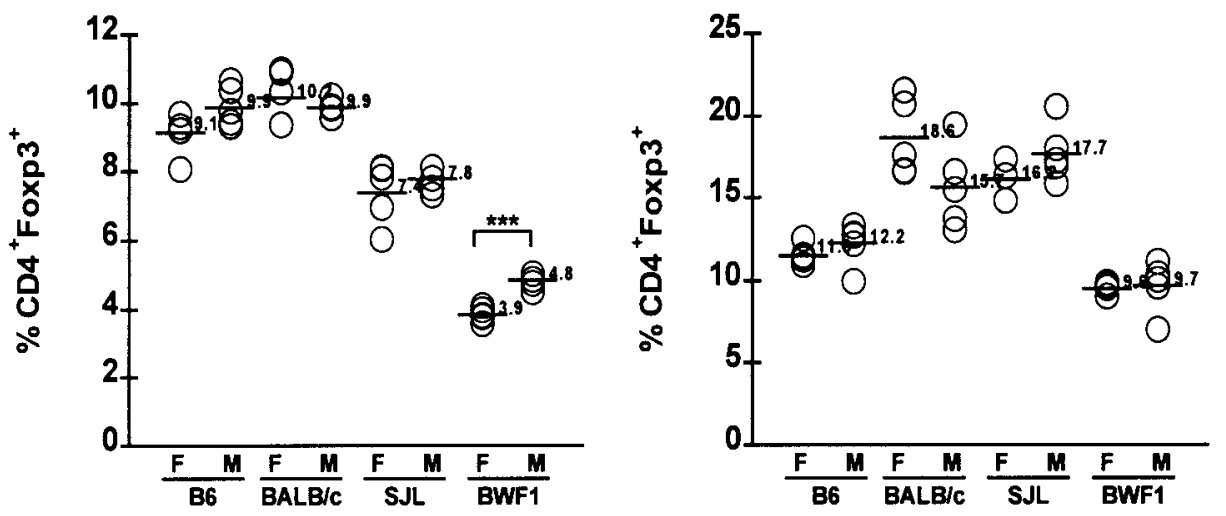

B
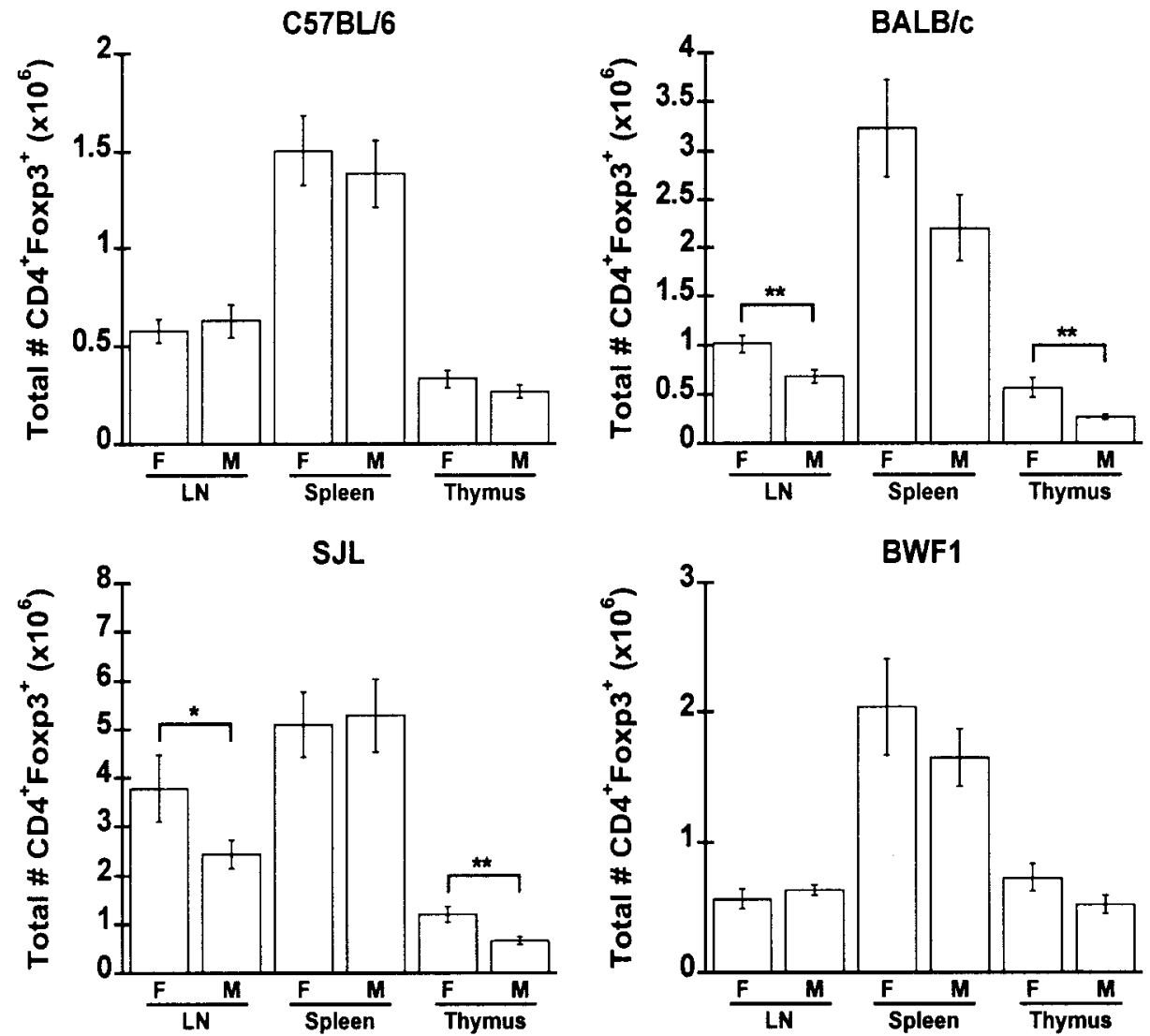
C

LN

Spleen
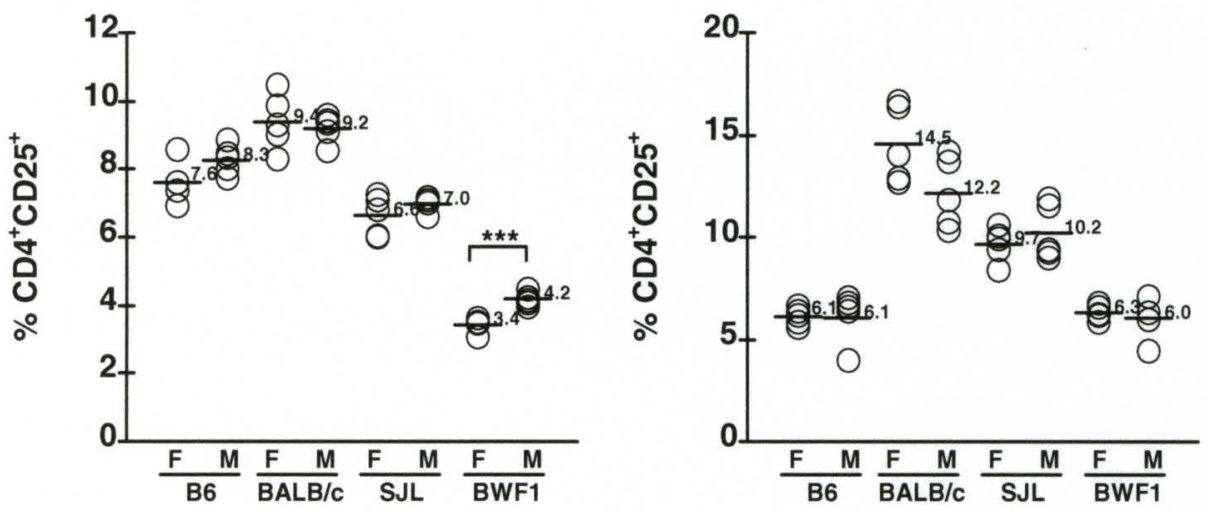

D

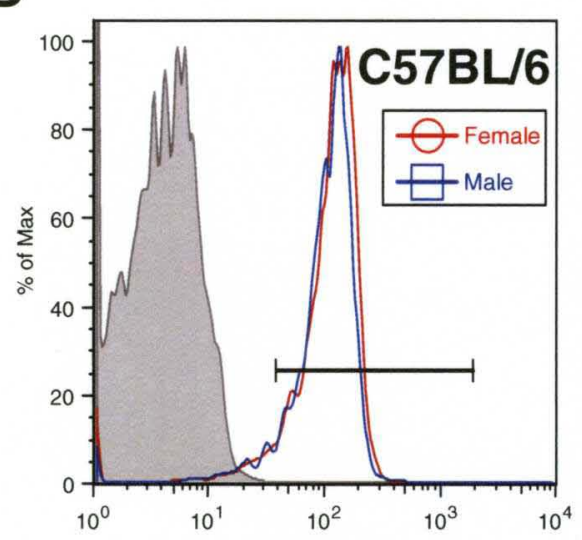

Foxp3
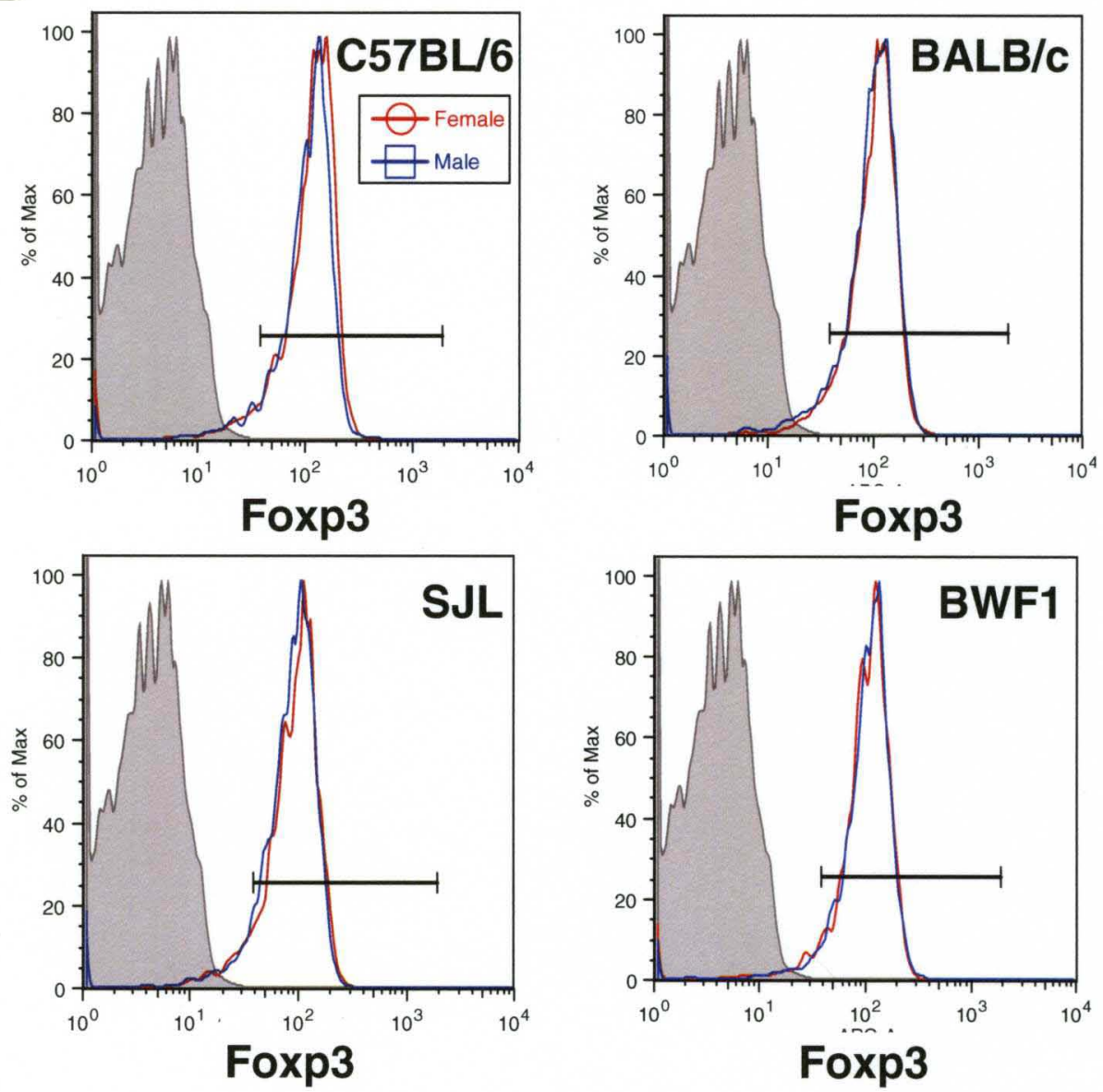

Foxp3

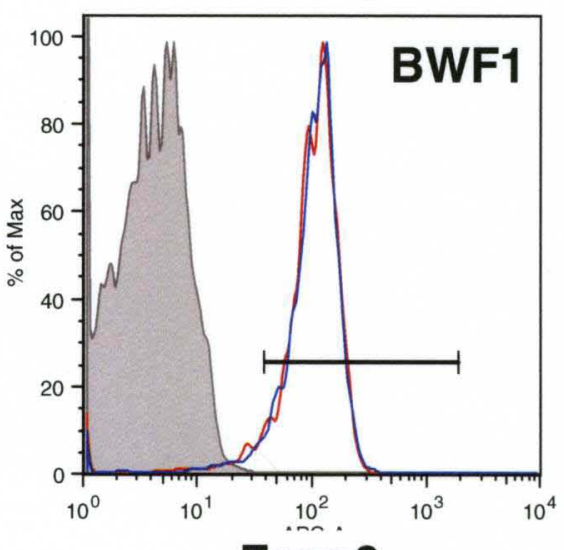

Foxp3 
Figure 9. Percentages and numbers of $\mathrm{CD} 4^{+} \mathrm{Foxp} 3^{+}$cells in four strains of mice. Cells from lymph nodes (LN) and spleen of 8-9-week-old female and male C57BL/6 (B6), $\mathrm{BALB} / \mathrm{c}, \mathrm{SJL}$ and (NZBxNZW)F1 (BWF1) mice were labeled with anti-CD4, anti-CD25, and anti-Foxp3 antibodies and analyzed by FACS ${ }^{\circledast}$. (A) Labeled $\mathrm{CD} 4^{+}$cells were gated and analyzed for the percentages of cells expressing Foxp3 in LN and spleen. (B) The total numbers of $\mathrm{CD} 4^{+} \mathrm{Foxp} 3^{+}$cells in lymph nodes, spleen, and thymus are shown. (C) Labeled $\mathrm{CD}^{+}$cells were gated and analyzed for the percentages of cells expressing CD25 in LN and spleen. (D) A sample histogram showing Foxp3 expression on $\mathrm{CD} 4{ }^{+} \mathrm{CD} 25^{+}$cells in $\mathrm{LN}$ is shown. (A, C) A representative experiment of $4-9$ performed is shown. Each symbol represents an individual animal. Statistical differences were analyzed using a student's t test or ANOVA and the Tukey-Kramer multiple comparisons test. ${ }^{*} \mathrm{p}<0.05,{ }^{* *} \mathrm{p}<0.005$, and ${ }^{* * *} \mathrm{p}<0.0005$. 
A

LN

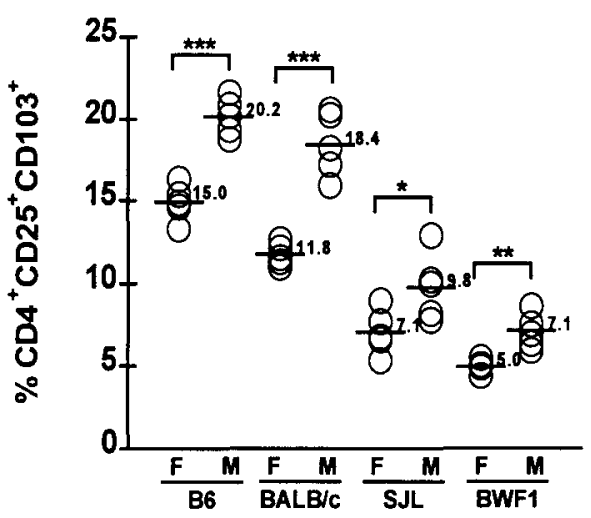

B

LN

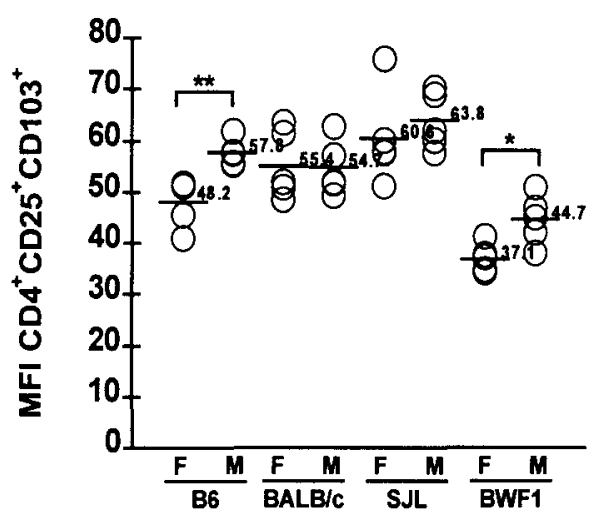

\section{Spleen}

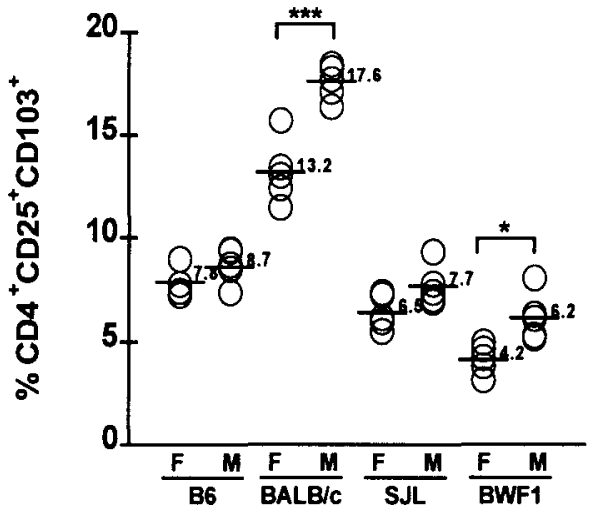

Spleen

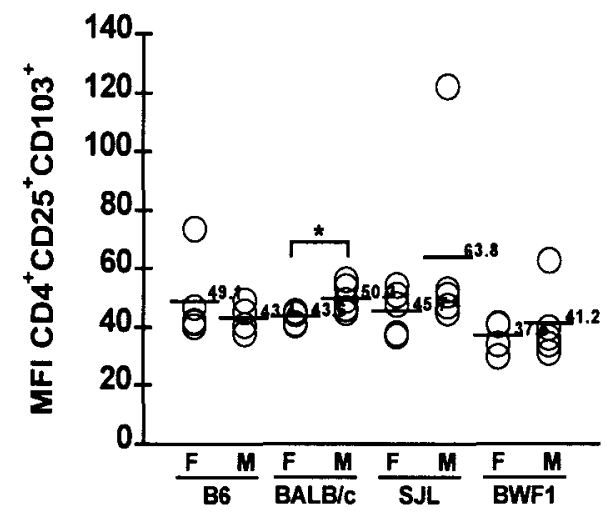



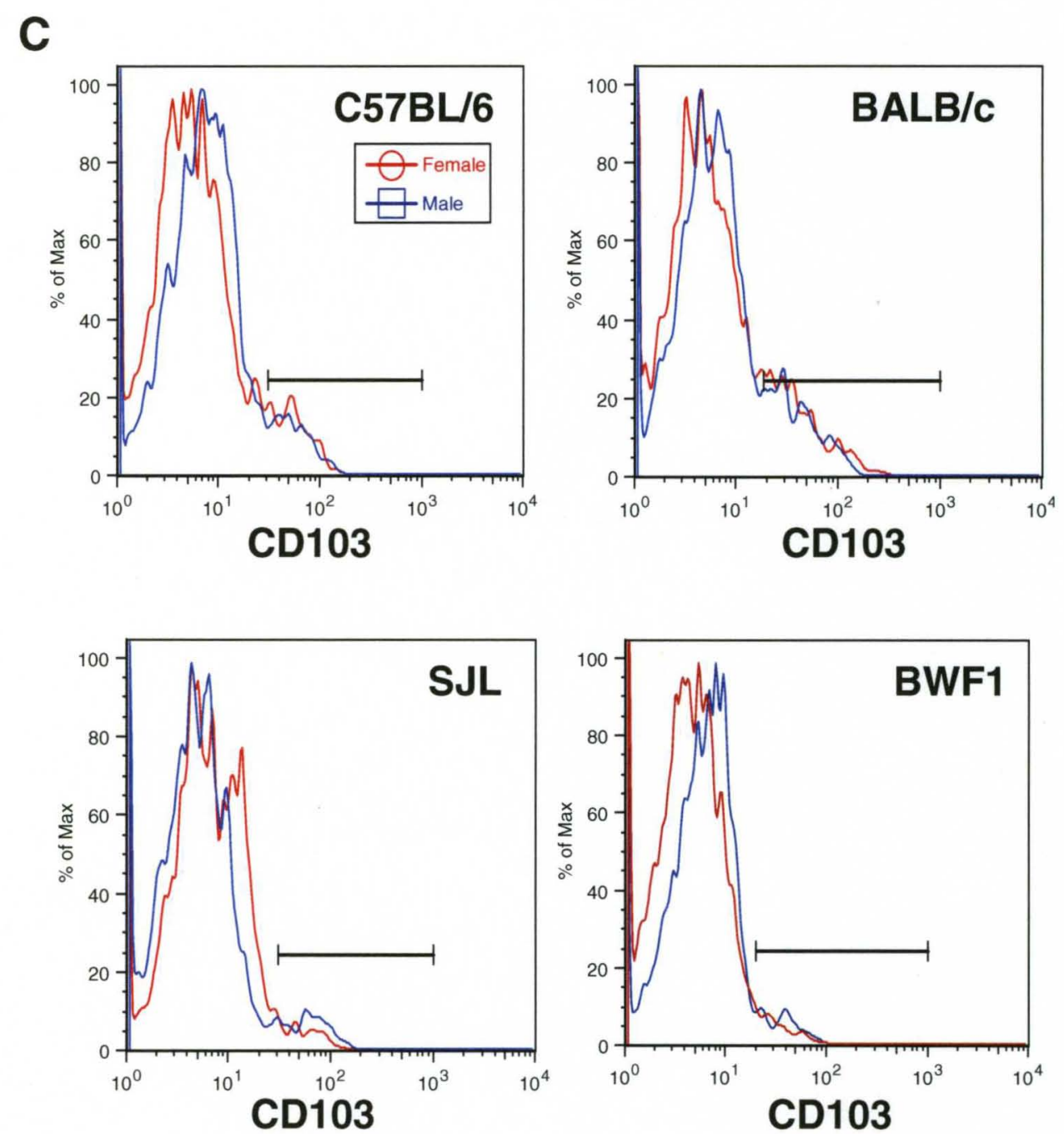

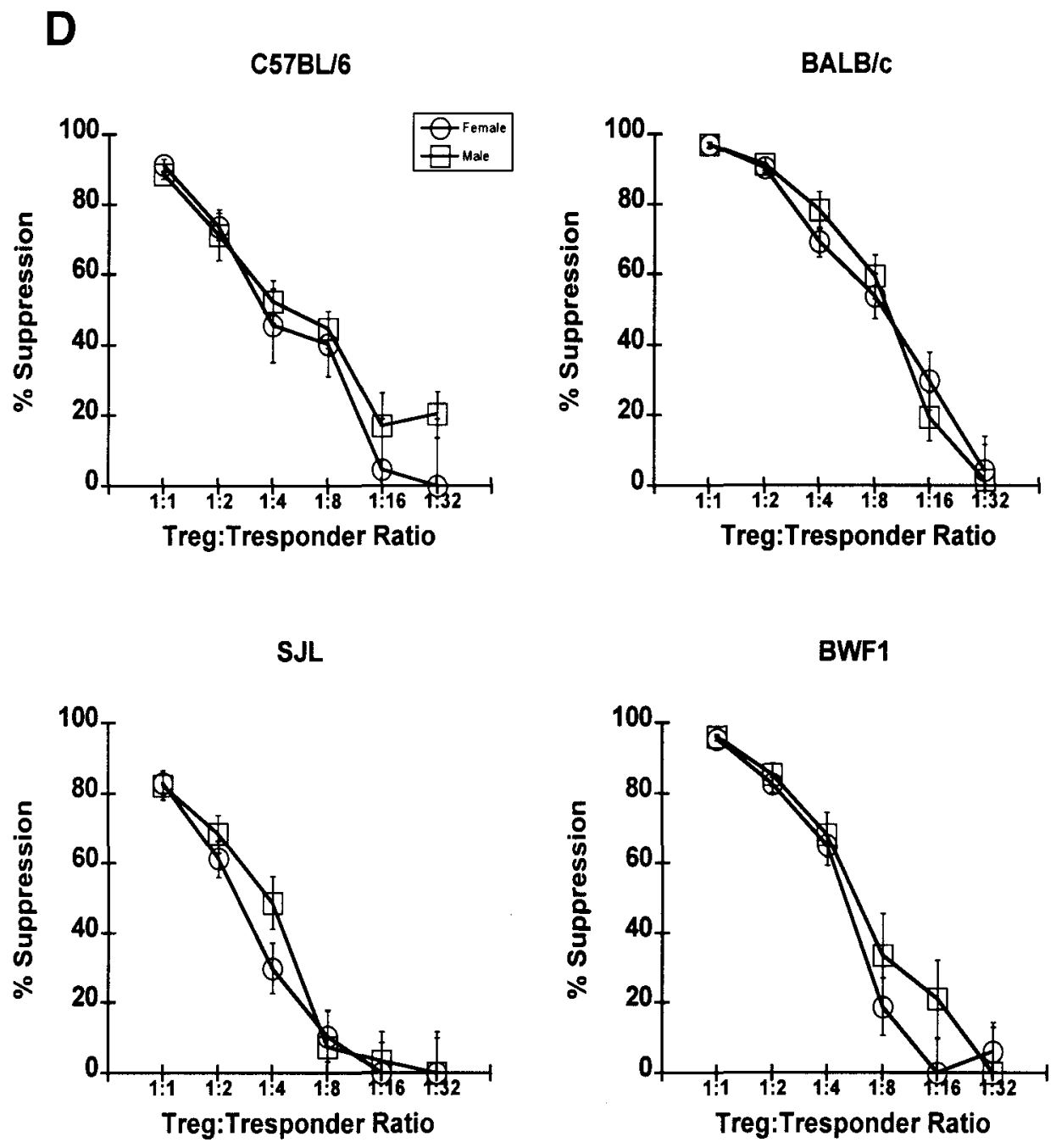

Figure 10. Percentages and suppressive function in vitro of $\mathrm{CD}^{+} \mathrm{CD} 25^{+} \mathrm{CD} 103^{+}$cells in four strains of mice. Cells from lymph nodes (LN) and spleen of 8-9-week-old female and male C57BL/6 (B6), BALB/c, SJL and (NZBxNZW)F1 (BWF1) mice were labeled with anti-CD4, anti-CD25, and anti-CD103 antibodies and analyzed by FACS ${ }^{\circledR}$. (A) Labeled $\mathrm{CD} 4{ }^{+} \mathrm{CD} 25^{+}$cells were gated and analyzed for the percentages of cells expressing CD103 in LN and spleen. (B) Labeled $\mathrm{CD} 4^{+} \mathrm{CD} 25^{+}$cells were gated and analyzed for the per cell expression of CD103 in LN and spleen. (C) A sample histogram 
showing $\mathrm{CD} 103$ expression on $\mathrm{CD} 4^{+} \mathrm{CD} 25^{+}$cells in $\mathrm{LN}$ is shown. (D) $\mathrm{CD}^{+} \mathrm{CD} 25^{+} \mathrm{CD} 103^{+}$cells were purified from female and male $\mathrm{C} 57 \mathrm{BL} / 6, \mathrm{BALB} / \mathrm{c}, \mathrm{SJL}$, and BWF1 mice and varying numbers co-cultured with a constant number of syngeneic male $\mathrm{CD} 4^{+} \mathrm{CD} 25$ responder cells and $\mathrm{APC}$ and soluble anti-CD3 antibody. \% suppression of positive control (responder cells alone) was calculated and the mean \pm SEM presented. (A,B) A representative experiment of 4-9 performed is shown. Each symbol represents an individual animal. Statistical differences were analyzed using a student's $t$ test or ANOVA and the Tukey-Kramer multiple comparisons test. ${ }^{*} \mathrm{p}<0.05$, ${ }^{* *} \mathrm{p}<0.005$, and $* * * \mathrm{p}<0.0005$. 
A

Thymus

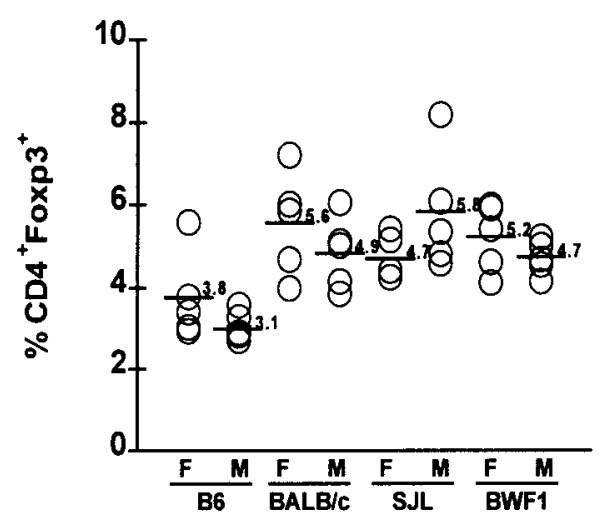

B

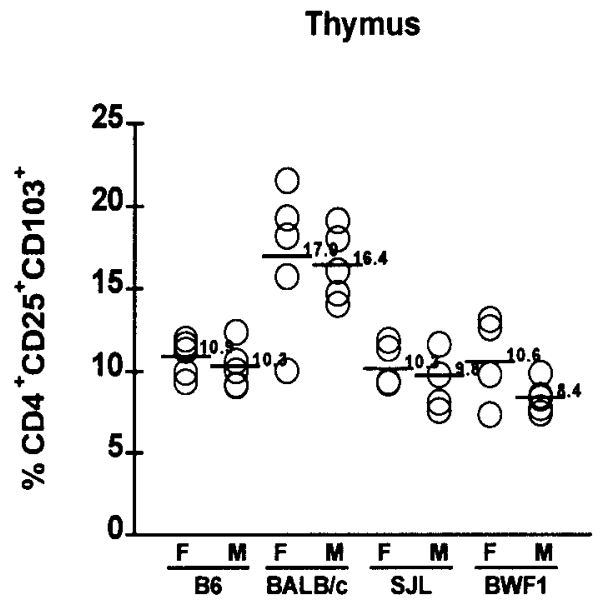

Figure 11. Percentages of $\mathrm{CD}^{+} \mathrm{Foxp}^{+}$and $\mathrm{CD} 4^{+} \mathrm{CD} 25^{+} \mathrm{CD} 103^{+}$cells in thymus in four strains of mice. Cells from lymph nodes ( $\mathrm{LN})$ and spleen of 8-9-week-old female and male C57BL/6 (B6), BALB/c, SJL and (NZBxNZW)F1 (BWF1) mice were labeled with anti-CD4, anti-CD25, anti-CD103, and anti-Foxp3 antibodies and analyzed by FACS ${ }^{\oplus}$. Labeled cells were gated and analyzed for (A) percentages of $\mathrm{CD} 4^{+}$cells expressing Foxp3 and (B) percentages of $\mathrm{CD} 4^{+} \mathrm{CD} 25^{+}$cells expressing $\mathrm{CD} 103$. A representative experiment of 4 performed is shown. Each symbol represents an individual animal. Statistical differences were analyzed using a student's $t$ test or ANOVA and the TukeyKramer multiple comparisons test. ${ }^{*} \mathrm{p}<0.05,^{* *} \mathrm{p}<0.005$, and ${ }^{* * *} \mathrm{p}<0.0005$. 
A
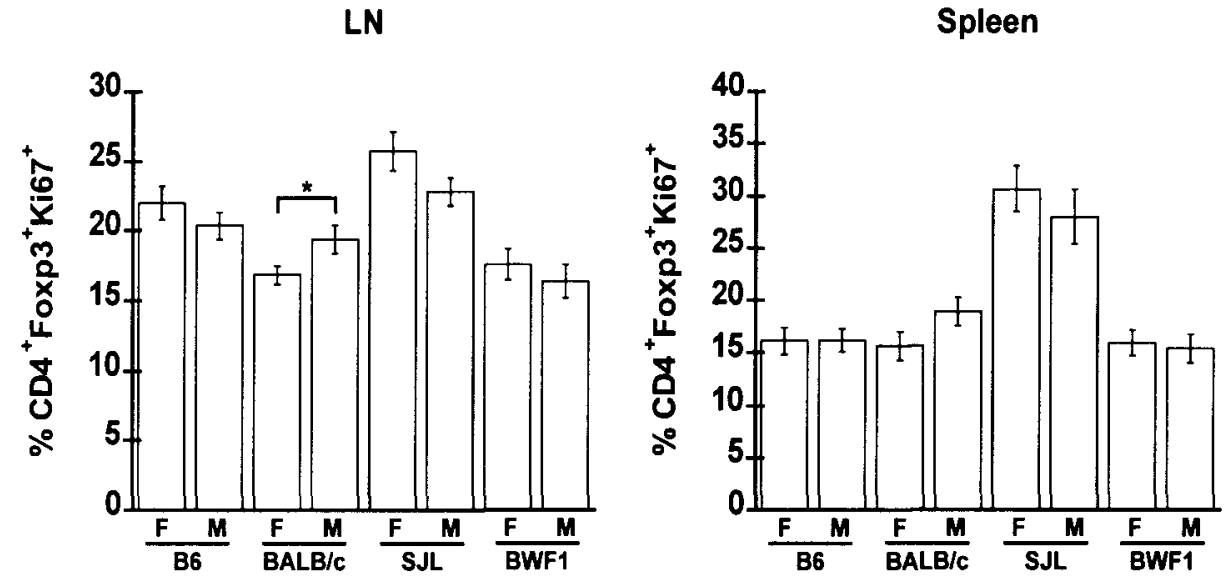

B
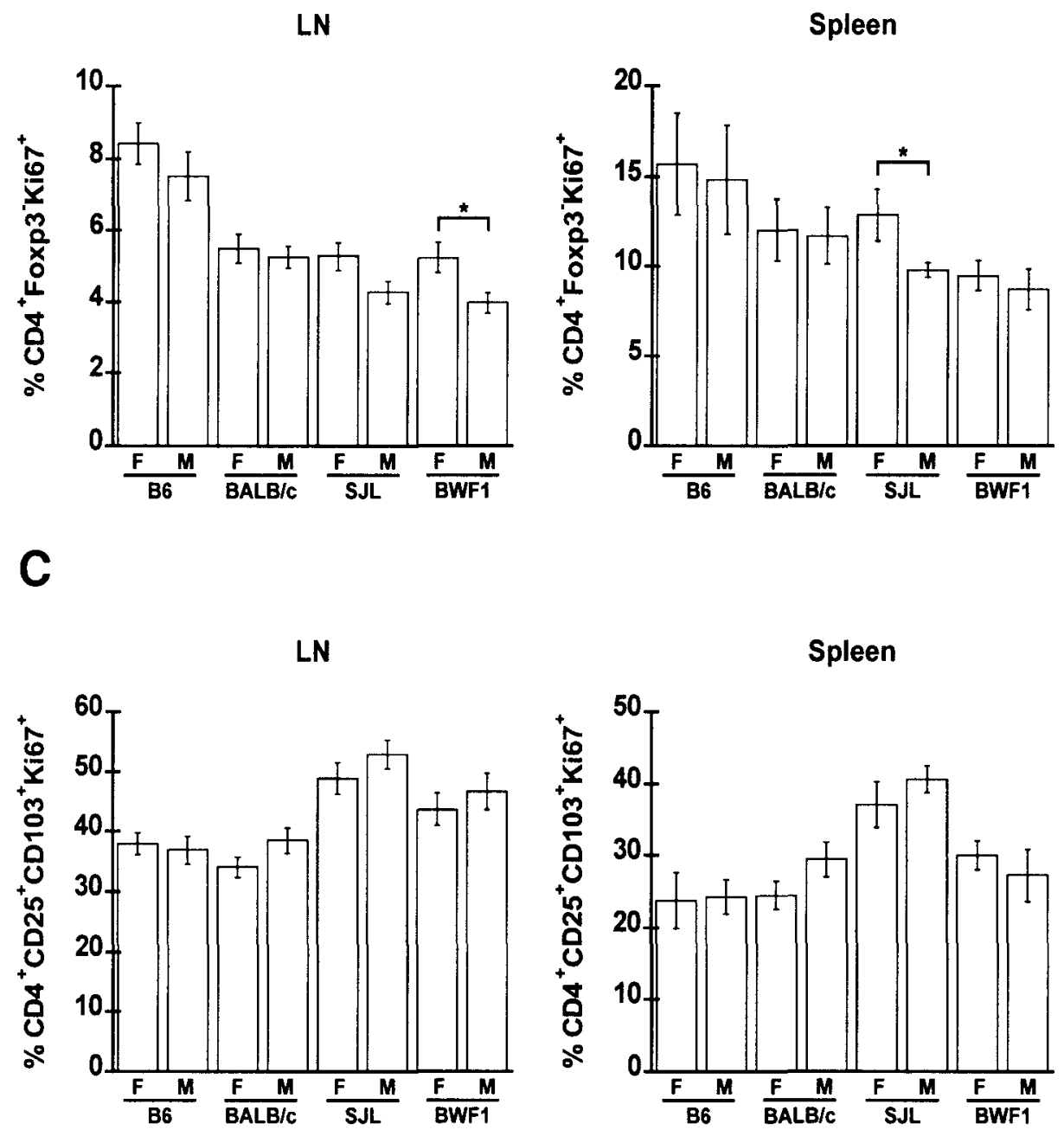

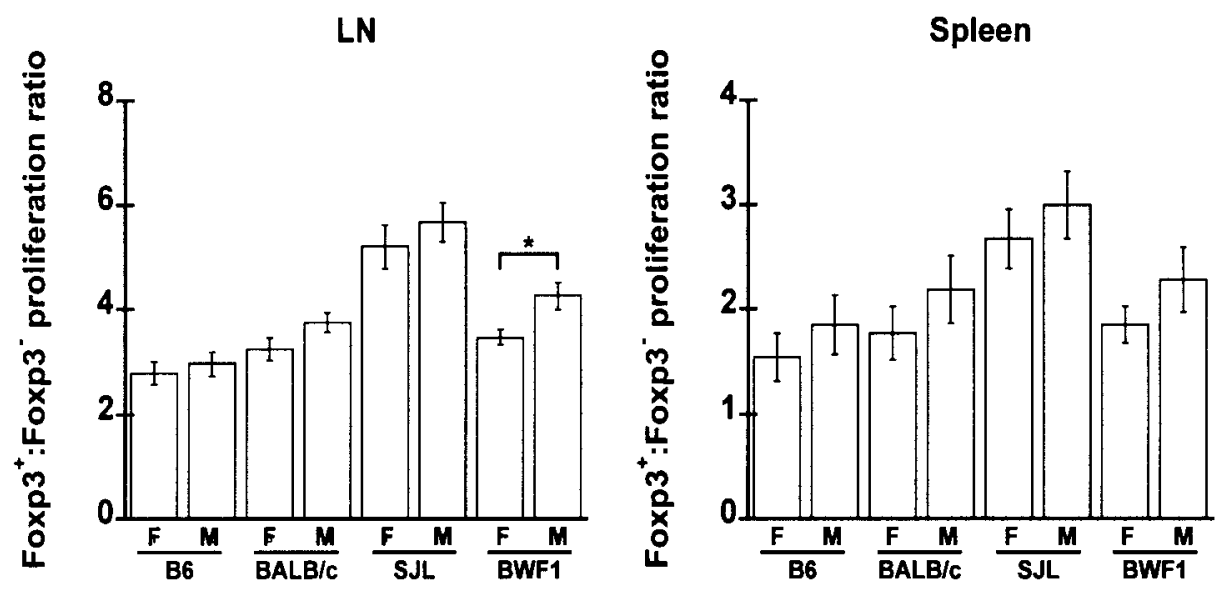

Figure 12. Percentages of proliferating $\mathrm{CD} 4^{+} \mathrm{Foxp} 3^{+}, \mathrm{CD} 4^{+} \mathrm{Foxp} 3^{-}$and $\mathrm{CD}^{+} \mathrm{CD} 25^{+} \mathrm{CD} 103^{+}$cells in the periphery of four strains of mice. Cells from lymph nodes (LN) and spleen of 9-week-old female and male C57BL/6 (B6), BALB/c, SJL and (NZBxNZW)F1 (BWF1) mice were labeled with anti-CD4, anti-CD25, anti-Foxp3, antiCD103 and anti-Ki67 antibodies and analyzed by FACS ${ }^{\oplus}$. (A) Labeled $C D 4^{+}$Foxp $3^{+}$cells were gated and analyzed for the percentages of cells expressing Ki67 in LN and spleen. (B) Labeled $\mathrm{CD}^{+}{ }^{+} \mathrm{Foxp} 3^{-}$cells were gated and analyzed for the percentages of cells expressing Ki67 in $\mathrm{LN}$ and spleen. (C) Labeled $\mathrm{CD} 4^{+} \mathrm{CD} 25^{+} \mathrm{CD} 103^{+}$cells were gated and analyzed for the percentages of cells expressing Ki67 in LN and spleen. (D) Labeled $\mathrm{CD}^{+}{ }^{+} \mathrm{Foxp}^{+}$and $\mathrm{CD} 4^{+} \mathrm{Foxp} 3^{-}$cells were gated and analyzed for the percentages of cells expressing Ki67 in LN and spleen. Proliferation ratios were calculated by dividing the percentage of proliferating $\left(\mathrm{Ki}_{6} 7^{+}\right) \mathrm{CD}^{+} \mathrm{Foxp}^{+}$cells by the percentage of proliferating $\mathrm{CD}^{+}{ }^{+}$Foxp $3^{-}$cells from LN and spleen. Statistical differences were analyzed using a student's $\mathrm{t}$ test or ANOVA and the Tukey-Kramer multiple comparisons test $(\mathrm{n}=15) .{ }^{*}$ $\mathrm{p}<0.05, * * \mathrm{p}<0.005$, and ${ }^{* * *} \mathrm{p}<0.0005$ 


\begin{tabular}{|c|c|c|c|c|c|c|c|c|c|c|}
\hline Strains & Gender & Expt. \#1 & Expt. \#2 & Expt. \#3 & Expt. \#4 & Expt. \#5 & Expt. \#6 & Expt. \#7 & Expt. \#8 & Expt. \#9 \\
\hline \multirow[t]{2}{*}{ C57BL/ 6} & Female & $\begin{array}{c}33.0 \pm \\
2.3\end{array}$ & $\begin{array}{c}35.4 \pm \\
1.5\end{array}$ & $\begin{array}{c}33.4 \pm \\
1.8\end{array}$ & $\begin{array}{c}* * 38.4 \pm \\
0.4\end{array}$ & $\begin{array}{c}37.1 \pm \\
3.1\end{array}$ & $35.1 \pm 1.4$ & $\begin{array}{c}31.5 \pm \\
2.6 \\
\end{array}$ & $\begin{array}{c}37.8 \pm \\
0.8\end{array}$ & $\begin{array}{c}28.8 \pm \\
2.3 \\
\end{array}$ \\
\hline & Male & $\begin{array}{c}25.5 \pm \\
3.1\end{array}$ & $\begin{array}{c}32.9 \pm \\
1.6\end{array}$ & $\begin{array}{c}27.7 \pm \\
2.9\end{array}$ & $\begin{array}{c}34.5 \pm \\
0.8\end{array}$ & $\begin{array}{c}34.1 \pm \\
2.8\end{array}$ & $31.9 \pm 1.0$ & $\begin{array}{c}31.4 \pm \\
1.0\end{array}$ & $\begin{array}{c}37.9 \pm \\
0.8\end{array}$ & $\begin{array}{c}30.5 \pm \\
1.1\end{array}$ \\
\hline \multirow[t]{2}{*}{ BALB/C } & Female & $\begin{array}{c}* * 50.6 \pm \\
1.2\end{array}$ & $\begin{array}{c}49.9 \pm \\
1.9\end{array}$ & $\begin{array}{c}51.4 \pm \\
3.8\end{array}$ & $\begin{array}{c}56.5 \pm \\
0.6\end{array}$ & $\begin{array}{c}55.9 \pm \\
1.0\end{array}$ & $53.4 \pm 1.5$ & $\begin{array}{c}60.4 \pm \\
1.0\end{array}$ & & \\
\hline & Male & $\begin{array}{c}44.1 \pm \\
1.4\end{array}$ & $\begin{array}{c}47.9 \pm \\
2.1\end{array}$ & $\begin{array}{c}41.0 \pm \\
3.1\end{array}$ & $\begin{array}{c}55.5 \pm \\
1.0\end{array}$ & $\begin{array}{c}55.2 \pm \\
0.9\end{array}$ & $52.7 \pm 3.1$ & $\begin{array}{c}58.5 \pm \\
1.0\end{array}$ & & \\
\hline \multirow[t]{2}{*}{ SJL } & Female & $\begin{array}{c}44.2 \pm \\
2.1\end{array}$ & $\begin{array}{c}52.2 \pm \\
1.2\end{array}$ & $\begin{array}{c}36.0 \pm \\
5.1\end{array}$ & $\begin{array}{c}50.6 \pm \\
0.8\end{array}$ & $\begin{array}{c}25.7 \pm \\
3.2\end{array}$ & $24.2 \pm 3.6$ & $\begin{array}{c}49.3 \pm \\
1.3\end{array}$ & $\begin{array}{c}51.9 \pm \\
1.6\end{array}$ & $\begin{array}{c}53.5 \pm \\
0.6\end{array}$ \\
\hline & Male & $\begin{array}{c}49.0 \pm \\
3.7\end{array}$ & $\begin{array}{c}47.6 \pm \\
2.5\end{array}$ & $\begin{array}{c}47.2 \pm \\
3.1\end{array}$ & $\begin{array}{c}50.3 \pm \\
0.6\end{array}$ & $\begin{array}{c}31.6 \pm \\
1.0\end{array}$ & $28.4 \pm 1.6$ & $\begin{array}{c}49.2 \pm \\
1.3\end{array}$ & $\begin{array}{c}51.9 \pm \\
0.9\end{array}$ & $\begin{array}{c}53.1 \pm \\
0.7\end{array}$ \\
\hline \multirow[t]{2}{*}{ BWF1 } & Female & $\begin{array}{c}46.1 \pm \\
6.5\end{array}$ & $\begin{array}{c}59.4 \pm \\
1.9\end{array}$ & $\begin{array}{c}55.3 \pm \\
4.8\end{array}$ & $\begin{array}{c}63.6 \pm \\
0.3\end{array}$ & $\begin{array}{c}65.0 \pm \\
0.7\end{array}$ & $\begin{array}{c}* 62.2 \pm \\
0.9\end{array}$ & $\begin{array}{c}65.5 \pm \\
0.6\end{array}$ & $\begin{array}{c}65.1 \pm \\
0.8\end{array}$ & \\
\hline & Male & $\begin{array}{c}58.5 \pm \\
3.2\end{array}$ & $\begin{array}{c}57.3 \pm \\
3.6\end{array}$ & $\begin{array}{c}55.7 \pm \\
1.0\end{array}$ & $\begin{array}{c}64.2 \pm \\
2.0 \\
\end{array}$ & $\begin{array}{c}62.0 \pm \\
2.0 \\
\end{array}$ & $58.7 \pm 0.3$ & $\begin{array}{c}64.0 \pm \\
0.8\end{array}$ & $\begin{array}{c}64.5 \pm \\
0.6\end{array}$ & \\
\hline
\end{tabular}

\begin{tabular}{|c|c|c|c|c|c|c|c|c|c|c|}
\hline \multicolumn{11}{|c|}{ Table 2B: Spleen $\% \mathrm{CD4}^{+}$} \\
\hline Strains & Gender & Expt. \#1 & Expt. \#2 & Expt. \#3 & Expt. \#4 & Expt. \#5 & Expt. \#6 & Expt. \#7 & Expt. \#8 & Expt. \#9 \\
\hline \multirow[t]{2}{*}{ C57BL/6 } & Female & $7.9 \pm 0.6$ & $\begin{array}{c}16.5 \pm \\
1.0\end{array}$ & $\begin{array}{c}11.6 \pm \\
1.0\end{array}$ & $\begin{array}{c}17.4 \pm \\
0.4\end{array}$ & $\begin{array}{c}17.3 \pm \\
1.1\end{array}$ & $23.7 \pm 4.4$ & $\begin{array}{c}* 19.2 \pm \\
0.5\end{array}$ & $\begin{array}{c}* 19.8 \pm \\
0.4\end{array}$ & $\begin{array}{c}13.4 \pm \\
1.6\end{array}$ \\
\hline & Male & $7.0 \pm 0.7$ & $\begin{array}{c}15.3 \pm \\
0.6\end{array}$ & $\begin{array}{c}12.3 \pm \\
0.5\end{array}$ & $\begin{array}{c}16.6 \pm \\
1.1 \\
\end{array}$ & $\begin{array}{c}18.0 \pm \\
1.3 \\
\end{array}$ & $18.3 \pm 0.5$ & $\begin{array}{c}17.1 \pm \\
0.7\end{array}$ & $\begin{array}{c}21.4 \pm \\
0.5 \\
\end{array}$ & $\begin{array}{c}16.1 \pm \\
0.6\end{array}$ \\
\hline \multirow[t]{2}{*}{ BALB/C } & Female & $\begin{array}{c}12.7 \pm \\
1.6\end{array}$ & $\begin{array}{c}* * 23.4 \pm \\
0.4 \\
\end{array}$ & $\begin{array}{c}17.0 \pm \\
2.1\end{array}$ & $\begin{array}{c}* * 30.8 \pm \\
1.0 \\
\end{array}$ & $\begin{array}{c}29.0 \pm \\
1.0 \\
\end{array}$ & $26.1 \pm 1.0$ & $\begin{array}{c}29.8 \pm \\
1.3 \\
\end{array}$ & & \\
\hline & Male & $\begin{array}{c}11.1 \pm \\
0.7\end{array}$ & $\begin{array}{c}19.4 \pm \\
0.9\end{array}$ & $\begin{array}{c}13.1 \pm \\
1.0\end{array}$ & $\begin{array}{c}25.9 \pm \\
0.8\end{array}$ & $\begin{array}{c}29.7 \pm \\
1.7\end{array}$ & $26.9 \pm 1.2$ & $\begin{array}{c}27.0 \pm \\
0.8\end{array}$ & & \\
\hline \multirow[t]{2}{*}{ SJL } & Female & $\begin{array}{c}13.6 \pm \\
0.7\end{array}$ & $\begin{array}{c}24.2 \pm \\
2.1\end{array}$ & $\begin{array}{c}19.2 \pm \\
1.8 \\
\end{array}$ & $\begin{array}{c}31.6 \pm \\
0.9\end{array}$ & $\begin{array}{c}19.5 \pm \\
1.3\end{array}$ & $19.7 \pm 1.4$ & $\begin{array}{c}28.5 \pm \\
1.0\end{array}$ & $\begin{array}{c}29.7 \pm \\
1.3\end{array}$ & $\begin{array}{c}28.6 \pm \\
1.5\end{array}$ \\
\hline & Male & $\begin{array}{c}13.3 \pm \\
0.7\end{array}$ & $\begin{array}{c}24.5 \pm \\
1.2\end{array}$ & $\begin{array}{c}19.5 \pm \\
1.8 \\
\end{array}$ & $\begin{array}{c}29.1 \pm \\
1.1\end{array}$ & $\begin{array}{c}20.3 \pm \\
0.7\end{array}$ & $18.2 \pm 0.8$ & $\begin{array}{c}27.5 \pm \\
1.0 \\
\end{array}$ & $\begin{array}{c}27.3 \pm \\
0.6\end{array}$ & $\begin{array}{c}27.4 \pm \\
0.7\end{array}$ \\
\hline \multirow[t]{2}{*}{ BWF1 } & Female & $\begin{array}{c}12.3 \pm \\
1.0\end{array}$ & $\begin{array}{c}22.3 \pm \\
1.5\end{array}$ & $\begin{array}{c}17.0 \pm \\
2.5\end{array}$ & $\begin{array}{c}31.4 \pm \\
0.8\end{array}$ & $\begin{array}{c}33.0 \pm \\
0.3\end{array}$ & $26.0 \pm 2.2$ & $\begin{array}{c}* 32.2 \pm \\
0.6\end{array}$ & $\begin{array}{c}31.2 \pm \\
1.8\end{array}$ & \\
\hline & Male & $\begin{array}{c}10.1 \pm \\
2.0 \\
\end{array}$ & $\begin{array}{c}21.0 \pm \\
1.7\end{array}$ & $\begin{array}{c}18.3 \pm \\
2.4\end{array}$ & $\begin{array}{c}28.6 \pm \\
1.6 \\
\end{array}$ & $\begin{array}{c}33.0 \pm \\
1.4\end{array}$ & $29.1 \pm 1.2$ & $\begin{array}{c}29.8 \pm \\
0.7\end{array}$ & $\begin{array}{c}31.9 \pm \\
1.3\end{array}$ & \\
\hline
\end{tabular}




\begin{tabular}{|c|c|c|c|c|c|c|c|c|c|c|}
\hline Strains & Gender & Expt. \# 1 & Expt. \#2 & Expt. \#3 & Expt. \#4 & Expt. \#5 & Expt. \#6 & Expt. \# 7 & Expt. \#8 & Expt. \#9 \\
\hline \multirow[t]{2}{*}{ C57BL/6 } & Female & $5.9 \pm 0.2$ & $6.8 \pm 0.4$ & $5.0 \pm 0.3$ & $7.5 \pm 0.4$ & $\begin{array}{c}* 8.7 \pm \\
0.3\end{array}$ & $\begin{array}{c}* 40.2 \pm \\
0.7\end{array}$ & $\begin{array}{c}* * 8.2 \pm \\
0.5 \\
\end{array}$ & & $\begin{array}{c}6.8 \pm \\
0.9 \\
\end{array}$ \\
\hline & Male & $5.5 \pm 0.1$ & $7.6 \pm 0.2$ & $5.4 \pm 0.3$ & $7.9 \pm 0.2$ & $7.9 \pm 0.2$ & $35.7 \pm 1.6$ & $6.5 \pm 0.4$ & & $9.7 \pm 0.7$ \\
\hline \multirow[t]{2}{*}{ BALB/C } & Female & $9.2 \pm 0.3$ & $9.7 \pm 0.3$ & \begin{tabular}{|c|}
$* * 6.0 \pm$ \\
0.2 \\
\end{tabular} & $\begin{array}{c}12.7 \pm \\
0.6\end{array}$ & & & & & \\
\hline & Male & $8.2 \pm 0.4$ & $\begin{array}{c}10.6 \pm \\
0.2\end{array}$ & $\begin{array}{c}10.2 \pm \\
1.2\end{array}$ & $\begin{array}{c}12.0 \pm \\
0.7\end{array}$ & & & & & \\
\hline \multirow[t]{2}{*}{ SJL } & Female & $\begin{array}{c}* 20.0 \pm \\
1.5\end{array}$ & $\begin{array}{c}* * 20.5 \pm \\
1.7 \\
\end{array}$ & $\begin{array}{c}17.6 \pm \\
0.6\end{array}$ & $\begin{array}{c}* * * 26.3 \\
\pm 0.9 \\
\end{array}$ & $6.1 \pm 0.4$ & $35.0 \pm 4.2$ & $\begin{array}{c}20.5 \pm \\
1.7 \\
\end{array}$ & $\begin{array}{c}22.5 \pm \\
1.4\end{array}$ & \\
\hline & Male & $\begin{array}{c}15.8 \pm \\
1.0\end{array}$ & $\begin{array}{c}17.6 \pm \\
0.6\end{array}$ & $\begin{array}{c}18.2 \pm \\
0.6\end{array}$ & $\begin{array}{c}20.2 \pm \\
0.5\end{array}$ & $8.5 \pm 1.7$ & $24.7 \pm 1.5$ & $\begin{array}{c}17.5 \pm \\
0.9\end{array}$ & $\begin{array}{c}21.9 \pm \\
0.9\end{array}$ & \\
\hline \multirow[t]{2}{*}{ BWF1 } & Female & $8.2 \pm 0.7$ & $8.5 \pm 0.4$ & $8.1 \pm 0.6$ & \begin{tabular}{|c|}
$* * 10.4 \pm$ \\
0.2
\end{tabular} & & & $\begin{array}{c}10.4 \pm \\
0.2\end{array}$ & $\begin{array}{c}12.7 \pm \\
0.4\end{array}$ & \\
\hline & Male & $9.0 \pm 0.4$ & $\begin{array}{c}10.4 \pm \\
0.4\end{array}$ & $7.9 \pm 0.4$ & $\begin{array}{c}12.2 \pm \\
0.4\end{array}$ & & & $\begin{array}{c}11.4 \pm \\
0.6\end{array}$ & $\begin{array}{c}11.9 \pm \\
0.8\end{array}$ & \\
\hline
\end{tabular}

Table 2. Percentages of $\mathrm{CD}^{+}$cells in four strains of mice. Cells from lymph nodes (LN), spleen, and thymus of 8-9-week-old female and male C57BL/6 (B6), BALB/c, SJL and (NZBxNZW)F1 (BWF1) mice were labeled with anti-CD4 antibody and analyzed by FACS $^{\circledast}$. Lymphocytes were gated and analyzed for the percentage of cells expressing CD4 in (A) LN, (B) spleen, and (C) thymus. Statistical differences were analyzed using a student's $t$ test or ANOVA and the Tukey-Kramer multiple comparisons test. ${ }^{*} \mathrm{p}<0.05$, ${ }^{* *} \mathrm{p}<0.005$, and ${ }^{* * *} \mathrm{p}<0.0005$ 


\begin{tabular}{|c|c|c|c|c|c|c|c|c|c|c|}
\hline \multicolumn{11}{|c|}{ Table 3A: LN \% CD4 ${ }^{+}$Foxp $3^{+}$} \\
\hline Strains & Gender & Expt. \#1 & Expt. \#2 & Expt. \#3 & Expt. \#4 & Expt. \#5 & Expt. \#6 & Expt. \#7 & Expt. \#8 & Expt. \#S \\
\hline \multirow[t]{2}{*}{ C57BL/6 } & Female & $\begin{array}{c}* * 8.0 \pm \\
0.2\end{array}$ & $8.2 \pm 0.3$ & $9.1 \pm 0.3$ & $\begin{array}{c}* * 10.0 \pm \\
0.3\end{array}$ & $\begin{array}{c}* 10.1 \pm \\
0.4\end{array}$ & $22.2 \pm 3.1$ & $\begin{array}{c}* 10.1 \pm \\
0.4\end{array}$ & $\begin{array}{c}12.5 \pm \\
0.5\end{array}$ & $8.1 \pm 0.8$ \\
\hline & Male & $9.9 \pm 0.5$ & $8.5 \pm 0.5$ & $9.9 \pm 0.3$ & $\begin{array}{c}12.6 \pm \\
0.5\end{array}$ & $\begin{array}{c}11.7 \pm \\
0.5\end{array}$ & $22.1 \pm 4.6$ & $\begin{array}{c}12.1 \pm \\
0.7\end{array}$ & $\begin{array}{c}14.0 \pm \\
1.0\end{array}$ & $8.0 \pm 1.0$ \\
\hline \multirow[t]{2}{*}{$\mathrm{BALB} / \mathrm{C}$} & Female & $8.4 \pm 0.4$ & $\begin{array}{c}10.2 \pm \\
0.2\end{array}$ & $\begin{array}{c}10.2 \pm \\
0.4 \\
\end{array}$ & $\begin{array}{c}11.7 \pm \\
0.1\end{array}$ & $\begin{array}{c}12.3 \pm \\
0.6\end{array}$ & $* 7.3 \pm 0.7$ & $\begin{array}{c}12.6 \pm \\
0.7\end{array}$ & & \\
\hline & Male & $9.5 \pm 0.5$ & $\begin{array}{c}10.2 \pm \\
0.4\end{array}$ & $9.9 \pm 0.1$ & $\begin{array}{c}11.6 \pm \\
0.5\end{array}$ & $\begin{array}{c}12.9 \pm \\
0.4\end{array}$ & $9.7 \pm$ & $\begin{array}{c}13.3 \pm \\
0.7 \\
\end{array}$ & & \\
\hline \multirow[t]{2}{*}{ SJL } & Female & $6.7 \pm 0.4$ & $7.0 \pm 0.2$ & $7.4 \pm 0.4$ & $9.4 \pm 0.3$ & $8.3 \pm 0.4$ & $13.1 \pm 0.8$ & $\begin{array}{c}12.2 \pm \\
1.0\end{array}$ & $\begin{array}{c}11.0 \pm \\
1.3\end{array}$ & $7.7 \pm 0.2$ \\
\hline & Male & $7.1 \pm 0.2$ & $7.1 \pm 0.4$ & $7.8 \pm 0.2$ & $9.9 \pm 0.3$ & $8.6 \pm 0.6$ & $10.1 \pm 1.2$ & $\begin{array}{c}12.0 \pm \\
0.5\end{array}$ & $\begin{array}{c}12.2 \pm \\
0.4\end{array}$ & $7.5 \pm 0.4$ \\
\hline \multirow[t]{2}{*}{ BWF1 } & Female & $4.8 \pm 0.8$ & $\begin{array}{c}* 4.0 \pm \\
0.1 \\
\end{array}$ & $\begin{array}{c}* * * 3.9 \pm \\
0.1 \\
\end{array}$ & $\begin{array}{c}* * 4.9 \pm \\
0.1 \\
\end{array}$ & $4.5 \pm 0.4$ & $* 4.6 \pm 0.1$ & $\begin{array}{c}* * 6.8 \pm \\
0.4 \\
\end{array}$ & $\begin{array}{c}* * 4.7 \pm \\
0.2\end{array}$ & \\
\hline & Male & $4.1 \pm 0.1$ & $4.5 \pm 0.2$ & $4.8 \pm 0.1$ & $5.5 \pm 0.1$ & $4.9 \pm 0.3$ & $5.3 \pm 0.2$ & $8.8 \pm 0.3$ & $6.1 \pm 0.3$ & \\
\hline
\end{tabular}

\begin{tabular}{|c|c|c|c|c|c|c|c|c|c|c|}
\hline \multicolumn{11}{|c|}{ Table 3B: Spleen \% $\mathrm{CD}^{+} \mathrm{Foxp}^{+}$} \\
\hline Strains & Gender & Expt. \#1 & Expt. \#2 & Expt. \#3 & Expt. \#4 & Expt. \#5 & Expt. \#6 & Expt. \#7 & Expt. \#8 & Expt. \#9 \\
\hline \multirow[t]{2}{*}{ C57BL/6 } & Female & $\begin{array}{c}10.7 \pm \\
0.6\end{array}$ & $7.5 \pm 0.4$ & $\begin{array}{c}11.6 \pm \\
0.3 \\
\end{array}$ & $\begin{array}{c}10.9 \pm \\
0.3\end{array}$ & $\begin{array}{c}11.1 \pm \\
0.7\end{array}$ & $28.5 \pm 6.5$ & $\begin{array}{c}* * 11.4 \pm \\
0.4 \\
\end{array}$ & $\begin{array}{c}13.6 \pm \\
0.4\end{array}$ & $9.9 \pm 0.9$ \\
\hline & Male & $\begin{array}{c}12.5 \pm \\
0.9\end{array}$ & $6.8 \pm 0.4$ & $\begin{array}{c}12.2 \pm \\
0.6\end{array}$ & $\begin{array}{c}10.9 \pm \\
0.2\end{array}$ & $\begin{array}{c}11.1 \pm \\
0.8\end{array}$ & $18.2 \pm 1.9$ & $\begin{array}{c}14.8 \pm \\
0.9\end{array}$ & $\begin{array}{c}13.6 \pm \\
0.5\end{array}$ & $9.6 \pm 0.8$ \\
\hline \multirow[t]{2}{*}{ BALB /c } & Female & $\begin{array}{c}15.9 \pm \\
0.7\end{array}$ & $\begin{array}{c}11.0 \pm \\
0.2\end{array}$ & $\begin{array}{c}18.6 \pm \\
1.0\end{array}$ & $\begin{array}{c}14.0 \pm \\
0.2\end{array}$ & $\begin{array}{c}14.2 \pm \\
0.3\end{array}$ & $\begin{array}{c}11.8 \pm \\
0.7\end{array}$ & $\begin{array}{c}15.3 \pm \\
1.5\end{array}$ & & \\
\hline & Male & $\begin{array}{c}15.5 \pm \\
1.7\end{array}$ & $9.9 \pm 0.5$ & $\begin{array}{c}15.7 \pm \\
1.1\end{array}$ & $\begin{array}{c}14.6 \pm \\
0.6\end{array}$ & $\begin{array}{c}13.4 \pm \\
0.5\end{array}$ & $8.9 \pm 0.7$ & $\begin{array}{c}15.9 \pm \\
0.2\end{array}$ & & \\
\hline \multirow[t]{2}{*}{ SJL } & Female & $\begin{array}{c}22.2 \pm \\
1.5\end{array}$ & $\begin{array}{c}12.4 \pm \\
0.7\end{array}$ & $\begin{array}{c}16.2 \pm \\
0.6\end{array}$ & $\begin{array}{c}* * 17.0 \pm \\
0.4\end{array}$ & $\begin{array}{c}19.3 \pm \\
0.8\end{array}$ & $20.9 \pm 0.8$ & $\begin{array}{c}22.8 \pm \\
0.9\end{array}$ & $\begin{array}{c}21.4 \pm \\
0.7\end{array}$ & $\begin{array}{c}14.9 \pm \\
0.6\end{array}$ \\
\hline & Male & $\begin{array}{c}18.3 \pm \\
1.4\end{array}$ & $\begin{array}{c}12.7 \pm \\
0.8 \\
\end{array}$ & $\begin{array}{c}17.7 \pm \\
0.8\end{array}$ & $\begin{array}{c}18.7 \pm \\
0.3\end{array}$ & $\begin{array}{c}18.2 \pm \\
0.6\end{array}$ & $19.3 \pm 0.6$ & $\begin{array}{c}21.6 \pm \\
0.4\end{array}$ & $\begin{array}{c}22.4 \pm \\
1.5\end{array}$ & $\begin{array}{c}15.3 \pm \\
0.4\end{array}$ \\
\hline \multirow[t]{2}{*}{ BWF1 } & Female & $\begin{array}{c}11.2 \pm \\
1.0\end{array}$ & $\begin{array}{c}* 6.6 \pm \\
0.2\end{array}$ & $9.6 \pm 0.2$ & $9.8 \pm 0.4$ & $8.4 \pm 0.2$ & $12.3 \pm 0.7$ & $7.8 \pm 0.3$ & $9.0 \pm 0.2$ & \\
\hline & Male & $\begin{array}{c}10.4 \pm \\
0.9\end{array}$ & $7.4 \pm 0.3$ & $9.7 \pm 0.7$ & $\begin{array}{c}10.4 \pm \\
0.4\end{array}$ & $8.7 \pm 0.5$ & $11.4 \pm 0.5$ & $8.7 \pm 0.5$ & $8.9 \pm 0.4$ & \\
\hline
\end{tabular}




\begin{tabular}{|c|c|c|c|c|c|c|c|c|c|c|}
\hline \multicolumn{11}{|c|}{ Table 3C: Thymus $\%$ CD4 $^{+}$Foxp $^{+}$} \\
\hline Strains & Gender & Expt. \#1 & Expt. \#2 & Expt. \#3 & Expt. \#4 & Expt. \#5 & Expt. \#6 & Expt. \#7 & Expt. \#8 & Expt. \#9 \\
\hline \multirow[t]{2}{*}{ C57BL/6 } & Female & $1.5 \pm 0.2$ & $3.8 \pm 0.5$ & $2.3 \pm 0.2$ & $3.8 \pm 0.2$ & $2.8 \pm 0.1$ & $9.2 \pm 0.7$ & $\begin{array}{c}* * 6.7 \pm \\
0.2 \\
\end{array}$ & & $0.5 \pm 0.1$ \\
\hline & Male & $1.1 \pm 0.1$ & $3.1 \pm 0.2$ & $2.4 \pm 0.2$ & $4.0 \pm 0.1$ & $2.7 \pm 0.2$ & $11.1 \pm 1.4$ & $5.3 \pm 0.2$ & & $0.4 \pm 0.1$ \\
\hline \multirow[t]{2}{*}{ BALB/C } & Female & $1.8 \pm 0.4$ & $5.6 \pm 0.6$ & $4.0 \pm 0.2$ & \begin{tabular}{|c|}
$* * * 6.8 \pm$ \\
0.3 \\
\end{tabular} & & & & & \\
\hline & Male & $2.0 \pm 0.1$ & $4.9 \pm 0.4$ & $3.1 \pm 0.3$ & $4.5 \pm 0.2$ & & & & & \\
\hline \multirow[t]{2}{*}{ SJL } & Female & $2.5 \pm 0.3$ & $4.7 \pm 0.2$ & $\begin{array}{c}* 3.7 \pm \\
0.2 \\
\end{array}$ & \begin{tabular}{|c|}
$* * 7.5 \pm$ \\
0.3 \\
\end{tabular} & $\begin{array}{c}12.8 \pm \\
0.4\end{array}$ & $5.5 \pm 0.2$ & $7.2 \pm 0.3$ & $7.3 \pm 0.5$ & \\
\hline & Male & $2.6 \pm 0.1$ & $5.8 \pm 0.6$ & $4.7 \pm 0.3$ & $5.6 \pm 0.2$ & $\begin{array}{c}12.9 \pm \\
0.6\end{array}$ & $6.0 \pm 0.2$ & $7.5 \pm 0.3$ & $6.3 \pm 0.4$ & \\
\hline \multirow[t]{2}{*}{ BWF1 } & Female & $3.3 \pm 0.2$ & $5.2 \pm 0.4$ & $4.8 \pm 0.2$ & $6.7 \pm 0.3$ & & & $5.6 \pm 0.2$ & $7.9 \pm 0.3$ & \\
\hline & Male & $3.2 \pm 0.4$ & $4.7 \pm 0.2$ & $5.0 \pm 0.3$ & $6.3 \pm 0.3$ & & & $5.7 \pm 0.2$ & $7.0 \pm 0.3$ & \\
\hline
\end{tabular}

Table 3. Percentages of $\mathrm{CD} 4^{+}$cells that are Foxp $3^{+}$in four strains of mice. Cells from lymph nodes (LN), spleen, and thymus of 8-9-week-old female and male C57BL/6 (B6), BALB/c, SJL and (NZBxNZW)F1 (BWF1) mice were labeled with anti-CD4 and antiFoxp3 antibodies and analyzed by $\mathrm{FACS}^{\circledR}$. Labeled $\mathrm{CD}^{+}$cells were gated and analyzed for the percentages of cells expressing Foxp3 in (A) LN, (B) spleen, and (C) thymus. Statistical differences were analyzed using a student's $t$ test or ANOVA and the TukeyKramer multiple comparisons test. ${ }^{*} \mathrm{p}<0.05,{ }^{* *} \mathrm{p}<0.005$, and ${ }^{* * *} \mathrm{p}<0.0005$. 


\begin{tabular}{|c|c|c|c|c|c|c|c|c|c|c|}
\hline \multicolumn{11}{|c|}{ Table 4A: LN CD4 ${ }^{+}$Foxp $3^{+}$Cell \#s $\left(\times 10^{6}\right)$} \\
\hline Strains & Gender & Expt. \# 1 & Expt. \#2 & Expt. \#3 & Expt. \#4 & Expt. \#5 & Expt. \#6 & Expt. \#7 & Expt. \#8 & Expt. \#9 \\
\hline \multirow[t]{2}{*}{ C57BL/6 } & Female & & $\begin{array}{c}0.400 \pm \\
0.037\end{array}$ & $\begin{array}{c}0.462 \pm \\
0.052\end{array}$ & $\begin{array}{c}0.751 \pm \\
0.060\end{array}$ & $\begin{array}{c}0.714 \pm \\
0.050\end{array}$ & & & & \\
\hline & Male & & $\begin{array}{c}0.467 \pm \\
0.086\end{array}$ & $\begin{array}{c}0.432 \pm \\
0.035\end{array}$ & $\begin{array}{c}0.845 \pm \\
0.126\end{array}$ & $\begin{array}{c}0.611 \pm \\
0.049\end{array}$ & & & & \\
\hline \multirow[t]{2}{*}{$\mathrm{BALB} / \mathrm{C}$} & Female & & $\begin{array}{c}0.741 \pm \\
0.097\end{array}$ & $\begin{array}{c}* 1.123 \pm \\
0.107\end{array}$ & $\begin{array}{c}1.113 \pm \\
0.123\end{array}$ & & & $\begin{array}{c}1.212 \pm \\
0.128\end{array}$ & & \\
\hline & Male & & $\begin{array}{c}0.482 \pm \\
0.055\end{array}$ & $\begin{array}{c}0.578 \pm \\
0.073\end{array}$ & $\begin{array}{c}0.877 \pm \\
0.089\end{array}$ & & & $\begin{array}{c}1.177 \pm \\
0.149 \\
\end{array}$ & & \\
\hline \multirow[t]{2}{*}{ SJL } & Female & & $\begin{array}{c}2.811 \pm \\
0.290 \\
\end{array}$ & $\begin{array}{c}1.461 \pm \\
0.200 \\
\end{array}$ & $\begin{array}{c}* 5.783 \pm \\
0.745 \\
\end{array}$ & $\begin{array}{c}2.683 \pm \\
0.248\end{array}$ & & & & \\
\hline & Male & & $\begin{array}{c}1.824 \pm \\
0.292 \\
\end{array}$ & $\begin{array}{c}1.821 \pm \\
0.099 \\
\end{array}$ & $\begin{array}{c}3.191 \pm \\
0.455 \\
\end{array}$ & $\begin{array}{c}1.841 \pm \\
0.267 \\
\end{array}$ & & & & \\
\hline \multirow[t]{2}{*}{ BWF1 } & Female & & $\begin{array}{c}0.380 \pm \\
0.030\end{array}$ & $\begin{array}{c}* 0.399 \pm \\
0.061 \\
\end{array}$ & $\begin{array}{c}0.785 \pm \\
0.096 \\
\end{array}$ & $\begin{array}{c}0.704 \pm \\
0.083 \\
\end{array}$ & & $\begin{array}{c}1.240 \pm \\
0.151 \\
\end{array}$ & $\begin{array}{c}0.902 \pm \\
0.067\end{array}$ & \\
\hline & Male & & $\begin{array}{c}0.473 \pm \\
0.100\end{array}$ & $\begin{array}{c}0.697 \pm \\
0.035\end{array}$ & $\begin{array}{c}0.696 \pm \\
0.029\end{array}$ & $\begin{array}{c}0.966 \pm \\
0.232\end{array}$ & & $\begin{array}{c}1.516 \pm \\
0.176\end{array}$ & $\begin{array}{c}0.955 \pm \\
0.132\end{array}$ & \\
\hline
\end{tabular}

\begin{tabular}{|c|c|c|c|c|c|c|c|c|c|c|}
\hline \multicolumn{11}{|c|}{ Table 4B: Spleen CD4 ${ }^{+}$Foxp $3^{+}$Cell \#s $\left(\times 10^{6}\right)$} \\
\hline Strains & Gender & Expt. \#1 & Expt. \#2 & Expt. \#3 & Expt. \#4 & Expt. \#5 & Expt. \#6 & Expt. \#7 & Expt. \#8 & Expt. \#9 \\
\hline \multirow[t]{2}{*}{ C57BL/6 } & Female & & \begin{tabular}{|c|}
$1.033 \pm$ \\
0.144 \\
\end{tabular} & \begin{tabular}{|c|}
$0.994 \pm$ \\
0.150 \\
\end{tabular} & $\begin{array}{c}2.094 \pm \\
0.055 \\
\end{array}$ & & & & & \\
\hline & Male & & $\begin{array}{c}0.778 \pm \\
0.100 \\
\end{array}$ & $\begin{array}{c}1.124 \pm \\
0.120 \\
\end{array}$ & $\begin{array}{c}1.914 \pm \\
0.136 \\
\end{array}$ & & & & & \\
\hline \multirow{2}{*}{ BALB /c } & Female & & $\begin{array}{l}* * 1.806 \\
\pm 0.188\end{array}$ & $\begin{array}{c}1.922 \pm \\
0.535\end{array}$ & $\begin{array}{c}* * * 4.882 \\
\pm 0.201\end{array}$ & & & $\begin{array}{c}3.740 \pm \\
0.695\end{array}$ & & \\
\hline & Male & & $\begin{array}{c}0.887 \pm \\
0.064 \\
\end{array}$ & $\begin{array}{c}1.647 \pm \\
0.161\end{array}$ & $\begin{array}{c}3.336 \pm \\
0.131 \\
\end{array}$ & & & $\begin{array}{c}3.639 \pm \\
0.294 \\
\end{array}$ & & \\
\hline \multirow[t]{2}{*}{ SJL } & Female & & $\begin{array}{c}3.238 \pm \\
0.837\end{array}$ & $\begin{array}{c}3.580 \pm \\
0.800\end{array}$ & $\begin{array}{c}7.116 \pm \\
0.435\end{array}$ & & & & & \\
\hline & Male & & $\begin{array}{c}3.158 \pm \\
0.567 \\
\end{array}$ & $\begin{array}{c}3.442 \pm \\
0.582 \\
\end{array}$ & $\begin{array}{c}7.683 \pm \\
0.445 \\
\end{array}$ & & & & & \\
\hline \multirow[t]{2}{*}{ BWF1 } & Female & & \begin{tabular}{|c|}
$0.937 \pm$ \\
0.211 \\
\end{tabular} & $\begin{array}{c}1.140 \pm \\
0.218 \\
\end{array}$ & $\begin{array}{c}* 3.244 \pm \\
0.258 \\
\end{array}$ & $\begin{array}{c}2.335 \pm \\
0.179 \\
\end{array}$ & & $\begin{array}{c}2.213 \pm \\
0.115 \\
\end{array}$ & $\begin{array}{c}* 2.177 \pm \\
0.120 \\
\end{array}$ & \\
\hline & Male & & $\begin{array}{c}1.054 \pm \\
0.175\end{array}$ & $\begin{array}{c}1.017 \pm \\
0.068\end{array}$ & $\begin{array}{c}2.391 \pm \\
0.104\end{array}$ & $\begin{array}{c}2.424 \pm \\
0.080\end{array}$ & & $\begin{array}{c}2.391 \pm \\
0.212\end{array}$ & $\begin{array}{c}1.808 \pm \\
0.084\end{array}$ & \\
\hline
\end{tabular}




\begin{tabular}{|c|c|c|c|c|c|c|c|c|c|c|}
\hline \multicolumn{11}{|c|}{ Table 4C: Thymus CD4 $4^{+}$Foxp $3^{+}$Cell \#s $\left(\times 10^{6}\right)$} \\
\hline Strains & Gender & Expt. \#1 & Expt. \#2 & Expt. \#3 & Expt. \#4 & Expt. \#5 & Expt. \#6 & Expt. \#7 & Expt. \#8 & Expt. \#9 \\
\hline \multirow[t]{2}{*}{ C57BL/6 } & Female & & \begin{tabular}{|c|}
$0.286 \pm$ \\
0.047 \\
\end{tabular} & $\begin{array}{c}0.177 \pm \\
0.032\end{array}$ & $\begin{array}{c}0.456 \pm \\
0.030\end{array}$ & $\begin{array}{c}0.352 \pm \\
0.015 \\
\end{array}$ & & & & \\
\hline & Male & & $\begin{array}{c}0.197 \pm \\
0.025 \\
\end{array}$ & $\begin{array}{c}0.186 \pm \\
0.043 \\
\end{array}$ & $\begin{array}{c}0.362 \pm \\
0.029 \\
\end{array}$ & $\begin{array}{c}0.265 \pm \\
0.044 \\
\end{array}$ & & & & \\
\hline \multirow{2}{*}{ BALB/c } & Female & & $\begin{array}{c}0.364 \pm \\
0.076\end{array}$ & $\begin{array}{c}0.233 \pm \\
0.020\end{array}$ & $\begin{array}{c}* * * 0.892 \\
\pm 0.045\end{array}$ & & & & & \\
\hline & Male & & $\begin{array}{c}0.260 \pm \\
0.029\end{array}$ & $\begin{array}{c}0.173 \pm \\
0.042 \\
\end{array}$ & $\begin{array}{c}0.342 \pm \\
0.030 \\
\end{array}$ & & & & & \\
\hline \multirow[t]{2}{*}{ SJL } & Female & & $\begin{array}{c}0.900 \pm \\
0.271\end{array}$ & $\begin{array}{c}0.784 \pm \\
0.086 \\
\end{array}$ & $\begin{array}{l}* * 1.632 \\
\pm 0.152 \\
\end{array}$ & $\begin{array}{c}* 1.286 \pm \\
0.141 \\
\end{array}$ & & & & \\
\hline & Male & & \begin{tabular}{|c|}
$0.398 \pm$ \\
0.062 \\
\end{tabular} & $\begin{array}{c}0.555 \pm \\
0.161 \\
\end{array}$ & \begin{tabular}{|c|}
$0.897 \pm$ \\
0.088 \\
\end{tabular} & $\begin{array}{c}0.756 \pm \\
0.089 \\
\end{array}$ & & & & \\
\hline \multirow[t]{2}{*}{ BWF1 } & Female & & \begin{tabular}{|c|}
$0.527 \pm$ \\
0.091 \\
\end{tabular} & $\begin{array}{c}0.467 \pm \\
0.064 \\
\end{array}$ & $\begin{array}{l}* * 1.010 \\
\pm 0.136 \\
\end{array}$ & & & $\begin{array}{c}1.039 \pm \\
0.062 \\
\end{array}$ & $\begin{array}{l}* * 1.465 \\
\pm 0.101 \\
\end{array}$ & \\
\hline & Male & & $\begin{array}{c}0.442 \pm \\
0.093\end{array}$ & $\begin{array}{c}0.671 \pm \\
0.208\end{array}$ & $\begin{array}{c}0.487 \pm \\
0.066\end{array}$ & & & $\begin{array}{c}1.030 \pm \\
0.076\end{array}$ & $\begin{array}{c}0.878 \pm \\
0.107\end{array}$ & \\
\hline
\end{tabular}

Table 4. Numbers of $\mathrm{CD} 4^{+}$cells that are Foxp $3^{+}$in four strains of mice. Cells from lymph nodes (LN), spleen, and thymus of 8-9-week-old female and male C57BL/6 (B6), BALB/c, SJL and (NZBxNZW)F1 (BWF1) mice were labeled with anti-CD4 and antiFoxp3 antibodies and analyzed by $\mathrm{FACS}^{\circledast}$. The total numbers of $\mathrm{CD}^{+}$cells that express Foxp3 in (A) lymph nodes, (B) spleen, and (C) thymus are shown. Statistical differences were analyzed using a student's $t$ test or ANOVA and the Tukey-Kramer multiple comparisons test. ${ }^{*} \mathrm{p}<0.05,{ }^{* *} \mathrm{p}<0.005$, and ${ }^{* * *} \mathrm{p}<0.0005$. 


\begin{tabular}{|c|c|c|c|c|c|c|c|c|c|}
\hline \multicolumn{10}{|c|}{ Table 5A: LN CD4+ Cell \#s $\left(\times 10^{6}\right)$} \\
\hline Strains & Gender & Expt. \#1 & Expt. \#2 & Expt. \#3 & Expt. \#4 & Expt. \#5 & Expt. \#6 & Expt. \#7 & Expt. \#8 \\
\hline \multirow[t]{2}{*}{ C57BL/6 } & Female & $4.8 \pm 0.3$ & $5.1 \pm 0.4$ & $7.6 \pm 0.7$ & $7.1 \pm 0.7$ & & & & \\
\hline & Male & $5.0 \pm 0.8$ & $4.3 \pm 0.4$ & $6.7 \pm 0.9$ & $5.3 \pm 0.5$ & & & & \\
\hline \multirow[t]{2}{*}{$\mathrm{BALB} / \mathrm{C}$} & Female & $7.3 \pm 0.8$ & $\begin{array}{c}* * 10.7 \pm \\
0.5 \\
\end{array}$ & $9.5 \pm 1.0$ & & & $9.7 \pm 0.8$ & & \\
\hline & Male & $4.8 \pm 0.5$ & $5.8 \pm 0.7$ & $7.5 \pm 0.6$ & & & $8.8 \pm 0.8$ & & \\
\hline \multirow[t]{2}{*}{ SJL } & Female & $\begin{array}{c}* 40.4 \pm \\
3.4 \\
\end{array}$ & $\begin{array}{c}19.7 \pm \\
1.3\end{array}$ & \begin{tabular}{|c|}
$* * 62.2 \pm$ \\
8.1 \\
\end{tabular} & \begin{tabular}{|c|}
$* * 32.3 \pm$ \\
1.8 \\
\end{tabular} & & & & \\
\hline & Male & $\begin{array}{c}23.4 \pm \\
3.7 \\
\end{array}$ & $\begin{array}{c}23.0 \pm \\
1.9 \\
\end{array}$ & $\begin{array}{c}31.8 \pm \\
3.5 \\
\end{array}$ & $\begin{array}{c}21.0 \pm \\
1.7 \\
\end{array}$ & & & & \\
\hline \multirow[t]{2}{*}{ BWF1 } & Female & $9.5 \pm 0.6$ & $\begin{array}{c}10.4 \pm \\
1.6 \\
\end{array}$ & $\begin{array}{c}16.0 \pm \\
1.8 \\
\end{array}$ & $\begin{array}{c}15.6 \pm \\
1.2\end{array}$ & & $18.1 \pm 1.6$ & $\begin{array}{c}19.2 \pm \\
1.5\end{array}$ & \\
\hline & Male & $\begin{array}{c}10.2 \pm \\
2.1 \\
\end{array}$ & $\begin{array}{c}14.6 \pm \\
1.2 \\
\end{array}$ & $\begin{array}{c}12.6 \pm \\
0.5 \\
\end{array}$ & $\begin{array}{c}19.4 \pm \\
4.1 \\
\end{array}$ & & $17.1 \pm 1.7$ & $\begin{array}{c}15.4 \pm \\
1.4 \\
\end{array}$ & \\
\hline
\end{tabular}

\begin{tabular}{|c|c|c|c|c|c|c|c|c|c|}
\hline \multicolumn{10}{|c|}{ Table 5B: Spleen CD4 ${ }^{+}$Cell \#s $\left(\times 10^{6}\right)$} \\
\hline Strains & Gender & Expt. \#1 & Expt. \# 2 & Expt. \#3 & Expt. \#4 & Expt. \#5 & Expt. \#6 & Expt. \#7 & Expt. \#8 \\
\hline \multirow[t]{2}{*}{ C57BL/6 } & Female & $\begin{array}{c}12.7 \pm \\
1.4\end{array}$ & $8.4 \pm 1.3$ & $\begin{array}{c}19.3 \pm \\
0.7\end{array}$ & & & & & \\
\hline & Male & $\begin{array}{c}11.6 \pm \\
1.5 \\
\end{array}$ & $8.8 \pm 1.1$ & $\begin{array}{c}18.0 \pm \\
1.2\end{array}$ & & & & & \\
\hline \multirow[t]{2}{*}{ BALB/C } & Female & $\begin{array}{c}* 16.6 \pm \\
1.4\end{array}$ & $9.5 \pm 2.4$ & $\begin{array}{c}* * * 35.0 \\
\pm 1.6 \\
\end{array}$ & & & $23.9 \pm 3.1$ & & \\
\hline & Male & $9.5 \pm 0.8$ & $9.5 \pm 0.5$ & $\begin{array}{c}22.9 \pm \\
1.2 \\
\end{array}$ & & & $22.8 \pm 1.7$ & & \\
\hline \multirow[t]{2}{*}{ SJL } & Female & $\begin{array}{c}24.1 \pm \\
5.1\end{array}$ & $\begin{array}{c}21.2 \pm \\
5.2\end{array}$ & $\begin{array}{c}42.1 \pm \\
3.0\end{array}$ & & & & & \\
\hline & Male & $\begin{array}{c}23.1 \pm \\
3.4\end{array}$ & $\begin{array}{c}19.8 \pm \\
4.1 \\
\end{array}$ & $\begin{array}{c}41.2 \pm \\
2.7 \\
\end{array}$ & & & & & \\
\hline \multirow[t]{2}{*}{ BWF1 } & Female & $\begin{array}{c}13.9 \pm \\
3.2\end{array}$ & $\begin{array}{c}11.8 \pm \\
2.0 \\
\end{array}$ & $\begin{array}{c}* * * 33.0 \\
\pm 1.5 \\
\end{array}$ & $\begin{array}{c}27.9 \pm \\
2.2 \\
\end{array}$ & & $29.0 \pm 0.9$ & $\begin{array}{c}24.3 \pm \\
1.7\end{array}$ & \\
\hline & Male & $\begin{array}{c}13.8 \pm \\
1.6\end{array}$ & $\begin{array}{c}10.0 \pm \\
1.0\end{array}$ & $\begin{array}{c}23.0 \pm \\
0.7\end{array}$ & $\begin{array}{c}28.2 \pm \\
2.1\end{array}$ & & $27.3 \pm 1.8$ & $\begin{array}{c}20.6 \pm \\
1.6\end{array}$ & \\
\hline
\end{tabular}




\begin{tabular}{|c|c|c|c|c|c|c|c|c|c|}
\hline \multicolumn{10}{|c|}{ Thym } \\
\hline Strains & Gender & Expt. \#1 & Expt. \#2 & Expt. \#3 & Expt. \#4 & Expt. \#5 & Expt. \#6 & Expt. \#7 & Expt. \#8 \\
\hline \multirow[t]{2}{*}{ C57BL/6 } & Female & $8.2 \pm 0.8$ & $7.1 \pm 1.4$ & $\begin{array}{c}* * 12.1 \pm \\
0.6 \\
\end{array}$ & $\begin{array}{c}* 12.5 \pm \\
0.5 \\
\end{array}$ & & & & \\
\hline & Male & $6.1 \pm 0.5$ & $7.5 \pm 0.5$ & $9.0 \pm 0.6$ & $9.6 \pm 0.9$ & & & & \\
\hline \multirow[t]{2}{*}{ BALB/C } & Female & $6.8 \pm 0.7$ & $5.7 \pm 0.7$ & $\begin{array}{c}* * * 13.2 \\
\pm 0.9 \\
\end{array}$ & & & & & \\
\hline & Male & $5.6 \pm 0.6$ & $5.7 \pm 1.1$ & $7.6 \pm 0.6$ & & & & & \\
\hline \multirow[t]{2}{*}{ SJL } & Female & \begin{tabular}{|c|}
$* 18.7 \pm$ \\
3.9 \\
\end{tabular} & $\begin{array}{c}20.8 \pm \\
1.5\end{array}$ & $\begin{array}{c}* 21.9 \pm \\
2.1\end{array}$ & $\begin{array}{c}* 10.0 \pm \\
1.0\end{array}$ & & & & \\
\hline & Male & $6.2 \pm 0.2$ & $\begin{array}{c}2.1 \pm \\
4.0 \\
\end{array}$ & $\begin{array}{c}16.0 \pm \\
1.2\end{array}$ & $5.9 \pm 0.7$ & & & & \\
\hline \multirow[t]{2}{*}{ BWF1 } & Female & $\begin{array}{c}10.6 \pm \\
0.6\end{array}$ & $9.4 \pm 0.8$ & $\begin{array}{c}* * 14.9 \pm \\
1.5\end{array}$ & & & $18.7 \pm 0.5$ & $\begin{array}{c}* 18.5 \pm \\
1.3\end{array}$ & \\
\hline & Male & $8.8 \pm 1.7$ & $\begin{array}{c}3.0 \pm \\
3.2 \\
\end{array}$ & $7.7 \pm 1.0$ & & & $18.0 \pm 1.2$ & $\begin{array}{c}12.6 \pm \\
1.4\end{array}$ & \\
\hline
\end{tabular}

Table 5. Numbers of $\mathrm{CD} 4^{+}$cells in four strains of mice. Cells from lymph nodes (LN), spleen, and thymus of 8-9-week-old female and male C57BL/6 (B6), BALB/c, SJL and (NZBxNZW)F1 (BWF1) mice were labeled with anti-CD4 antibody and analyzed by FACS $^{\oplus}$. The total numbers of $\mathrm{CD}^{+}$in (A) lymph nodes, (B) spleen, and (C) thymus are shown. Statistical differences were analyzed using a student's $t$ test or ANOVA and the Tukey-Kramer multiple comparisons test. ${ }^{*} \mathrm{p}<0.05,{ }^{* *} \mathrm{p}<0.005$, and ${ }^{* * *} \mathrm{p}<0.0005$. 


\begin{tabular}{|c|c|c|c|c|c|c|c|c|c|c|}
\hline \multicolumn{11}{|c|}{ Table 6A: LN MFI CD4 ${ }^{+}$Foxp $3^{+}$} \\
\hline Strains & Gender & Expt. \#1 & Expt. \# 2 & Expt. \#3 & Expt. \#4 & Expt. \#5 & Expt. \#6 & Expt. \#7 & Expt. \#8 & Expt. \#9 \\
\hline \multirow[t]{2}{*}{ C57BL/ 6} & Female & $\begin{array}{c}126.2 \pm \\
2.9 \\
\end{array}$ & $\begin{array}{c}120.6 \pm \\
2.2 \\
\end{array}$ & $\begin{array}{c}169.4 \pm \\
3.9 \\
\end{array}$ & \begin{tabular}{|c|}
$* 340.4 \pm$ \\
7.0 \\
\end{tabular} & $\begin{array}{c}535.8 \pm \\
6.3 \\
\end{array}$ & $\begin{array}{c}497.1 \pm \\
7.5\end{array}$ & $\begin{array}{c}* 247.5 \pm \\
4.8 \\
\end{array}$ & $\begin{array}{c}312.5 \pm \\
9.0 \\
\end{array}$ & $\begin{array}{c}549.0 \pm \\
7.2 \\
\end{array}$ \\
\hline & ale & $\begin{array}{c}123.2 \pm \\
1.2 \\
\end{array}$ & $\begin{array}{c}121.8 \pm \\
3.6\end{array}$ & $\begin{array}{c}162.2 \pm \\
6.2\end{array}$ & $\begin{array}{c}366.8 \pm \\
7.8 \\
\end{array}$ & $\begin{array}{c}520.1 \pm \\
10.7\end{array}$ & $\begin{array}{c}541.0 \pm \\
36.1\end{array}$ & $\begin{array}{c}227.4 \pm \\
7.1 \\
\end{array}$ & $\begin{array}{c}429.6 \pm \\
97.6 \\
\end{array}$ & $\begin{array}{c}676.3 \pm \\
66.1\end{array}$ \\
\hline \multirow[t]{2}{*}{ BALB/C } & Female & $\begin{array}{c}112.0 \pm \\
2.7 \\
\end{array}$ & $\begin{array}{c}122.4 \pm \\
1.8 \\
\end{array}$ & $\begin{array}{c}153.4 \pm \\
1.8 \\
\end{array}$ & $\begin{array}{c}* 347.0 \pm \\
4.1 \\
\end{array}$ & \begin{tabular}{|c|}
$433.2 \pm$ \\
14.9 \\
\end{tabular} & $\begin{array}{c}407.8 \pm \\
21.8 \\
\end{array}$ & $\begin{array}{c}65.0 \pm \\
1.9 \\
\end{array}$ & & \\
\hline & le & $\begin{array}{c}117.0 \pm \\
2.3\end{array}$ & $\begin{array}{c}123.2 \pm \\
1.9\end{array}$ & $\begin{array}{c}150.0 \pm \\
3.8\end{array}$ & $\begin{array}{c}299.6 \pm \\
14.3\end{array}$ & \begin{tabular}{|c|}
$471.8 \pm$ \\
13.2
\end{tabular} & $\begin{array}{c}421.6 \pm \\
32.9\end{array}$ & $\begin{array}{c}66.8 \pm \\
2.9\end{array}$ & & \\
\hline \multirow[t]{2}{*}{ SJL } & Female & \begin{tabular}{|c|}
$109.8 \pm$ \\
1.8
\end{tabular} & $\begin{array}{c}125.8 \pm \\
2.6\end{array}$ & $\begin{array}{c}147.8 \pm \\
4.8\end{array}$ & $\begin{array}{c}314.7 \pm \\
14.0\end{array}$ & \begin{tabular}{|c|}
$462.0 \pm$ \\
14.8
\end{tabular} & $\begin{array}{c}747.9 \pm \\
37.0\end{array}$ & $\begin{array}{c}304.0 \pm \\
3.7\end{array}$ & $\begin{array}{c}159.8 \pm \\
5.4\end{array}$ & $\begin{array}{c}528.7 \pm \\
8.1\end{array}$ \\
\hline & ale & $\begin{array}{c}112.6 \pm \\
2.2\end{array}$ & $\begin{array}{c}118.6 \pm \\
5.2\end{array}$ & $\begin{array}{c}148.6 \pm \\
3.2 \\
\end{array}$ & $\begin{array}{c}346.2 \pm \\
6.8 \\
\end{array}$ & $\begin{array}{c}450.5 \pm \\
3.7 \\
\end{array}$ & $\begin{array}{c}697.4 \pm \\
37.4\end{array}$ & $\begin{array}{c}323.6 \pm \\
7.9 \\
\end{array}$ & $\begin{array}{c}147.2 \pm \\
6.1\end{array}$ & $\begin{array}{c}558.9 \pm \\
14.4\end{array}$ \\
\hline \multirow[t]{2}{*}{ BWF1 } & Female & \begin{tabular}{|c|}
$119.2 \pm$ \\
2.5 \\
\end{tabular} & $\begin{array}{c}123.8 \pm \\
2.8 \\
\end{array}$ & $\begin{array}{c}* * 152.4 \\
\pm 2.8 \\
\end{array}$ & $\begin{array}{c}342.2 \pm \\
2.0 \\
\end{array}$ & \begin{tabular}{|c|}
$289.0 \pm$ \\
2.7 \\
\end{tabular} & $\begin{array}{c}348.9 \pm \\
15.8\end{array}$ & $\begin{array}{c}160.5 \pm \\
3.8 \\
\end{array}$ & $\begin{array}{c}* * 250.7 \\
\pm 9.5 \\
\end{array}$ & \\
\hline & Male & $\begin{array}{c}119.0 \pm \\
1.1\end{array}$ & $\begin{array}{c}125.6 \pm \\
3.7\end{array}$ & $\begin{array}{c}164.0 \pm \\
1.4\end{array}$ & $\begin{array}{c}333.0 \pm \\
14.1\end{array}$ & \begin{tabular}{|c|}
$287.7 \pm$ \\
9.1
\end{tabular} & $\begin{array}{c}357.9 \pm \\
19.3\end{array}$ & $\begin{array}{c}265.3 \pm \\
73.6\end{array}$ & $\begin{array}{c}386.9 \pm \\
39.3\end{array}$ & \\
\hline
\end{tabular}

\begin{tabular}{|c|c|c|c|c|c|c|c|c|c|c|}
\hline \multicolumn{11}{|c|}{ Table 6B: Spleen MFI CD4 ${ }^{+}$Foxp $^{+}$} \\
\hline Strains & Gender & Expt. \#1 & Expt. \#2 & Expt. \#3 & Expt. \#4 & Expt. \#5 & Expt. \#6 & Expt. \#7 & Expt. \#8 & Expt. \#9 \\
\hline \multirow{2}{*}{ C57BL/6 } & Female & $\begin{array}{c}98.9 \pm \\
2.1\end{array}$ & $\begin{array}{c}93.5 \pm \\
3.7\end{array}$ & $\begin{array}{c}139.4 \pm \\
3.9\end{array}$ & $\begin{array}{c}282.2 \pm \\
11.0\end{array}$ & $\begin{array}{c}* 567.2 \pm \\
11.9\end{array}$ & $\begin{array}{c}885.7 \pm \\
346.1\end{array}$ & $\begin{array}{c}271.4 \pm \\
6.8\end{array}$ & $\begin{array}{c}324.5 \pm \\
8.0\end{array}$ & $\begin{array}{c}547.3 \pm \\
22.8\end{array}$ \\
\hline & ale & $\begin{array}{c}98.6 \pm \\
1.1\end{array}$ & $\begin{array}{c}89.9 \pm \\
1.2\end{array}$ & $\begin{array}{c}126.4 \pm \\
4.3\end{array}$ & $\begin{array}{c}279.8 \pm \\
7.7\end{array}$ & $\begin{array}{c}506.3 \pm \\
22.8\end{array}$ & $\begin{array}{c}538.8 \pm \\
9.3\end{array}$ & $\begin{array}{c}298.1 \pm \\
20.8\end{array}$ & \begin{tabular}{|c|}
$300.3 \pm$ \\
8.2
\end{tabular} & $\begin{array}{c}536.9 \pm \\
7.7\end{array}$ \\
\hline \multirow[t]{2}{*}{$\mathrm{BALB} / \mathrm{C}$} & Female & $\begin{array}{c}99.9 \pm \\
1.5 \\
\end{array}$ & $\begin{array}{c}92.3 \pm \\
2.0\end{array}$ & $\begin{array}{c}131.0 \pm \\
3.7\end{array}$ & $\begin{array}{c}296.1 \pm \\
3.7\end{array}$ & \begin{tabular}{|c|}
$403.4 \pm$ \\
13.2 \\
\end{tabular} & $\begin{array}{c}378.6 \pm \\
4.1\end{array}$ & $\begin{array}{c}64.6 \pm \\
3.5\end{array}$ & & \\
\hline & Male & $\begin{array}{c}100.4 \pm \\
1.5\end{array}$ & $\begin{array}{c}87.0 \pm \\
3.8\end{array}$ & $\begin{array}{c}119.6 \pm \\
4.8\end{array}$ & $\begin{array}{c}267.0 \pm \\
13.0\end{array}$ & $\begin{array}{c}381.2 \pm \\
16.5\end{array}$ & $\begin{array}{c}356.9 \pm \\
19.6\end{array}$ & $\begin{array}{c}62.7 \pm \\
1.0\end{array}$ & & \\
\hline \multirow[t]{2}{*}{ SJL } & Female & $\begin{array}{c}* * * 104.2 \\
\pm 1.0 \\
\end{array}$ & $\begin{array}{c}91.4 \pm \\
2.2 \\
\end{array}$ & $\begin{array}{c}126.2 \pm \\
3.6\end{array}$ & $\begin{array}{c}* 265.2 \pm \\
9.7 \\
\end{array}$ & $\begin{array}{c}456.8 \pm \\
16.1\end{array}$ & $\begin{array}{c}694.6 \pm \\
24.9 \\
\end{array}$ & $\begin{array}{c}301.4 \pm \\
8.2\end{array}$ & $\begin{array}{c}158.0 \pm \\
5.3 \\
\end{array}$ & $\begin{array}{c}560.2 \pm \\
14.7 \\
\end{array}$ \\
\hline & Male & $\begin{array}{c}98.3 \pm \\
0.4\end{array}$ & $\begin{array}{c}84.7 \pm \\
3.2\end{array}$ & $\begin{array}{c}125.8 \pm \\
2.8\end{array}$ & $\begin{array}{c}290.6 \pm \\
3.1\end{array}$ & $\begin{array}{c}440.1 \pm \\
22.8\end{array}$ & $\begin{array}{c}667.7 \pm \\
17.9\end{array}$ & $\begin{array}{c}286.6 \pm \\
6.0\end{array}$ & $\begin{array}{c}153.6 \pm \\
3.0\end{array}$ & $\begin{array}{c}545.1 \pm \\
23.7\end{array}$ \\
\hline \multirow[t]{2}{*}{ BWF1 } & Female & $\begin{array}{c}99.6 \pm \\
1.4\end{array}$ & $\begin{array}{c}86.9 \pm \\
1.8\end{array}$ & $\begin{array}{c}126.4 \pm \\
3.3 \\
\end{array}$ & $\begin{array}{c}253.6 \pm \\
4.4\end{array}$ & $\begin{array}{c}268.5 \pm \\
9.4\end{array}$ & $\begin{array}{c}349.2 \pm \\
11.6\end{array}$ & $\begin{array}{c}209.2 \pm \\
13.0\end{array}$ & $\begin{array}{c}* 227.4 \pm \\
4.6\end{array}$ & \\
\hline & Male & $\begin{array}{c}97.6 \pm \\
1.2\end{array}$ & $\begin{array}{c}94.0 \pm \\
3.1\end{array}$ & $\begin{array}{c}127.0 \pm \\
3.0\end{array}$ & $\begin{array}{c}265.1 \pm \\
4.4\end{array}$ & $\begin{array}{c}286.6 \pm \\
5.0\end{array}$ & $\begin{array}{c}321.5 \pm \\
9.0\end{array}$ & $\begin{array}{c}209.0 \pm \\
9.0\end{array}$ & $\begin{array}{c}349.3 \pm \\
38.7\end{array}$ & \\
\hline
\end{tabular}

Table 6. Per cell expression of Foxp3 on $\mathrm{CD}^{+}$cells in four strains of mice. Cells from lymph nodes (LN) and spleen of 8-9-week-old female and male C57BL/6 (B6), BALB/c, SJL and (NZBxNZW)F1 (BWF1) mice were labeled with anti-CD4 and anti-Foxp3 antibodies and analyzed by $\mathrm{FACS}^{\oplus}$. Labeled $\mathrm{CD} 4^{+}$cells were gated and analyzed for the per cell expression (MFI) of Foxp3 in (A) LN and (B) spleen. Statistical differences were analyzed using a student's t test or ANOVA and the Tukey-Kramer multiple comparisons test. ${ }^{*} \mathrm{p}<0.05,{ }^{* *} \mathrm{p}<0.005$, and ${ }^{* * *} \mathrm{p}<0.0005$ 


\begin{tabular}{|c|c|c|c|c|c|c|c|c|c|c|}
\hline \multicolumn{11}{|c|}{ Table 7A: LN CD4 ${ }^{+} \mathrm{CD} 25^{+} \mathrm{CD}_{103^{+}}$Cell \#s $\left(\times 10^{6}\right)$} \\
\hline Strains & Gender & Expt. \#1 & Expt. \#2 & Expt. \#3 & Expt. \#4 & Expt. \#5 & Expt. \#6 & Expt. \#7 & Expt. \#8 & Expt. \#9 \\
\hline \multirow[t]{2}{*}{ C57BL/6 } & Fernale & & $\begin{array}{c}0.052 \pm \\
0.010\end{array}$ & $\begin{array}{c}0.059 \pm \\
0.008\end{array}$ & $\begin{array}{c}0.085 \pm \\
0.007\end{array}$ & $\begin{array}{c}0.120 \pm \\
0.018\end{array}$ & & & & \\
\hline & Male & & $\begin{array}{c}0.076 \pm \\
0.008\end{array}$ & $\begin{array}{c}0.077 \pm \\
0.005\end{array}$ & $\begin{array}{c}0.136 \pm \\
0.023\end{array}$ & $\begin{array}{c}0.122 \pm \\
0.007\end{array}$ & & & & \\
\hline \multirow[t]{2}{*}{ BALB/C } & Female & & $\begin{array}{c}0.151 \pm \\
0.016\end{array}$ & $\begin{array}{c}0.194 \pm \\
0.030\end{array}$ & $\begin{array}{c}0.107 \pm \\
0.014\end{array}$ & & & $\begin{array}{c}0.105 \pm \\
0.013 \\
\end{array}$ & & \\
\hline & Male & & $\begin{array}{c}0.108 \pm \\
0.013\end{array}$ & $\begin{array}{c}0.131 \pm \\
0.023\end{array}$ & $\begin{array}{c}0.140 \pm \\
0.017\end{array}$ & & & $\begin{array}{c}0.117 \pm \\
0.015\end{array}$ & & \\
\hline \multirow[t]{2}{*}{ SJL } & Female & & $\begin{array}{c}0.398 \pm \\
0.096 \\
\end{array}$ & $\begin{array}{c}0.164 \pm \\
0.014 \\
\end{array}$ & $\begin{array}{c}0.322 \pm \\
0.064\end{array}$ & \begin{tabular}{|c|}
$0.187 \pm$ \\
0.012 \\
\end{tabular} & & & & \\
\hline & Male & & \begin{tabular}{|c|}
$0.227 \pm$ \\
0.035 \\
\end{tabular} & $\begin{array}{c}0.159 \pm \\
0.005 \\
\end{array}$ & $\begin{array}{c}0.255 \pm \\
0.058 \\
\end{array}$ & $\begin{array}{c}0.172 \pm \\
0.038 \\
\end{array}$ & & & & \\
\hline \multirow[t]{2}{*}{ BWF1 } & Female & & \begin{tabular}{|c|}
$0.024 \pm$ \\
0.002 \\
\end{tabular} & $\begin{array}{c}* 0.019 \pm \\
0.003 \\
\end{array}$ & $\begin{array}{c}0.031 \pm \\
0.004\end{array}$ & $\begin{array}{c}0.016 \pm \\
0.002\end{array}$ & & $\begin{array}{c}0.042 \pm \\
0.005\end{array}$ & $\begin{array}{c}0.059 \pm \\
0.007\end{array}$ & \\
\hline & Male & & \begin{tabular}{|c|}
$0.033 \pm$ \\
0.008 \\
\end{tabular} & $\begin{array}{c}0.052 \pm \\
0.007\end{array}$ & $\begin{array}{c}0.039 \pm \\
0.004\end{array}$ & \begin{tabular}{|c|}
$0.024 \pm$ \\
0.005
\end{tabular} & & $\begin{array}{c}0.058 \pm \\
0.008\end{array}$ & \begin{tabular}{|c|}
$0.066 \pm$ \\
0.008
\end{tabular} & \\
\hline
\end{tabular}

\begin{tabular}{|c|c|c|c|c|c|c|c|c|c|c|}
\hline \multicolumn{11}{|c|}{ Table 7B: Spleen $\mathrm{CD}^{+} \mathrm{CD}^{2} 5^{+} \mathrm{CD} 103^{+}$Cell \#s $\left(\times 10^{6}\right)$} \\
\hline Strains & Gender & Expt. \# 1 & Expt. \#2 & Expt. \#3 & Expt. \#4 & Expt. \#5 & Expt. \#6 & Expt. \#7 & Expt. \#8 & Expt. \#9 \\
\hline \multirow[t]{2}{*}{ C57BL/6 } & Female & & $\begin{array}{c}0.026 \pm \\
0.004 \\
\end{array}$ & $\begin{array}{c}0.032 \pm \\
0.006\end{array}$ & $\begin{array}{c}0.095 \pm \\
0.007 \\
\end{array}$ & & & & & \\
\hline & Male & & $\begin{array}{c}0.013 \pm \\
0.004\end{array}$ & $\begin{array}{c}0.047 \pm \\
0.009\end{array}$ & $\begin{array}{c}0.077 \pm \\
0.007\end{array}$ & & & & & \\
\hline \multirow[t]{2}{*}{ BALB/C } & Female & & $\begin{array}{c}* 0.234 \pm \\
0.030\end{array}$ & $\begin{array}{c}0.282 \pm \\
0.077\end{array}$ & $\begin{array}{c}0.470 \pm \\
0.038\end{array}$ & & & $\begin{array}{c}0.224 \pm \\
0.030\end{array}$ & & \\
\hline & Male & & $\begin{array}{c}0.120 \pm \\
0.027 \\
\end{array}$ & $\begin{array}{c}0.203 \pm \\
0.015 \\
\end{array}$ & $\begin{array}{c}0.437 \pm \\
0.023\end{array}$ & & & $\begin{array}{c}0.197 \pm \\
0.016 \\
\end{array}$ & & \\
\hline \multirow[t]{2}{*}{ SJL } & Female & & $\begin{array}{l}* * 0.268 \\
\pm 0.015 \\
\end{array}$ & $\begin{array}{c}0.240 \pm \\
0.035 \\
\end{array}$ & $\begin{array}{c}* 0.248 \pm \\
0.019 \\
\end{array}$ & & & & & \\
\hline & Male & & $\begin{array}{c}0.133 \pm \\
0.025\end{array}$ & $\begin{array}{c}0.153 \pm \\
0.009\end{array}$ & $\begin{array}{c}0.317 \pm \\
0.013 \\
\end{array}$ & & & & & \\
\hline \multirow[t]{2}{*}{ BWF1 } & Female & & $\begin{array}{c}0.036 \pm \\
0.007\end{array}$ & $\begin{array}{c}0.030 \pm \\
0.008 \\
\end{array}$ & $\begin{array}{c}0.086 \pm \\
0.009 \\
\end{array}$ & $\begin{array}{c}0.031 \pm \\
0.010 \\
\end{array}$ & & \begin{tabular}{|c|}
$0.144 \pm$ \\
0.010 \\
\end{tabular} & $\begin{array}{l}* * 0.120 \\
\pm 0.009 \\
\end{array}$ & \\
\hline & Male & & $\begin{array}{c}0.016 \pm \\
0.002 \\
\end{array}$ & $\begin{array}{c}0.032 \pm \\
0.008 \\
\end{array}$ & $\begin{array}{c}0.084 \pm \\
0.011 \\
\end{array}$ & $\begin{array}{c}0.040 \pm \\
0.002 \\
\end{array}$ & & \begin{tabular}{|c|}
$0.123 \pm$ \\
0.007
\end{tabular} & $\begin{array}{c}0.087 \pm \\
0.002\end{array}$ & \\
\hline
\end{tabular}




\begin{tabular}{|c|c|c|c|c|c|c|c|c|c|c|}
\hline \multicolumn{11}{|c|}{ able 7C: Thymus CD4 ${ }^{+} \mathrm{CD} 25^{+} \mathrm{CD} 10$} \\
\hline Strains & Gender & Expt. \#1 & Expt. \#2 & Expt. \#3 & Expt. \#4 & Expt. \#5 & Expt. \#6 & Expt. \#7 & Expt. \#8 & Expt. \#9 \\
\hline \multirow{2}{*}{ C57BL/6 } & Female & & $\begin{array}{c}{ }^{*} 0.022 \pm \\
0.001\end{array}$ & $\begin{array}{c}0.010 \pm \\
0.003\end{array}$ & $\begin{array}{c}0.057 \pm \\
0.006\end{array}$ & & & & & \\
\hline & Male & & $\begin{array}{c}0.011 \pm \\
0.003\end{array}$ & $\begin{array}{c}0.017 \pm \\
0.002\end{array}$ & $\begin{array}{c}0.041 \pm \\
0.004\end{array}$ & & & & & \\
\hline \multirow[t]{2}{*}{ BALB $/ \mathrm{c}$} & Female & & $\begin{array}{c}0.069 \pm \\
0.014\end{array}$ & $\begin{array}{c}* 0.065 \pm \\
0.010\end{array}$ & $\begin{array}{l}* * 0.166 \\
\pm 0.028\end{array}$ & & & & & \\
\hline & Male & & $\begin{array}{c}0.041 \pm \\
0.009\end{array}$ & $\begin{array}{c}0.034 \pm \\
0.003\end{array}$ & $\begin{array}{c}0.063 \pm \\
0.005\end{array}$ & & & & & \\
\hline \multirow[t]{2}{*}{ SJL } & Female & & $\begin{array}{c}0.147 \pm \\
0.060\end{array}$ & $\begin{array}{c}0.107 \pm \\
0.018\end{array}$ & $\begin{array}{c}* 0.176 \pm \\
0.023\end{array}$ & & & & & \\
\hline & Male & & $\begin{array}{c}0.068 \pm \\
0.009\end{array}$ & $\begin{array}{c}0.076 \pm \\
0.025\end{array}$ & $\begin{array}{c}0.101 \pm \\
0.015\end{array}$ & & & & & \\
\hline \multirow[t]{2}{*}{ BWF1 } & Female & & $\begin{array}{c}0.032 \pm \\
0.008\end{array}$ & $\begin{array}{c}0.028 \pm \\
0.003\end{array}$ & $\begin{array}{c}* 0.105 \pm \\
0.021\end{array}$ & & & & & \\
\hline & Male & & $\begin{array}{c}0.040 \pm \\
0.008\end{array}$ & $\begin{array}{c}0.029 \pm \\
0.003\end{array}$ & $\begin{array}{c}0.040 \pm \\
0.007\end{array}$ & & & & & \\
\hline
\end{tabular}

Table 7. Numbers of $\mathrm{CD} 4^{+} \mathrm{CD} 25^{+} \mathrm{CD} 103^{+}$cells in four strains of mice. Cells from lymph nodes (LN), spleen, and thymus of 8-9-week-old female and male C57BL/6 (B6), BALB/c, SJL and (NZBxNZW)F1 (BWF1) mice were labeled with anti-CD4, anti-CD25, and anti-CD103 antibodies and analyzed by FACS ${ }^{\oplus}$. Labeled $\mathrm{CD} 4^{+} \mathrm{CD} 25^{+}$cells $\left(\mathrm{CD} 4^{+} \mathrm{CD} 8^{+} \mathrm{CD} 25^{+}\right.$cells in the thymus) were gated and numbers of cells expressing CD103 were determined in (A) LN, (B) spleen, and (C) thymus. Statistical differences were analyzed using a student's $t$ test or ANOVA and the Tukey-Kramer multiple comparisons test. ${ }^{*} \mathrm{p}<0.05,{ }^{* *} \mathrm{p}<0.005$, and ${ }^{* * *} \mathrm{p}<0.0005$. 


\begin{tabular}{|c|c|c|c|c|c|c|c|c|c|c|}
\hline \multicolumn{11}{|c|}{ Table 8A: LN MFI CD4 ${ }^{+}$CD25 $5^{+} \mathrm{CD} 103^{+}$} \\
\hline Strains & Gender & Expt. \#1 & Expt. \#2 & Expt. \#3 & Expt. \#4 & Expt. \#5 & Expt. \#6 & Expt. \#7 & Expt. \#8 & Expt. \#9 \\
\hline \multirow[t]{2}{*}{ C57BL/6 } & Female & $\begin{array}{c}* * 48.2 \pm \\
2.1\end{array}$ & $\begin{array}{c}82.1 \pm \\
5.1\end{array}$ & $\begin{array}{c}91.1 \pm \\
3.3\end{array}$ & $\begin{array}{c}* 54.3 \pm \\
1.1\end{array}$ & $\begin{array}{c}* 55.8 \pm \\
1.8\end{array}$ & $78.9 \pm 2.0$ & $\begin{array}{c}49.4 \pm \\
0.9\end{array}$ & $\begin{array}{c}* * 43.3 \pm \\
1.3\end{array}$ & $\begin{array}{c}65.8 \pm \\
1.5\end{array}$ \\
\hline & Male & $\begin{array}{c}57.8 \pm \\
1.1\end{array}$ & $\begin{array}{c}90.5 \pm \\
6.6\end{array}$ & $\begin{array}{c}93.8 \pm \\
6.7\end{array}$ & $\begin{array}{c}57.7 \pm \\
0.9\end{array}$ & $\begin{array}{c}61.6 \pm \\
1.3\end{array}$ & $85.2 \pm 3.7$ & $\begin{array}{c}54.4 \pm \\
4.3\end{array}$ & $\begin{array}{c}48.6 \pm \\
0.8\end{array}$ & $\begin{array}{c}62.7 \pm \\
2.3\end{array}$ \\
\hline \multirow[t]{2}{*}{ BALB/C } & Female & $\begin{array}{c}55.4 \pm \\
3.0\end{array}$ & $\begin{array}{c}* * 69.9 \pm \\
2.4\end{array}$ & $\begin{array}{c}94.5 \pm \\
4.9\end{array}$ & $\begin{array}{c}51.6 \pm \\
0.5\end{array}$ & $\begin{array}{c}48.9 \pm \\
1.0\end{array}$ & $\begin{array}{c}* 63.9 \pm \\
3.7\end{array}$ & $\begin{array}{c}273.1 \pm \\
21.0\end{array}$ & & \\
\hline & Male & $\begin{array}{c}54.7 \pm \\
2.4\end{array}$ & $\begin{array}{c}79.5 \pm \\
1.2\end{array}$ & $\begin{array}{c}111.0 \pm \\
7.1\end{array}$ & $\begin{array}{c}55.1 \pm \\
2.4\end{array}$ & $\begin{array}{c}46.8 \pm \\
3.9\end{array}$ & $52.0 \pm 2.5$ & \begin{tabular}{|c|}
$304.3 \pm$ \\
15.7
\end{tabular} & & \\
\hline \multirow[t]{2}{*}{ SJL } & Female & $\begin{array}{c}60.6 \pm \\
4.1 \\
\end{array}$ & \begin{tabular}{|c|}
$* * 78.2 \pm$ \\
4.0 \\
\end{tabular} & $\begin{array}{c}* 146.0 \pm \\
8.5 \\
\end{array}$ & $\begin{array}{c}56.4 \pm \\
1.8 \\
\end{array}$ & $\begin{array}{c}70.2 \pm \\
2.7\end{array}$ & $66.9 \pm 2.8$ & $\begin{array}{c}* * 80.5 \pm \\
0.9\end{array}$ & $\begin{array}{c}* * 58.7 \pm \\
2.7\end{array}$ & $\begin{array}{c}* 49.7 \pm \\
0.9\end{array}$ \\
\hline & Male & $\begin{array}{c}63.8 \pm \\
2.5\end{array}$ & $\begin{array}{c}98.5 \pm \\
1.2\end{array}$ & $\begin{array}{c}119.0 \pm \\
4.5\end{array}$ & $\begin{array}{c}61.2 \pm \\
1.6\end{array}$ & $\begin{array}{c}79.6 \pm \\
5.7\end{array}$ & $76.3 \pm 3.3$ & $\begin{array}{c}95.7 \pm \\
3.2\end{array}$ & $\begin{array}{c}70.6 \pm \\
1.0\end{array}$ & $\begin{array}{c}53.7 \pm \\
1.5\end{array}$ \\
\hline \multirow[t]{2}{*}{ BWF1 } & Female & $\begin{array}{c}* 37.1 \pm \\
1.2\end{array}$ & $\begin{array}{c}49.4 \pm \\
2.5\end{array}$ & $\begin{array}{c}70.4 \pm \\
6.3\end{array}$ & $\begin{array}{c}45.0 \pm \\
0.8\end{array}$ & $\begin{array}{c}29.9 \pm \\
2.7\end{array}$ & $\begin{array}{c}* * * 44.3 \pm \\
0.9\end{array}$ & $\begin{array}{c}422.4 \pm \\
20.1\end{array}$ & $\begin{array}{c}* * 34.4 \pm \\
1.2\end{array}$ & \\
\hline & Male & $\begin{array}{c}44.7 \pm \\
2.2\end{array}$ & $\begin{array}{c}55.7 \pm \\
3.9\end{array}$ & $\begin{array}{c}81.7 \pm \\
3.1\end{array}$ & $\begin{array}{c}44.8 \pm \\
0.5\end{array}$ & $\begin{array}{c}40.1 \pm \\
3.9\end{array}$ & $52.8 \pm 1.2$ & \begin{tabular}{|c|}
$457.9 \pm$ \\
14.8
\end{tabular} & $\begin{array}{c}38.5 \pm \\
0.4\end{array}$ & \\
\hline
\end{tabular}

\begin{tabular}{|c|c|c|c|c|c|c|c|c|c|c|}
\hline \multicolumn{11}{|c|}{ Table 8B: Spleen MFI CD4 ${ }^{+} \mathrm{CD} 5^{+} \mathrm{CD}_{103^{+}}$} \\
\hline Strains & Gender & Expt. \#1 & Expt. \#2 & Expt. \#3 & Expt. \#4 & Expt. \#5 & Expt. \#6 & Expt. \#7 & Expt. \#8 & Expt. \#9 \\
\hline \multirow[t]{2}{*}{ C57BL/6 } & Female & $\begin{array}{c}49.1 \pm \\
6.3\end{array}$ & $\begin{array}{c}* * 60.1 \pm \\
2.5 \\
\end{array}$ & $\begin{array}{c}43.4 \pm \\
1.1\end{array}$ & $\begin{array}{c}31.8 \pm \\
1.0 \\
\end{array}$ & $\begin{array}{c}* * 36.1 \pm \\
1.0 \\
\end{array}$ & $\begin{array}{l}77.6 \pm \\
20.9 \\
\end{array}$ & $\begin{array}{c}31.6 \pm \\
0.7\end{array}$ & $\begin{array}{c}28.1 \pm \\
0.6\end{array}$ & $\begin{array}{c}46.8 \pm \\
10.1\end{array}$ \\
\hline & Male & $\begin{array}{c}43.4 \pm \\
2.5\end{array}$ & $\begin{array}{c}74.5 \pm \\
2.9\end{array}$ & $\begin{array}{c}47.7 \pm \\
4.0\end{array}$ & $\begin{array}{c}33.6 \pm \\
1.4\end{array}$ & $\begin{array}{c}41.0 \pm \\
1.0\end{array}$ & $56.9 \pm 1.6$ & $\begin{array}{c}30.3 \pm \\
1.6\end{array}$ & $\begin{array}{c}28.5 \pm \\
0.4\end{array}$ & $\begin{array}{c}50.3 \pm \\
3.5\end{array}$ \\
\hline \multirow[t]{2}{*}{$\mathbf{B A L B} / \mathbf{C}$} & Female & $\begin{array}{c}* 43.6 \pm \\
1.0\end{array}$ & $\begin{array}{c}* 69.4 \pm \\
1.6\end{array}$ & $\begin{array}{c}73.1 \pm \\
7.1\end{array}$ & $\begin{array}{c}* 35.6 \pm \\
0.2 \\
\end{array}$ & $\begin{array}{c}37.4 \pm \\
0.6\end{array}$ & $34.8 \pm 1.1$ & $\begin{array}{c}145.0 \pm \\
6.1\end{array}$ & & \\
\hline & Male & $\begin{array}{c}50.3 \pm \\
2.2\end{array}$ & $\begin{array}{c}89.7 \pm \\
8.1\end{array}$ & $\begin{array}{c}100.6 \pm \\
18.5\end{array}$ & $\begin{array}{c}36.7 \pm \\
0.3\end{array}$ & $\begin{array}{c}38.1 \pm \\
0.4\end{array}$ & $33.5 \pm 0.4$ & $\begin{array}{c}155.6 \pm \\
13.2\end{array}$ & & \\
\hline \multirow[t]{2}{*}{ SJL } & Female & $\begin{array}{c}45.7 \pm \\
3.5\end{array}$ & $\begin{array}{c}74.2 \pm \\
6.4\end{array}$ & $\begin{array}{c}61.4 \pm \\
3.4\end{array}$ & $\begin{array}{c}* 36.2 \pm \\
0.6\end{array}$ & $\begin{array}{c}46.2 \pm \\
0.7\end{array}$ & $59.5 \pm 4.9$ & $\begin{array}{c}57.2 \pm \\
1.2\end{array}$ & $\begin{array}{c}42.5 \pm \\
0.4\end{array}$ & $\begin{array}{c}35.1 \pm \\
0.6\end{array}$ \\
\hline & Male & $\begin{array}{c}63.8 \pm \\
14.6\end{array}$ & $\begin{array}{c}70.0 \pm \\
7.2\end{array}$ & $\begin{array}{c}52.6 \pm \\
2.3\end{array}$ & $\begin{array}{c}38.0 \pm \\
0.4\end{array}$ & $\begin{array}{c}44.7 \pm \\
2.7\end{array}$ & $50.0 \pm 1.1$ & $\begin{array}{c}60.9 \pm \\
3.6\end{array}$ & $\begin{array}{c}44.1 \pm \\
0.9\end{array}$ & $\begin{array}{c}34.5 \pm \\
0.5\end{array}$ \\
\hline \multirow[t]{2}{*}{ BWF1 } & Female & $\begin{array}{c}37.6 \pm \\
2.3 \\
\end{array}$ & $\begin{array}{c}* 55.2 \pm \\
4.0 \\
\end{array}$ & $\begin{array}{c}46.6 \pm \\
2.3 \\
\end{array}$ & $\begin{array}{c}* * 30.0 \pm \\
0.7 \\
\end{array}$ & $\begin{array}{c}21.7 \pm \\
0.9\end{array}$ & $\begin{array}{c}* 33.4 \pm \\
1.1 \\
\end{array}$ & $\begin{array}{c}350.5 \pm \\
3.4\end{array}$ & $\begin{array}{c}22.5 \pm \\
0.6\end{array}$ & \\
\hline & Male & $\begin{array}{c}41.2 \pm \\
5.6\end{array}$ & $\begin{array}{c}81.0 \pm \\
7.4\end{array}$ & $\begin{array}{c}100.1 \pm \\
49.6\end{array}$ & $\begin{array}{c}32.6 \pm \\
0.3\end{array}$ & $\begin{array}{c}22.3 \pm \\
1.6\end{array}$ & $38.5 \pm 1.0$ & $\begin{array}{c}348.4 \pm \\
11.1\end{array}$ & $\begin{array}{c}23.1 \pm \\
0.6\end{array}$ & \\
\hline
\end{tabular}

Table 8. Per cell expression of $\mathrm{CD} 103$ of $\mathrm{CD}^{+} \mathrm{CD} 25^{+}$cells in four strains of mice. Cells from lymph nodes (LN) and spleen of 8-9-week-old female and male C57BL/6 (B6), BALB/c, SJL and (NZBxNZW)F1 (BWF1) mice were labeled with anti-CD4, anti-CD25, and anti-CD103 antibodies and analyzed by $\mathrm{FACS}^{\oplus}$. Labeled $\mathrm{CD} 4^{+} \mathrm{CD} 25^{+}$cells were gated and analyzed for the per cell expression (MFI) of CD103 in (A) LN and (B) spleen. Statistical differences were analyzed using a student's $t$ test or ANOVA and the TukeyKramer multiple comparisons test. ${ }^{*} \mathrm{p}<0.05,{ }^{* *} \mathrm{p}<0.005$, and ${ }^{* * *} \mathrm{p}<0.0005$. 


\begin{tabular}{|c|c|c|c|c|c|c|c|c|c|c|}
\hline Strains & Gender & Expt. \#1 & Expt. \#2 & Expt. \#3 & Expt. \#4 & Expt. \#5 & Expt. \#6 & Expt. \#7 & Expt. \#8 & Expt. \#9 \\
\hline \multirow[t]{2}{*}{ C57BL/ 6} & Female & $\begin{array}{c}51.0 \pm \\
4.1\end{array}$ & $\begin{array}{c}51.6 \pm \\
3.8\end{array}$ & $\begin{array}{c}47.8 \pm \\
1.4\end{array}$ & & $\begin{array}{c}* 52.4 \pm \\
2.0\end{array}$ & & & & \\
\hline & Male & $\begin{array}{c}54.4 \pm \\
1.8\end{array}$ & $\begin{array}{c}40.6 \pm \\
4.8\end{array}$ & $\begin{array}{c}44.8 \pm \\
3.0\end{array}$ & & $\begin{array}{c}41.4 \pm \\
3.0\end{array}$ & & & & \\
\hline \multirow[t]{2}{*}{ BALB/c } & Female & $\begin{array}{c}34.4 \pm \\
2.0\end{array}$ & $\begin{array}{c}37.2 \pm \\
1.6\end{array}$ & $\begin{array}{c}* * 40.0 \pm \\
1.7\end{array}$ & & & & & & \\
\hline & Male & $\begin{array}{c}33.4 \pm \\
3.3\end{array}$ & $\begin{array}{c}35.4 \pm \\
3.2\end{array}$ & $\begin{array}{c}26.8 \pm \\
3.3\end{array}$ & & & & & & \\
\hline \multirow[t]{2}{*}{ SJL } & Female & $\begin{array}{c}* 53.2 \pm \\
4.7\end{array}$ & $\begin{array}{c}* * 49.4 \pm \\
4.0\end{array}$ & $\begin{array}{c}47.2 \pm \\
3.0\end{array}$ & & $\begin{array}{c}* * * 69.2 \\
\pm 2.0\end{array}$ & & & & \\
\hline & Male & $\begin{array}{c}36.0 \pm \\
3.0\end{array}$ & $\begin{array}{c}28.8 \pm \\
4.0\end{array}$ & $\begin{array}{c}37.2 \pm \\
4.9\end{array}$ & & $\begin{array}{c}35.3 \pm \\
2.8\end{array}$ & & & & \\
\hline \multirow{2}{*}{ BWF1 } & Female & $\begin{array}{c}* 78.4 \pm \\
4.3\end{array}$ & $\begin{array}{c}* * 80.4 \pm \\
3.1\end{array}$ & $\begin{array}{c}* 81.6 \pm \\
4.6\end{array}$ & & & & & $\begin{array}{c}* * * 69.2 \\
\pm 2.5\end{array}$ & \\
\hline & Male & $\begin{array}{c}59.4 \pm \\
4.0\end{array}$ & $\begin{array}{c}66.4 \pm \\
2.0\end{array}$ & $\begin{array}{c}66.6 \pm \\
3.3\end{array}$ & & & & & $\begin{array}{c}47.8 \pm \\
2.6\end{array}$ & \\
\hline
\end{tabular}

\begin{tabular}{|c|c|c|c|c|c|c|c|c|c|c|}
\hline \multicolumn{11}{|c|}{ Table 9B: LN Cell \#s $\left(\times 10^{6}\right)$} \\
\hline Strains & Gender & Expt. \# 1 & Expt. \#2 & Expt. \#3 & Expt. \#4 & Expt. \#5 & Expt. \#6 & Expt. \#7 & Expt. \#8 & Expt. \#9 \\
\hline \multirow[t]{2}{*}{$\mathrm{C57BL} / 6$} & Female & & $\begin{array}{c}17.8 \pm \\
1.9\end{array}$ & $\begin{array}{c}* 16.9 \pm \\
0.9\end{array}$ & $\begin{array}{c}20.8 \pm \\
1.9 \\
\end{array}$ & $\begin{array}{c}21.0 \pm \\
1.3\end{array}$ & & & & \\
\hline & Male & & $\begin{array}{c}19.9 \pm \\
3.4\end{array}$ & $\begin{array}{c}21.5 \pm \\
1.2\end{array}$ & $\begin{array}{c}21.1 \pm \\
3.1\end{array}$ & $\begin{array}{c}17.8 \pm \\
0.4\end{array}$ & & & & \\
\hline \multirow[t]{2}{*}{ BALB / C } & Female & & $\begin{array}{c}* 19.7 \pm \\
1.8\end{array}$ & $\begin{array}{c}22.8 \pm \\
2.3\end{array}$ & $\begin{array}{c}17.8 \pm \\
1.9\end{array}$ & & & $\begin{array}{c}17.2 \pm \\
1.6\end{array}$ & & \\
\hline & Male & & $\begin{array}{c}13.5 \pm \\
1.1\end{array}$ & $\begin{array}{c}19.3 \pm \\
2.7\end{array}$ & $\begin{array}{c}14.4 \pm \\
1.2\end{array}$ & & & $\begin{array}{c}15.8 \pm \\
1.5\end{array}$ & & \\
\hline \multirow[t]{2}{*}{ SJL } & Female & & $\begin{array}{c}* 99.7 \pm \\
11.2\end{array}$ & $\begin{array}{c}56.5 \pm \\
4.0\end{array}$ & $\begin{array}{c}* * 133.9 \\
\pm 17.7\end{array}$ & \begin{tabular}{|c|}
$156.6 \pm$ \\
24.1
\end{tabular} & & & & \\
\hline & Male & & $\begin{array}{c}65.8 \pm \\
3.9\end{array}$ & $\begin{array}{c}51.0 \pm \\
2.6\end{array}$ & $\begin{array}{c}68.2 \pm \\
7.5\end{array}$ & $\begin{array}{c}77.6 \pm \\
4.9\end{array}$ & & & & \\
\hline \multirow[t]{2}{*}{ BWF1 } & Female & & $\begin{array}{c}20.7 \pm \\
1.8\end{array}$ & $\begin{array}{c}26.4 \pm \\
1.2\end{array}$ & $\begin{array}{c}26.4 \pm \\
2.9\end{array}$ & $\begin{array}{c}29.0 \pm \\
1.1\end{array}$ & & $\begin{array}{c}31.3 \pm \\
2.9 \\
\end{array}$ & $\begin{array}{c}30.9 \pm \\
2.4\end{array}$ & \\
\hline & Male & & $\begin{array}{c}22.7 \pm \\
1.8\end{array}$ & $\begin{array}{c}29.7 \pm \\
2.7\end{array}$ & $\begin{array}{c}21.6 \pm \\
0.7\end{array}$ & $\begin{array}{c}34.6 \pm \\
8.5\end{array}$ & & $\begin{array}{c}31.8 \pm \\
3.2\end{array}$ & $\begin{array}{c}25.3 \pm \\
2.5\end{array}$ & \\
\hline
\end{tabular}




\begin{tabular}{|c|c|c|c|c|c|c|c|c|c|c|}
\hline \multicolumn{11}{|c|}{ Table 9C: Spleen Cell \#s $\left(\times 10^{6}\right)$} \\
\hline Strains & Gender & Expt. \#1 & Expt. \#2 & Expt. \#3 & Expt. \#4 & Expt. \#5 & Expt. \#6 & Expt. \#7 & Expt. \#8 & Expt. \#9 \\
\hline \multirow[t]{2}{*}{ C57BL/6 } & Female & & $\begin{array}{r}117.7 \pm \\
9.2 \\
\end{array}$ & \begin{tabular}{|c|}
$107.0 \pm$ \\
4.2 \\
\end{tabular} & \begin{tabular}{|c|}
$120.7 \pm$ \\
4.1 \\
\end{tabular} & & & & & \\
\hline & Male & & $\begin{array}{c}120.3 \pm \\
13.1\end{array}$ & $\begin{array}{c}118.3 \pm \\
8.4\end{array}$ & \begin{tabular}{|c|}
$116.1 \pm$ \\
4.1
\end{tabular} & & & & & \\
\hline \multirow{2}{*}{$\mathrm{BALB} / \mathrm{C}$} & Female & & $\begin{array}{c}117.7 \pm \\
15.4\end{array}$ & $\begin{array}{c}* * 100.3 \\
\pm 5.6\end{array}$ & $\begin{array}{c}* * * 125.0 \\
\pm 1.6\end{array}$ & & & $\begin{array}{c}97.6 \pm \\
12.7\end{array}$ & & \\
\hline & Male & & $\begin{array}{c}93.3 \pm \\
8.0\end{array}$ & \begin{tabular}{|c|}
$134.7 \pm$ \\
4.3
\end{tabular} & $\begin{array}{c}97.4 \pm \\
3.1\end{array}$ & & & $\begin{array}{c}89.0 \pm \\
6.9\end{array}$ & & \\
\hline \multirow[t]{2}{*}{ SJL } & Female & & $\begin{array}{c}192.3 \pm \\
11.9\end{array}$ & $\begin{array}{c}* 161.7 \pm \\
9.8\end{array}$ & $\begin{array}{c}152.3 \pm \\
8.5\end{array}$ & & & & & \\
\hline & Male & & $\begin{array}{c}199.0 \pm \\
26.2\end{array}$ & \begin{tabular}{|c|}
$252.3 \pm$ \\
20.1 \\
\end{tabular} & \begin{tabular}{|c|}
$161.8 \pm$ \\
3.5 \\
\end{tabular} & & & & & \\
\hline \multirow[t]{2}{*}{ BWF1 } & Female & & $\begin{array}{c}145.3 \pm \\
14.7\end{array}$ & $\begin{array}{c}91.3 \pm \\
7.7\end{array}$ & $\begin{array}{c}* 116.5 \pm \\
5.9\end{array}$ & $\begin{array}{c}90.2 \pm \\
6.9\end{array}$ & & \begin{tabular}{|c|}
$105.6 \pm \pm$ \\
3.9
\end{tabular} & $\begin{array}{c}* 82.1 \pm \\
3.3\end{array}$ & \\
\hline & Male & & $\begin{array}{c}104.0 \pm \\
16.1\end{array}$ & $\begin{array}{c}95.7 \pm \\
4.9\end{array}$ & $\begin{array}{c}92.5 \pm \\
7.1\end{array}$ & $\begin{array}{c}92.4 \pm \\
4.4\end{array}$ & & $\begin{array}{c}107.0 \pm \\
8.0\end{array}$ & $\begin{array}{c}67.6 \pm \\
4.0\end{array}$ & \\
\hline
\end{tabular}

\begin{tabular}{|c|c|c|c|c|c|c|c|c|c|c|}
\hline \multicolumn{11}{|c|}{ Table 9D: Thymus Cell \#s $\left(\times 10^{6}\right)$} \\
\hline Strains & Gender & Expt. \#1 & Expt. \#2 & Expt. \#3 & Expt. \#4 & Expt. \#5 & Expt. \#6 & Expt. \#7 & Expt. \#8 & Expt. \#9 \\
\hline \multirow[t]{2}{*}{ C57BL/6 } & Female & & $\begin{array}{c}* * 146.3 \\
\pm 6.2 \\
\end{array}$ & $\begin{array}{c}160.0 \pm \\
12.9\end{array}$ & $\begin{array}{c}* * 180.9 \\
\pm 8.9\end{array}$ & $\begin{array}{c}153.2 \pm \\
10.0\end{array}$ & & & & \\
\hline & Male & & $\begin{array}{c}93.3 \pm \\
8.3 \\
\end{array}$ & $\begin{array}{c}157.2 \pm \\
14.1 \\
\end{array}$ & $\begin{array}{c}128.7 \pm \\
8.5 \\
\end{array}$ & $\begin{array}{c}129.4 \pm \\
10.7 \\
\end{array}$ & & & & \\
\hline \multirow[t]{2}{*}{ BALB/C } & Female & & $\begin{array}{c}* 89.2 \pm \\
4.0\end{array}$ & $\begin{array}{c}115.2 \pm \\
13.3 \\
\end{array}$ & $\begin{array}{c}* * 119.5 \\
\pm 11.7 \\
\end{array}$ & & & & & \\
\hline & Male & & $\begin{array}{c}66.7 \pm \\
5.8\end{array}$ & $\begin{array}{c}66.8 \pm \\
21.2\end{array}$ & $\begin{array}{c}72.6 \pm \\
6.0 \\
\end{array}$ & & & & & \\
\hline \multirow[t]{2}{*}{ SJL } & Female & & $\begin{array}{c}122.7 \pm \\
33.1\end{array}$ & $\begin{array}{c}129.6 \pm \\
13.8\end{array}$ & $\begin{array}{c}93.9 \pm \\
10.6\end{array}$ & $\begin{array}{c}* * 182.4 \\
\pm 13.6\end{array}$ & & & & \\
\hline & Male & & $\begin{array}{c}45.0 \pm \\
1.6\end{array}$ & $\begin{array}{c}77.6 \pm \\
23.6 \\
\end{array}$ & $\begin{array}{c}89.3 \pm \\
8.9\end{array}$ & $\begin{array}{c}86.0 \pm \\
18.7\end{array}$ & & & & \\
\hline \multirow[t]{2}{*}{ BWF1 } & Female & & $\begin{array}{c}158.0 \pm \\
10.8\end{array}$ & \begin{tabular}{|c|}
$152.0 \pm$ \\
22.7
\end{tabular} & $\begin{array}{c}* * 158.4 \\
\pm 14.3 \\
\end{array}$ & & & \begin{tabular}{|c|}
$188.2 \pm$ \\
6.2 \\
\end{tabular} & $\begin{array}{c}* 148.2 \pm \\
9.6 \\
\end{array}$ & \\
\hline & Male & & $\begin{array}{c}108.8 \pm \\
22.7\end{array}$ & $\begin{array}{c}180.0 \pm \\
35.6\end{array}$ & $\begin{array}{c}75.0 \pm \\
10.4\end{array}$ & & & $\begin{array}{c}166.3 \pm \\
13.4\end{array}$ & \begin{tabular}{|c|}
$108.4 \pm$ \\
9.3
\end{tabular} & \\
\hline
\end{tabular}

Table 9. Thymic weights and cell numbers in thymus, lymph nodes and spleen in four strains of mice. Thymus, lymph nodes and spleen were collected from 8-9-week-old female and male $\mathrm{C} 57 \mathrm{BL} / 6, \mathrm{BALB} / \mathrm{c}, \mathrm{SJL}$ and $\mathrm{BWF} 1$ mice and weights or cell numbers determined. Statistical differences were analyzed using a student's t test or ANOVA and the Tukey-Kramer multiple comparisons test. ${ }^{*} \mathrm{p}<0.05,{ }^{* *} \mathrm{p}<0.005$, and ${ }^{* * *} \mathrm{p}<0.0005$. 


\section{SPECIFIC AIM III}

\section{Assessing regulatory $\mathbf{T}$ cell changes throughout disease progression in lupus-prone (NZBxNZW)F1 mice.}

The (NZBxNZW)F1 (BWF1) strain of mice is used as a model of systemic lupus erythematosus in which females spontaneously develop disease $(66,67)$. Antibodies against self-antigens, such as dsDNA and histones, are produced and associate with complement to form immune complexes (80). These antibodies can be detected in the serum at approximately 16 weeks of age in female BWF 1 mice in our facility. Immune complexes deposit in the kidney glomeruli and cause kidney failure (80). Infiltration of T cells into the kidney has been shown to be necessary for end-stage kidney disease development (91). Glomerulonephritis is detected by the presence of protein in urine. We begin analyzing for protein in the urine when BWF 1 mice are approximately 28 weeks of age in our facility. Male BWF1 mice also develop antibodies, but they do so later than females, and rarely develop full-blown SLE/glomerulonephritis. In our facility, approximately $50 \%$ of female BWF 1 mice have developed disease by 32 weeks of age, while $0 \%$ of males have disease at this timepoint (Figure 13). Accumulating evidence indicates that regulatory $\mathrm{T}$ cells (Tregs) play an important role in controlling autoimmune disease (123). Here we have investigated the differences in Treg populations between females and males throughout disease progression to determine whether differences in these cells were associated with susceptibility to disease. 


\section{Sick female BWF1 mice had no defect in suppressive function in vitro, and had}

higher percentages of $\mathrm{CD4}^{+} \mathrm{Foxp}^{+}$cells in the periphery than age-matched non-sick females and males.

BWF1 mice were considered "sick" when protein levels in urine reached $\geq 300 \mathrm{mg} / \mathrm{dL}$ and were maintained for two consecutive weeks. Regulatory T cells have been shown to be important in controlling autoimmune disease (123), so we hypothesized that perhaps there was some inherent defect in sick female Treg suppressive function allowing for disease development and progression. We compared suppressive function of Tregs from sick females, non-sick females, and males in a standard in vitro suppression assay. We co-cultured bead-purified $\mathrm{CD} 4^{+} \mathrm{CD} 25^{+}$cells from age-matched sick females, non-sick females, and males at varying ratios with male $\mathrm{CD} 4^{+} \mathrm{CD} 25^{-}$responder $\mathrm{T}$ cells, irradiated male spleen cells for APC, and anti-CD3. We found no differences in the suppressive function of $\mathrm{CD} 4^{+} \mathrm{CD} 25^{+}$cells in vitro between sick females, non-sick females, and males (Figure 14A).

In another mouse model of systemic lupus erythematosus derived from the BWF1 strain, Morel and colleagues also found no defect in the suppressive function of sick female Tregs, but did find that sick female $\mathrm{CD} 4^{+} \mathrm{CD} 25^{-}$responder cells were resistant to suppression $(115,116)$. This resistance to suppression was mediated by increased IL-6 production by bone marrow-derived DC $(115,116)$. With this in mind, we compared $\mathrm{CD} 4^{+} \mathrm{CD} 25^{-}$responder cell susceptibility to suppression as well as the ability of APC to support suppression between age-matched sick females, non-sick females, and males. We found that sick female $\mathrm{CD} 4^{+} \mathrm{CD} 25^{-}$responder cells were suppressed at similar levels to 
non-sick female and male $\mathrm{CD} 4^{+} \mathrm{CD} 25^{-}$responder cells (Figure 14B). Morel and colleagues found excess IL- 6 production by DC caused $\mathrm{CD} 4^{+} \mathrm{CD} 25^{-}$responder cells to become resistant to suppression in vitro $(115,116)$. However, we found no defect in the ability of sick female APC to support suppression compared to age-matched non-sick female and male APC, i.e., APC from sick females did not confer resistance to suppression on responder cells (Figure 14C). These data together indicate that there are no inherent defects in the ability of sick $\mathrm{CD} 4^{+} \mathrm{CD} 25^{-}$responder cells to be suppressed or in the ability of APC from sick female mice to support suppression of sick female Tregs to suppress disease.

Foxp3, the best Treg marker to date, is a transcription factor necessary for Treg function (127). Interestingly, 32-36-week-old sick females had significantly higher percentages of $\mathrm{CD}^{+} \mathrm{T}$ cells that were Foxp3 ${ }^{+}$in lymph nodes (LN) and spleen than agematched non-sick females and males, whose percentages in $\mathrm{LN}$ and spleen were similar to one another (Figure 15A). Sick females also had higher total $\mathrm{CD} 4^{+} \mathrm{Foxp} 3^{+}$cell numbers than age-matched non-sick females and males in LN (Figure 15B). This is consistent with higher total cell numbers in general in LN and spleen in sick female mice compared to age-matched non-sick female and male total cell numbers (Table 10). We found similar differences in the percentages of $\mathrm{CD} 4^{+}$cells that express $\mathrm{CD} 25$ as we did in percentages of $\mathrm{CD}^{+}$cells that express Foxp3, i.e. sick females had the highest percentages (Figure 15C). However, we found no difference in per cell Foxp3 expression by $\mathrm{CD} 4{ }^{+} \mathrm{CD} 25^{+}$cells between sick females and age-matched non-sick females and males in LN or spleen (Figure 15D, Table 11). Thus, sick female BWF1 mice have higher 
percentages of Tregs than age-matched non-sick females and males, and these cells are functional suppressors in vitro.

Sick females had a higher percentage of $\mathrm{CD4}^{+} \mathrm{CD25}^{+} \mathrm{CD} 13^{+}$cells than age-matched non-sick females and males with no defect in suppressive function in vitro.

A subset of very potent Tregs expresses the integrin, $\alpha_{E} \beta_{7}(C D 103)$ (207). CD103 is thought to be involved in retention of this subset of Tregs at sites of inflammation (212). $\mathrm{CD} 103^{+}$Tregs are more potent suppressors than CD103- Tregs, both in vitro and in vivo, and are considered an effector/memory subset of Tregs $(149,207,210,211)$. This subset of $\mathrm{CD}_{103^{+}}$Tregs has been shown to be effective at controlling autoimmune/inflammatory diseases such as wasting disease and colitis (211). As we did with the $\mathrm{CD} 4{ }^{+} \mathrm{CD} 25^{+}$cells, we compared the suppressive function of $\mathrm{CD}^{+} \mathrm{CD} 25^{+} \mathrm{CD} 103^{+}$cells between age-matched sick females, non-sick females, and males using a standard in vitro suppression assay. We co-cultured $\mathrm{CD} 4^{+} \mathrm{CD} 25^{+} \mathrm{CD}_{103}{ }^{+}$ cells sorted to $>95 \%$ purity from sick females, non-sick females, and males at varying ratios with male $\mathrm{CD} 4^{+} \mathrm{CD} 25^{-}$responder cells, male irradiated spleen cells as APCs, and anti-CD3. We found no significant difference in suppressive ability of $\mathrm{CD}^{+} \mathrm{CD} 25^{+} \mathrm{CD} 103^{+}$cells between age-matched sick females, non-sick females, and males (Figure 16D).

Consistent with data found for $\mathrm{CD} 4^{+} \mathrm{Foxp}^{+}$cells as a whole, we found that 32-36 week-old sick female mice had significantly higher percentages and total cell numbers of the potent $\mathrm{CD} 4^{+} \mathrm{CD} 25^{+} \mathrm{CD} 103^{+}$cells than age-matched non-sick females and males in $\mathrm{LN}$ and spleen (Figure 16A, Table 12). Sick females had similar per cell CD103 expression 
on $\mathrm{CD}^{+} \mathrm{CD} 25^{+} \mathrm{CD} 103^{+}$cells as non-sick females and males in $\mathrm{LN}$ and spleen (Figs. 16B $\& \mathrm{C}$ ). Thus, there were no inherent defects in $\mathrm{CD} 4^{+} \mathrm{CD} 25^{+} \mathrm{CD} 103^{+}$suppressive function in sick females, and the $\mathrm{CD} 4^{+} \mathrm{CD} 25^{+} \mathrm{CD} 103^{+}$cell population was actually increased in sick BWF1 mice.

Although it is not clear whether the thymus is actually a major source of $\mathrm{CD} 4^{+} \mathrm{CD} 25^{+} \mathrm{CD} 103^{+}$cells, we next investigated whether sick females had defects in thymic production of these cells. We found that, as in the periphery, sick females had higher percentages of both $\mathrm{CD} 4^{+} \mathrm{Foxp} 3^{+}$and $\mathrm{CD} 4^{+} \mathrm{CD} 25^{+} \mathrm{CD} 103^{+}$subsets in the thymus (Figure 17). All types of $T$ cells can traffic into the thymus from the periphery (259), so while our data did not suggest a defect in thymic $\mathrm{CD} 4^{+} \mathrm{CD} 25^{+} \mathrm{CD} 103^{+}$cell production in sick females, it does not rule out the possibility that $\mathrm{CD} 4^{+} \mathrm{CD} 25^{+} \mathrm{CD} 103^{+}$cells from the periphery, in which sick females have a higher percentages of $\mathrm{CD} 4{ }^{+} \mathrm{CD} 25^{+} \mathrm{CD} 103^{+}$cells, are trafficking back into the thymus.

\section{Sick female Tregs were unable to control effector $\mathrm{T}$ cell proliferation in vivo.}

To determine whether differences in homeostatic proliferation were responsible for differences in peripheral Treg percentages between 32-36-week-old sick female, nonsick female, and male BWF1 mice, we stained LN and spleen cells with an antibody against Ki67, a marker for proliferating cells. Although sick females had higher percentages of both $\mathrm{CD} 4^{+} \mathrm{Foxp}^{+}$and $\mathrm{CD} 4^{+} \mathrm{CD} 25^{+} \mathrm{CD} 103^{+}$cells in $\mathrm{LN}$ and spleen (Figure $15 \mathrm{~A}, 16 \mathrm{~A}$ ), their $\mathrm{CD} 4^{+} \mathrm{Foxp}^{+}$and $\mathrm{CD} 4^{+} \mathrm{CD} 25^{+} \mathrm{CD} 103^{+}$cells did not proliferate more in vivo than in age-matched non-sick females and males (Figure 18A, 18C). However, $\mathrm{CD}^{+}{ }^{+}$Foxp $3^{-}$effector T cells did proliferate significantly more in sick female $\mathrm{LN}$ and 
tended to proliferate more in spleen than in age-matched non-sick females and males (Figure 18B). The Ki67 proliferation data were confirmed with BrdU staining. Further analysis showed that the Foxp $3^{+}$:Foxp $3^{-}$proliferation ratio was significantly lower in both the LN and spleen of sick female mice by comparison to both non-sick female and male BWF1 mice (Figure 18D). These data suggest two things. First, the high percentages of $\mathrm{CD} 4^{+} \mathrm{Foxp}^{+}$and $\mathrm{CD} 4^{+} \mathrm{CD} 25^{+} \mathrm{CD} 103^{+}$cells found in the periphery of sick female BWF1 mice are not due to either increased proliferation of these cells or a decreased proliferation of the $\mathrm{CD} 4^{+}$Foxp $3^{-}$cells. Secondly, the increased proliferation of the $\mathrm{CD}^{+}{ }^{+}$Foxp $3^{-}$cells in sick female mice suggest that sick female Tregs, while able to suppress proliferation of $\mathrm{CD} 4^{+} \mathrm{CD} 25^{-}$cells in vitro (Figure 14A), appear unable to suppress proliferation of the same population in vivo.

\section{Sick female Tregs were able to traffic to kidney LN}

We next examined the ability of sick female Tregs to traffic to sites where their suppressive function would likely be needed in late stage disease. $\mathrm{T}$ cell infiltration into the kidney is necessary for end stage kidney disease (91), so the lymphoid organs draining the kidney may be an important site for Tregs to carry out their suppressive function. For this purpose, we analyzed kidney $\mathrm{LN}$ for the presence of $\mathrm{CD} 4^{+} \mathrm{Foxp} 3^{+}$and $\mathrm{CD} 4^{+} \mathrm{CD} 25^{+} \mathrm{CD} 103^{+}$cells. We found that sick females had higher percentages of both $\mathrm{CD}^{+}{ }^{+} \mathrm{Foxp}^{+}$and $\mathrm{CD} 4^{+} \mathrm{CD} 25^{+} \mathrm{CD} 103^{+}$cells in the kidney $\mathrm{LN}$ compared to age-matched non-sick females and males (Figure 19), suggesting that the Tregs were getting to the site where the Treg targets, the kidney-specific effector T cells, would likely be induced. 
However, these data do not rule out the possibility that the Tregs are not infiltrating the kidney itself where they may also be required to suppress pathogenic $\mathrm{T}$ cell function.

Downregulation of CD62L is required for T cell egress from LN (260). $\mathrm{CD}^{+} \mathrm{CD} 25^{+} \mathrm{CD} 103^{+}$cells are known as a memory/effector subset of Tregs that can traffic to and are retained at sites of inflammation $(210,212)$. If these $\mathrm{CD}_{10} 3^{+}$Tregs are unable to downregulate $\mathrm{CD} 62 \mathrm{~L}$ and leave the $\mathrm{LN}$, they may be unable to traffic to inflammatory sites, which may prevent them from performing important regulatory functions and thus, protect from disease. We evaluated CD62L expression on $\mathrm{CD}^{+} \mathrm{CD} 25^{+} \mathrm{CD} 103^{+}$Tregs, and found that sick females actually had lower percentages of $\mathrm{CD} 4^{+} \mathrm{CD} 25^{+} \mathrm{CD} 103^{+} \mathrm{CD} 62 \mathrm{~L}^{\text {hi }}$ cells and, therefore, more $\mathrm{CD} 62^{\text {lo }}$ cells than age-matched non-sick females and males in both LN and spleen (Figure 20), suggesting that this population can and does downregulate CD62L and is, therefore, not "stuck" in the LN because of its inability to properly regulate CD62L expression.

\section{Regulatory $T$ cell percentages change with disease progression in BWF1 mice.}

As discussed above, we found that sick females had much higher percentages and numbers of both $\mathrm{CD} 4^{+} \mathrm{Foxp} 3^{+}$and $\mathrm{CD} 4^{+} \mathrm{CD} 25^{+} \mathrm{CD} 103^{+}$Tregs in the periphery than agematched non-sick females and males (Figure 15A \& B, 16A, Table 12). To determine how these populations change over time, we compared $\mathrm{CD} 4^{+} \mathrm{Foxp} 3^{+}$and $\mathrm{CD}^{+} \mathrm{CD} 25^{+} \mathrm{CD} 103^{+}$cell populations in female and male BWF1 mice at different timepoints during disease development, i.e., at 9, 20, 24-28, and 32-36 weeks of age. As reported in specific aim 2, at 9 weeks, females had significantly lower percentages of $\mathrm{CD}^{+}$cells that are Foxp $3^{+}\left(\mathrm{CD}^{+} \mathrm{Foxp}^{+}\right)$than males in LN (21). At 20 weeks of age, 
female and male percentages of $\mathrm{CD}^{+} \mathrm{Foxp}^{+}$cells in $\mathrm{LN}$ were not significantly different, but the percentages still tended to be lower in females than males (Figure 21). By 24-28 weeks, there were no differences in percentages of $\mathrm{CD}^{+} \mathrm{Foxp}^{+}$cells in $\mathrm{LN}$ between females and males (Figure 21). At 32-36 weeks of age, sick females had significantly higher percentages of $\mathrm{CD} 4^{+} \mathrm{Foxp} 3^{+}$cells in the $\mathrm{LN}$ than age-matched non-sick females and males (Figure 21). In the spleen, there were no differences between female and male percentages of $\mathrm{CD}^{+}{ }^{+}$oxp $3^{+}$cells at 9 weeks, 20 weeks, or $24-28$ weeks (data not shown). It was not until 32-36 weeks that differences were seen in the spleen, with sick females having significantly higher percentages of $\mathrm{CD}^{+} \mathrm{Foxp}^{+}$cells (Figure 15A). Percentages of $\mathrm{CD}^{+} \mathrm{CD} 25^{+} \mathrm{CD} 103^{+}$cells in the $\mathrm{LN}$ followed the same pattern as percentages of $\mathrm{CD}^{+}{ }^{+} \mathrm{Foxp} 3^{+}$cells; at 9 weeks, females were significantly lower; there was no difference at 20 weeks but females trended lower; and at 24-28 weeks there was no difference between females and males (Figure 22). Again, at 32-36 weeks, sick females had significantly higher percentages of $\mathrm{CD}^{+} \mathrm{CD} 25^{+} \mathrm{CD} 103^{+}$cells than age-matched non-sick females and males (Figure 22). In spleen, 9 week old BWF1 females had significantly lower $\mathrm{CD} 4^{+} \mathrm{CD} 25^{+} \mathrm{CD} 103^{+}$percentages than males, there was no significant difference at 20 weeks or 24-28 weeks of age, and at 32-36 weeks, sick females had significantly higher percentages of $\mathrm{CD}^{+} \mathrm{CD} 25^{+} \mathrm{CD} 103^{+}$cells than age-matched non-sick females and males (data not shown). In addition, we found no difference in suppressive function of $\mathrm{CD}^{+} \mathrm{CD} 25^{+} \mathrm{CD} 103^{+}$Tregs in vitro between females and males at any age tested (Figure 23). These data suggest that 9 weeks of age may be an important time-point during disease development and the appropriate Treg to effector $\mathrm{T}$ cell balance may be critical (Fig. 24). 


\section{At nine weeks of age, pre-disease female BWF1 mice had no defect in Treg suppressive function in vitro but may be unable to control effector $T$ cell proliferation in vivo.}

We found that 9 weeks of age (pre-disease) may represent an interesting and important time-point during disease development when gender differences in Treg populations may set the scene for gender differences in disease susceptibility later in life. As shown in specific aim 2 and discussed above, both $\mathrm{CD} 4^{+} \mathrm{CD} 25^{+}$and $\mathrm{CD}^{+} \mathrm{CD} 25^{+} \mathrm{CD} 103^{+}$cells from 9-week-old female BWF1 mice were as effective as male cells in suppressing $\mathrm{CD}^{+} \mathrm{CD} 25^{-}$responders (Figure 8, 10D, 23A). To normalize the experimental conditions so that results between females and males were comparable, regulatory function by female and male Tregs in those experiments were tested using male responders and APCs. As mentioned previously, Morel and colleagues found $\mathrm{CD} 4^{+} \mathrm{CD} 25^{-}$responder cells from sick females were resistant to suppression in another mouse model of lupus, which appeared to be due to increased IL- 6 production by DC $(115,116)$. For this reason, we first compared sensitivity of female and male $\mathrm{CD} 4^{+} \mathrm{CD} 25^{-}$ responder T cells to suppression by Tregs in vitro. We co-cultured varying numbers of bead-purified $\mathrm{CD} 4{ }^{+} \mathrm{CD} 25^{+}$cells from 9-week-old BWF1 male mice with a fixed number

of female or male $\mathrm{CD} 4^{+} \mathrm{CD} 25^{-}$responder cells, male irradiated spleen cells as APCs, and anti-CD3. Interestingly, we found that female $\mathrm{CD} 4^{+} \mathrm{CD} 25^{\circ}$ responder cells appeared to be more susceptible to suppression than male cells (Figure 25A). To determine whether sick female DC could render $\mathrm{CD} 4^{+} \mathrm{CD} 25^{-}$responder cells resistant to suppression, we cocultured varying numbers of bead-purified $\mathrm{CD} 4^{+} \mathrm{CD} 25^{+}$cells from males with male 
$\mathrm{CD} 4^{+} \mathrm{CD} 25^{-}$responder cells, female or male irradiated spleen cells as APCs, and antiCD3. We found no significant differences between the ability of 9-week-old female and male APCs to support suppression in vitro (Figure 25B). Finally, to determine whether suppressive function of female Tregs in an environment where all cell components of the assay were either from females or males, we co-cultured varying numbers of beadpurified $\mathrm{CD} 4^{+} \mathrm{CD} 25^{+}$cells from females or males with gender-matched $\mathrm{CD} 4^{+} \mathrm{CD} 25^{-}$ responder cells and irradiated spleen cells as APCs, and anti-CD3. We found no differences in Treg suppressive function in the all female group compared to the all male environment in vitro (Figure 25C). These data together suggest that females do not have a defect in inherent suppressive function or in the ability of their responder $T$ cells to be suppressed, but do have reduced Treg percentages and numbers when compared to males that could influence their susceptibility to disease. However, $\mathrm{CD}^{+}{ }^{+} \mathrm{Foxp} 3^{-}$effector $\mathrm{T}$ cells proliferated more in vivo in 9-week-old females than in males (Figure 12B). These data may suggest that while the female Tregs are functional, the responder $\mathrm{T}$ cells sensitive to suppression and the APC capable of supporting suppression in vitro, there may be some other factor(s) that may interfere with the ability of Tregs to function properly in vivo. And this appears to be true at both the early time-point before disease onset at 9 weeks of age as well as after disease is established by 32-36 weeks of age, and may be indicative of early uncontrolled activation of $\mathrm{T}$ cells. 
Pre-disease CD103-depletion in vivo accelerated and enhanced disease in female and male lupus-prone BWF1 mice.

We found reduced proportions of Tregs in the peripheral lymphoid organs of 9week-old female BWF1 mice compared to males (Figure 9A, 10A, 21, 22), and we propose that this is a critical early timepoint during disease development. Previous studies have shown that depletion of $\mathrm{CD} 25^{+}$cells in female BWF1 with an anti-CD25 monoclonal antibody at 3 days of age resulted in increased dsDNA production and urine protein levels ( $\geq 300 \mathrm{mg} / \mathrm{dL}$ ) by 4.5 months of age (174), suggesting that early depletion of $\mathrm{CD} 25^{+}$cells could accelerate disease in this strain of mice. We were interested in determining whether depleting the $\mathrm{CD} 103^{+}$Treg population had an impact on disease progression in both females and males during the period of development when females had lower percentages of this population. For this experiment, we depleted $\mathrm{CD}_{103}{ }^{+}$cells using a depleting monoclonal antibody. Anti-CD103 antibody or an isotype control antibody was administered to female and male mice twice a week from 8-12 weeks of age and twice a month from 12-20 weeks of age (Figure 24). This treatment regimen almost completely depleted all $\mathrm{CD} 03^{+}$cells during this time-period in the blood (Figure 26). We found that CD103 depletion accelerated disease in both females and males when compared to isotype-treated animals (Figure 27A, 27C). In females, both disease onset and death were accelerated in anti-CD103-treated compared to isotype-treated mice (Figure 27). In fact, $100 \%$ of anti-CD103 treated females in experiment \#1 were dead by 42 weeks of age, whereas the same percent mortality was not seen in isotype antibodytreated females until 53 weeks of age (Figure 27B, 27D). However, the most striking data 
were seen in the males. Although anti-nucleic antibodies can be detected in males fairly early on, we rarely see full-blown disease, and if we do it is after 60 weeks of age. After treatment with anti-CD103 antibody, we saw a dramatic increase in both disease incidence ( $50-70 \%$ by 50 weeks) and mortality ( $30-70 \%$ by 60 weeks; Figure 27$)$. These data indicate that loss of $\mathrm{CD} 103^{+}$Tregs early on can impact disease development and severity and give support to the hypothesis that reduced female Treg numbers and percentages at 9 weeks of age compared to males may set the stage for their increased disease susceptibility later in life.

\section{Summary}

In this study, we found that 32-36-week-old sick female mice have higher percentages of both $\mathrm{CD} 4^{+} \mathrm{Foxp} 3^{+}$and $\mathrm{CD} 4^{+} \mathrm{CD} 25^{+} \mathrm{CD} 103^{+}$cells in the periphery when compared to age-matched non-sick females and males. Sick female Tregs do not show a defect in suppressive function. We found 9-week-old females had lower percentages of $\mathrm{CD}^{+}{ }^{+} \mathrm{Foxp}^{+}$and $\mathrm{CD} 4^{+} \mathrm{CD} 25^{+} \mathrm{CD} 103^{+}$cells in the periphery compared to age-matched males. Nine weeks appears to be an important time period in disease progression. Depletion of $\mathrm{CD}_{103}{ }^{+}$cells in females and males starting at 8 weeks decreased time to disease and increased death in both female and male BWF1 mice. Thus, decreased Treg numbers and percentages in female BWF1 mice early in development may increase their susceptibility to disease. 

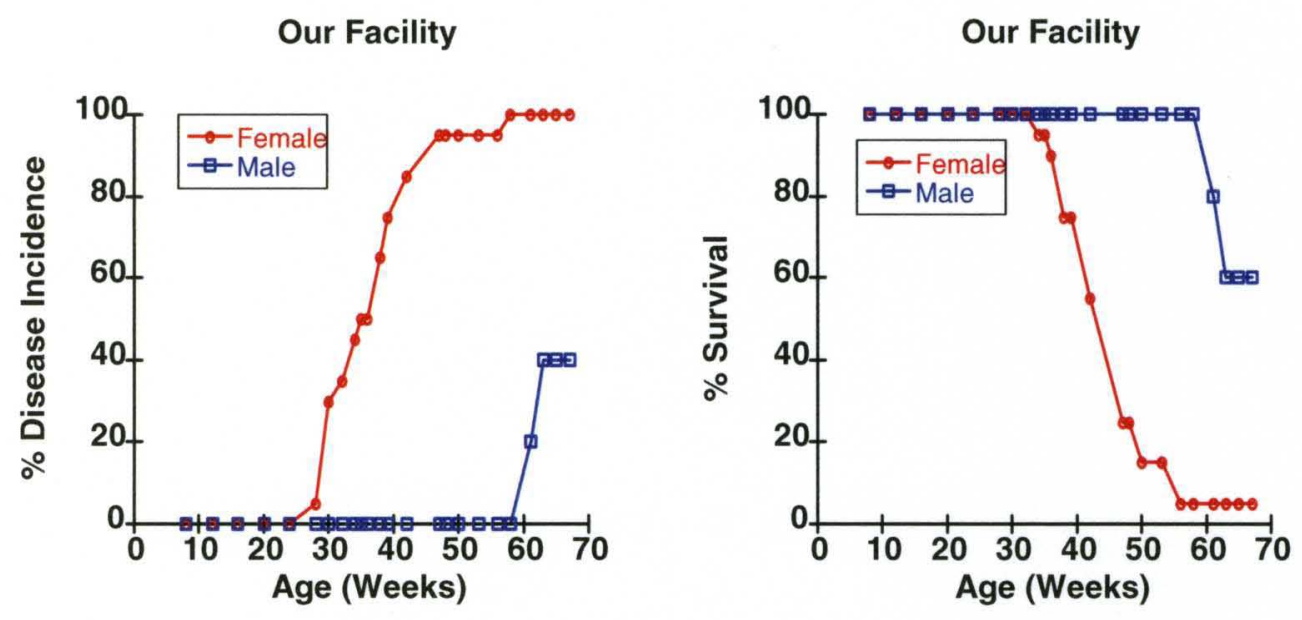

Figure 13. Disease progression in our facility. Urine from female and male BWF1 mice was tested for protein starting at 20 weeks of age. Mice were considered "sick" when the protein in their urine reached a score of 3 ( $\geq 300 \mathrm{mg} / \mathrm{dL})$ for two consecutive weeks. (A) Disease incidence. (B) Survival. (females $n=20$, males $n=5$ ). 

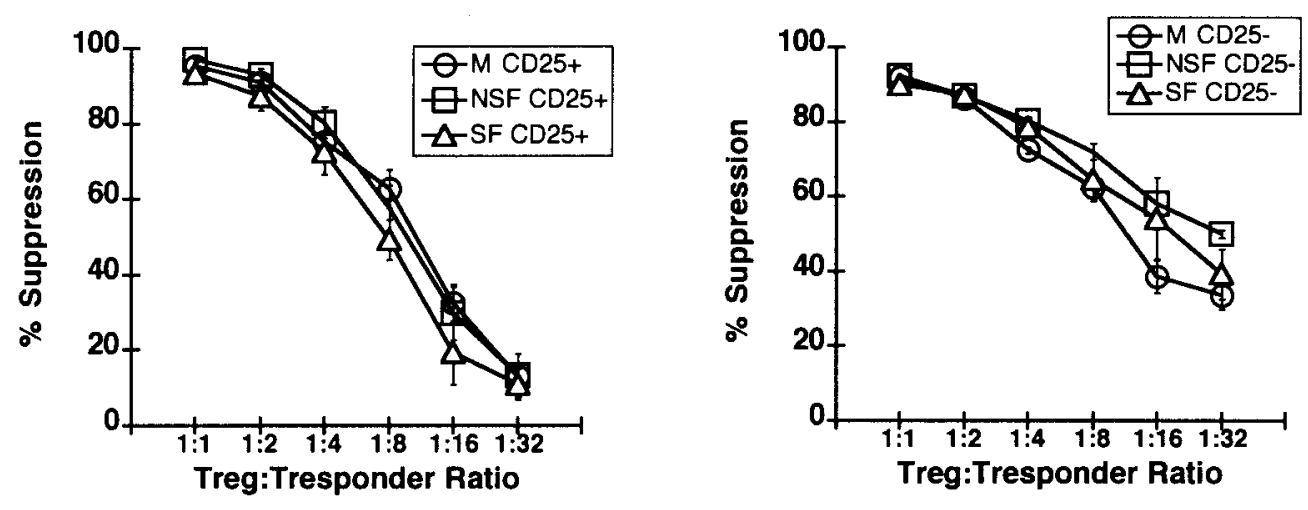

C

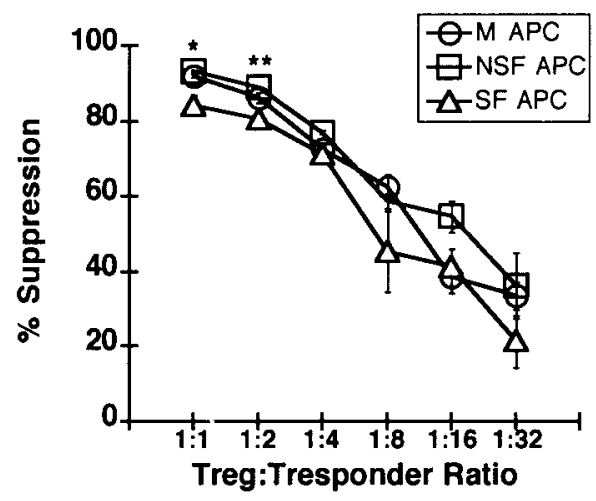

Figure 14. Regulatory function in vitro in 32-36-week-old BWF1 mice. (A) To test for $\mathrm{CD}^{+} \mathrm{CD} 25^{+}$regulatory function, $\mathrm{CD} 4^{+} \mathrm{CD} 25^{+}$cells were purified from $32-36$-week-old sick female, non-sick female, and male BWF1 mice and varying numbers co-cultured with a constant number of male $\mathrm{CD} 4^{+} \mathrm{CD} 25^{-}$responder cells, male APC, and soluble antiCD3 antibody. \% suppression of positive control (responder cells without Tregs) was calculated and the mean \pm SEM presented. (B) To test for $\mathrm{CD} 4^{+} \mathrm{CD} 25^{-}$responder cell sensitivity to suppression, $\mathrm{CD} 4^{+} \mathrm{CD} 25^{+}$cells were purified from male 32-36-week-old 
BWF1 mice and varying numbers co-cultured with a constant number of 32-36-week-old sick female, non-sick female, and male $\mathrm{CD} 4^{+} \mathrm{CD} 25^{-}$responder cells, male APCs, and soluble anti-CD3 antibody. \% suppression of positive control (responder cells without Tregs) was calculated and the mean \pm SEM presented. (C) To test for the ability of APCs to support suppression, $\mathrm{CD} 4^{+} \mathrm{CD} 25^{+}$cells were purified from male 32-36-week-old BWF1 mice and varying numbers co cultured with a constant number of male $\mathrm{CD} 4^{+} \mathrm{CD} 25^{-}$responder cells, sick female, non-sick female, or male APCs, and soluble anti-CD3 antibody. \% suppression of positive control (responder cells without Tregs) was calculated and the mean \pm SEM presented. A representative experiment of 3 performed is shown. Statistical differences were analyzed using a student's $t$ test or ANOVA and the Tukey-Kramer multiple comparisons test. ${ }^{*} \mathrm{p}<0.05,{ }^{* *} \mathrm{p}<0.005$, and ${ }^{* * *} \mathrm{p}<0.0005$. 
A

LN

Spleen
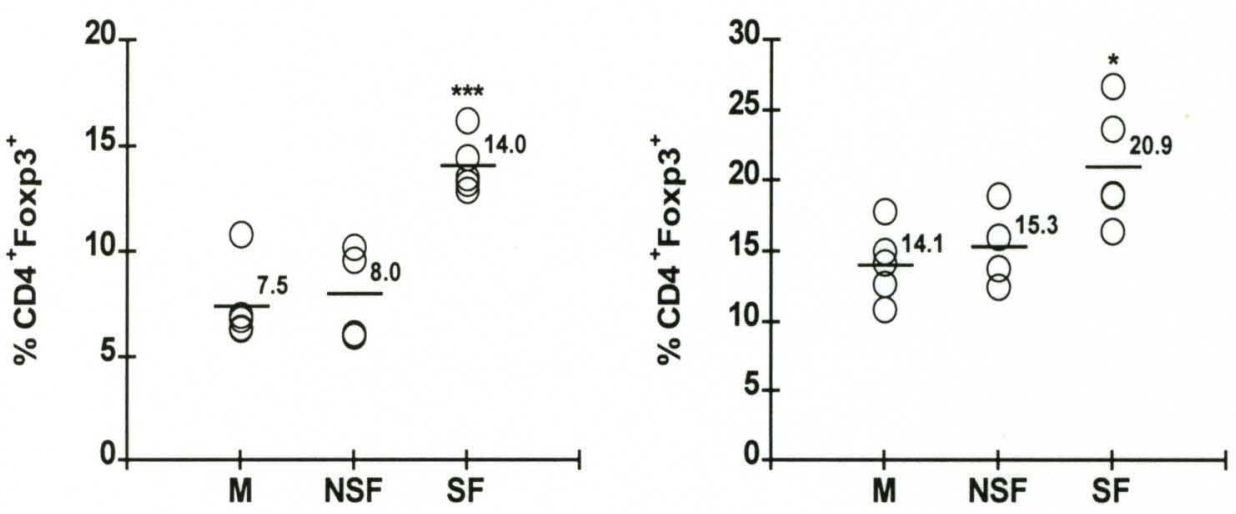

B

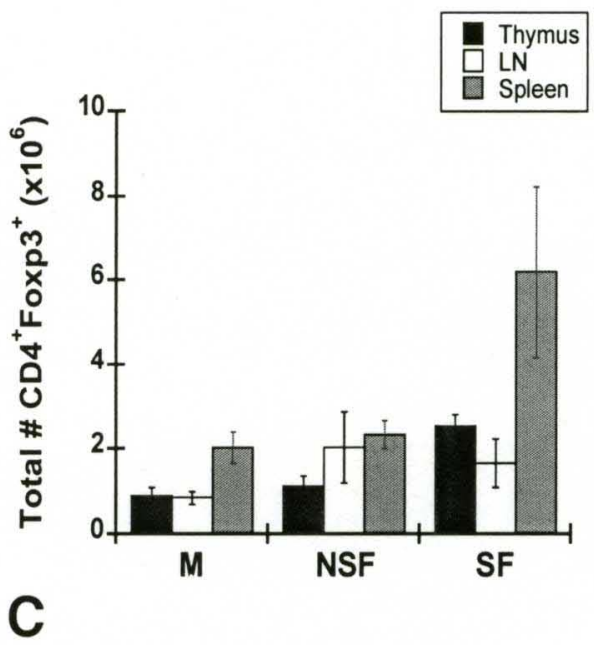

LN

Spleen
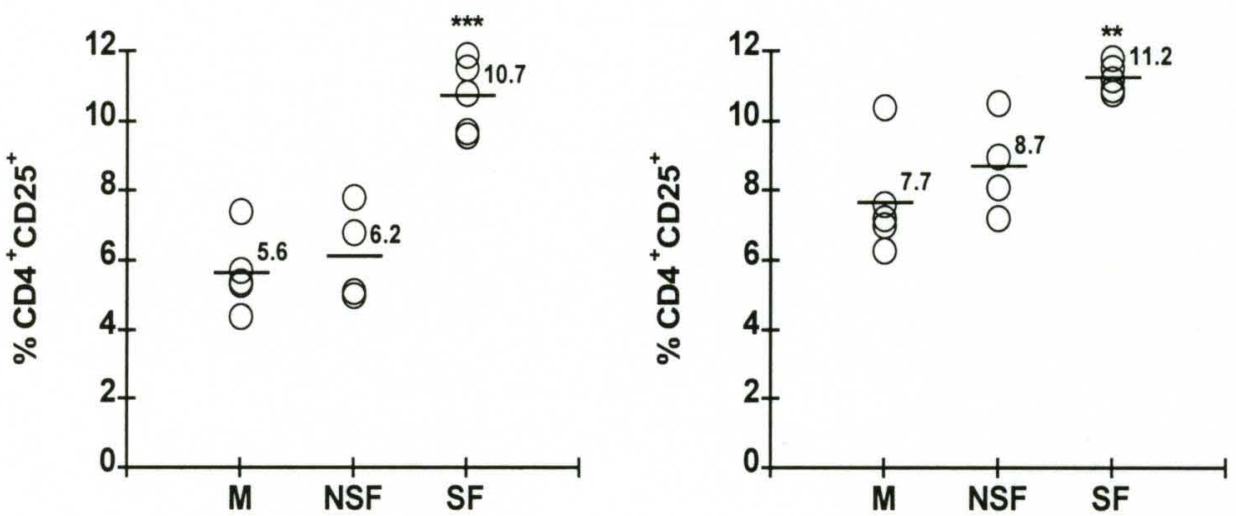


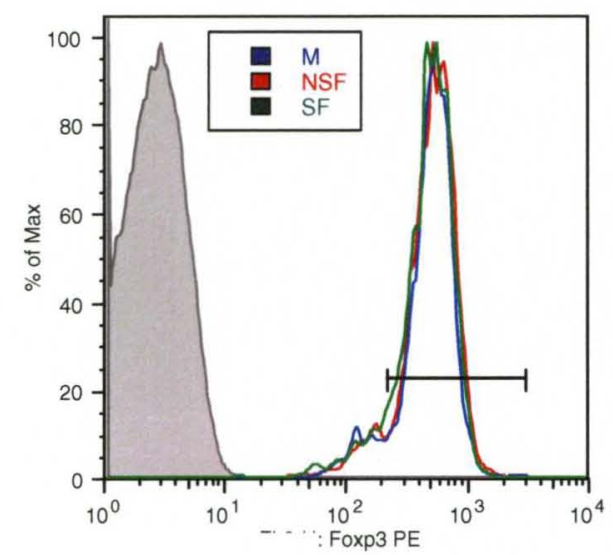

Figure 15. Percentages and numbers of $\mathrm{CD}^{+} \mathrm{Foxp}^{+}$cells in 32-36-week-old BWF1 mice. Cells from lymph nodes (LN), spleen, and thymus of 32-36-week-old sick female, non-sick female, and male BWF1 mice were labeled with anti-CD4, anti-CD25, and antiFoxp3 antibodies and analyzed by $\mathrm{FACS}^{\circledR}$. (A) Labeled $\mathrm{CD}^{+}$cells were gated and analyzed for the percentages of cells expressing Foxp3 in LN and spleen. (B) The total numbers of $\mathrm{CD}^{+}{ }^{+} \mathrm{Foxp}^{+}$cells are shown in $\mathrm{LN}$ and spleen. (C) Labeled $\mathrm{CD} 4^{+}$cells were gated and analyzed for the percentages of cells expressing CD25 in LN and spleen. (D) A sample histogram showing Foxp3 expression on $\mathrm{CD} 4^{+} \mathrm{CD} 25^{+}$cells in $\mathrm{LN}$ is shown. (A,C) A representative experiment of 4-6 performed is shown. Each symbol represents an individual animal. Statistical differences were analyzed using a student's t test or ANOVA and the Tukey-Kramer multiple comparisons test. $* \mathrm{p}<0.05$, * ${ }^{*} \mathrm{p}<0.005$, and $* * * \mathrm{p}<0.0005$. 
A

LN

Spleen
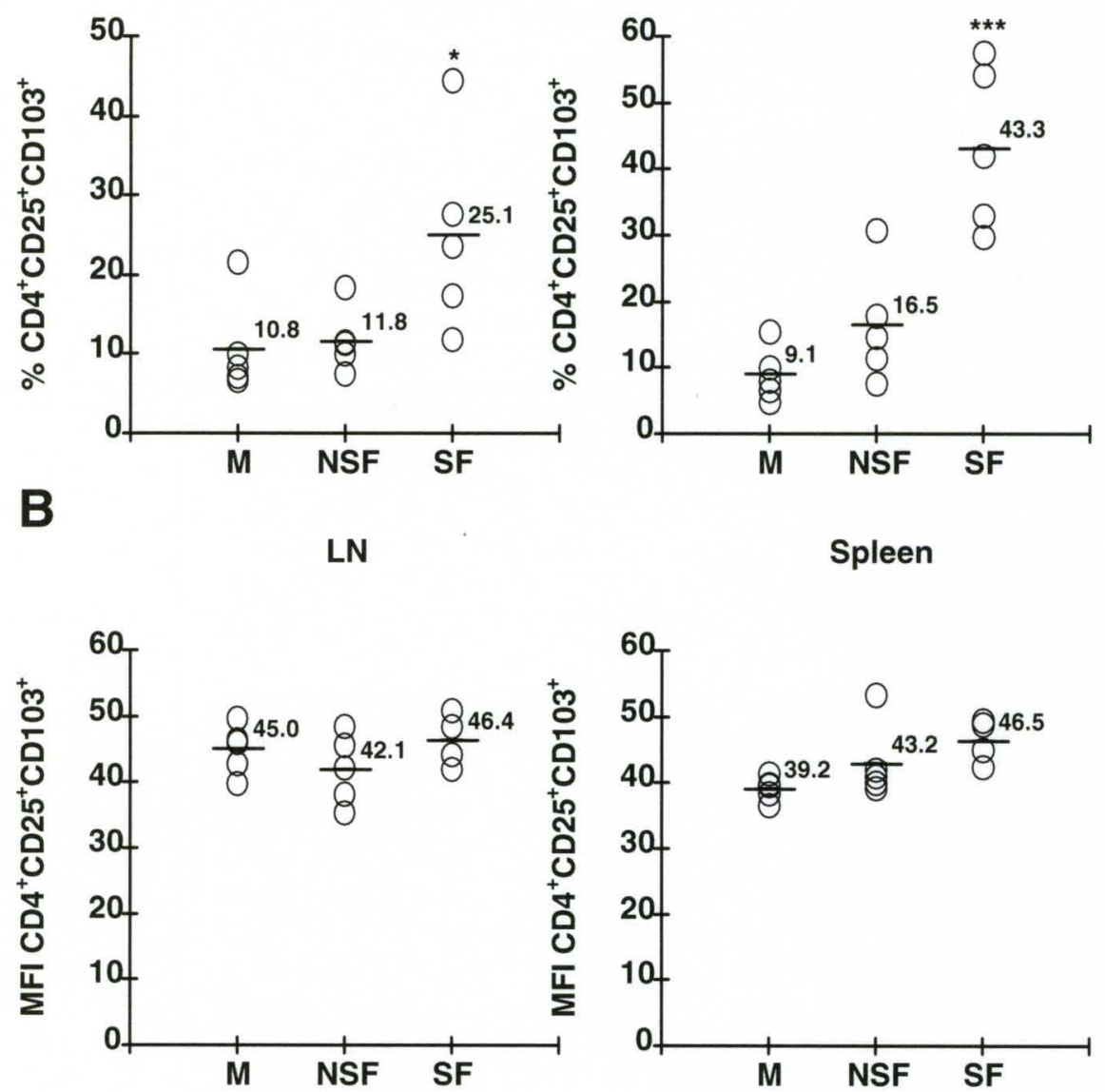

C

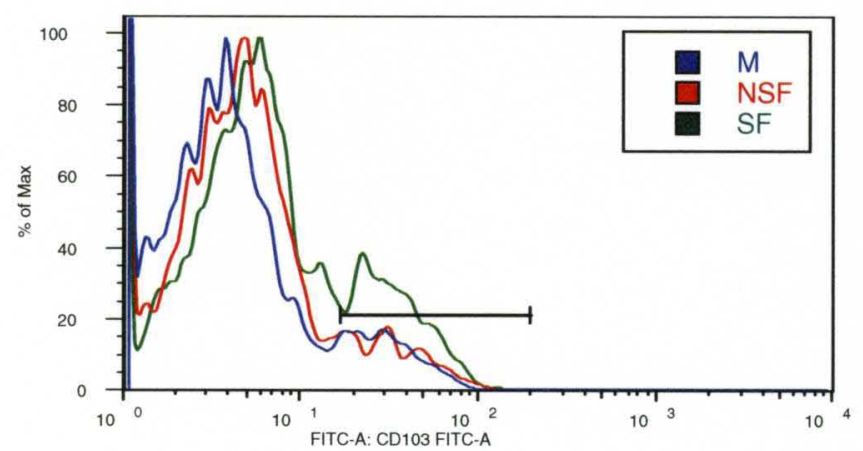




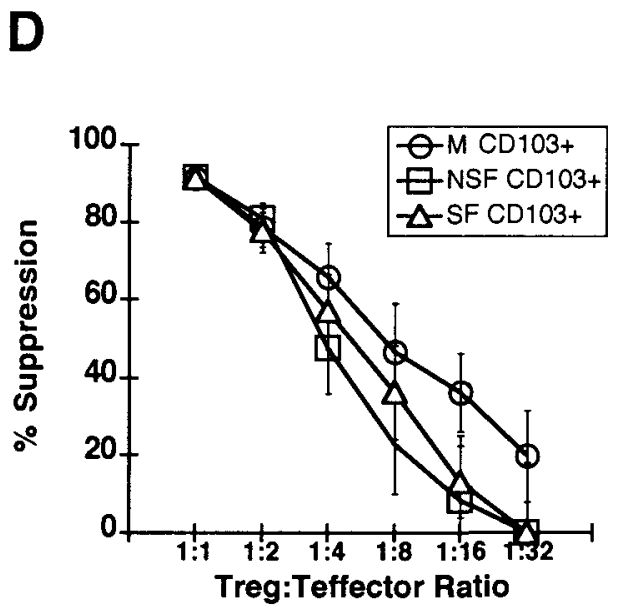

Figure 16. Percentages and in vitro suppressive function of $\mathrm{CD} 4^{+} \mathrm{CD} 25^{+} \mathrm{CD} 103^{+}$cells in 32-36-week-old BWF1 mice. Cells from lymph nodes (LN) and spleen of 32-36-weekold sick female, non-sick female, and male BWF1 mice were labeled with anti-CD4, antiCD25, and anti-CD103 antibodies and analyzed by FACS ${ }^{\circledast}$. (A) Labeled CD4 ${ }^{+} \mathrm{CD} 25^{+}$ cells were gated and analyzed for the percentages of cells expressing CD103 in LN and spleen. (B) Labeled $\mathrm{CD} 4^{+} \mathrm{CD} 25^{+}$cells were gated and analyzed for the per cell expression of CD103 in LN and spleen. (C) A sample histogram showing CD103 expression on $\mathrm{CD} 4^{+} \mathrm{CD} 25^{+}$cells in $\mathrm{LN}$ is shown. (D) $\mathrm{CD} 4^{+} \mathrm{CD} 25^{+} \mathrm{CD} 103^{+}$cells were purified from $32-$ 36-week-old sick female, non-sick female, and male BWF1 mice and varying numbers co-cultured with a constant number of male $\mathrm{CD} 4^{+} \mathrm{CD} 25^{-}$responder cells, male APC, and soluble anti-CD3 antibody. \% suppression of positive control (responder cells alone) was calculated and the mean \pm SEM presented. $(A, B)$ A representative experiment of 3-7 performed is shown. Each symbol represents an individual animal. Statistical differences were analyzed using a student's $t$ test or ANOVA and the Tukey-Kramer multiple comparisons test. ${ }^{*} \mathrm{p}<0.05,{ }^{* *} \mathrm{p}<0.005$, and ${ }^{* * *} \mathrm{p}<0.0005$. 
A

Thymus

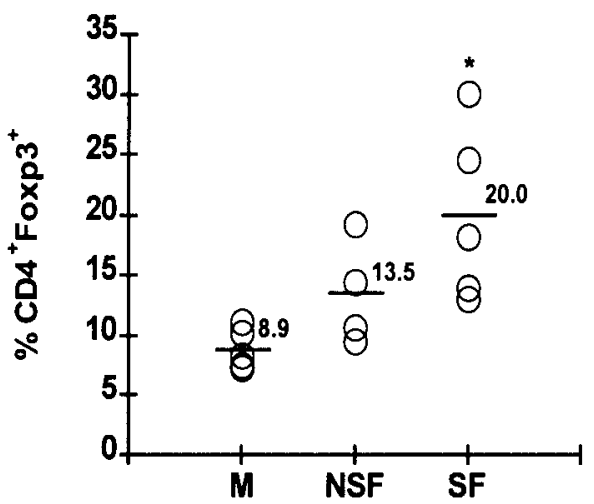

B

Thymus

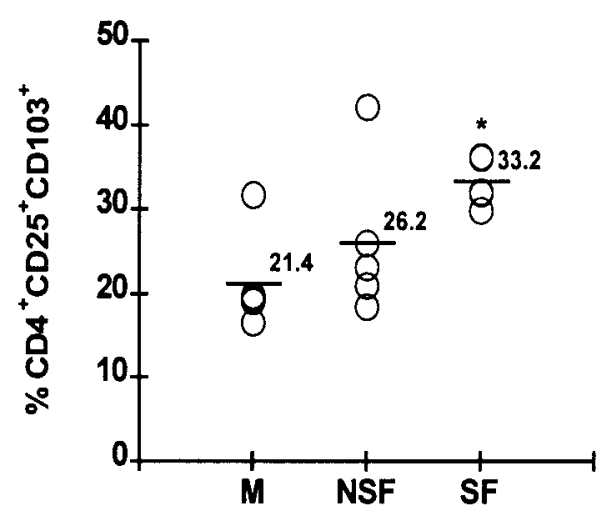

Figure 17. Percentages of $\mathrm{CD} 4^{+} \mathrm{Foxp} 3^{+}$and $\mathrm{CD} 4^{+} \mathrm{CD} 25^{+} \mathrm{CD} 103^{+}$cells in thymus of $32-$ 36-week-old BWF1 mice. Cells from the thymus of 32-36-week-old sick female, nonsick female, and male BWF1 mice were labeled with anti-CD4, anti-CD25, anti-CD103, and anti-Foxp 3 antibodies and analyzed by FACS ${ }^{\circledast}$. Labeled cells were gated and analyzed for (A) percentages of $\mathrm{CD}^{+}$cells expressing Foxp3 and (B) percentages of $\mathrm{CD} 4^{+} \mathrm{CD} 25^{+}$cells expressing CD103. A representative experiment of 3-7 performed is shown. Each symbol represents an individual animal. Statistical differences were analyzed using a student's $t$ test or ANOVA and the Tukey-Kramer multiple comparisons test. ${ }^{*} \mathrm{p}<0.05,{ }^{* *} \mathrm{p}<0.005$, and ${ }^{* * *} \mathrm{p}<0.0005$. 
A

LN

Spleen
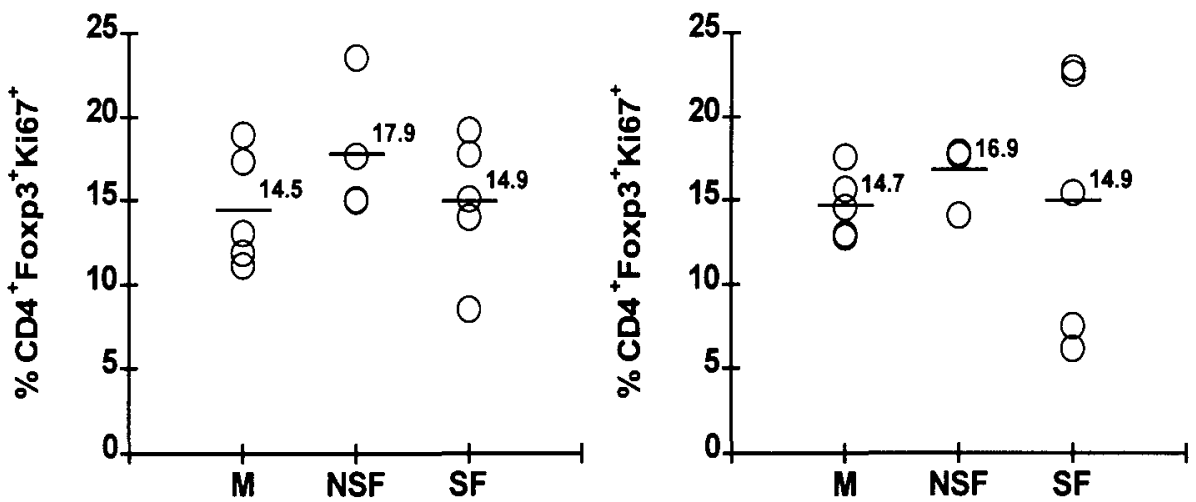

B

LN

Spleen
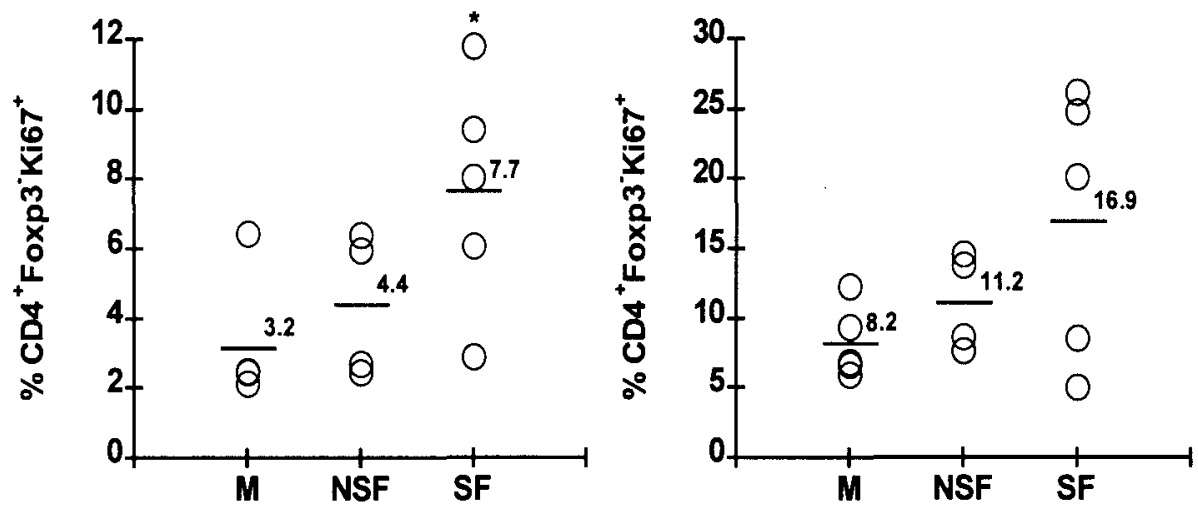
C

LN

Spleen
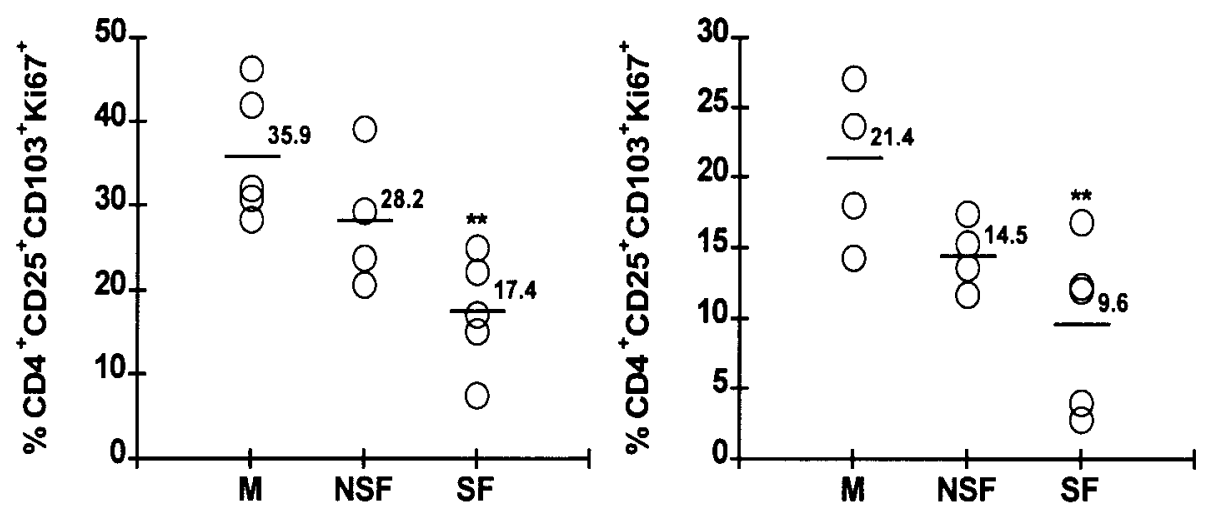

D
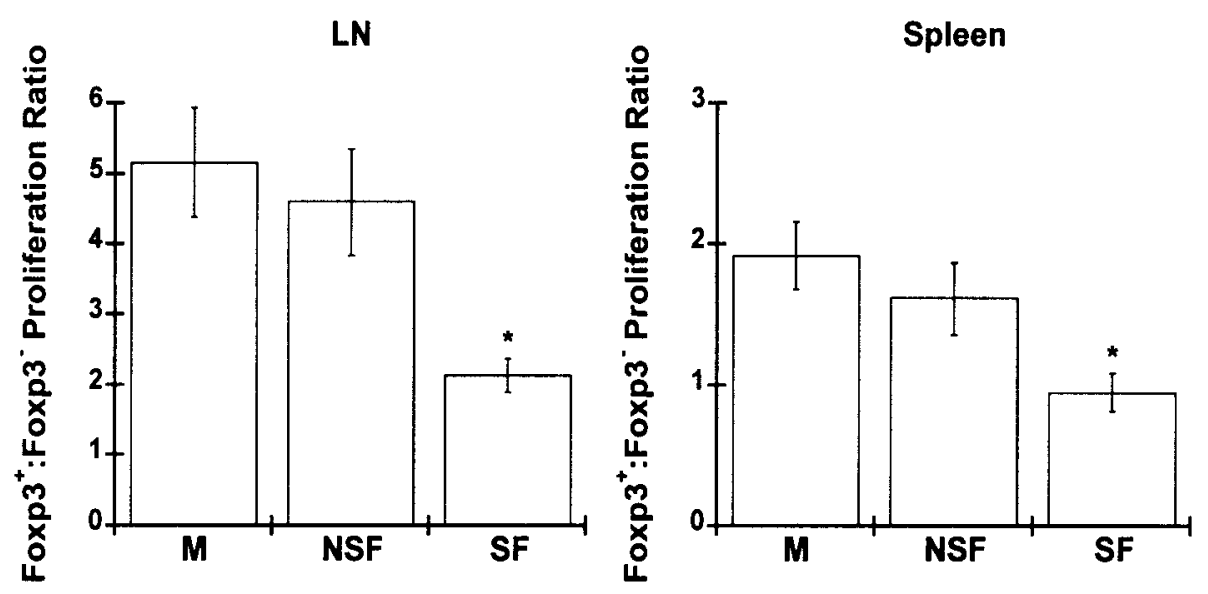

Figure 18. Percentages of proliferating $\mathrm{CD}^{+} \mathrm{Foxp}^{+}, \mathrm{CD}^{+} \mathrm{Foxp}^{-}$, and $\mathrm{CD}^{+} \mathrm{CD} 25^{+} \mathrm{CD} 103^{+}$cells in the periphery of 32-36-week-old sick female, non-sick female, and male BWF1 mice. Cells from LN and spleen of 32-36-week-old sick female, non-sick female, and male BWF1 mice were labeled with anti-CD4, andti-CD25, antiCD103, anti-Foxp3, and anti-Ki67 antibodies and analyzed by FACS ${ }^{\circledR}$. (A) Labeled $\mathrm{CD}^{+}{ }^{+}$Foxp $3^{+}$cells were gated and analyzed for the percentages of cells expressing $\mathrm{Ki} 67$ in $\mathrm{LN}$ and spleen. (B) Labeled $\mathrm{CD} 4^{+}$Foxp3- cells were gated and analyzed for the percentages of cells expressing $\mathrm{Ki} 67$ in $\mathrm{LN}$ and spleen. (C) Labeled $\mathrm{CD} 4^{+} \mathrm{CD} 25^{+} \mathrm{CD} 103^{+}$ 
cells were gated and analyzed for the percentages of cells expressing Ki67 in LN and spleen. (D) Proliferation ratios were calculated by dividing the percentage of proliferating $\left(\mathrm{Ki} 67^{+}\right) \mathrm{CD}^{+} \mathrm{Foxp}^{+}$cells by the percentage of proliferating $\mathrm{CD} 4^{+} \mathrm{Foxp} 3^{-}$cells from $\mathrm{LN}$ and spleen. A representative experiment of 3 performed is shown. (A-C) Each symbol represents an individual animal. Statistical differences were analyzed using a student's $\mathbf{t}$ test or ANOVA and the Tukey-Kramer multiple comparisons test. ${ }^{*} \mathrm{p}<0.05,{ }^{* *} \mathrm{p}<0.005$, and ${ }^{* * *} \mathrm{p}<0.0005$. 
A

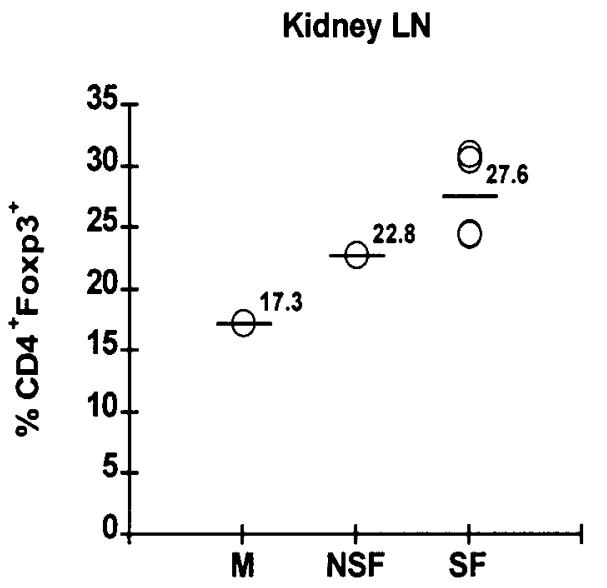

B

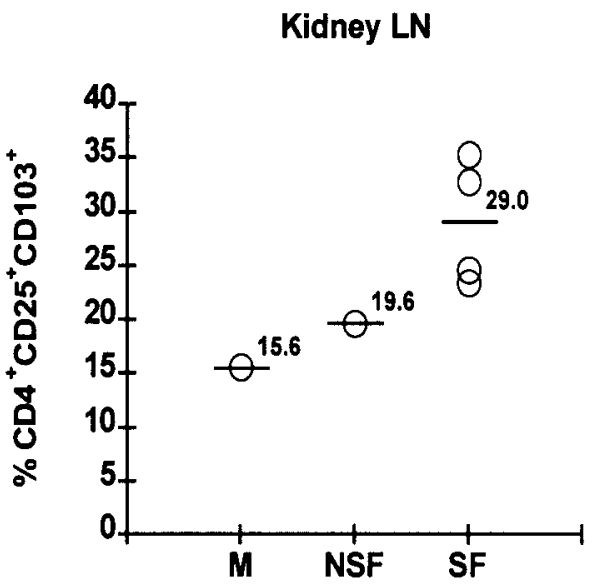

Figure 19. Regulatory T cell percentages in kidney draining LN from 32-36-week-old BWF1 mice. Cells from kidney draining LN of 32-36-week-old sick female, non-sick female, and male BWF1 mice were labeled with anti-CD4, anti-CD25, anti-CD103, and anti-Foxp3 antibodies and analyzed by FACS ${ }^{\circledast}$. (A) Labeled $\mathrm{CD} 4^{+}$cells were gated and analyzed for the percentages of cells expressing Foxp3 and (B) Labeled CD4 $4^{+} \mathrm{CD} 25^{+}$ cells were gated and analyzed for the percentages of cells expressing CD103. A representative experiment of 2 performed is shown. Each symbol represents an individual animal. Statistical differences were analyzed using a student's $t$ test or ANOVA and the Tukey-Kramer multiple comparisons test. ${ }^{*} \mathrm{p}<0.05,{ }^{* *} \mathrm{p}<0.005$, and ${ }^{* * *} \mathrm{p}<0.0005$. 
A

LN

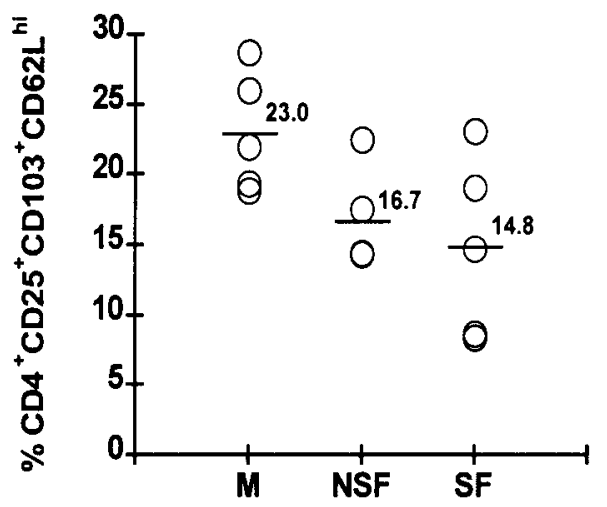

B

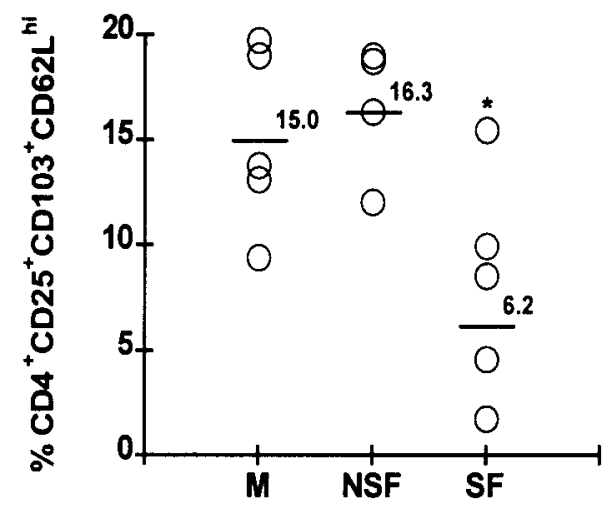

Figure 20. Percentages of $\mathrm{CD} 4^{+} \mathrm{CD} 25^{+} \mathrm{CD} 103^{+} \mathrm{CD} 62 \mathrm{~L}^{\text {hi }}$ cells in 32-36-week-old BWF1 mice. Cells from lymph nodes (LN) and spleen of 32-36-week-old sick female, non-sick female, and male BWF1 mice were labeled with anti-CD4, anti-CD25, anti-CD103, and anti-CD62L antibodies and analyzed by $\mathrm{FACS}^{\oplus}$. Labeled $\mathrm{CD}^{+} \mathrm{CD} 25^{+} \mathrm{CD}_{103^{+}}$cells were gated and analyzed for the percentages of cells expressing CD62L ${ }^{\mathrm{hi}}$ in (A) LN and (B) spleen. A representative experiment of 4 is shown. Each symbol represents an individual animal. Statistical differences were analyzed using a student's $t$ test or ANOVA and the Tukey-Kramer multiple comparisons test. ${ }^{*} \mathrm{p}<0.05,{ }^{* *} \mathrm{p}<0.005$, and ${ }^{* * *} \mathrm{p}<0.0005$. 
9wks

20 Weeks
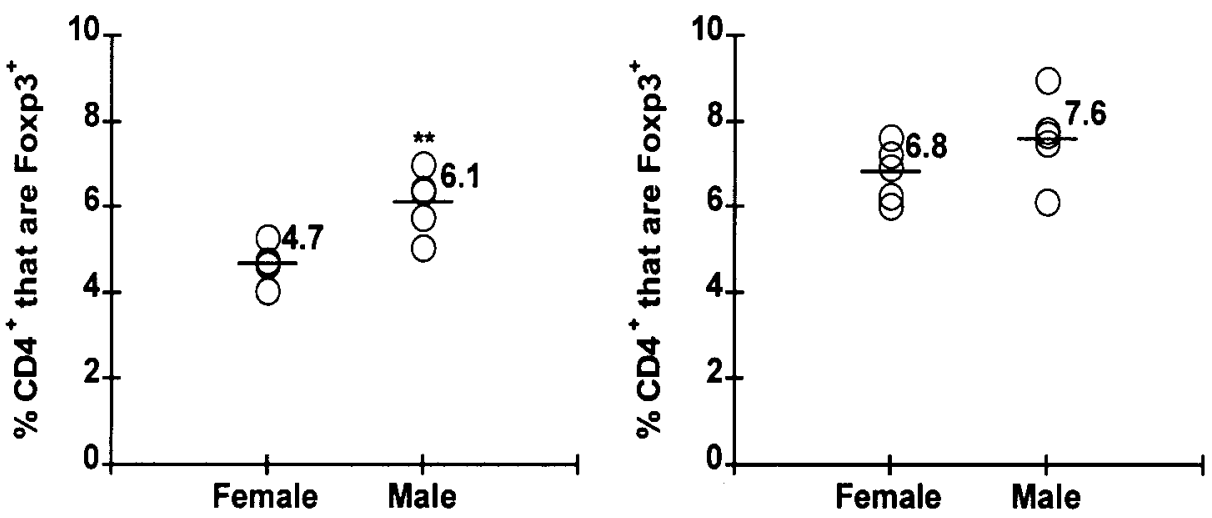

24-28 Weeks
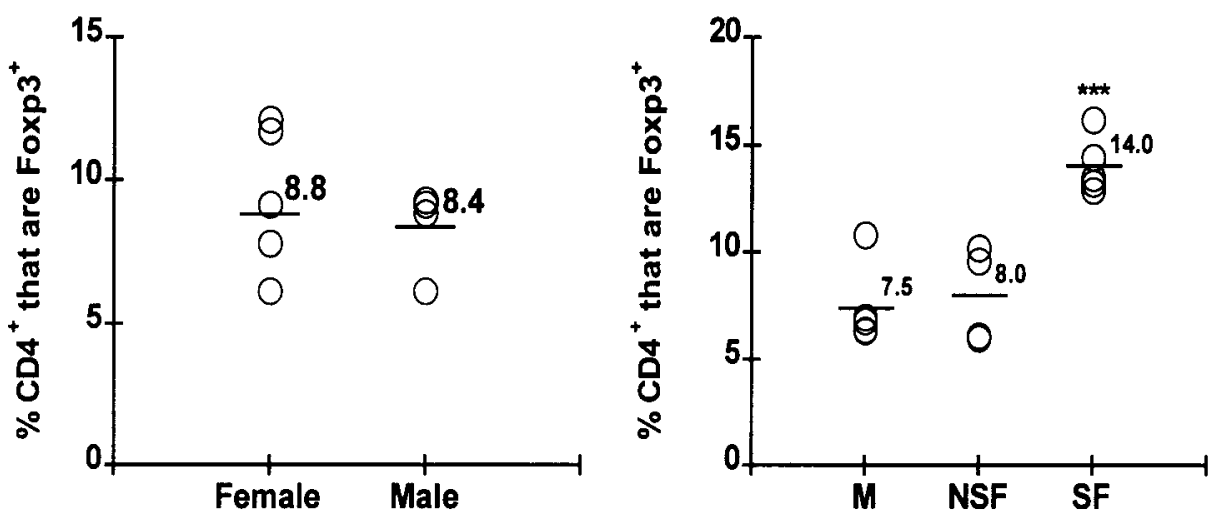

Figure 21. Percentages of CD $4^{+}$Foxp $3^{+}$cells in BWF1 mice. Cells from lymph nodes (LN) of female and male 9-week-old, 20-week-old, 24-28-week-old, and sick female, non-sick female, and male 32-36-week-old mice were labeled with anti-CD4 and antiFoxp3 antibodies and analyzed by $\mathrm{FACS}^{\circledR}$. Labeled $\mathrm{CD} 4^{+}$cells were gated and analyzed for the percentages of cells expressing Foxp3. A representative experiment is shown. Each symbol represents an individual animal. Statistical differences were analyzed using a student's $\mathrm{t}$ test or ANOVA and the Tukey-Kramer multiple comparisons test. ${ }^{*} \mathrm{p}<0.05$, ${ }^{* *} \mathrm{p}<0.005$, and $* * * \mathrm{p}<0.0005$. 
9wks

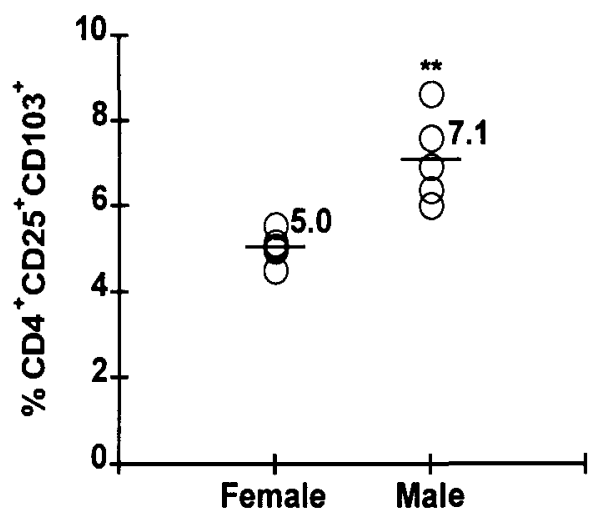

24-28 Weeks

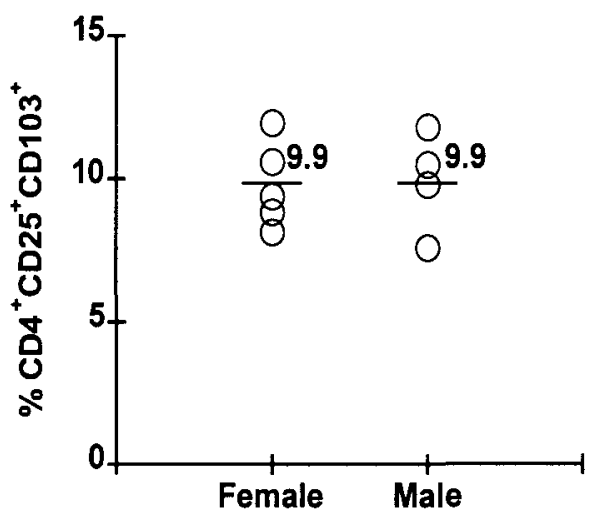

20 Weeks

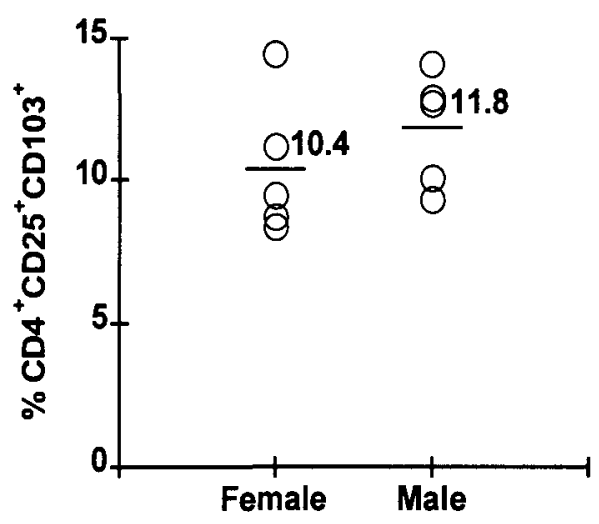

32-36wks

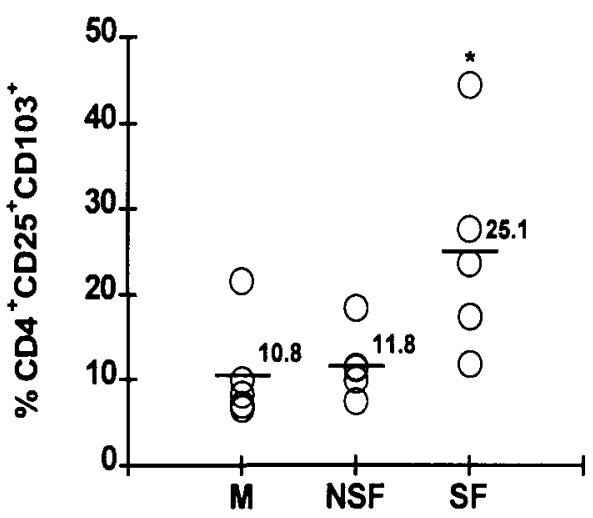

Figure 22. Percentages of $\mathrm{CD}^{+} \mathrm{CD} 25^{+} \mathrm{CD} 103^{+}$cells in BWF1 mice. Cells from lymph nodes (LN) of female and male 9-week-old, 20-week-old, 24-28-week-old, and sick female, non-sick female, and male 32-36-week-old mice were labeled with anti-CD4, anti-CD25, and anti-CD103 antibodies and analyzed by FACS ${ }^{\circledast}$. Labeled $\mathrm{CD} 4^{+} \mathrm{CD} 25^{+}$ cells were gated and analyzed for the percentages of cells expressing CD103. A representative experiment is shown. Each symbol represents an individual animal. Statistical differences were analyzed using a student's t test or ANOVA and the TukeyKramer multiple comparisons test. ${ }^{*} \mathrm{p}<0.05,{ }^{* *} \mathrm{p}<0.005$, and ${ }^{* * *} \mathrm{p}<0.0005$. 
A
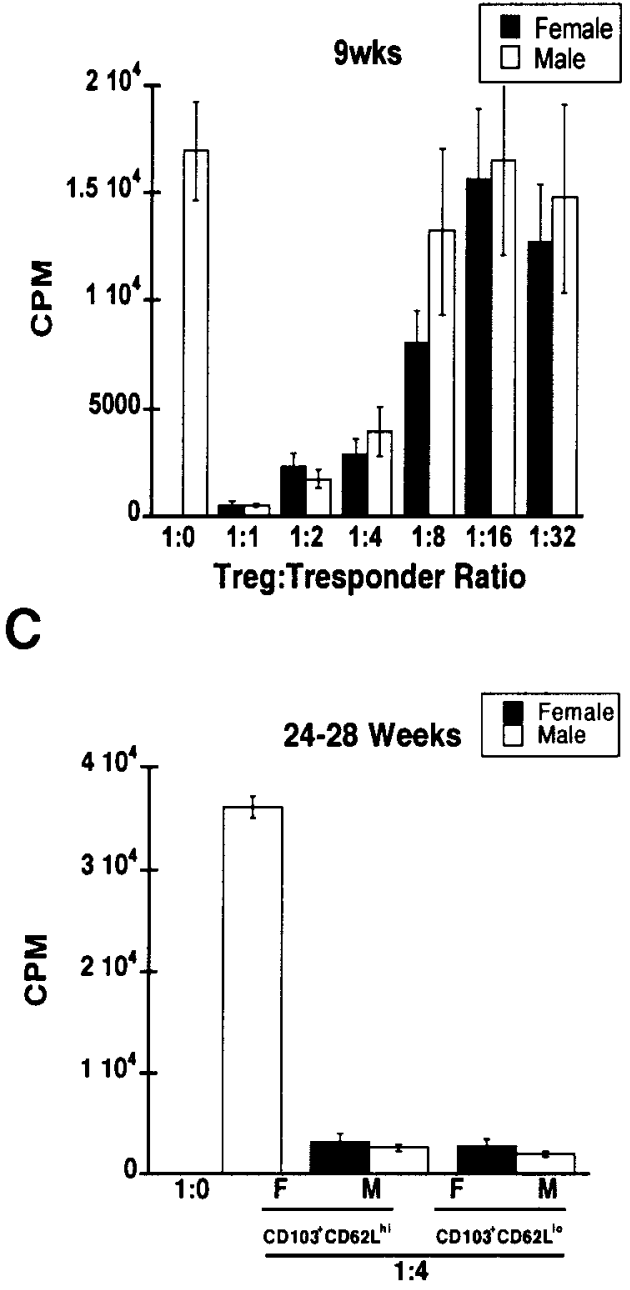

B

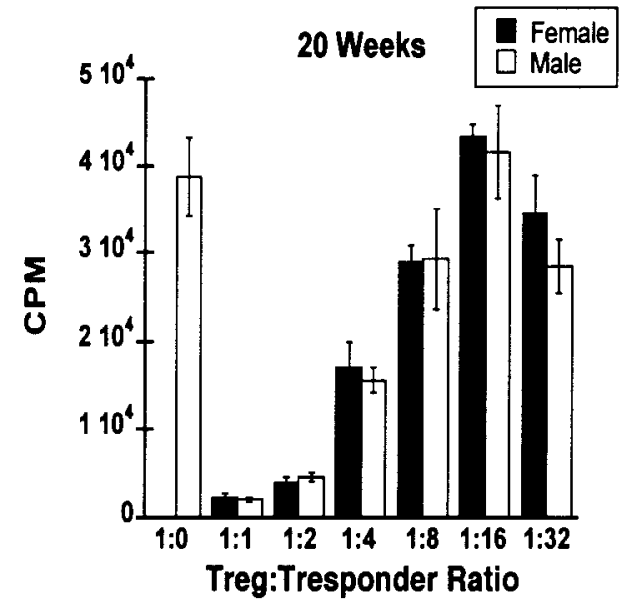

D

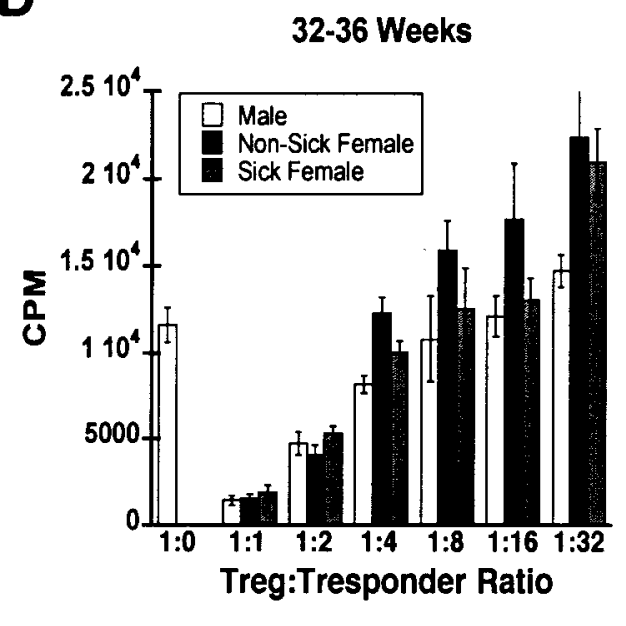

Figure 23. In vitro suppressive function of $\mathrm{CD}_{103^{+}}$Tregs from BWF1 mice. To test for regulatory function $\mathrm{CD} 4^{+} \mathrm{CD} 25^{+} \mathrm{CD} 103^{+}$cells were purified from (A) 9-week-old, (B) 20week-old, (C) 24-28-week-old, and (D) 32-36-week-old sick female, non-sick female, and male BWF1 mice and varying numbers co-cultured with a constant number male $\mathrm{CD}^{+} \mathrm{CD} 25^{-}$responder cells, male $\mathrm{APC}$, and soluble anti-CD3 antibody. (A,D) A representative experiment of 3 performed is shown. (B) A representative experiment of 2 performed is shown. (C) 24-28-week-old $\mathrm{CD} 4^{+} \mathrm{CD} 25^{+} \mathrm{CD} 103^{+}$cells were further sorted into $\mathrm{CD} 62 \mathrm{~L}^{\mathrm{hi}}$ and $\mathrm{CD} 62 \mathrm{~L}^{\mathrm{lo}}$ populations. $\mathrm{CPM}$ is presented as mean $\pm \mathrm{SEM}$. Statistical 
differences were analyzed using a student's $t$ test or ANOVA and the Tukey-Kramer multiple comparisons test. ${ }^{*} \mathrm{p}<0.05,{ }^{* *} \mathrm{p}<0.005$, and ${ }^{* * *} \mathrm{p}<0.0005$. 


\section{Disease Time-line}

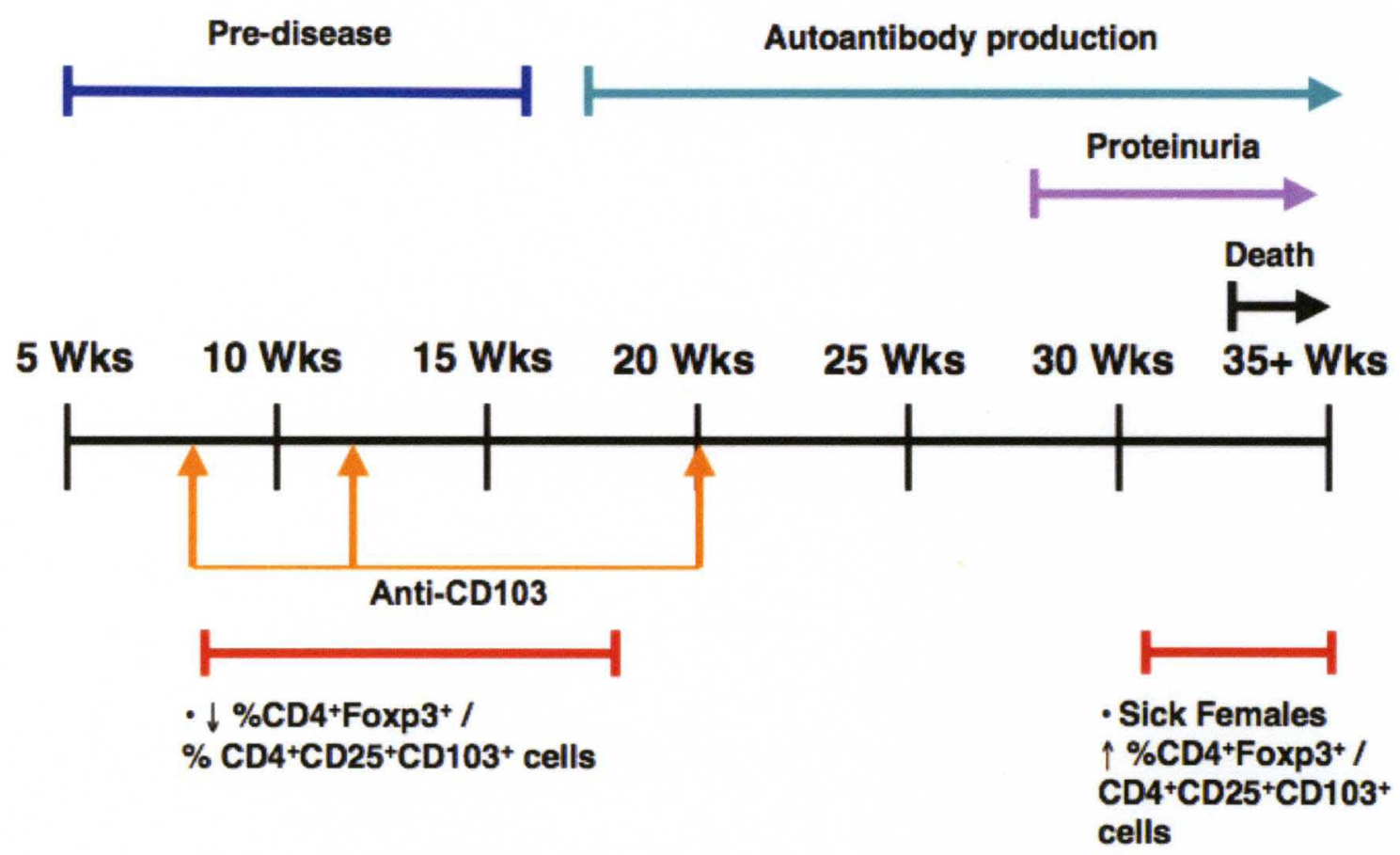

Figure 24. Disease timeline and anti-CD103 monoclonal antibody treatment in BWF1 mice. A schematic of lupus symptom development is shown, including initiation of autoantibody production and detection of proteinuria. The anti-CD103 monoclonal antibody treatment protocol is also shown (results are shown in Figure 26). 
B
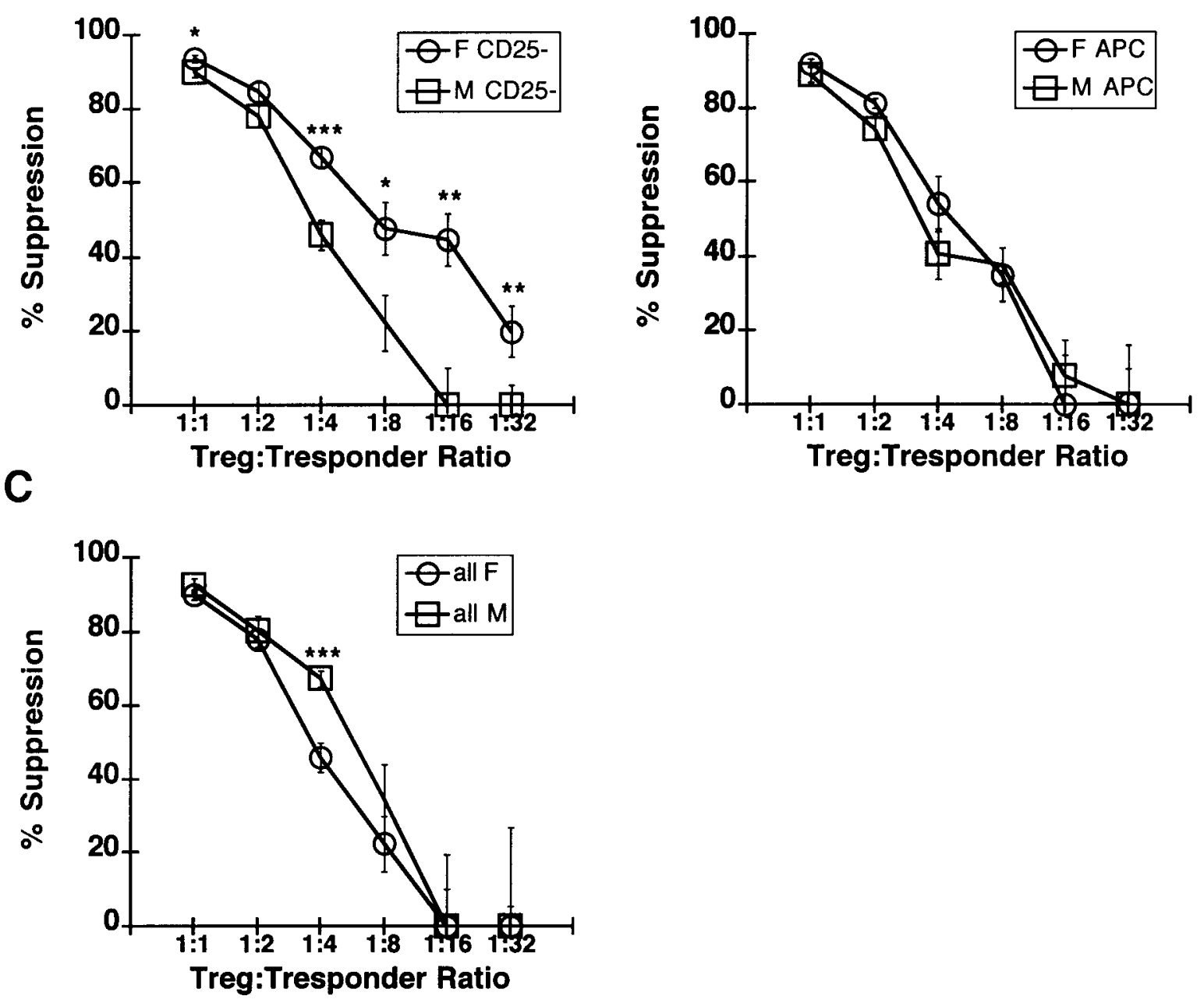

Figure 25. Regulatory function in vitro of cells from 9-week-old BWF1 mice. (A) To test for $\mathrm{CD}^{+} \mathrm{CD} 25^{-}$responder cell sensitivity to suppression, $\mathrm{CD} 4^{+} \mathrm{CD} 25^{+}$cells were purified from male 9-week-old BWF1 mice and varying numbers co-cultured with a constant number of 9-week-old female or male $\mathrm{CD} 4^{+} \mathrm{CD} 25^{-}$responder cells, male APCs, and soluble anti-CD3 antibody. \% suppression of positive control (responder cells alone) was calculated and the mean \pm SEM presented. (B) To test for the ability of APCs to support suppression, $\mathrm{CD}^{+} \mathrm{CD} 25^{+}$cells were purified from male 9-week-old BWF1 mice and 
varying numbers co-cultured with a constant number of male $\mathrm{CD} 4^{+} \mathrm{CD} 25^{-}$responder cells, female or male APCs, and soluble anti-CD3 antibody. \% suppression of positive control (responder cells alone) was calculated and the mean \pm SEM presented. (C) To test for suppressive function with all female or all male cells, $\mathrm{CD} 4^{+} \mathrm{CD} 25^{+}$cells were purified from female or male 9-week-old BWF1 mice and varying numbers co-cultured with a constant number of gender-matched $\mathrm{CD}^{+} \mathrm{CD} 25^{-}$responder cells, gender-matched APCs, and soluble anti-CD3 antibody. A representative experiment of 3 performed is shown. Statistical differences were analyzed using a student's $t$ test or ANOVA and the TukeyKramer multiple comparisons test. ${ }^{*} \mathrm{p}<0.05,{ }^{* *} \mathrm{p}<0.005$, and ${ }^{* * *} \mathrm{p}<0.0005$. 

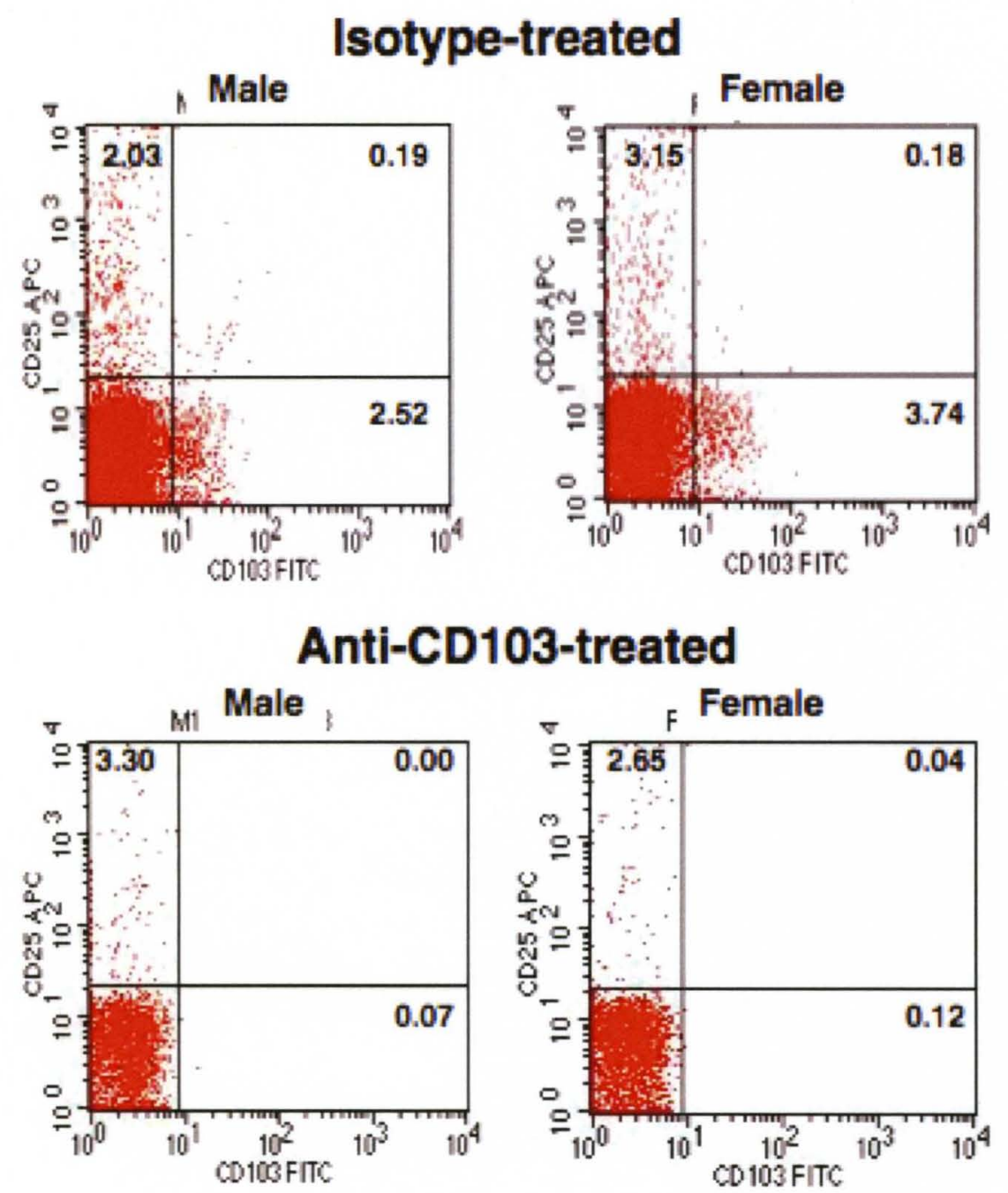

Figure 26. In vivo CD103-depletion in pre-diseased BWF1 mice. 8wk old female and male BWF1 mice were treated twice weekly with $0.5 \mathrm{mg}$ anti-CD103 for 4 weeks, then twice monthly until 20 wks of age. Mice were considered sick when they had a proteinuria score of 3 for two consecutive weeks. Sample FACS figure comparing CD103 expression in the blood of anti-CD103-treated versus isotype-treated mice. 
A
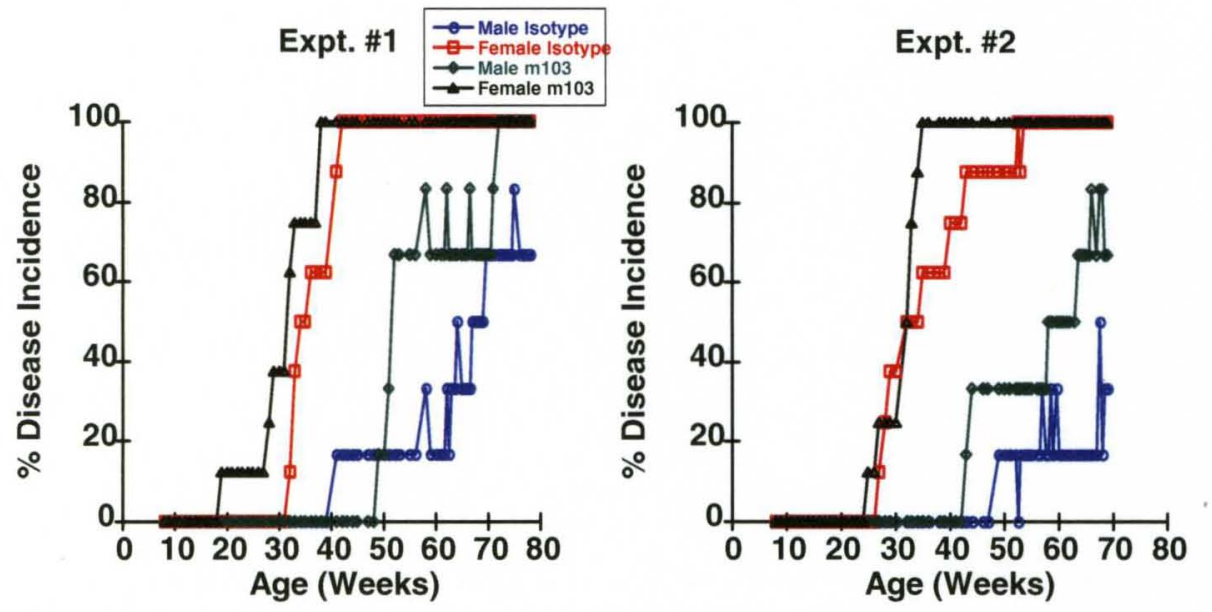

B

Expt. \#1

Expt. \#2
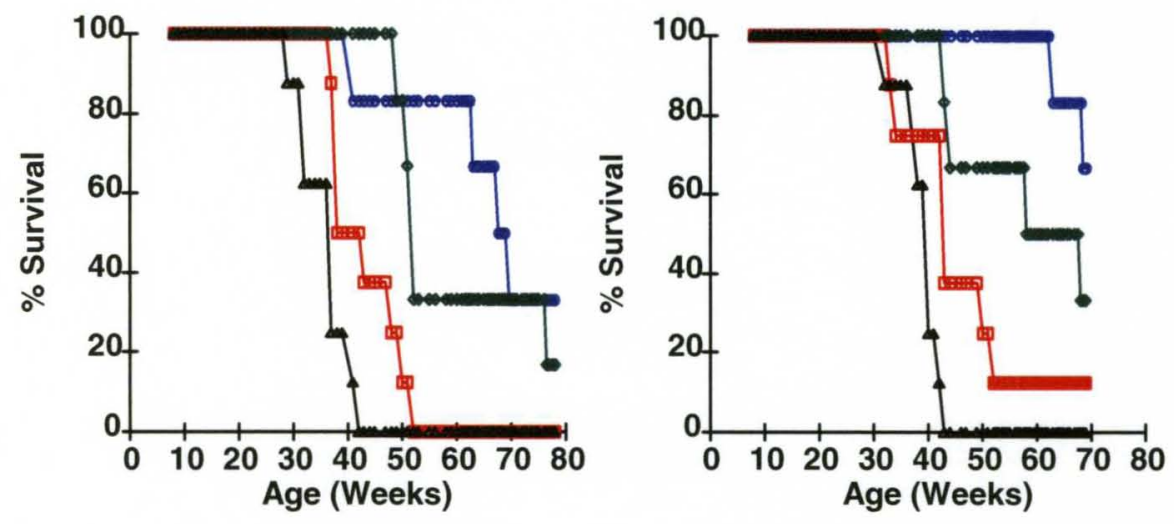
C

Expt. \#1
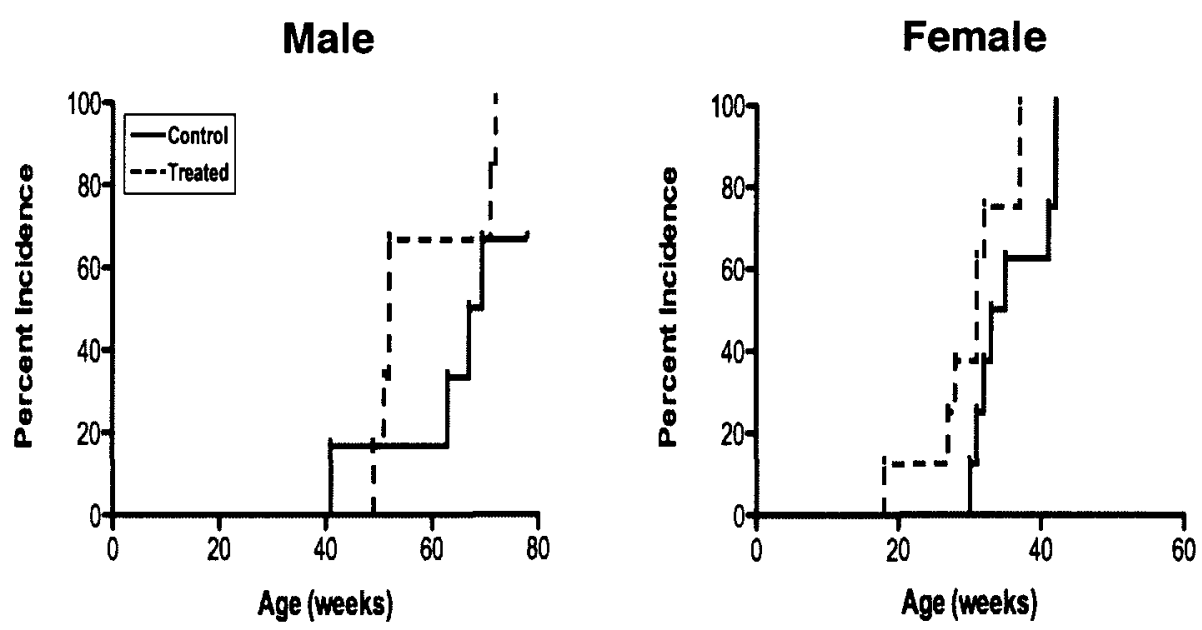

\section{Expt. \#2}

Male

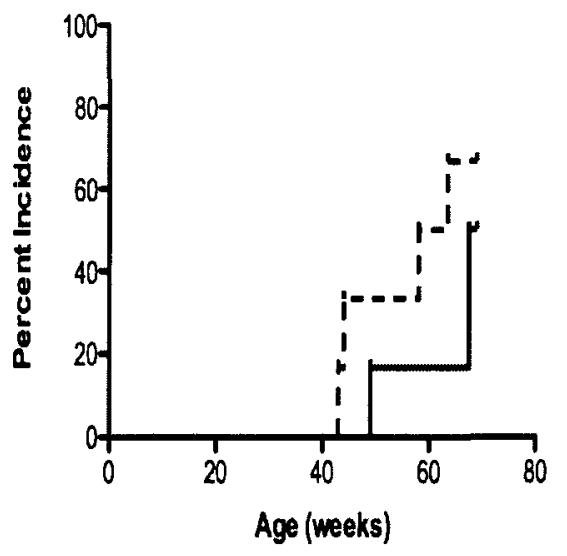

Female

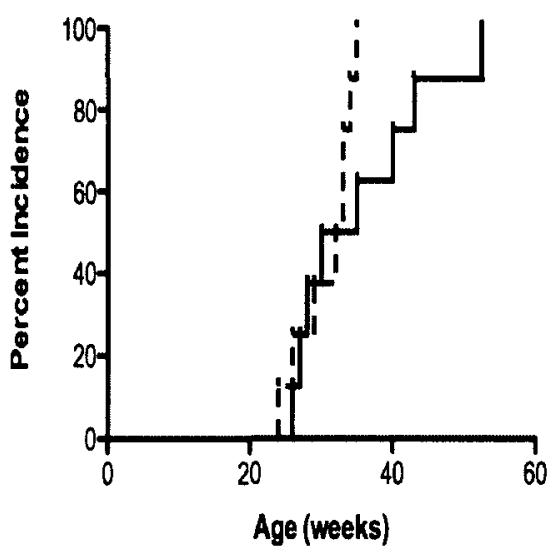


D

Expt. \#1
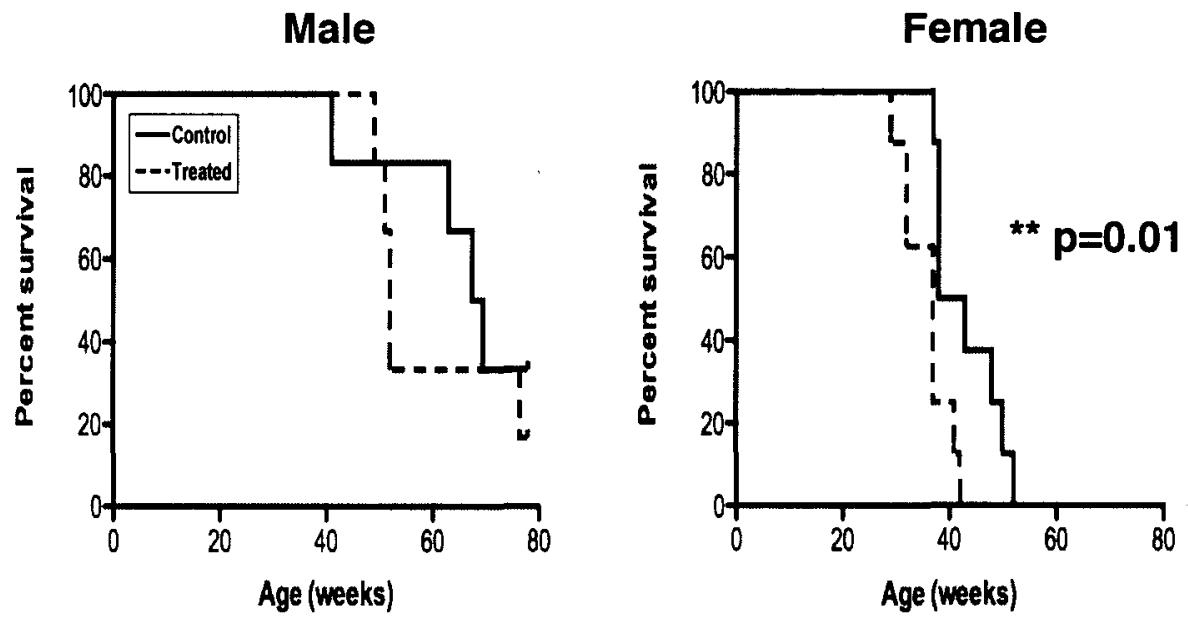

Expt. \#2

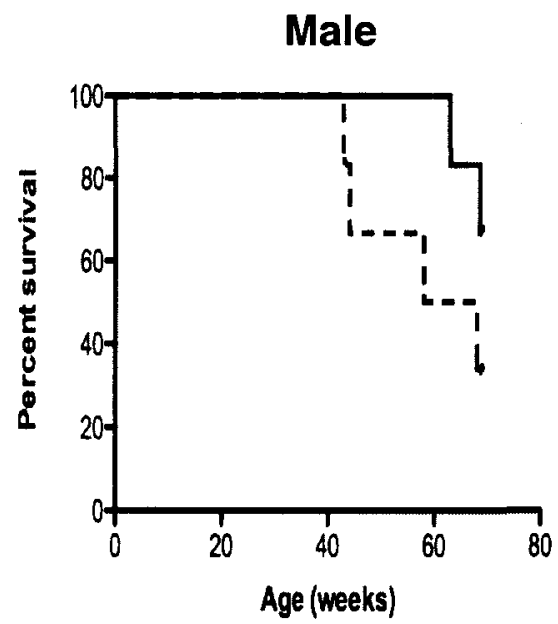

Female

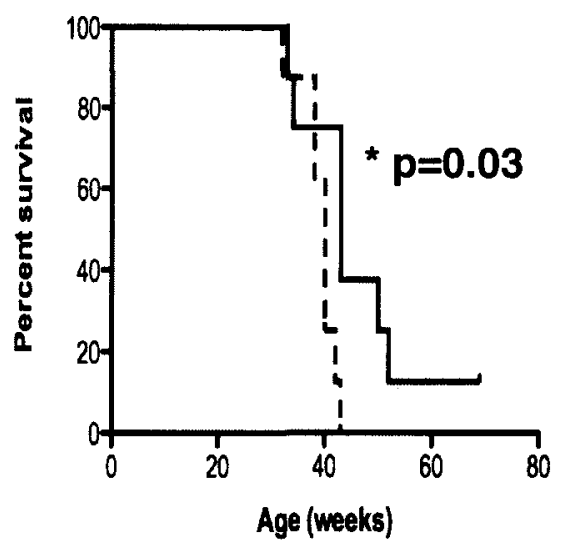

Figure 27. Disease incidence and survival in CD103-depleted BWF1 mice. Eight-wk-old female and male BWF1 mice were treated twice weekly with $0.5 \mathrm{mg}$ anti-CD103 for 4 weeks, then twice monthly until 20 wks of age. Mice were considered sick when they had a proteinuria score of 3 for two consecutive weeks. (A) Percent disease incidence. (B) Percent survival. (C) Kaplan-Meier disease incidence curves. (Experiment \#1: control vs treated male Chi square 1.266, $\mathrm{p}=0.26$; control vs treated female Chi square 3.023, 
$\mathrm{p}=0.08$; and Experiment $\# 2$ : control vs treated male Chi square $1.009, \mathrm{p}=0.32$; control vs treated female Chi square 1.812, $\mathrm{p}=0.18$ ) (D) Kaplan-Meier survival curves. (Experiment \#1: control vs treated male Chi square $0.5225, \mathrm{p}=0.47$; control vs treated female Chi square $6.682,{ }^{* *} p=0.01$; and Experiment $\# 2$ : control vs treated male Chi square 1.950, $\mathrm{p}=0.1626$; control vs treated female Chi square $4.795,{ }^{*} \mathrm{p}=0.03$ ). 


\begin{tabular}{|c|c|c|c|c|c|c|c|}
\hline & Expt. \#1 & $\begin{array}{c}\text { Expt. } \\
\# 2\end{array}$ & $\begin{array}{c}\text { Expt. } \\
\# 3\end{array}$ & Expt. \#4 & $\begin{array}{c}\text { Expt. } \\
\# 5\end{array}$ & $\begin{array}{c}\text { Expt. } \\
\# 6\end{array}$ & Expt. \#7 \\
\hline Male & & & & $\begin{array}{c}70.0 \pm \\
11.3 \\
\end{array}$ & $\begin{array}{c}39.0 \pm \\
12.0 \\
\end{array}$ & $\begin{array}{c}26.6 \pm \\
2.0 \\
\end{array}$ & \\
\hline $\begin{array}{c}\text { Non- } \\
\text { Sick } \\
\text { Female }\end{array}$ & & & & $\begin{array}{c}64.0 \pm \\
7.1\end{array}$ & $\begin{array}{c}* 68.0 \pm \\
1.0\end{array}$ & $\begin{array}{c}* 50.8 \pm \\
2.6\end{array}$ & \\
\hline \begin{tabular}{|c|} 
Sick \\
Female
\end{tabular} & & & & $\begin{array}{c}54.4 \pm \\
11.3 \\
\end{array}$ & $\begin{array}{c}28.7 \pm \\
9.6\end{array}$ & $\begin{array}{c}27.2 \pm \\
9.2 \\
\end{array}$ & \\
\hline
\end{tabular}

\begin{tabular}{|c|c|c|c|c|c|c|c|}
\hline \multicolumn{8}{|c|}{ Table 10B: LN Cell \#s $\left(\times 10^{6}\right)$} \\
\hline & Expt. \#1 & $\begin{array}{c}\text { Expt. } \\
\# 2\end{array}$ & $\begin{array}{c}\text { Expt. } \\
\# 3\end{array}$ & Expt. \#4 & $\begin{array}{c}\text { Expt. } \\
\# 5\end{array}$ & $\begin{array}{c}\text { Expt. } \\
\text { \#6 }\end{array}$ & Expt. \#7 \\
\hline Male & $\begin{array}{c}24.2 \pm \\
5.2\end{array}$ & $\begin{array}{c}17.2 \pm \\
1.2 \\
\end{array}$ & $\begin{array}{c}29.5 \pm \\
9.4\end{array}$ & $\begin{array}{c}29.5 \pm \\
9.4 \\
\end{array}$ & $\begin{array}{c}18.7 \pm \\
5.7\end{array}$ & $\begin{array}{c}39.6 \pm \\
23.5 \\
\end{array}$ & \\
\hline $\begin{array}{c}\text { Non- } \\
\text { Sick } \\
\text { Female }\end{array}$ & $\begin{array}{c}24.8 \pm \\
2.4\end{array}$ & $\begin{array}{c}22.7 \pm \\
1.8\end{array}$ & $\begin{array}{c}31.6 \pm \\
4.1\end{array}$ & $\begin{array}{c}31.6 \pm \\
4.1\end{array}$ & $\begin{array}{c}47.5 \pm \\
16.4\end{array}$ & $\begin{array}{c}20.6 \pm \\
2.5\end{array}$ & \\
\hline $\begin{array}{c}\text { Sick } \\
\text { Female }\end{array}$ & $\begin{array}{c}46.9 \pm \\
17.4 \\
\end{array}$ & $\begin{array}{c}133.1 \pm \\
74.3\end{array}$ & $\begin{array}{c}40.9 \pm \\
7.0\end{array}$ & $\begin{array}{c}40.9 \pm \\
7.0\end{array}$ & $\begin{array}{c}14.9 \pm \\
7.3 \\
\end{array}$ & $\begin{array}{c}101.4 \pm \\
52.8\end{array}$ & \\
\hline
\end{tabular}

\begin{tabular}{|c|c|c|c|c|c|c|c|}
\hline \multicolumn{8}{|c|}{ Table 10C: Spleen cell \#s $\left(\times 10^{6}\right)$} \\
\hline & Expt. \#1 & $\begin{array}{c}\text { Expt. } \\
\# 2\end{array}$ & $\begin{array}{c}\text { Expt. } \\
\# 3\end{array}$ & Expt. \#4 & $\begin{array}{c}\text { Expt. } \\
\# 5\end{array}$ & $\begin{array}{c}\text { Expt. } \\
\# 6\end{array}$ & Expt. \#7 \\
\hline Male & $\begin{array}{c}68.4 \pm \\
6.4 \\
\end{array}$ & $\begin{array}{c}68.4 \pm \\
14.5 \\
\end{array}$ & & $\begin{array}{c}66.8 \pm \\
2.1 \\
\end{array}$ & $\begin{array}{c}84.7 \pm \\
3.8 \\
\end{array}$ & $\begin{array}{c}81.7 \pm \\
24.8 \\
\end{array}$ & \\
\hline $\begin{array}{c}\text { Non- } \\
\text { Sick } \\
\text { Female } \\
\end{array}$ & $\begin{array}{c}77.8 \pm \\
9.1\end{array}$ & $\begin{array}{c}71.4 \pm \\
20.9\end{array}$ & & $\begin{array}{c}97.2 \pm \\
10.0\end{array}$ & $\begin{array}{c}178.3 \pm \\
78.0\end{array}$ & $\begin{array}{c}112.3 \pm \\
23.4\end{array}$ & \\
\hline $\begin{array}{c}\text { Sick } \\
\text { Female }\end{array}$ & $\begin{array}{c}181.0 \\
56.3\end{array} \pm$ & $\begin{array}{c}* * 216.5 \\
\pm 41.9\end{array}$ & & $\begin{array}{c}* * * 133.0 \\
\pm 7.1\end{array}$ & $\begin{array}{c}166.2 \pm \\
51.7\end{array}$ & $\begin{array}{c}175.2 \pm \\
51.5\end{array}$ & \\
\hline
\end{tabular}

\begin{tabular}{|c|c|c|c|c|c|c|c|}
\hline \multicolumn{8}{|c|}{ Table 10D: Thumus Cell \#s $\left(\times 10^{6}\right)$} \\
\hline & Expt. \#1 & $\begin{array}{c}\text { Expt. } \\
\text { \#2 }\end{array}$ & $\begin{array}{c}\text { Expt. } \\
\# 3\end{array}$ & Expt. \#4 & $\begin{array}{c}\text { Expt. } \\
\# 5\end{array}$ & $\begin{array}{c}\text { Expt. } \\
\# 6\end{array}$ & Expt. \#7 \\
\hline Male & & & & $\begin{array}{c}52.9 \pm \\
4.7\end{array}$ & $\begin{array}{c}47.6 \pm \\
19.3\end{array}$ & $\begin{array}{c}51.1 \pm \\
11.9\end{array}$ & \\
\hline $\begin{array}{c}\text { Non- } \\
\text { Sick } \\
\text { Female }\end{array}$ & & & & $\begin{array}{c}56.0 \pm \\
6.1\end{array}$ & $\begin{array}{c}41.4 \pm \\
6.8\end{array}$ & $\begin{array}{c}57.0 \pm \\
10.2\end{array}$ & \\
\hline $\begin{array}{c}\text { Sick } \\
\text { Female }\end{array}$ & & & & $\begin{array}{c}46.6 \pm \\
7.0\end{array}$ & $\begin{array}{c}9.7 \pm \\
6.5\end{array}$ & $\begin{array}{c}117.9 \pm \\
97.3\end{array}$ & \\
\hline
\end{tabular}

Table 10. Thymic weights and cell numbers in thymus, lymph nodes and spleen of 32-36week-old BWF1 mice. Thymus, lymph nodes and spleen were collected from 32-36wk old sick female, non-sick female, and male BWF1 mice and weights or cell numbers determined. Statistical differences were analyzed using a student's $t$ test or ANOVA and the Tukey-Kramer multiple comparisons test. ${ }^{*} \mathrm{p}<0.05,{ }^{* *} \mathrm{p}<0.005$, and ${ }^{* * *} \mathrm{p}<0.0005$. 


\begin{tabular}{|c|c|c|c|c|c|c|c|}
\hline Table 11A:LN MF & CD4 \\
& + & Foxp $3^{+}$ \\
& Expt. \# 1 & $\begin{array}{c}\text { Expt. } \\
\text { \#2 }\end{array}$ & $\begin{array}{c}\text { Expt. } \\
\text { \#3 }\end{array}$ & Expt. \#4 & $\begin{array}{c}\text { Expt. } \\
\text { \#5 }\end{array}$ & $\begin{array}{c}\text { Expt. } \\
\text { \#6 }\end{array}$ & Expt. \#7 \\
\hline Male & $9187.4 \pm$ & $725.4 \pm$ & $992.6 \pm$ & & $496.5 \pm$ & $467.8 \pm$ & $164.8 \pm$ \\
& 289.6 & 24.4 & 121.2 & & 120.6 & 36.3 & 7.2 \\
\hline Non- & $8966.8 \pm$ & $733.2 \pm$ & $862.2 \pm$ & & $438.8 \pm$ & $521.2 \pm$ & $148.1 \pm$ \\
Sick & 225.4 & 30.8 & 85.6 & & 14.7 & 27.0 & 4.6 \\
Female & & & & & & \\
\hline Sick & $8915.2 \pm$ & $756.7 \pm$ & $648.2 \pm$ & & $373.8 \pm$ & $473.6 \pm$ & $153.0 \pm$ \\
Female & 733.2 & 19.3 & 37.9 & & 24.3 & 23.1 & 4.9 \\
\hline
\end{tabular}

\begin{tabular}{|c|c|c|c|c|c|c|c|}
\hline \multicolumn{8}{|c|}{ Table 11B: Spleen MFI $\mathrm{CD}^{+} 4^{+} \mathrm{Oxp} 3^{+}$} \\
\hline & Expt. \#1 & $\begin{array}{c}\text { Expt. } \\
\text { \#2 }\end{array}$ & $\begin{array}{c}\text { Expt. } \\
\# 3 \\
\end{array}$ & Expt. \#4 & $\begin{array}{c}\text { Expt. } \\
\# 5\end{array}$ & $\begin{array}{c}\text { Expt. } \\
\text { \#6 }\end{array}$ & Expt. \#7 \\
\hline Male & $\begin{array}{c}7043.0 \pm \\
254.8\end{array}$ & $\begin{array}{c}643.5 \pm \\
17.2 \\
\end{array}$ & $\begin{array}{c}* 651.7 \pm \\
13.7 \\
\end{array}$ & & $\begin{array}{c}337.3 \pm \\
10.1 \\
\end{array}$ & $\begin{array}{c}542.5 \pm \\
103.9 \\
\end{array}$ & $\begin{array}{c}123.6 \pm \\
1.6 \\
\end{array}$ \\
\hline $\begin{array}{c}\text { Non- } \\
\text { Sick } \\
\text { Female }\end{array}$ & $\begin{array}{c}7549.5 \pm \\
274.5\end{array}$ & $\begin{array}{c}662.2 \pm \\
16.7\end{array}$ & $\begin{array}{c}621.1 \\
14.1\end{array}$ & & $\begin{array}{c}362.2 \pm \\
25.1\end{array}$ & $\begin{array}{c}398.7 \pm \\
22.9\end{array}$ & $\begin{array}{c}133.9 \pm \\
2.6\end{array}$ \\
\hline $\begin{array}{c}\text { Sick } \\
\text { Female }\end{array}$ & $\begin{array}{c}7317.0 \pm \\
408.2\end{array}$ & $\begin{array}{c}694.4 \pm \\
17.6\end{array}$ & $\begin{array}{c}562.7 \pm \\
23.3\end{array}$ & & $\begin{array}{c}370.8 \pm \\
8.6\end{array}$ & $\begin{array}{c}477.2 \pm \\
22.9\end{array}$ & $\begin{array}{c}139.4 \pm \\
7.3\end{array}$ \\
\hline
\end{tabular}

Table 11. Mean fluorescence intensity of Foxp3 on $\mathrm{CD}^{+}$cells in 32-36-week-old BWF1 mice. Cells from lymph nodes (LN) and spleen of 32-36-week-old sick female, non-sick female, and male BWF1 mice were labeled with anti-CD4 and anti-Foxp3 antibodies and analyzed by $\mathrm{FACS}^{\circledast}$. Labeled $\mathrm{CD}^{+}$cells were gated and analyzed for the per cell expression of Foxp3 in (A) LN and (B) spleen. Statistical differences were analyzed using a student's $t$ test or ANOVA and the Tukey-Kramer multiple comparisons test. * $\mathrm{p}<0.05,{ }^{* *} \mathrm{p}<0.005$, and ${ }^{* * *} \mathrm{p}<0.0005$. 


\begin{tabular}{|c|c|c|c|c|c|c|c|}
\hline \multicolumn{8}{|c|}{ Table 12A: LN CD4 ${ }^{+} \mathrm{CD} 25^{+} \mathrm{CD} 103^{+}$Cell \#s $\left(\times 10^{6}\right)$} \\
\hline & Expt. \#1 & $\begin{array}{c}\text { Expt. } \\
\text { \#2 }\end{array}$ & $\begin{array}{c}\text { Expt. } \\
\# 3\end{array}$ & Expt. \#4 & $\begin{array}{c}\text { Expt. } \\
\# 5\end{array}$ & $\begin{array}{c}\text { Expt. } \\
\text { \#6 }\end{array}$ & Expt. \#7 \\
\hline Male & $\begin{array}{c}0.050 \pm \\
0.014 \\
\end{array}$ & $\begin{array}{c}0.084 \pm \\
0.022 \\
\end{array}$ & $\begin{array}{c}* 0.083 \pm \\
0.031 \\
\end{array}$ & $\begin{array}{c}0.122 \pm \\
0.078 \\
\end{array}$ & $\begin{array}{c}0.076 \pm \\
0.017\end{array}$ & $\begin{array}{c}0.416 \pm \\
0.343\end{array}$ & \\
\hline $\begin{array}{c}\text { Non- } \\
\text { Sick } \\
\text { Female }\end{array}$ & $\begin{array}{c}0.054 \pm \\
0.009\end{array}$ & $\begin{array}{c}0.122 \pm \\
0.048\end{array}$ & $\begin{array}{c}0.086 \pm \\
0.016\end{array}$ & $\begin{array}{c}0.090 \pm \\
0.029\end{array}$ & $\begin{array}{c}0.585 \pm \\
0.392\end{array}$ & $\begin{array}{c}0.095 \pm \\
0.014\end{array}$ & \\
\hline $\begin{array}{c}\text { Sick } \\
\text { Female }\end{array}$ & $\begin{array}{c}0.273 \pm \\
0.139 \\
\end{array}$ & $\begin{array}{c}3.282 \pm \\
1.995\end{array}$ & $\begin{array}{c}0.863 \pm \\
0.325\end{array}$ & $\begin{array}{c}0.403 \pm \\
0.144 \\
\end{array}$ & $\begin{array}{c}0.110 \pm \\
0.056 \\
\end{array}$ & $\begin{array}{c}2.095 \pm \\
1.211 \\
\end{array}$ & \\
\hline
\end{tabular}

\begin{tabular}{|c|c|c|c|c|c|c|c|}
\hline \multicolumn{8}{|c|}{ Table 12B: Spleen $\mathrm{CD}^{+} \mathrm{CD} 25^{+} \mathrm{CD} 103^{+}$Cell \#s $\left(\times 10^{6}\right)$} \\
\hline & Expt. \# 1 & $\begin{array}{c}\text { Expt. } \\
\text { \#2 }\end{array}$ & $\begin{array}{c}\text { Expt. } \\
\text { \#3 }\end{array}$ & Expt. \#4 & $\begin{array}{c}\text { Expt. } \\
\text { \#5 }\end{array}$ & $\begin{array}{c}\text { Expt. } \\
\# 6\end{array}$ & Expt. \#7 \\
\hline Male & $\begin{array}{c}* 0.133 \pm \\
0.032\end{array}$ & $\begin{array}{r}* * 0.261 \\
\pm 0.105\end{array}$ & & $\begin{array}{c}* * * 0.105 \\
\pm 0.029\end{array}$ & $\begin{array}{c}0.343 \pm \\
0.113\end{array}$ & $\begin{array}{c}1.343 \pm \\
0.610\end{array}$ & \\
\hline $\begin{array}{c}\text { Non- } \\
\text { Sick } \\
\text { Female }\end{array}$ & $\begin{array}{c}0.193 \pm \\
0.038\end{array}$ & $\begin{array}{c}0.509 \pm \\
0.300\end{array}$ & & $\begin{array}{c}0.266 \pm \\
0.060\end{array}$ & $\begin{array}{c}2.632 \pm \\
2.049\end{array}$ & $\begin{array}{c}2.051 \pm \\
0.524\end{array}$ & \\
\hline $\begin{array}{c}\text { Sick } \\
\text { Female }\end{array}$ & $\begin{array}{c}1.051 \pm \\
0.401\end{array}$ & $\begin{array}{c}3.986 \pm \\
1.196\end{array}$ & & $\begin{array}{c}1.246 \pm \\
0.280\end{array}$ & $\begin{array}{c}2.097 \pm \\
1.043\end{array}$ & $\begin{array}{c}5.885 \pm \\
2.483\end{array}$ & \\
\hline
\end{tabular}

Table 12. Numbers of $\mathrm{CD}^{+} \mathrm{CD} 25^{+} \mathrm{CD} 103^{+}$cells in 32-36-week-old BWF1 mice. Cells from lymph nodes (LN), spleen, and thymus of 32-36-week-old sick female, non-sick female, and male BWF1 mice were labeled with anti-CD4, anti-CD25, and anti-CD103 antibodies and analyzed by $\mathrm{FACS}{ }^{\otimes}$. The total numbers of $\mathrm{CD}^{+} \mathrm{CD} 25^{+} \mathrm{CD} 103^{+}$cells are shown in (A) LN, (B) spleen, and (C) thymus. Statistical differences were analyzed using a student's $\mathrm{t}$ test or ANOVA and the Tukey-Kramer multiple comparisons test. ${ }^{*} \mathrm{p}<0.05$, ${ }^{* *} \mathrm{p}<0.005$, and $^{* * *} \mathrm{p}<0.0005$ 


\begin{tabular}{|c|c|c|c|c|c|c|c|}
\hline & Expt. \#1 & $\begin{array}{c}\text { Expt. } \\
\text { \#2 }\end{array}$ & $\begin{array}{c}\text { Expt. } \\
\# 1\end{array}$ & Expt. \#4 & $\begin{array}{c}\text { Expt. } \\
\# 5\end{array}$ & $\begin{array}{c}\text { Expt. } \\
\# 6\end{array}$ & Expt. \#7 \\
\hline Male & $\begin{array}{c}56.2 \pm \\
1.4 \\
\end{array}$ & $\begin{array}{c}46.6 \pm \\
1.2 \\
\end{array}$ & $\begin{array}{c}46.5 \pm \\
2.1 \\
\end{array}$ & $\begin{array}{c}45.0 \pm \\
5.9\end{array}$ & $\begin{array}{c}49.6 \pm \\
6.0\end{array}$ & $\begin{array}{c}49.6 \pm \\
3.7 \\
\end{array}$ & $\begin{array}{c}57.4 \pm \\
1.9 \\
\end{array}$ \\
\hline $\begin{array}{c}\text { Non- } \\
\text { Sick } \\
\text { Female }\end{array}$ & $\begin{array}{c}54.4 \pm \\
2.1\end{array}$ & $\begin{array}{c}46.7 \pm \\
3.1\end{array}$ & $\begin{array}{c}54.9 \pm \\
1.4\end{array}$ & $\begin{array}{c}46.6 \pm \\
3.4\end{array}$ & $\begin{array}{c}51.5 \pm \\
1.8\end{array}$ & $\begin{array}{c}54.7 \pm \\
2.3\end{array}$ & $\begin{array}{c}61.3 \pm \\
1.1\end{array}$ \\
\hline $\begin{array}{c}\text { Sick } \\
\text { Female }\end{array}$ & $\begin{array}{c}* * 47.2 \pm \\
1.7 \\
\end{array}$ & $\begin{array}{c}45.5 \pm \\
2.8 \\
\end{array}$ & $\begin{array}{c}51.5 \pm \\
2.2\end{array}$ & $\begin{array}{c}37.6 \pm \\
4.2\end{array}$ & $\begin{array}{c}49.8 \pm \\
2.9\end{array}$ & $\begin{array}{c}44.9 \pm \\
3.9 \\
\end{array}$ & $\begin{array}{c}52.2 \pm \\
4.0 \\
\end{array}$ \\
\hline
\end{tabular}

\begin{tabular}{|c|c|c|c|c|c|c|c|}
\hline \multicolumn{8}{|c|}{ Table 13B: Spleen \% CD4 ${ }^{+}$} \\
\hline & Expt. \#1 & $\begin{array}{c}\text { Expt. } \\
\# 2\end{array}$ & $\begin{array}{c}\text { Expt. } \\
\# 3\end{array}$ & Expt. \#4 & $\begin{array}{c}\text { Expt. } \\
\# 5\end{array}$ & $\begin{array}{c}\text { Expt. } \\
\# 6\end{array}$ & Expt. \#7 \\
\hline Male & $\begin{array}{c}* * 30.7 \pm \\
0.5\end{array}$ & $\begin{array}{c}26.0 \pm \\
1.1 \\
\end{array}$ & $\begin{array}{c}* 28.7 \pm \\
0.9\end{array}$ & $\begin{array}{c}25.7 \pm \\
0.7\end{array}$ & $\begin{array}{c}28.3 \pm \\
2.1 \\
\end{array}$ & $\begin{array}{c}29.6 \pm \\
0.6\end{array}$ & $\begin{array}{c}25.9 \pm \\
1.4 \\
\end{array}$ \\
\hline $\begin{array}{c}\text { Non- } \\
\text { Sick } \\
\text { Female }\end{array}$ & $\begin{array}{c}35.3 \pm \\
0.9\end{array}$ & $\begin{array}{c}28.7 \pm \\
1.7\end{array}$ & $\begin{array}{c}35.6 \pm \\
0.8\end{array}$ & $\begin{array}{c}27.3 \pm \\
2.6\end{array}$ & $\begin{array}{c}32.7 \pm \\
3.6\end{array}$ & $\begin{array}{c}31.4 \pm \\
1.7\end{array}$ & $\begin{array}{c}29.5 \pm \\
0.9\end{array}$ \\
\hline $\begin{array}{c}\text { Sick } \\
\text { Female }\end{array}$ & $\begin{array}{c}34.5 \pm \\
0.6\end{array}$ & $\begin{array}{c}28.1 \pm \\
2.9\end{array}$ & $\begin{array}{c}35.6 \pm \\
2.2\end{array}$ & $\begin{array}{c}22.3 \pm \\
0.7\end{array}$ & $\begin{array}{c}28.9 \pm \\
1.4\end{array}$ & $\begin{array}{c}29.4 \pm \\
2.1\end{array}$ & $\begin{array}{c}27.2 \pm \\
3.5\end{array}$ \\
\hline
\end{tabular}

\begin{tabular}{|c|c|c|c|c|c|c|c|}
\hline \multicolumn{8}{|c|}{ 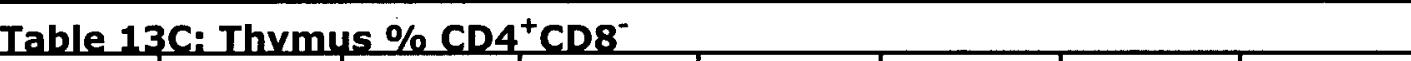 } \\
\hline & Expt. \#1 & $\begin{array}{c}\text { Expt. } \\
\# 2\end{array}$ & $\begin{array}{c}\text { Expt. } \\
\text { \#3 }\end{array}$ & Expt. \#4 & $\begin{array}{c}\text { Expt. } \\
\text { \#5 }\end{array}$ & $\begin{array}{c}\text { Expt. } \\
\# 6\end{array}$ & Expt. \#7 \\
\hline Male & $\begin{array}{c}10.2 \pm \\
0.5\end{array}$ & & $\begin{array}{c}18.0 \pm \\
0.7\end{array}$ & $8.2 \pm 0.3$ & & $\begin{array}{c}17.4 \pm \\
4.1\end{array}$ & \\
\hline $\begin{array}{c}\text { Non- } \\
\text { Sick } \\
\text { Female }\end{array}$ & $8.9 \pm 0.6$ & & $\begin{array}{c}13.0 \pm \\
1.6\end{array}$ & $8.2 \pm 0.2$ & & $\begin{array}{c}17.3 \pm \\
3.0\end{array}$ & \\
\hline $\begin{array}{c}\text { Sick } \\
\text { Female }\end{array}$ & $\begin{array}{c}* * 36.3 \pm \\
8.2\end{array}$ & & $\begin{array}{c}5.3 \pm \\
0.7\end{array}$ & $\begin{array}{c}* * 13.7 \pm \\
2.0\end{array}$ & & $\begin{array}{c}* * 36.8 \pm \\
4.2\end{array}$ & \\
\hline
\end{tabular}

Table 13. Percentages of $\mathrm{CD}^{+}$cells in 32-36-week-old BWF1 mice. Cells from lymph nodes (LN), spleen, and thymus of 32-36-week-old sick female, non-sick female, and male BWF1 mice were labeled with anti-CD4 antibody and analyzed by FACS ${ }^{\circledast}$. Labeled $T$ cells were gated and analyzed for the percentages of cells expressing CD4 in (A) LN, (B) spleen, and (C) thymus. Statistical differences were analyzed using a student's t test or ANOVA and the Tukey-Kramer multiple comparisons test. ${ }^{*} \mathrm{p}<0.05,{ }^{* *} \mathrm{p}<0.005$, and $* * * \mathrm{p}<0.0005$. 


\begin{tabular}{|c|c|c|c|c|c|c|c|}
\hline \multicolumn{8}{|c|}{ Table 14A: LN CD4 ${ }^{+}$Cell \#s $\left(\times 10^{6}\right)$} \\
\hline & Expt. \#1 & $\begin{array}{c}\text { Expt. } \\
\# 2\end{array}$ & $\begin{array}{c}\text { Expt. } \\
\# 3\end{array}$ & Expt. \#4 & $\begin{array}{c}\text { Expt. } \\
\# 5\end{array}$ & $\begin{array}{c}\text { Expt. } \\
\# 6\end{array}$ & Expt. \#7 \\
\hline Male & $\begin{array}{c}9.890 \pm \\
1.784 \\
\end{array}$ & $\begin{array}{c}7.039 \pm \\
0.663 \\
\end{array}$ & \begin{tabular}{|c|}
$11.347 \pm$ \\
3.888 \\
\end{tabular} & & \begin{tabular}{|c|}
$8.435 \pm$ \\
3.409 \\
\end{tabular} & $\begin{array}{c}15.878 \pm \\
7.704 \\
\end{array}$ & \\
\hline $\begin{array}{c}\text { Non- } \\
\text { Sick } \\
\text { Female }\end{array}$ & $\begin{array}{c}10.367 \pm \\
1.357\end{array}$ & $\begin{array}{c}9.419 \pm \\
0.981\end{array}$ & $\begin{array}{c}14.266 \pm \\
2.844\end{array}$ & & $\begin{array}{c}18.999 \pm \\
5.751\end{array}$ & $\begin{array}{c}10.371 \\
1.505\end{array}$ & \\
\hline $\begin{array}{c}\text { Sick } \\
\text { Female }\end{array}$ & $\begin{array}{c}14.726 \pm \\
5.476\end{array}$ & $\begin{array}{c}48.773 \pm \\
25.196\end{array}$ & $\begin{array}{c}17.188 \pm \\
1.531\end{array}$ & & $\begin{array}{c}5.647 \pm \\
2.600\end{array}$ & $\begin{array}{c}36.911 \pm \\
17.721\end{array}$ & \\
\hline
\end{tabular}

\begin{tabular}{|c|c|c|c|c|c|c|c|}
\hline \multicolumn{8}{|c|}{ Table 14B: Spleen CD4 $4^{+}$Cell \#s $\left(\times 10^{6}\right)$} \\
\hline & Expt. \#1 & $\begin{array}{c}\text { Expt. } \\
\# 2\end{array}$ & $\begin{array}{c}\text { Expt. } \\
\text { \#3 }\end{array}$ & Expt. \#4 & $\begin{array}{c}\text { Expt. } \\
\text { \#5 }\end{array}$ & $\begin{array}{c}\text { Expt. } \\
\# 6\end{array}$ & Expt. \#7 \\
\hline Male & \begin{tabular}{|c|}
$14.194 \pm$ \\
1.491 \\
\end{tabular} & \begin{tabular}{|c|}
$14.865 \pm$ \\
2.688 \\
\end{tabular} & & & $\begin{array}{c}18.991 \pm \\
1.703 \\
\end{array}$ & \begin{tabular}{|c|}
$23.254 \pm$ \\
6.562 \\
\end{tabular} & \\
\hline $\begin{array}{c}\text { Non- } \\
\text { Sick } \\
\text { Female }\end{array}$ & $\begin{array}{c}15.445 \pm \\
2.009\end{array}$ & $\begin{array}{c}15.735 \pm \\
3.201\end{array}$ & & & $\begin{array}{c}37.557 \pm \\
15.696\end{array}$ & $\begin{array}{c}33.051 \pm \\
5.299\end{array}$ & \\
\hline $\begin{array}{c}\text { Sick } \\
\text { Female }\end{array}$ & $\begin{array}{c}29.019 \pm \\
9.438\end{array}$ & $\begin{array}{c}* 50.41 \\
2 \pm \\
10.460\end{array}$ & & & $\begin{array}{c}33.886 \pm \\
8.833\end{array}$ & $\begin{array}{c}47.835 \pm \\
13.878\end{array}$ & \\
\hline
\end{tabular}

\begin{tabular}{|c|c|c|c|c|c|c|c|}
\hline \multicolumn{8}{|c|}{ Table 14C: Thymus CD4 ${ }^{+}$CD8- Cell \#s $\left(\times 10^{6}\right)$} \\
\hline & Expt. \#1 & $\begin{array}{c}\text { Expt. } \\
\# 2\end{array}$ & $\begin{array}{c}\text { Expt. } \\
\# 3\end{array}$ & Expt. \#4 & $\begin{array}{c}\text { Expt. } \\
\# 5\end{array}$ & $\begin{array}{c}\text { Expt. } \\
\text { \#6 }\end{array}$ & Expt. \#7 \\
\hline Male & & & $\begin{array}{c}2.373 \pm \\
0.389\end{array}$ & & & $\begin{array}{c}7.231 \pm \\
1.136\end{array}$ & \\
\hline $\begin{array}{c}\text { Non- } \\
\text { Sick } \\
\text { Female }\end{array}$ & & & $\begin{array}{c}1.609 \pm \\
0.538\end{array}$ & & & $\begin{array}{c}8.678 \pm \\
0.709\end{array}$ & \\
\hline $\begin{array}{c}\text { Sick } \\
\text { Female }\end{array}$ & & & $\begin{array}{l}* * 0.271 \\
\pm 0.059\end{array}$ & & & $\begin{array}{c}28030 \pm \\
20.190\end{array}$ & \\
\hline
\end{tabular}

Table 14. Numbers of $\mathrm{CD}^{+}$cells in 32-36-week-old BWF1 mice. Cells from lymph nodes (LN), spleen, and thymus of 32-36-week-old sick female, non-sick female, and male BWF1 mice were labeled with anti-CD4 antibody and analyzed by FACS ${ }^{\circledast}$. The total numbers of $\mathrm{CD}^{+}$cells are shown in (A) LN, (B) spleen, and (C) thymus. Statistical differences were analyzed using a student's $t$ test or ANOVA and the Tukey-Kramer multiple comparisons test. ${ }^{*} \mathrm{p}<0.05,{ }^{* *} \mathrm{p}<0.005$, and ${ }^{* * *} \mathrm{p}<0.0005$. 


\section{DISCUSSION}

Regulatory $\mathrm{T}$ cells have been shown to be important in controlling autoimmune disease $(123,124)$. Females are generally more susceptible to autoimmune disease, including systemic lupus erythematosus (SLE), in which women are nine times more likely to develop disease than men (1). We hypothesized that gender differences in regulatory $\mathrm{T}$ cell populations are associated with differences in disease susceptibility. We used a spontaneous mouse model of SLE, (NZBxNZW)F1 (BWF1), in which females predominantly develop disease, to investigate gender differences in regulatory $\mathrm{T}$ cell populations. We also compared Treg populations in autoimmune-prone BWF1 mice to other autoimmune-prone and more resistant strains.

\section{Strain differences in regulatory $T$ cell percentages correlate with disease susceptibility.}

Strains of mice with different genetic backgrounds have varying susceptibility to disease. Previous studies have found differences in regulatory $\mathrm{T}$ cell populations, either in number or function, between "more" and "less susceptible" strains $(244,254,255)$. In a 2005 study by Howard and colleagues, the authors describe C57BL/6 mice as more susceptible to autoimmune disease than BALB/c mice and show that $\mathrm{C} 57 \mathrm{BL} / 6$ mice have significantly lower percentages of $\mathrm{CD} 4^{+} \mathrm{CD} 25^{+}$Tregs in the thymus and peripheral 
lymphoid organs than BALB/c mice (254). We also found that BALB/c mice had a higher percentage of Tregs (although we used the more specific Treg marker, Foxp3, to distinguish Tregs) than C57BL/6 mice in thymus, LN, and spleen (Figure 2A). Whereas it is true that autoimmune disease can be induced in C57BL/6 mice (i.e. MOG-induced EAE (261)), it can also be induced in BALB/c mice (i.e. collagen-induced arthritis (262)), and by comparison to other strains, such as the highly autoimmune-prone strains, BWF1 and SJL mice, the C57BL/6 and BALB/c strains of mice rank extremely low on the autoimmune disease susceptibility scale. We, therefore, believe that it is significant that lupus-prone BWF1 mice had dramatically lower percentages of Tregs than the other three strains studied (Figure 2A). With regard to functional differences in Tregs between strains, Chen et al. found apparent differences in Treg suppressive function between $\mathrm{C} 57 \mathrm{BL} / 6$ and $\mathrm{BALB} / \mathrm{c}$ mice in vitro (254). When cultured with syngeneic $\mathrm{CD} 4^{+} \mathrm{CD} 25^{-}$ responder cells, C57BL/6 $\mathrm{CD} 4{ }^{+} \mathrm{CD} 25^{+}$Tregs did not suppress as well as $\mathrm{CD} 4^{+} \mathrm{CD} 25^{+}$ $\mathrm{BALB} / \mathrm{c}$ Tregs, and the difference in suppressive function between C57BL/6 and $\mathrm{BALB} / \mathrm{c}$ Tregs was due to the increased resistance of $\mathrm{C} 57 \mathrm{BL} / 6 \mathrm{CD} 4^{+} \mathrm{CD} 25^{-}$responder cells to suppression (254). We found no differences in the suppressive ability of $\mathrm{CD} 4^{+} \mathrm{CD} 25^{+}$Tregs between any of the four strains studied when co-cultured with either syngeneic or $\mathrm{C} 57 \mathrm{BL} / 6 \mathrm{CD} 4^{+} \mathrm{CD} 25^{-}$responder cells (Figure 1). Furthermore, C57BL/6 responder cells seemed to be as sensitive to suppression as responder cells from any of the three other strains. We cannot account for these differences other than to suggest that there may be differences in protocol or mouse colony conditions. Morel and colleagues also found $\mathrm{CD} 4^{+} \mathrm{CD} 25^{\circ}$ resistance to suppression in NZB2410 mice, a congenic mouse model on a C57BL/6 background that expresses the lupus susceptibility locus Sle1a of 
BWF1 mice (115). They found that high levels of IL-6 produced by bone marrow-derived DCs rendered $\mathrm{CD} 4^{+} \mathrm{CD} 25$ responder cells resistant to suppression by Tregs (115). In our study, we did not see any evidence of resistance of BWF1 responders to suppression by Tregs or evidence that the female BWF 1 APCs were any more capable of conferring any kind of resistance onto the responders (Figure 14B \& 14C, 25B). The discrepancies in the results between the studies could be due to 1) the APCs that we tested in the BWF1 model were endogenous spleen cells and not the bone marrow-derived DC that Morel and colleagues tested and 2) the mouse model used by the Morel group was a congenic strain of BWF1 that was primarily on a C57BL/6 background.

While other groups have looked at regulatory $\mathrm{T}$ cell populations in different strains of mice, and even compared autoimmune-prone and less autoimmune-prone strains of mice, they have not systematically studied the $\mathrm{CD} 103^{+}$Treg subset in these mouse strains. $\mathrm{CD} 03^{+}$Tregs are a very potent subset of Tregs that are thought to have a memory/effector phenotype and are found in both mice and humans (207-210). These $\mathrm{CD}_{103^{+}}$Tregs are better suppressors both in vitro and in vivo than CD103- Tregs (149, 207, 211). We found that both autoimmune-prone strains, BWF1 and SJL, have lower percentages of $\mathrm{CD}^{+} \mathrm{CD} 25^{+} \mathrm{CD} 103^{+}$Tregs in $\mathrm{LN}$ than the less autoimmune-prone strains, C57BL/6 and BALB/c (Figure 3A). Again we found no difference in the ability of $\mathrm{CD} 4^{+} \mathrm{CD} 25^{+} \mathrm{CD} 103^{+}$Tregs to suppress syngeneic $\mathrm{CD} 4^{+} \mathrm{CD} 25^{-}$responder cells between strains in vitro (Figure 3D). These data suggest that lower Treg ratios may be important in disease susceptibility.

Reddy et al. have reported that while SJL mice, which are susceptible to PLP 139151-induced EAE, and B10.S mice, which are resistant to PLP 139-151-induced EAE, 
have similar percentages of $\mathrm{CD} 4^{+} \mathrm{CD} 25^{+}$Tregs, B10.S mice have a $3 \mathrm{X}$ higher PLP 139151 antigen-specific Treg to antigen-specific effector T cell ratio than SJL mice, (263). When $\mathrm{CD} 4^{+} \mathrm{CD} 25^{+}$Tregs in B10.S mice were eliminated using a depleting CD25 antibody, antigen-specific effector $\mathrm{T}$ cells were uncontrolled and able to proliferate, causing these mice to develop EAE (263). These data support the hypothesis that reduced percentages of Tregs in BWF1 mice, when compared to other mouse strains, may be unable to control autoreactive $\mathrm{T}$ cell proliferation and expansion well enough to prevent disease. We found no significant differences in homeostatic proliferation of $\mathrm{CD}^{+} \mathrm{Foxp}^{-}$ effector T cells in vivo between strains in young mice (Figure 5B). However, since we do not have the tools to analyze antigen-specific $\mathrm{T}$ cells in wildtype mice, we cannot rule out the possibility that autoreactive $\mathrm{T}$ cells are proliferating more in autoimmune-prone mice.

\section{Gender differences in regulatory $T$ cell percentages in autoimmune-prone and less autoimmune-prone mouse strains.}

Women are more susceptible to many autoimmune diseases than men (1). This is especially true for systemic lupus erythematosus $(49,50)$. Females have a stronger immune response in general compared to males. They produce higher antibody titers in response to antigens (6), have more activated T cells (7), and produce more IFN- $\gamma$ in response to antigens (10). In fact, inflammatory cytokine production is increased when $\mathrm{CD}^{+} \mathrm{T}$ cells are treated with estradiol and decreased when treated with the androgen in vitro $(11,12)$. Exposure to estrogens, either produced naturally in females or present in estrogenic compounds such as oral contraceptives and fertilizers, has been associated with an increased risk of autoimmune disease (13). Androgens have been shown to be 
protective in some autoimmune disease settings. Treatment of SJL mice with adoptively transferred EAE with DHT 90-day release pellets resulted in less severe and eventually remitting disease (31). Castration of male non-obese diabetic (NOD), a mouse model of type 1 diabetes and (NZBxNZW)F1 (BWF1) mice resulted in disease similar to that seen in females $(40,68)$. Androgen treatment of female NOD or BWF1 mice protects these mice from disease $(39,68)$. The BWF1 mouse model of lupus mirrors human disease in two ways: first, disease develops spontaneously, and second, BWF1 mice also have a female bias for development of disease $(66,67)$. We evaluated 9-week-old female and male BWF1 mice, which do not yet exhibit disease symptoms (e.g., circulating dsDNA antibodies and proteinuria) to investigate gender differences in Treg populations. We also looked at female and male Treg populations in age-matched mice from three other strains, another autoimmune-prone strain, SJL, and two less autoimmune-prone strains, C57BL/6 and BALB/c. We found that of all four strains studied, only BWF1 females had lower percentages and numbers of $\mathrm{CD}^{+}{ }^{+} \mathrm{Foxp} 3^{+}$Tregs than males in the periphery (Figure 9A \& 9B). $\mathrm{CD} 4^{+} \mathrm{CD} 25^{+}$regulatory cells have been shown to be important in disease prevention in BWF1 mice, since depletion of these cells by anti-CD25 antibody treatment (i.e. Treg depletion) in vivo significantly accelerates disease (174). In another mouse model of lupus, NZM2328, removal of Tregs through pre-pubertal thymectomy also accelerated disease and adoptive transfer of $\mathrm{CD} 25^{+}$Tregs from non-sick mice could rescue from disease (175). These data support our hypothesis that the reduction we see in $\mathrm{CD}^{+}{ }^{+}$Foxp $3^{+}$Tregs in female BWF1 mice when compared to males may be an important contributing factor to their increased disease susceptibility. 
Females of all four strains we studied had lower percentages and numbers of $\mathrm{CD} 4^{+} \mathrm{CD} 25^{+} \mathrm{CD} 103^{+}$Tregs in the periphery (Figure 10A, Table 7). This is interesting and may suggest that the potent $\mathrm{CD} 4^{+} \mathrm{CD} 25^{+} \mathrm{CD} 103^{+}$subset of Tregs is sensitive to hormonal influences. We found no differences in either $\mathrm{CD} 4^{+} \mathrm{CD} 25^{+}$or $\mathrm{CD} 4^{+} \mathrm{CD} 25^{+} \mathrm{CD} 103^{+}$Treg function in vitro between young female and male BWF1 mice (Figure 8,10D), suggesting that it may be the decreased ratio of Tregs:Teffector cells and not a defect in inherent suppressive function that increases female disease incidence.

Natural Tregs develop in the thymus through positive selection on a high affinity TCR (185). In all four strains studied, we saw no differences between female and male thymic percentages or numbers of either $\mathrm{CD} 4^{+} \mathrm{Foxp} 3^{+}$Tregs or the $\mathrm{CD} 4^{+} \mathrm{CD} 25^{+} \mathrm{CD} 103^{+}$ subset of Tregs (Figure 11), indicating that there was no defect in thymic production of these cells. It is true that Tregs can develop extra-thymically through conversion in the periphery $(190,191)$, and it would be interesting to compare female and male conversion both in vitro and in vivo, especially in the BWF1 mice, in the future to determine whether female BWF1 mice, or BWF1 mice in general compared to other mouse strains, have a defect in conversion.

We looked at proliferation in vivo of $\mathrm{CD} 4^{+} \mathrm{Foxp} 3^{+}$Tregs, $\mathrm{CD} 4^{+} \mathrm{CD} 25^{+} \mathrm{CD} 103^{+}$ Tregs, and $\mathrm{CD}^{+}{ }^{+} \mathrm{Foxp}^{-}{ }^{-}$non-Tregs from 9-week-old mice. The only strain with gender differences in proliferation ratios of $\mathrm{CD}^{+} \mathrm{Foxp}^{+}: \mathrm{CD}^{+}{ }^{+}$Foxp $3^{-} \mathrm{T}$ cells was the BWF 1 strain (Figure 12D). Female BWF1 mice had a lower $\mathrm{CD} 4^{+} \mathrm{Foxp}^{+}{ }^{+} \mathrm{CD}^{+}{ }^{+} \mathrm{Foxp} 3^{-}$ proliferation ratio than BWF1 males in the $\mathrm{LN}$ because the Foxp $3^{-}$cells were proliferating more and not because the Foxp $3^{+}$cells were proliferating less in females (Figure 12). So the question becomes, are the Foxp3 $3^{-}$effector cells proliferating in 
female BWF1 mice because there are too few Foxp $3^{+}$Tregs to control them or are the Tregs dysfunctional thus allowing the Foxp $3^{-}$effector cells to proliferate and creating the imbalance in the Foxp3 $3^{+}$:Foxp3 $3^{-}$ratio. Perhaps by looking at earlier time-points in BWF1 mice we may be able to distinguish between these two possibilities.

Hormones impact the development of autoimmune disease. It has been shown that castration of male BWF1 mice induces disease comparable to female disease (68). Estrogen treatment of castrated male or ovariectomized BWF1 mice increases disease severity while androgen treatment protects from disease (68). Though we don't understand the mechanism, our lab has also found that androgen-treated BWF1 females have increased Treg percentages, both $\mathrm{CD} 4{ }^{+} \mathrm{CD} 25^{+}$and $\mathrm{CD} 4{ }^{+} \mathrm{CD} 25^{+} \mathrm{CD} 103^{+}$Treg subsets, comparable to levels seen in age-matched males, and that castrated male Treg percentages are comparable to percentages found in females (unpublished data). We hypothesize that androgens in males increase the numbers (perhaps by increasing survival or conversion/induction of these cells), and possibly the function, of Tregs by comparison to females, and it is through this mechanism, at least in part, that androgens protect males from the development of autoimmune disease even when they have a genetic predisposition for disease, as in BWF1 mice.

\section{Regulatory $\mathbf{T}$ cell populations change with disease progression.}

Regulatory $\mathrm{T}$ cell populations have been shown to be important in systemic lupus erythematosus (SLE) in both humans and mice $(160,161)$. In humans, some studies have found reduced Treg percentages and function in SLE patients (162-164), whereas other studies have found reduced percentages, but not function of Tregs $(165,166)$. Still others 
have found increased Treg percentages in SLE patients (167-169). The discrepancy in data on Treg percentages and function in humans may be due to the fact that human SLE patients present with a wide array of symptoms for which they receive a variety of different treatments that could impact Treg populations. Also, the distinction between active and inactive SLE patients is not made clear in the literature, so different research groups may define them differently and, thus find different results. Another important factor when looking at human Tregs is that activated $\mathrm{CD}^{+} \mathrm{T}$ cells in humans transiently express Foxp3 (138) and some Foxp $3^{+}$cells may actually be the IL-17-producing Foxp $3^{+}$ cells described by Sakaguchi and colleagues (171), so any study defining Tregs as $\mathrm{CD}^{+}{ }^{+} \mathrm{Foxp}^{+}$may also include some activated $\mathrm{T}$ cells. It is, therefore, still not clear whether defects, either quantitative or qualitative, in Tregs in lupus patients are common and whether they play a role in pathogenesis. As more research tools become available, this issue will become clearer. In the meantime, mouse studies are critical to fill in the gaps in our knowledge.

In mice, there has been a great deal of research directed at depleting or increasing Treg populations and determining the impact on disease. As mentioned earlier, Treg depletion using an anti-CD25 monoclonal antibody in BWF1 mice accelerated disease (174). Removal of Tregs through pre-pubertal thymectomy in lupus-prone NZM2328 mice also accelerated disease and mice could be rescued from disease through adoptive transfer of $\mathrm{CD}^{+} \mathrm{CD} 25^{+}$from non-sick mice (175). Increasing Treg populations, whether through adoptive transfer of Tregs or through treatment with tolerizing peptides, could delay or prevent lupus development in lupus-prone mice (176-179). These data together highlight the importance of Tregs in lupus development. 
In our facility, approximately $50 \%$ of female BWF1 mice develop severe kidney disease by 32 weeks of age while $0 \%$ of males have developed disease at this age (Figure 13). Autoantibodies can be detected in the serum of females beginning at about 16 weeks of age and we begin measuring proteinuria in female BWF1 mice at about 28 weeks of age (Figure 24). When we compared Treg populations in sick female, non-sick female, and male 32-36-week-old BWF1 mice, we found that sick females had significantly higher percentages of both $\mathrm{CD} 4{ }^{+} \mathrm{Foxp} 3^{+}$and the $\mathrm{CD} 4^{+} \mathrm{CD} 25^{+} \mathrm{CD} 103^{+}$cells (Figure 15A, 16A). This was surprising because, as stated above, many groups have found that decreased Treg percentages are associated with acceleration and severity of disease and increased Treg percentages are associated with protection from disease. Interestingly, these sick female Tregs, both $\mathrm{CD} 4^{+} \mathrm{CD} 25^{+}$cells and the $\mathrm{CD} 4^{+} \mathrm{CD} 25^{+} \mathrm{CD} 103^{+}$subset, suppressed as well in vitro as non-sick female and male Tregs (Figure 14A, 16D). Morel and colleagues found that $\mathrm{CD} 4^{+} \mathrm{CD} 25^{\circ}$ were resistant to suppression in NZB2410 mice, a congenic mouse model on a C57BL/6 background that expresses the lupus susceptibility locus Sle la (115). However, when we compared $\mathrm{CD} 4^{+} \mathrm{CD} 25^{-}$susceptibility to suppression, we found no differences between sick female, non-sick female, and male susceptibility to suppression in vitro (Figure 14B). Morel and colleagues also found that increased IL- 6 production by bone marrow-derived $\mathrm{DC}$ in vitro rendered $\mathrm{CD} 4^{+} \mathrm{CD} 25^{-}$ responder cells resistant to suppression by $\mathrm{CD} 4^{+} \mathrm{CD} 25^{+}$Tregs (115). However, we found no difference in the ability of APCs to support in vitro suppression between sick females and age-matched non-sick females and males (Figure 14C). Although these data do not rule out the possibility that Tregs in sick female mice function abnormally in vivo, it does 
indicate that neither the Tregs, the $\mathrm{CD} 4^{+} \mathrm{CD} 25^{-}$responders nor the $\mathrm{APC}$ have inherent defects that are detectable in vitro.

It is difficult to determine where in the body Treg suppressive function is needed to control/prevent lupus. Lupus presents with a wide variety of symptoms and immune defects making the identification of the important sites where suppression is needed in vivo very difficult (82). It has been shown, however, that $\mathrm{T}$ cell infiltration into the kidney is absolutely required for development of end-stage kidney disease (91), so the kidney, and particularly the kidney-draining LN, may represent important sites for Treg suppressive function. Thus, we examined the kidney-draining LN to determine whether sick female Tregs were able to traffic to this organ. We found that, as in the periphery, sick females had higher percentages of both $\mathrm{CD} 4^{+} \mathrm{Foxp} 3^{+}$and $\mathrm{CD} 4^{+} \mathrm{CD} 25^{+} \mathrm{CD} 103^{+}$Tregs in kidney-draining LN (Figure 19). We next looked at CD62L expression, since this molecule must be downregulated before T cells can traffic out of the LN. We did not find that sick female Tregs expressed any more CD62L than non-sick female and male Tregs (Figure 20). In the future, it will be necessary to investigate other Treg trafficking molecules (e.g., chemokines) expressed by sick female Tregs in comparison to agematched non-sick females and males.

We could not explain the abundance of Tregs in sick female mice at 32-36 weeks of age, so we decided to investigate Treg populations in BWF1 mice from 9 to 32-36 weeks of age to see how they change with age. As discussed earlier, we found that 9week-old females had lower percentages of both $\mathrm{CD} 4^{+} \mathrm{Foxp}^{+}$and $\mathrm{CD} 4^{+} \mathrm{CD} 25^{+} \mathrm{CD} 103^{+}$ Tregs compared to age-matched males (Figure 9A 10A, 21, 22). By 20 weeks of age, female and male Treg percentages were not significantly different, however female 
percentages still trended lower (Figure 21, 22). At 24-28 weeks of age, female and male BWF1 mice had similar percentages of Tregs, and by 32-36 weeks of age sick females had significantly higher Treg percentages that age-matched non-sick females and males (Figure 15A, 16A, 21, 22). These data suggested that 9 weeks may be an important period in time during which gender differences can influence disease development. Accordingly, we examined female and male 9-week-old mice in greater depth. As discussed previously, 9-week-old female BWF1 mice have decreased percentages of both $\mathrm{CD}^{+} \mathrm{Foxp}^{+}$and $\mathrm{CD}^{+} \mathrm{CD} 25^{+} \mathrm{CD} 103^{+}$Treg subsets when compared to age-matched males (Figure 9A, 10A). These female Tregs suppress as well as male Tregs in vitro, however the $\mathrm{CD}^{+} \mathrm{CD} 25^{-}$effector cells proliferate more in vivo in females than males, suggesting Tregs may be unable to control effector cell proliferation/activation in vivo (Figure 8, 12B). We had found that there were no differences in $\mathrm{CD} 4^{+} \mathrm{CD} 25^{-}$resistance to suppression in vitro between 32-36-week-old sick female, non-sick female, and male mice (Figure 14B). However, there was a possibility that young 9-week-old female $\mathrm{CD} 4^{+} \mathrm{CD} 25^{-}$cells were resistant to suppression at this critical period of time, and for this reason, compared $\mathrm{CD} 4^{+} \mathrm{CD} 25^{-}$resistance to suppression in vitro between 9-week-old females and males. We did not find that female $\mathrm{CD} 4^{+} \mathrm{CD} 25^{-}$responder cells were more resistant to suppression than males, in fact, if anything they were more susceptible to suppression in vitro (Figure 25A). We also found no difference between the ability of 9week-old female and male APCs to support suppression in vitro (Figure 25B). These data suggest that it may be a decreased ratio and not a defect in suppressive function that underlies gender differences in disease susceptibility. 
To add further support to our hypothesis that the pre-disease 9-week-old timepoint is important in setting up gender differences in disease development later on, we depleted $\mathrm{CD} 103^{+}$cells in these young mice. Mice were treated with depleting antibody twice a week from 8-12 weeks of age then given a maintenance dose twice a month from 12-20 weeks of age. We found that CD103-depletion decreased time to disease onset and accelerated death in both female and male BWF 1 mice (Figure 27). These results suggest a role for $\mathrm{CD}_{103^{+}}$cells in protection from disease, as depletion of these cells induced disease in males, and males don't normally develop full-blown disease without castration.

Other immune cells express $\mathrm{CD} 103$ besides the potent $\mathrm{CD} 4^{+} \mathrm{CD} 25^{+} \mathrm{CD} 103^{+}$subset of Tregs. A small percentage of regulatory $\mathrm{CD}^{+}$cells that express $\mathrm{CD} 103$ have been reported $(220,221)$. However, cytotoxic $\mathrm{CD}^{+} \mathrm{T}$ cells express $\mathrm{CD} 103$ as well (222-224). A subset of DCs found primarily in the gut, also expresses CD103 (226). These DCs induce a gut-homing phenotype on T cells (226) and are thought to mediate conversion of $\mathrm{CD} 4^{+} \mathrm{CD} 25^{-}$effector cells to $\mathrm{CD} 4^{+} \mathrm{CD} 25^{+}$Tregs in the gut $(228,229)$. A subset of $\mathrm{CD}_{103}{ }^{+} \mathrm{DCs}$ is also found in the skin (230). A small invariant NKT cell subset found in LN and skin express CD103 and have been found to produce IL-17 (231). We have not yet ruled out the possibility that depletion of any of these cell types may play a role in disease development in our CD103-depleted mice. However, depletion of cytotoxic CD8 ${ }^{+}$ T cells or IL-17-producing NKT cells would presumably reduce inflammation and increase time to disease as well as survival. The $\mathrm{CD} 8^{+} \mathrm{CD} 103^{+}$regulatory $\mathrm{T}$ cells represent a very small percentage and have been reported to play a role in a model of tolerance induced in vivo referred to as anterior chamber-associated immune deviation (ACAID) and it is not clear whether they exist naturally (221). Therefore, we would not 
expect depletion of these cells to have an appreciable impact on disease in BWF1 mice. Depletion of $\mathrm{CD} 11 \mathrm{c}^{+} \mathrm{CD} 103^{+} \mathrm{DCs}$ using anti-CD103 antibody in a model of Bordetella pertussis infection causes decreased inflammatory cellular infiltration in the lung and delayed bacterial clearance (264) suggesting that again, if anything, these DCs are involved in inflammation and not tolerance. This is also true for the prolongation of MHC-mismatched islet allograft survival after depletion of $\mathrm{CD} 103^{+}$cells (265). CD103deficient mice on a C57BL/6 background have reduced $\mathrm{T}$ cell numbers in the gut (217) and develop skin lesions (218), and although they are more susceptible to adoptive transfer of colitis, they do not develop colitis spontaneously (227). Therefore, depletion of $\mathrm{CD} 103^{+} \mathrm{DCs}$ in the gut and skin could potentially cause mice to develop colitis or skin lesions, however, we saw no evidence of either in our CD103-depleted BWF1 mice. Taken together, these data suggest that the majority of immune cells other than Tregs that express CD103 mediate inflammatory rather than tolerogenic responses and it is more likely that their depletion would, therefore, have a positive, rather than the negative effect that we see on prevention of disease. The only tolerogenic $\mathrm{CD}_{103^{+}}$populations appear to reside in the skin and gut, and should have a local and not a systemic effect, and in fact, we did not even see any evidence of a local (no skin or gut lesions) effect in our antiCD103-treated mice. Therefore, we believe that it is depletion of the $\mathrm{CD}^{+} \mathrm{CD} 25^{+} \mathrm{CD} 103^{+}$cells that is affecting disease incidence and mortality in anti-CD103 antibody-treated BWF1 mice.

In summary, these data suggest that the proportion of regulatory $\mathrm{T}$ cells in the peripheral lymphoid organs of mice plays an important role in disease susceptibility very early in the disease process, but not after disease is already established. The data also 
suggest that factors associated with gender play an important role in the development and/or maintenance of the potent $\mathrm{CD} 4^{+} \mathrm{CD} 25^{+} \mathrm{CD} 103^{+}$Treg population in mice, in general, and very likely contribute to the propensity for females to develop autoimmune disease (or the protection of males from disease) through this mechanism. Future work will focus on other potential critical periods of time during disease development and on how altering Treg populations can impact disease. Further investigation will also focus on potential environmental factors and trafficking issues in newly sick female BWF1 mice that could be limiting the effectiveness of their abundant Treg populations and what influence hormones might have on this system. 


\section{REFERENCES}

1. Jacobson, D. L., S. J. Gange, N. R. Rose, and N. M. Graham. 1997. Epidemiology and estimated population burden of selected autoimmune diseases in the United States. Clin Immunol Immunopathol 84:223-243.

2. Grossman, C. J., G. A. Roselle, and C. L. Mendenhall. 1991. Sex steroid regulation of autoimmunity. J Steroid Biochem Mol Biol 40:649-659.

3. Whitacre, C. C., S. C. Reingold, and P. A. O'Looney. 1999. A gender gap in autoimmunity. Science 283:1277-1278.

4. Whitacre, C. C. 2001. Sex differences in autoimmune disease. Nat Immunol 2:777-780.

5. Ackerman, L. S. 2006. Sex hormones and the genesis of autoimmunity. Arch Dermatol 142:371-376.

6. Eidinger, D., and T. J. Garrett. 1972. Studies of the regulatory effects of the sex hormones on antibody formation and stem cell differentiation. $J$ Exp Med 136:1098-1116.

7. Weinstein, Y., S. Ran, and S. Segal. 1984. Sex-associated differences in the regulation of immune responses controlled by the MHC of the mouse. J Immunol 132:656-661.

8. Michaels, R. M., and K. D. Rogers. 1971. A sex difference in immunologic responsiveness. Pediatrics 47:120-123.

9. Amadori, A., R. Zamarchi, G. De Silvestro, G. Forza, G. Cavatton, G. A. Danieli, M. Clementi, and L. Chieco-Bianchi. 1995. Genetic control of the CD4/CD8 Tcell ratio in humans. Nat Med 1:1279-1283.

10. Huygen, K., and K. Palfliet. 1984. Strain variation in interferon gamma production of BCG-sensitized mice challenged with PPD II. Importance of one major autosomal locus and additional sexual influences. Cell Immunol 85:75-81.

11. Gilmore, W., L. P. Weiner, and J. Correale. 1997. Effect of estradiol on cytokine secretion by proteolipid protein-specific $T$ cell clones isolated from multiple sclerosis patients and normal control subjects. J Immunol 158:446-451. 
12. Araneo, B. A., T. Dowell, M. Diegel, and R. A. Daynes. 1991.

Dihydrotestosterone exerts a depressive influence on the production of interleukin-4 (IL-4), IL-5, and gamma-interferon, but not IL-2 by activated murine T cells. Blood 78:688-699.

13. Ahmed, S. A., B. D. Hissong, D. Verthelyi, K. Donner, K. Becker, and E. Karpuzoglu-Sahin. 1999. Gender and risk of autoimmune diseases: possible role of estrogenic compounds. Environ Health Perspect 107 Suppl 5:681-686.

14. Gleicher, N., and D. H. Barad. 2007. Gender as risk factor for autoimmune diseases. $J$ Autoimmun 28:1-6.

15. Beagley, K. W., and C. M. Gockel. 2003. Regulation of innate and adaptive immunity by the female sex hormones oestradiol and progesterone. FEMS Immunol Med Microbiol 38:13-22.

16. Phiel, K. L., R. A. Henderson, S. J. Adelman, and M. M. Elloso. 2005. Differential estrogen receptor gene expression in human peripheral blood mononuclear cell populations. Immunol Lett 97:107-113.

17. Kovats, S., and E. Carreras. 2008. Regulation of dendritic cell differentiation and function by estrogen receptor ligands. Cell Immunol 252:81-90.

18. Igarashi, H., T. Kouro, T. Yokota, P. C. Comp, and P. W. Kincade. 2001. Age and stage dependency of estrogen receptor expression by lymphocyte precursors. Proc Natl Acad Sci U S A 98:15131-15136.

19. Paharkova-Vatchkova, V., R. Maldonado, and S. Kovats. 2004. Estrogen preferentially promotes the differentiation of CD11c+CD11b(intermediate) dendritic cells from bone marrow precursors. J Immunol 172:1426-1436.

20. Venkatesh, J., E. Peeva, X. Xu, and B. Diamond. 2006. Cutting Edge: Hormonal milieu, not antigenic specificity, determines the mature phenotype of autoreactive B cells. J Immunol 176:3311-3314.

21. Ito, A., A. C. Buenafe, A. Matejuk, A. Zamora, M. Silverman, J. Dwyer, A. A Vandenbark, and H. Offner. 2002. Estrogen inhibits systemic T cell expression of TNF-alpha and recruitment of TNF-alpha $(+) \mathrm{T}$ cells and macrophages into the CNS of mice developing experimental encephalomyelitis. Clin Immunol 102:275282.

22. Dulos, G. J., and W. M. Bagchus. 2001. Androgens indirectly accelerate thymocyte apoptosis. Int Immunopharmacol 1:321-328. 
23. Viselli, S. M., S. Stanziale, K. Shults, W. J. Kovacs, and N. J. Olsen. 1995. Castration alters peripheral immune function in normal male mice. Immunology 84:337-342.

24. Ellis, T. M., M. T. Moser, P. T. Le, R. C. Flanigan, and E. D. Kwon. 2001. Alterations in peripheral $\mathrm{B}$ cells and $\mathrm{B}$ cell progenitors following androgen ablation in mice. Int Immunol 13:553-558.

25. Shelat, S. G., F. Aird, and E. Redei. 1997. Exposure to dehydroepiandrosterone in utero affects T-cell function in males only. Neuroimmunomodulation 4:154-162.

26. Spector, T. D., W. Ollier, L. A. Perry, A. J. Silman, P. W. Thompson, and A. Edwards. 1989. Free and serum testosterone levels in 276 males: a comparative study of rheumatoid arthritis, ankylosing spondylitis and healthy controls. Clin Rheumatol 8:37-41.

27. Cutolo, M., A. Sulli, S. Capellino, B. Villaggio, P. Montagna, B. Seriolo, and R. H. Straub. 2004. Sex hormones influence on the immune system: basic and clinical aspects in autoimmunity. Lupus 13:635-638.

28. Macdiarmid, F., D. Wang, L. J. Duncan, A. Purohit, M. W. Ghilchick, and M. J. Reed. 1994. Stimulation of aromatase activity in breast fibroblasts by tumor necrosis factor alpha. Mol Cell Endocrinol 106:17-21.

29. Purohit, A., M. W. Ghilchik, L. Duncan, D. Y. Wang, A. Singh, M. M. Walker, and M. J. Reed. 1995. Aromatase activity and interleukin- 6 production by normal and malignant breast tissues. J Clin Endocrinol Metab 80:3052-3058.

30. Zandman-Goddard, G., E. Peeva, and Y. Shoenfeld. 2007. Gender and autoimmunity. Autoimmun Rev 6:366-372.

31. Dalal, M., S. Kim, and R. R. Voskuhl. 1997. Testosterone therapy ameliorates experimental autoimmune encephalomyelitis and induces a $T$ helper 2 bias in the autoantigen-specific T lymphocyte response. J Immunol 159:3-6.

32. Voskuhl, R. R. 2002. Gender issues and multiple sclerosis. Curr Neurol Neurosci Rep 2:277-286.

33. Voskuhl, R. R., H. Pitchekian-Halabi, A. MacKenzie-Graham, H. F. McFarland, and C. S. Raine. 1996. Gender differences in autoimmune demyelination in the mouse: implications for multiple sclerosis. Ann Neurol 39:724-733.

34. Cua, D. J., D. R. Hinton, and S. A. Stohlman. 1995. Self-antigen-induced Th2 responses in experimental allergic encephalomyelitis (EAE)-resistant mice. Th2mediated suppression of autoimmune disease. $J$ Immunol 155:4052-4059. 
35. Bebo, B. F., Jr., A. A. Vandenbark, and H. Offner. 1996. Male SJL mice do not relapse after induction of EAE with PLP 139-151. J Neurosci Res 45:680-689.

36. Kim, S., and R. R. Voskuhl. 1999. Decreased IL-12 production underlies the decreased ability of male lymph node cells to induce experimental autoimmune encephalomyelitis. J Immunol 162:5561-5568.

37. Gold, S. M., S. Chalifoux, B. S. Giesser, and R. R. Voskuhl. 2008. Immune modulation and increased neurotrophic factor production in multiple sclerosis patients treated with testosterone. J Neuroinflammation 5:32.

38. Makino, S., K. Kunimoto, Y. Muraoka, Y. Mizushima, K. Katagiri, and Y. Tochino. 1980. Breeding of a non-obese, diabetic strain of mice. Jikken Dobutsu 29:1-13.

39. Fox, H. S. 1992. Androgen treatment prevents diabetes in nonobese diabetic mice. $J$ Exp Med 175:1409-1412.

40. Fitzpatrick, F., F. Lepault, F. Homo-Delarche, J. F. Bach, and M. Dardenne. 1991. Influence of castration, alone or combined with thymectomy, on the development of diabetes in the nonobese diabetic mouse. Endocrinology 129:1382-1390.

41. Bao, M., Y. Yang, H. S. Jun, and J. W. Yoon. 2002. Molecular mechanisms for gender differences in susceptibility to T cell-mediated autoimmune diabetes in nonobese diabetic mice. $J$ Immunol 168:5369-5375.

42. Wilder, R. L. 1996. Hormones and autoimmunity: animal models of arthritis. Baillieres Clin Rheumatol 10:259-271.

43. Cutolo, M., and R. L. Wilder. 2000. Different roles for androgens and estrogens in the susceptibility to autoimmune rheumatic diseases. Rheum Dis Clin North Am 26:825-839.

44. Cutolo, M., R. Brizzolara, F. Atzeni, S. Capellino, R. H. Straub, and P. C. Puttini. 2010. The immunomodulatory effects of estrogens: clinical relevance in immunemediated rheumatic diseases. Ann N Y Acad Sci 1193:36-42.

45. Harbuz, M. S., Z. Perveen-Gill, S. L. Lightman, and D. S. Jessop. 1995. A protective role for testosterone in adjuvant-induced arthritis. Br J Rheumatol $34: 1117-1122$.

46. Jansson, L., and R. Holmdahl. 1992. Oestrogen-induced suppression of collagen arthritis; 17 beta-oestradiol is therapeutically active in normal and castrated $\mathrm{F} 1$ hybrid mice of both sexes. Clin Exp Immunol 89:446-451. 
47. Jansson, L., A. Mattsson, R. Mattsson, and R. Holmdahl. 1990. Estrogen induced suppression of collagen arthritis. V: Physiological level of estrogen in DBA/1 mice is therapeutic on established arthritis, suppresses anti-type II collagen T-cell dependent immunity and stimulates polyclonal B-cell activity. $J$ Autoimmun 3:257-270.

48. Holroyd, C. R., and C. J. Edwards. 2009. The effects of hormone replacement therapy on autoimmune disease: rheumatoid arthritis and systemic lupus erythematosus. Climacteric 12:378-386.

49. Lahita, R. G. 1999. The role of sex hormones in systemic lupus erythematosus. Curr Opin Rheumatol 11:352-356.

50. Khan, W. A., M. Uddin, M. W. Khan, and H. S. Chabbra. 2009.

Catecholoestrogens: possible role in systemic lupus erythematosus. Rheumatology (Oxford) 48:1345-1351.

51. Peeva, E., and M. Zouali. 2005. Spotlight on the role of hormonal factors in the emergence of autoreactive B-lymphocytes. Immunol Lett 101:123-143.

52. Shabanova, S. S., L. P. Ananieva, Z. S. Alekberova, and Guzov, II. 2008. Ovarian function and disease activity in patients with systemic lupus erythematosus. Clin Exp Rheumatol 26:436-441.

53. Ruiz-Irastorza, G., F. Lima, J. Alves, M. A. Khamashta, J. Simpson, G. R. Hughes, and N. M. Buchanan. 1996. Increased rate of lupus flare during pregnancy and the puerperium: a prospective study of 78 pregnancies. $\mathrm{Br} J$ Rheumatol 35:133-138.

54. Sanchez-Guerrero, J., M. H. Liang, E. W. Karlson, D. J. Hunter, and G. A. Colditz. 1995. Postmenopausal estrogen therapy and the risk for developing systemic lupus erythematosus. Ann Intern Med 122:430-433.

55. Sanchez-Guerrero, J., E. W. Karlson, M. H. Liang, D. J. Hunter, F. E. Speizer, and G. A. Colditz. 1997. Past use of oral contraceptives and the risk of developing systemic lupus erythematosus. Arthritis Rheum 40:804-808.

56. Meier, C. R., M. C. Sturkenboom, A. S. Cohen, and H. Jick. 1998. Postmenopausal estrogen replacement therapy and the risk of developing systemic lupus erythematosus or discoid lupus. $J$ Rheumatol 25:1515-1519.

57. Mok, C. C., C. S. Lau, and R. W. Wong. 2001. Use of exogenous estrogens in systemic lupus erythematosus. Semin Arthritis Rheum 30:426-435.

58. Petri, M. 2001. Exogenous estrogen in systemic lupus erythematosus: oral contraceptives and hormone replacement therapy. Lupus 10:222-226. 
59. Folomeev, M., M. Dougados, J. Beaune, J. C. Kouyoumdjian, K. Nahoul, B. Amor, and Z. Alekberova. 1992. Plasma sex hormones and aromatase activity in tissues of patients with systemic lupus erythematosus. Lupus 1:191-195.

60. Cavalieri, E., K. Frenkel, J. G. Liehr, E. Rogan, and D. Roy. 2000. Estrogens as endogenous genotoxic agents--DNA adducts and mutations. $J$ Natl Cancer Inst Monogr:75-93.

61. Khan, W. A. 2006. Binding characteristics of SLE anti-DNA autoantibodies to Catecholestrogen-modified DNA. Scand J Immunol 64:677-683.

62. Lahita, R. G., H. L. Bradlow, H. G. Kunkel, and J. Fishman. 1979. Alterations of estrogen metabolism in systemic lupus erythematosus. Arthritis Rheum 22:11951198.

63. Lahita, R. G., H. L. Bradlow, H. G. Kunkel, and J. Fishman. 1981. Increased 16 alpha-hydroxylation of estradiol in systemic lupus erythematosus. $J$ Clin Endocrinol Metab 53:174-178.

64. Lahita, R. G., and H. L. Bradlow. 1987. Klinefelter's syndrome: hormone metabolism in hypogonadal males with systemic lupus erythematosus. $J$ Rheumatol Suppl 14 Suppl 13:154-157.

65. Olsen, N. J., and W. J. Kovacs. 1995. Case report: testosterone treatment of systemic lupus erythematosus in a patient with Klinefelter's syndrome. Am J Med Sci 310:158-160.

66. Helyer, B. J., and J. B. Howie. 1963. Renal disease associated with positive lupus erythematosus tests in a cross-bred strain of mice. Nature 197:197.

67. Lambert, P. H., and F. J. Dixon. 1968. Pathogenesis of the glomerulonephritis of NZB/W mice. $J$ Exp Med 127:507-522.

68. Roubinian, J. R., N. Talal, J. S. Greenspan, J. R. Goodman, and P. K. Siiteri. 1978. Effect of castration and sex hormone treatment on survival, anti-nucleic acid antibodies, and glomerulonephritis in NZB/NZW F1 mice. $J$ Exp Med 147:1568-1583.

69. Keisler, L. W., F. S. vom Saal, D. H. Keisler, P. K. Rudeen, and S. E. Walker. 1995. Aberrant hormone balance in fetal autoimmune NZB/W mice following prenatal exposure to testosterone excess or the androgen blocker flutamide. Biol Reprod 53:1190-1197. 
70. Rider, V., and N. I. Abdou. 2001. Gender differences in autoimmunity: molecular basis for estrogen effects in systemic lupus erythematosus. Int Immunopharmacol 1:1009-1024.

71. Bynote, K. K., J. M. Hackenberg, K. S. Korach, D. B. Lubahn, P. H. Lane, and K. A. Gould. 2008. Estrogen receptor-alpha deficiency attenuates autoimmune disease in (NZB x NZW)F1 mice. Genes Immun 9:137-152.

72. Sthoeger, Z. M., H. Zinger, and E. Mozes. 2003. Beneficial effects of the antioestrogen tamoxifen on systemic lupus erythematosus of (NZBxNZW)F1 female mice are associated with specific reduction of IgG3 autoantibodies. Ann Rheum Dis 62:341-346.

73. Dhaher, Y. Y., B. Greenstein, E. de Fougerolles Nunn, M. Khamashta, and G. R. Hughes. 2000. Strain differences in binding properties of estrogen receptors in immature and adult BALB/c and MRL/MP-lpr/lpr mice, a model of systemic lupus erythematosus. Int J Immunopharmacol 22:247-254.

74. Roa, R., and B. D. Greenstein. 2000. Evidence for pleomorphism of estrogen receptor capacity and affinity in liver and thymus of immature BALB/c and (NZBxNZW) F1 mice, a model of systemic lupus erythematosus. Int $J$ Immunopharmacol 22:897-903.

75. Morel, L. 2007. Genetics of human lupus nephritis. Semin Nephrol 27:2-11.

76. Sebastiani, G. D., and M. Galeazzi. 2009. Immunogenetic studies on systemic lupus erythematosus. Lupus 18:878-883.

77. Hochberg, M. C. 1987. The application of genetic epidemiology to systemic lupus erythematosus. $J$ Rheumatol 14:867-869.

78. Block, S. R., J. B. Winfield, M. D. Lockshin, W. A. D'Angelo, and C. L. Christian. 1975. Studies of twins with systemic lupus erythematosus. A review of the literature and presentation of 12 additional sets. Am J Med 59:533-552.

79. Deapen, D., A. Escalante, L. Weinrib, D. Horwitz, B. Bachman, P. Roy-Burman, A. Walker, and T. M. Mack. 1992. A revised estimate of twin concordance in systemic lupus erythematosus. Arthritis Rheum 35:311-318.

80. Bagavant, H., U. S. Deshmukh, F. Gaskin, and S. M. Fu. 2004. Lupus glomerulonephritis revisited 2004: autoimmunity and end-organ damage. Scand $J$ Immunol 60:52-63.

81. Smolen, J. S., G. Steiner, and M. Aringer. 2005. Anti-cytokine therapy in systemic lupus erythematosus. Lupus 14:189-191. 
82. Eisenberg, R. 2009. Why can't we find a new treatment for SLE? J Autoimmun 32:223-230.

83. Ballok, D. A. 2007. Neuroimmunopathology in a murine model of neuropsychiatric lupus. Brain Res Rev 54:67-79.

84. Sheriff, A., U. S. Gaipl, R. E. Voll, J. R. Kalden, and M. Herrmann. 2004. Apoptosis and systemic lupus erythematosus. Rheum Dis Clin North Am 30:505527, viii-ix.

85. Licht, R., J. W. Dieker, C. W. Jacobs, W. J. Tax, and J. H. Berden. 2004. Decreased phagocytosis of apoptotic cells in diseased SLE mice. J Autoimmun 22:139-145.

86. Trebeden-Negre, H., B. Weill, C. Fournier, and F. Batteux. 2003. B cell apoptosis accelerates the onset of murine lupus. Eur J Immunol 33:1603-1612.

87. Urbonaviciute, V., B. G. Furnrohr, S. Meister, L. Munoz, P. Heyder, F. De Marchis, M. E. Bianchi, C. Kirschning, H. Wagner, A. A. Manfredi, J. R. Kalden, G. Schett, P. Rovere-Querini, M. Herrmann, and R. E. Voll. 2008. Induction of inflammatory and immune responses by HMGB1-nucleosome complexes: implications for the pathogenesis of SLE. J Exp Med 205:3007-3018.

88. Wan, S., Z. Zhou, B. Duan, and L. Morel. 2008. Direct B cell stimulation by dendritic cells in a mouse model of lupus. Arthritis Rheum 58:1741-1750.

89. Ding, D., H. Mehta, W. J. McCune, and M. J. Kaplan. 2006. Aberrant phenotype and function of myeloid dendritic cells in systemic lupus erythematosus. $J$ Immunol 177:5878-5889.

90. Castellano, G., L. A. Trouw, N. Fiore, M. R. Daha, F. P. Schena, and C. van Kooten. 2010. Infiltrating dendritic cells contribute to local synthesis of $\mathrm{Clq}$ in murine and human lupus nephritis. Mol Immunol.

91. Bagavant, H., U. S. Deshmukh, H. Wang, T. Ly, and S. M. Fu. 2006. Role for nephritogenic $\mathrm{T}$ cells in lupus glomerulonephritis: progression to renal failure is accompanied by $\mathrm{T}$ cell activation and expansion in regional lymph nodes. $J$ Immunol 177:8258-8265.

92. Bagavant, H., C. Thompson, K. Ohno, Y. Setiady, and K. S. Tung. 2002. Differential effect of neonatal thymectomy on systemic and organ-specific autoimmune disease. Int Immunol 14:1397-1406.

93. Wofsy, D., J. A. Ledbetter, P. L. Hendler, and W. E. Seaman. 1985. Treatment of murine lupus with monoclonal anti-T cell antibody. $J$ Immunol 134:852-857. 
94. Bloom, R. D., T. O'Connor, B. Cizman, R. Kalluri, A. Naji, and M. P. Madaio. 2002. Intrathymic kidney cells delay the onset of lupus nephritis in MRL-lpr/lpr mice. Int Immunol 14:867-871.

95. Tsuchiya, N., A. Kawasaki, B. P. Tsao, T. Komata, J. M. Grossman, and K. Tokunaga. 2001. Analysis of the association of HLA-DRB1, TNFalpha promoter and TNFR2 (TNFRSF1B) polymorphisms with SLE using transmission disequilibrium test. Genes Immun 2:317-322.

96. Ahearn, J. M., T. T. Provost, C. A. Dorsch, M. B. Stevens, W. B. Bias, and F. C. Arnett. 1982. Interrelationships of HLA-DR, MB, and MT phenotypes, autoantibody expression, and clinical features in systemic lupus erythematosus. Arthritis Rheum 25:1031-1040.

97. Alvarellos, A., J. M. Ahearn, T. T. Provost, C. A. Dorsch, M. B. Stevens, W. B. Bias, and F. C. Arnett. 1983. Relationships of HLA-DR and MT antigens to autoantibody expression in systemic lupus erythematosus. Arthritis Rheum 26:1533-1535.

98. Jacob, C. O., Z. Fronek, G. D. Lewis, M. Koo, J. A. Hansen, and H. O. McDevitt. 1990. Heritable major histocompatibility complex class II-associated differences in production of tumor necrosis factor alpha: relevance to genetic predisposition to systemic lupus erythematosus. Proc Natl Acad Sci U S A 87:1233-1237.

99. Jacob, C. O., and H. O. McDevitt. 1988. Tumour necrosis factor-alpha in murine autoimmune 'lupus' nephritis. Nature 331:356-358.

100. Jacob, C. O., S. K. Lee, and G. Strassmann. 1996. Mutational analysis of TNFalpha gene reveals a regulatory role for the 3 -untranslated region in the genetic predisposition to lupus-like autoimmune disease. J Immunol 156:3043-3050.

101. Charles, P. J., R. J. Smeenk, J. De Jong, M. Feldmann, and R. N. Maini. 2000. Assessment of antibodies to double-stranded DNA induced in rheumatoid arthritis patients following treatment with infliximab, a monoclonal antibody to tumor necrosis factor alpha: findings in open-label and randomized placebo-controlled trials. Arthritis Rheum 43:2383-2390.

102. Duits, A. J., H. Bootsma, R. H. Derksen, P. E. Spronk, L. Kater, C. G. Kallenberg, P. J. Capel, N. A. Westerdaal, G. T. Spierenburg, F. H. Gmelig-Meyling, and et al. 1995. Skewed distribution of IgG Fc receptor IIa (CD32) polymorphism is associated with renal disease in systemic lupus erythematosus patients. Arthritis Rheum 38:1832-1836.

103. Salmon, J. E., S. Millard, L. A. Schachter, F. C. Arnett, E. M. Ginzler, M. F. Gourley, R. Ramsey-Goldman, M. G. Peterson, and R. P. Kimberly. 1996. Fc 
gamma RIIA alleles are heritable risk factors for lupus nephritis in African Americans. J Clin Invest 97:1348-1354.

104. Song, Y. W., C. W. Han, S. W. Kang, H. J. Baek, E. B. Lee, C. H. Shin, B. H. Hahn, and B. P. Tsao. 1998. Abnormal distribution of Fc gamma receptor type Ila polymorphisms in Korean patients with systemic lupus erythematosus. Arthritis Rheum 41:421-426.

105. Wu, J., J. C. Edberg, P. B. Redecha, V. Bansal, P. M. Guyre, K. Coleman, J. E. Salmon, and R. P. Kimberly. 1997. A novel polymorphism of FcgammaRIIIa (CD16) alters receptor function and predisposes to autoimmune disease. $J$ Clin Invest 100:1059-1070.

106. Koene, H. R., M. Kleijer, A. J. Swaak, K. E. Sullivan, M. Bijl, M. A. Petri, C. G. Kallenberg, D. Roos, A. E. von dem Borne, and M. de Haas. 1998. The Fc gammaRIIIA- $158 \mathrm{~F}$ allele is a risk factor for systemic lupus erythematosus. Arthritis Rheum 41:1813-1818.

107. Salmon, J. E., S. Ng, D. H. Yoo, T. H. Kim, S. Y. Kim, and G. G. Song. 1999. Altered distribution of Fcgamma receptor IIIA alleles in a cohort of Korean patients with lupus nephritis. Arthritis Rheum 42:818-819.

108. Salmon, J. E., and L. Pricop. 2001. Human receptors for immunoglobulin G: key elements in the pathogenesis of rheumatic disease. Arthritis Rheum 44:739-750.

109. Chen, Y., C. Cuda, and L. Morel. 2005. Genetic determination of T cell help in loss of tolerance to nuclear antigens. J Immunol 174:7692-7702.

110. Morel, L., K. R. Blenman, B. P. Croker, and E. K. Wakeland. 2001. The major murine systemic lupus erythematosus susceptibility locus, Sle1, is a cluster of functionally related genes. Proc Natl Acad Sci U S A 98:1787-1792.

111. Wandstrat, A. E., C. Nguyen, N. Limaye, A. Y. Chan, S. Subramanian, X. H. Tian, Y. S. Yim, A. Pertsemlidis, H. R. Garner, Jr., L. Morel, and E. K. Wakeland. 2004. Association of extensive polymorphisms in the SLAM/CD2 gene cluster with murine lupus. Immunity 21:769-780.

112. Chen, Y., D. Perry, S. A. Boackle, E. S. Sobel, H. Molina, B. P. Croker, and L. Morel. 2005. Several genes contribute to the production of autoreactive $B$ and $T$ cells in the murine lupus susceptibility locus Sle1c. J Immunol 175:1080-1089.

113. Douglas, K. B., D. C. Windels, J. Zhao, A. V. Gadeliya, H. Wu, K. M. Kaufman, J. B. Harley, J. Merrill, R. P. Kimberly, G. S. Alarcon, E. E. Brown, J. C. Edberg, R. Ramsey-Goldman, M. Petri, J. D. Reveille, L. M. Vila, P. M. Gaffney, J. A. James, K. L. Moser, M. E. Alarcon-Riquelme, T. J. Vyse, G. S. Gilkeson, C. O. Jacob, J. T. Ziegler, C. D. Langefeld, D. Ulgiati, B. P. Tsao, and S. A. Boackle. 
2009. Complement receptor 2 polymorphisms associated with systemic lupus erythematosus modulate alternative splicing. Genes Immun 10:457-469.

114. Wu, H., S. A. Boackle, P. Hanvivadhanakul, D. Ulgiati, J. M. Grossman, Y. Lee, N. Shen, L. J. Abraham, T. R. Mercer, E. Park, L. A. Hebert, B. H. Rovin, D. J. Birmingham, D. M. Chang, C. J. Chen, D. McCurdy, H. M. Badsha, B. Y. Thong, H. H. Chng, F. C. Arnett, D. J. Wallace, C. Y. Yu, B. H. Hahn, R. M. Cantor, and B. P. Tsao. 2007. Association of a common complement receptor 2 haplotype with increased risk of systemic lupus erythematosus. Proc Natl Acad Sci US A 104:3961-3966.

115. Cuda, C. M., S. Wan, E. S. Sobel, B. P. Croker, and L. Morel. 2007. Murine lupus susceptibility locus Sle1a controls regulatory $\mathrm{T}$ cell number and function through multiple mechanisms. J Immunol 179:7439-7447.

116. Wan, S., C. Xia, and L. Morel. 2007. IL-6 produced by dendritic cells from lupusprone mice inhibits CD4+CD25+ T cell regulatory functions. $J$ Immunol 178:271279.

117. Cuda, C. M., L. Zeumer, E. S. Sobel, B. P. Croker, and L. Morel. 2010. Murine lupus susceptibility locus Slela requires the expression of two sub-loci to induce inflammatory T cells. Genes Immun.

118. Hirose, S., R. Nagasawa, I. Sekikawa, M. Hamaoki, Y. Ishida, H. Sato, and T. Shirai. 1983. Enhancing effect of H-2-linked NZW gene(s) on the autoimmune traits of (NZB X NZW)F1 mice. J Exp Med 158:228-233.

119. Theofilopoulos, A. N., and F. J. Dixon. 1985. Murine models of systemic lupus erythematosus. Adv Immunol 37:269-390.

120. Kotzin, B. L., and E. Palmer. 1987. The contribution of NZW genes to lupus-like disease in (NZB x NZW)F1 mice. $J$ Exp Med 165:1237-1251.

121. Sobel, E. S., T. Katagiri, K. Katagiri, S. C. Morris, P. L. Cohen, and R. A. Eisenberg. 1991. An intrinsic B cell defect is required for the production of autoantibodies in the $1 \mathrm{pr}$ model of murine systemic autoimmunity. $J$ Exp Med 173:1441-1449.

122. Rathmell, J. C., and C. C. Goodnow. 1994. Effects of the lpr mutation on elimination and inactivation of self-reactive B cells. $J$ Immunol 153:2831-2842.

123. Sakaguchi, S., T. Yamaguchi, T. Nomura, and M. Ono. 2008. Regulatory T cells and immune tolerance. Cell 133:775-787.

124. Shevach, E. M. 2009. Mechanisms of foxp3+ T regulatory cell-mediated suppression. Immunity 30:636-645. 
125. Sakaguchi, S., N. Sakaguchi, M. Asano, M. Itoh, and M. Toda. 1995.

Immunologic self-tolerance maintained by activated T cells expressing IL-2 receptor alpha-chains (CD25). Breakdown of a single mechanism of self-tolerance causes various autoimmune diseases. $J$ Immunol 155:1151-1164.

126. Fontenot, J. D., J. P. Rasmussen, L. M. Williams, J. L. Dooley, A. G. Farr, and A. Y. Rudensky. 2005. Regulatory T cell lineage specification by the forkhead transcription factor foxp3. Immunity 22:329-341.

127. Fontenot, J. D., M. A. Gavin, and A. Y. Rudensky. 2003. Foxp3 programs the development and function of CD4+CD25+ regulatory T cells. Nat Immunol $4: 330-336$.

128. Coffer, P. J., and B. M. Burgering. 2004. Forkhead-box transcription factors and their role in the immune system. Nat Rev Immunol 4:889-899.

129. Hori, S., T. Nomura, and S. Sakaguchi. 2003. Control of regulatory T cell development by the transcription factor Foxp3. Science 299:1057-1061.

130. Gavin, M. A., J. P. Rasmussen, J. D. Fontenot, V. Vasta, V. C. Manganiello, J. A. Beavo, and A. Y. Rudensky. 2007. Foxp3-dependent programme of regulatory Tcell differentiation. Nature 445:771-775.

131. Hill, J. A., M. Feuerer, K. Tash, S. Haxhinasto, J. Perez, R. Melamed, D. Mathis, and C. Benoist. 2007. Foxp3 transcription-factor-dependent and -independent regulation of the regulatory $\mathrm{T}$ cell transcriptional signature. Immunity 27:786-800.

132. Kim, J. M., J. P. Rasmussen, and A. Y. Rudensky. 2007. Regulatory T cells prevent catastrophic autoimmunity throughout the lifespan of mice. Nat Immunol 8:191-197.

133. Wan, Y. Y., and R. A. Flavell. 2007. Regulatory T-cell functions are subverted and converted owing to attenuated Foxp3 expression. Nature 445:766-770.

134. Williams, L. M., and A. Y. Rudensky. 2007. Maintenance of the Foxp3dependent developmental program in mature regulatory $\mathrm{T}$ cells requires continued expression of Foxp3. Nat Immunol 8:277-284.

135. Bennett, C. L., J. Christie, F. Ramsdell, M. E. Brunkow, P. J. Ferguson, L. Whitesell, T. E. Kelly, F. T. Saulsbury, P. F. Chance, and H. D. Ochs. 2001. The immune dysregulation, polyendocrinopathy, enteropathy, X-linked syndrome (IPEX) is caused by mutations of FOXP3. Nat Genet 27:20-21. 
136. Lahl, K., C. Loddenkemper, C. Drouin, J. Freyer, J. Arnason, G. Eberl, A. Hamann, H. Wagner, J. Huehn, and T. Sparwasser. 2007. Selective depletion of Foxp3+ regulatory T cells induces a scurfy-like disease. $J$ Exp Med 204:57-63.

137. Mantel, P. Y., N. Ouaked, B. Ruckert, C. Karagiannidis, R. Welz, K. Blaser, and C. B. Schmidt-Weber. 2006. Molecular mechanisms underlying FOXP3 induction in human T cells. J Immunol 176:3593-3602.

138. Allan, S. E., S. Q. Crome, N. K. Crellin, L. Passerini, T. S. Steiner, R. Bacchetta, M. G. Roncarolo, and M. K. Levings. 2007. Activation-induced FOXP3 in human $\mathrm{T}$ effector cells does not suppress proliferation or cytokine production. Int Immunol 19:345-354.

139. Baron, U., S. Floess, G. Wieczorek, K. Baumann, A. Grutzkau, J. Dong, A. Thiel, T. J. Boeld, P. Hoffmann, M. Edinger, I. Turbachova, A. Hamann, S. Olek, and J. Huehn. 2007. DNA demethylation in the human FOXP3 locus discriminates regulatory $\mathrm{T}$ cells from activated FOXP3(+) conventional T cells. Eur J Immunol 37:2378-2389.

140. Floess, S., J. Freyer, C. Siewert, U. Baron, S. Olek, J. Polansky, K. Schlawe, H. D. Chang, T. Bopp, E. Schmitt, S. Klein-Hessling, E. Serfling, A. Hamann, and J. Huehn. 2007. Epigenetic control of the foxp3 locus in regulatory T cells. PLoS Biol 5:e38.

141. Kim, H. P., and W. J. Leonard. 2007. CREB/ATF-dependent T cell receptorinduced FoxP3 gene expression: a role for DNA methylation. $J$ Exp Med 204:1543-1551.

142. Tang, Q., J. Y. Adams, A. J. Tooley, M. Bi, B. T. Fife, P. Serra, P. Santamaria, R. M. Locksley, M. F. Krummel, and J. A. Bluestone. 2006. Visualizing regulatory T cell control of autoimmune responses in nonobese diabetic mice. Nat Immunol 7:83-92.

143. Manzotti, C. N., H. Tipping, L. C. Perry, K. I. Mead, P. J. Blair, Y. Zheng, and D. M. Sansom. 2002. Inhibition of human T cell proliferation by CTLA-4 utilizes CD80 and requires CD25+ regulatory T cells. Eur J Immunol 32:2888-2896.

144. Serra, P., A. Amrani, J. Yamanouchi, B. Han, S. Thiessen, T. Utsugi, J. Verdaguer, and P. Santamaria. 2003. CD40 ligation releases immature dendritic cells from the control of regulatory CD4+CD25+ T cells. Immunity 19:877-889.

145. Misra, N., J. Bayry, S. Lacroix-Desmazes, M. D. Kazatchkine, and S. V. Kaveri. 2004. Cutting edge: human $\mathrm{CD} 4+\mathrm{CD} 25+\mathrm{T}$ cells restrain the maturation and antigen-presenting function of dendritic cells. J Immunol 172:4676-4680. 
146. Thornton, A. M., C. A. Piccirillo, and E. M. Shevach. 2004. Activation requirements for the induction of $\mathrm{CD} 4+\mathrm{CD} 25+\mathrm{T}$ cell suppressor function. Eur $J$ Immunol 34:366-376.

147. Wing, K., Y. Onishi, P. Prieto-Martin, T. Yamaguchi, M. Miyara, Z. Fehervari, T. Nomura, and S. Sakaguchi. 2008. CTLA-4 control over Foxp3+ regulatory T cell function. Science 322:271-275.

148. Pasare, C., and R. Medzhitov. 2003. Toll pathway-dependent blockade of CD4+CD25+ T cell-mediated suppression by dendritic cells. Science 299:10331036.

149. McHugh, R. S., M. J. Whitters, C. A. Piccirillo, D. A. Young, E. M. Shevach, M. Collins, and M. C. Byrne. 2002. CD4(+)CD25(+) immunoregulatory T cells: gene expression analysis reveals a functional role for the glucocorticoid-induced TNF receptor. Immunity 16:311-323.

150. Shimizu, J., S. Yamazaki, T. Takahashi, Y. Ishida, and S. Sakaguchi. 2002. Stimulation of CD25(+)CD4(+) regulatory T cells through GITR breaks immunological self-tolerance. Nat Immunol 3:135-142.

151. Kanamaru, F., P. Youngnak, M. Hashiguchi, T. Nishioka, T. Takahashi, S. Sakaguchi, I. Ishikawa, and M. Azuma. 2004. Costimulation via glucocorticoidinduced TNF receptor in both conventional and $\mathrm{CD} 25+$ regulatory $\mathrm{CD} 4+\mathrm{T}$ cells. $J$ Immunol 172:7306-7314.

152. Goleva, E., I. D. Cardona, L. S. Ou, and D. Y. Leung. 2005. Factors that regulate naturally occurring $\mathrm{T}$ regulatory cell-mediated suppression. $J$ Allergy Clin Immunol 116:1094-1100.

153. Andersson, J., I. Stefanova, G. L. Stephens, and E. M. Shevach. 2007. $\mathrm{CD} 4+\mathrm{CD} 25+$ regulatory $\mathrm{T}$ cells are activated in vivo by recognition of self. Int Immunol 19:557-566.

154. Zheng, Y., A. Chaudhry, A. Kas, P. deRoos, J. M. Kim, T. T. Chu, L. Corcoran, P. Treuting, U. Klein, and A. Y. Rudensky. 2009. Regulatory T-cell suppressor program co-opts transcription factor IRF4 to control T(H)2 responses. Nature $458: 351-356$.

155. Zhou, X., L. T. Jeker, B. T. Fife, S. Zhu, M. S. Anderson, M. T. McManus, and J. A. Bluestone. 2008. Selective miRNA disruption in T reg cells leads to uncontrolled autoimmunity. J Exp Med 205:1983-1991.

156. Lu, L. F., T. H. Thai, D. P. Calado, A. Chaudhry, M. Kubo, K. Tanaka, G. B. Loeb, H. Lee, A. Yoshimura, K. Rajewsky, and A. Y. Rudensky. 2009. Foxp3- 
dependent microRNA 155 confers competitive fitness to regulatory $\mathrm{T}$ cells by targeting SOCS1 protein. Immunity 30:80-91.

157. Lim, H. W., P. Hillsamer, and C. H. Kim. 2004. Regulatory T cells can migrate to follicles upon T cell activation and suppress GC-Th cells and GC-Th cell-driven B cell responses. J Clin Invest 114:1640-1649.

158. Lim, H. W., P. Hillsamer, A. H. Banham, and C. H. Kim. 2005. Cutting edge: direct suppression of B cells by $\mathrm{CD} 4+\mathrm{CD} 25+$ regulatory T cells. $J$ Immunol 175:4180-4183.

159. Iikuni, N., E. V. Lourenco, B. H. Hahn, and A. La Cava. 2009. Cutting edge: Regulatory T cells directly suppress B cells in systemic lupus erythematosus. $J$ Immunol 183:1518-1522.

160. La Cava, A. 2008. T-regulatory cells in systemic lupus erythematosus. Lupus $17: 421-425$.

161. Mudd, P. A., B. N. Teague, and A. D. Farris. 2006. Regulatory T cells and systemic lupus erythematosus. Scand J Immunol 64:211-218.

162. Miyara, M., Z. Amoura, C. Parizot, C. Badoual, K. Dorgham, S. Trad, D. Nochy, P. Debre, J. C. Piette, and G. Gorochov. 2005. Global natural regulatory T cell depletion in active systemic lupus erythematosus. $J$ Immunol 175:8392-8400.

163. Lee, J. H., L. C. Wang, Y. T. Lin, Y. H. Yang, D. T. Lin, and B. L. Chiang. 2006. Inverse correlation between $\mathrm{CD} 4+$ regulatory $\mathrm{T}$-cell population and autoantibody levels in paediatric patients with systemic lupus erythematosus. Immunology 117:280-286.

164. Suen, J. L., H. T. Li, Y. J. Jong, B. L. Chiang, and J. H. Yen. 2009. Altered homeostasis of CD4(+) FoxP3(+) regulatory T-cell subpopulations in systemic lupus erythematosus. Immunology 127:196-205.

165. Valencia, X., C. Yarboro, G. Illei, and P. E. Lipsky. 2007. Deficient CD4+CD25high $T$ regulatory cell function in patients with active systemic lupus erythematosus. $J$ Immunol 178:2579-2588.

166. Bonelli, M., A. Savitskaya, K. von Dalwigk, C. W. Steiner, D. Aletaha, J. S. Smolen, and C. Scheinecker. 2008. Quantitative and qualitative deficiencies of regulatory $\mathrm{T}$ cells in patients with systemic lupus erythematosus (SLE). Int Immunol 20:861-868.

167. Bonelli, M., K. von Dalwigk, A. Savitskaya, J. S. Smolen, and C. Scheinecker. 2008. Foxp3 expression in CD4+ T cells of patients with systemic lupus erythematosus: a comparative phenotypic analysis. Ann Rheum Dis 67:664-671. 
168. Zhang, B., X. Zhang, F. Tang, L. Zhu, and Y. Liu. 2008. Reduction of forkhead box $\mathrm{P} 3$ levels in CD4+CD25high $\mathrm{T}$ cells in patients with new-onset systemic lupus erythematosus. Clin Exp Immunol 153:182-187.

169. Azab, N. A., I. H. Bassyouni, Y. Emad, G. A. Abd El-Wahab, G. Hamdy, and M. A. Mashahit. 2008. CD4+CD25+ regulatory T cells (TREG) in systemic lupus erythematosus (SLE) patients: the possible influence of treatment with corticosteroids. Clin Immunol 127:151-157.

170. Barath, S., P. Soltesz, E. Kiss, M. Aleksza, M. Zeher, G. Szegedi, and S. Sipka. 2007. The severity of systemic lupus erythematosus negatively correlates with the increasing number of CD4+CD25(high)FoxP3 + regulatory T cells during repeated plasmapheresis treatments of patients. Autoimmunity 40:521-528.

171. Miyara, M., Y. Yoshioka, A. Kitoh, T. Shima, K. Wing, A. Niwa, C. Parizot, C. Taflin, T. Heike, D. Valeyre, A. Mathian, T. Nakahata, T. Yamaguchi, T. Nomura, M. Ono, Z. Amoura, G. Gorochov, and S. Sakaguchi. 2009. Functional delineation and differentiation dynamics of human $\mathrm{CD} 4+\mathrm{T}$ cells expressing the FoxP3 transcription factor. Immunity 30:899-911.

172. Wu, H. Y., and N. A. Staines. 2004. A deficiency of CD4+CD25+ T cells permits the development of spontaneous lupus-like disease in mice, and can be reversed by induction of mucosal tolerance to histone peptide autoantigen. Lupus 13:192200.

173. Hsu, W. T., J. L. Suen, and B. L. Chiang. 2006. The role of CD4CD25 T cells in autoantibody production in murine lupus. Clin Exp Immunol 145:513-519.

174. Hayashi, T., K. Hasegawa, and C. Adachi. 2005. Elimination of CD4(+)CD25(+) $T$ cell accelerates the development of glomerulonephritis during the preactive phase in autoimmune-prone female NZB x NZW F mice. Int J Exp Pathol $86: 289-296$.

175. Bagavant, H., and K. S. Tung. 2005. Failure of CD25+ T cells from lupus-prone mice to suppress lupus glomerulonephritis and sialoadenitis. J Immunol 175:944950.

176. Kang, H. K., M. A. Michaels, B. R. Berner, and S. K. Datta. 2005. Very low-dose tolerance with nucleosomal peptides controls lupus and induces potent regulatory T cell subsets. J Immunol 174:3247-3255.

177. Sharabi, A., H. Zinger, M. Zborowsky, Z. M. Sthoeger, and E. Mozes. 2006. A peptide based on the complementarity-determining region 1 of an autoantibody ameliorates lupus by up-regulating CD4+CD25+ cells and TGF-beta. Proc Natl Acad Sci U S A 103:8810-8815. 
178. Scalapino, K. J., Q. Tang, J. A. Bluestone, M. L. Bonyhadi, and D. I. Daikh. 2006. Suppression of disease in New Zealand Black/New Zealand White lupusprone mice by adoptive transfer of ex vivo expanded regulatory T cells. $J$ Immunol 177:1451-1459.

179. Scalapino, K. J., and D. I. Daikh. 2009. Suppression of glomerulonephritis in NZB/NZW lupus prone mice by adoptive transfer of ex vivo expanded regulatory T cells. PLoS One 4:e6031.

180. Yan, B., S. Ye, G. Chen, M. Kuang, N. Shen, and S. Chen. 2008. Dysfunctional $\mathrm{CD} 4+, \mathrm{CD} 25+$ regulatory $\mathrm{T}$ cells in untreated active systemic lupus erythematosus secondary to interferon-alpha-producing antigen-presenting cells. Arthritis Rheum $58: 801-812$.

181. Tang, Q., J. Y. Adams, C. Penaranda, K. Melli, E. Piaggio, E. Sgouroudis, C. A. Piccirillo, B. L. Salomon, and J. A. Bluestone. 2008. Central role of defective interleukin-2 production in the triggering of islet autoimmune destruction. Immunity 28:687-697.

182. Venken, K., N. Hellings, M. Thewissen, V. Somers, K. Hensen, J. L. Rummens, R. Medaer, R. Hupperts, and P. Stinissen. 2008. Compromised CD4+ CD25(high) regulatory $\mathrm{T}$-cell function in patients with relapsing-remitting multiple sclerosis is correlated with a reduced frequency of FOXP3-positive cells and reduced FOXP3 expression at the single-cell level. Immunology 123:79-89.

183. Kohm, A. P., P. A. Carpentier, H. A. Anger, and S. D. Miller. 2002. Cutting edge: CD4+CD25+ regulatory $T$ cells suppress antigen-specific autoreactive immune responses and central nervous system inflammation during active experimental autoimmune encephalomyelitis. J Immunol 169:4712-4716.

184. Makita, S., T. Kanai, Y. Nemoto, T. Totsuka, R. Okamoto, K. Tsuchiya, M. Yamamoto, H. Kiyono, and M. Watanabe. 2007. Intestinal lamina propria retaining $\mathrm{CD} 4+\mathrm{CD} 25+$ regulatory $\mathrm{T}$ cells is a suppressive site of intestinal inflammation. J Immunol 178:4937-4946.

185. Jordan, M. S., A. Boesteanu, A. J. Reed, A. L. Petrone, A. E. Holenbeck, M. A. Lerman, A. Naji, and A. J. Caton. 2001. Thymic selection of CD4+CD25+ regulatory T cells induced by an agonist self-peptide. Nat Immunol 2:301-306.

186. Liu, Y., P. Zhang, J. Li, A. B. Kulkarni, S. Perruche, and W. Chen. 2008. A critical function for TGF-beta signaling in the development of natural CD4+CD25+Foxp3+ regulatory T cells. Nat Immunol 9:632-640.

187. Pacholczyk, R., H. Ignatowicz, P. Kraj, and L. Ignatowicz. 2006. Origin and T cell receptor diversity of Foxp3+CD4+CD25+ T cells. Immunity 25:249-259. 
188. Bochtler, P., C. Wahl, R. Schirmbeck, and J. Reimann. 2006. Functional adaptive CD4 Foxp3 T cells develop in MHC class II-deficient mice. J Immunol 177:83078314.

189. Stephens, G. L., J. Andersson, and E. M. Shevach. 2007. Distinct subsets of FoxP $3+$ regulatory $\mathrm{T}$ cells participate in the control of immune responses. $J$ Immunol 178:6901-6911.

190. Chen, W., W. Jin, N. Hardegen, K. J. Lei, L. Li, N. Marinos, G. McGrady, and S. M. Wahl. 2003. Conversion of peripheral CD4+CD25- naive T cells to CD4+CD25+ regulatory T cells by TGF-beta induction of transcription factor Foxp3. J Exp Med 198:1875-1886.

191. Liang, S., P. Alard, Y. Zhao, S. Parnell, S. L. Clark, and M. M. Kosịewicz. 2005. Conversion of CD4+ CD25- cells into CD4+ CD25+ regulatory T cells in vivo requires B7 costimulation, but not the thymus. $J \operatorname{Exp}$ Med 201:127-137.

192. Huter, E. N., G. A. Punkosdy, D. D. Glass, L. I. Cheng, J. M. Ward, and E. M. Shevach. 2008. TGF-beta-induced Foxp3+ regulatory T cells rescue scurfy mice. Eur J Immunol 38:1814-1821.

193. Thornton, A. M., and E. M. Shevach. 2000. Suppressor effector function of $\mathrm{CD} 4+\mathrm{CD} 25+$ immunoregulatory $\mathrm{T}$ cells is antigen nonspecific. $J$ Immunol 164:183-190.

194. Bluestone, J. A., and Q. Tang. 2004. Therapeutic vaccination using CD4+CD25+ antigen-specific regulatory T cells. Proc Natl Acad Sci U S A 101 Suppl 2:1462214626.

195. Tang, Q., K. J. Henriksen, M. Bi, E. B. Finger, G. Szot, J. Ye, E. L. Masteller, H. McDevitt, M. Bonyhadi, and J. A. Bluestone. 2004. In vitro-expanded antigenspecific regulatory T cells suppress autoimmune diabetes. J Exp Med 199:14551465.

196. Tarbell, K. V., S. Yamazaki, K. Olson, P. Toy, and R. M. Steinman. 2004. CD25+ CD4+ T cells, expanded with dendritic cells presenting a single autoantigenic peptide, suppress autoimmune diabetes. J Exp Med 199:1467-1477.

197. Masteller, E. L., M. R. Warner, Q. Tang, K. V. Tarbell, H. McDevitt, and J. A. Bluestone. 2005. Expansion of functional endogenous antigen-specific $\mathrm{CD} 4+\mathrm{CD} 25+$ regulatory $\mathrm{T}$ cells from nonobese diabetic mice. $J$ Immunol 175:3053-3059.

198. Shaw, S. K., K. L. Cepek, E. A. Murphy, G. J. Russell, M. B. Brenner, and C. M. Parker. 1994. Molecular cloning of the human mucosal lymphocyte integrin alpha 
E subunit. Unusual structure and restricted RNA distribution. $J$ Biol Chem 269:6016-6025.

199. Cepek, K. L., C. M. Parker, J. L. Madara, and M. B. Brenner. 1993. Integrin alpha E beta 7 mediates adhesion of T lymphocytes to epithelial cells. J Immunol 150:3459-3470.

200. Cepek, K. L., S. K. Shaw, C. M. Parker, G. J. Russell, J. S. Morrow, D. L. Rimm, and M. B. Brenner. 1994. Adhesion between epithelial cells and T lymphocytes mediated by E-cadherin and the alpha E beta 7 integrin. Nature 372:190-193.

201. Higgins, J. M., D. A. Mandlebrot, S. K. Shaw, G. J. Russell, E. A. Murphy, Y. T. Chen, W. J. Nelson, C. M. Parker, and M. B. Brenner. 1998. Direct and regulated interaction of integrin alphaEbeta7 with E-cadherin. J Cell Biol 140:197-210.

202. Kutlesa, S., J. T. Wessels, A. Speiser, I. Steiert, C. A. Muller, and G. Klein. 2002. E-cadherin-mediated interactions of thymic epithelial cells with CD103+ thymocytes lead to enhanced thymocyte cell proliferation. J Cell Sci 115:45054515 .

203. McCaughtry, T. M., M. S. Wilken, and K. A. Hogquist. 2007. Thymic emigration revisited. $J$ Exp Med 204:2513-2520.

204. Demetter, P., D. Baeten, F. De Keyser, M. De Vos, N. Van Damme, G. Verbruggen, S. Vermeulen, M. Mareel, D. Elewaut, H. Mielants, E. M. Veys, and C. A. Cuvelier. 2000. Subclinical gut inflammation in spondyloarthropathy patients is associated with upregulation of the E-cadherin/catenin complex. Ann Rheum Dis 59:211-216.

205. Strauch, U. G., R. C. Mueller, X. Y. Li, M. Cernadas, J. M. Higgins, D. G. Binion, and C. M. Parker. 2001. Integrin alpha E(CD103)beta 7 mediates adhesion to intestinal microvascular endothelial cell lines via an E-cadherinindependent interaction. $J$ Immunol 166:3506-3514.

206. Brown, D. W., J. Furness, P. M. Speight, G. J. Thomas, J. Li, M. H. Thornhill, and P. M. Farthing. 1999. Mechanisms of binding of cutaneous lymphocyteassociated antigen-positive and alphaebeta7-positive lymphocytes to oral and skin keratinocytes. Immunology 98:9-15.

207. Lehmann, J., J. Huehn, M. de la Rosa, F. Maszyna, U. Kretschmer, V. Krenn, M. Brunner, A. Scheffold, and A. Hamann. 2002. Expression of the integrin alpha Ebeta 7 identifies unique subsets of $\mathrm{CD} 25+$ as well as CD25- regulatory T cells. Proc Natl Acad Sci U S A 99:13031-13036. 
208. Allakhverdi, Z., D. Fitzpatrick, A. Boisvert, N. Baba, S. Bouguermouh, M. Sarfati, and G. Delespesse. 2006. Expression of CD103 identifies human regulatory T-cell subsets. $J$ Allergy Clin Immunol 118:1342-1349.

209. Rotzschke, O., G. Borsellino, L. Battistini, K. Falk, and M. Kleinewietfeld. 2009. In vivo-activated CD103+ Foxp3+ Tregs: of men and mice. Blood 113:21192120; author reply 2120 .

210. Huehn, J., K. Siegmund, J. C. Lehmann, C. Siewert, U. Haubold, M. Feuerer, G. F. Debes, J. Lauber, O. Frey, G. K. Przybylski, U. Niesner, M. de la Rosa, C. A. Schmidt, R. Brauer, J. Buer, A. Scheffold, and A. Hamann. 2004. Developmental stage, phenotype, and migration distinguish naive- and effector/memory-like CD4+ regulatory T cells. J Exp Med 199:303-313.

211. Banz, A., A. Peixoto, C. Pontoux, C. Cordier, B. Rocha, and M. Papiernik. 2003. A unique subpopulation of CD4+ regulatory $\mathrm{T}$ cells controls wasting disease, IL10 secretion and T cell homeostasis. Eur J Immunol 33:2419-2428.

212. Suffia, I., S. K. Reckling, G. Salay, and Y. Belkaid. 2005. A role for CD103 in the retention of CD4+CD25+ Treg and control of Leishmania major infection. $J$ Immunol 174:5444-5455.

213. Siegmund, K., M. Feuerer, C. Siewert, S. Ghani, U. Haubold, A. Dankof, V. Krenn, M. P. Schon, A. Scheffold, J. B. Lowe, A. Hamann, U. Syrbe, and J. Huehn. 2005. Migration matters: regulatory T-cell compartmentalization determines suppressive activity in vivo. Blood 106:3097-3104.

214. Butcher, E. C., and L. J. Picker. 1996. Lymphocyte homing and homeostasis. Science 272:60-66.

215. Schlickum, S., H. Sennefelder, M. Friedrich, G. Harms, M. J. Lohse, P. Kilshaw, and M. P. Schon. 2008. Integrin alpha E(CD103)beta 7 influences cellular shape and motility in a ligand-dependent fashion. Blood 112:619-625.

216. Sather, B. D., P. Treuting, N. Perdue, M. Miazgowicz, J. D. Fontenot, A. Y. Rudensky, and D. J. Campbell. 2007. Altering the distribution of Foxp3(+) regulatory $\mathrm{T}$ cells results in tissue-specific inflammatory disease. $J$ Exp Med 204:1335-1347.

217. Schon, M. P., A. Arya, E. A. Murphy, C. M. Adams, U. G. Strauch, W. W. Agace, J. Marsal, J. P. Donohue, H. Her, D. R. Beier, S. Olson, L. Lefrancois, M. B. Brenner, M. J. Grusby, and C. M. Parker. 1999. Mucosal T lymphocyte numbers are selectively reduced in integrin alpha $\mathrm{E}$ (CD103)-deficient mice. $J$ Immunol 162:6641-6649. 
218. Schon, M. P., M. Schon, H. B. Warren, J. P. Donohue, and C. M. Parker. 2000. Cutaneous inflammatory disorder in integrin alphaE (CD103)-deficient mice. $J$ Immunol 165:6583-6589.

219. Zhao, D., C. Zhang, T. Yi, C. L. Lin, I. Todorov, F. Kandeel, S. Forman, and D. Zeng. 2008. In vivo-activated $\mathrm{CD} 103+\mathrm{CD} 4+$ regulatory $\mathrm{T}$ cells ameliorate ongoing chronic graft-versus-host disease. Blood 112:2129-2138.

220. Uss, E., A. T. Rowshani, B. Hooibrink, N. M. Lardy, R. A. van Lier, and I. J. ten Berge. 2006. CD103 is a marker for alloantigen-induced regulatory CD8+ T cells. $J$ Immunol 177:2775-2783.

221. Keino, H., S. Masli, S. Sasaki, J. W. Streilein, and J. Stein-Streilein. 2006. CD8+ $T$ regulatory cells use a novel genetic program that includes CD103 to suppress Th1 immunity in eye-derived tolerance. Invest Ophthalmol Vis Sci 47:1533-1542.

222. Fujihara, T., H. Fujita, K. Tsubota, K. Saito, K. Tsuzaka, T. Abe, and T. Takeuchi. 1999. Preferential localization of CD8+ alpha E beta 7+ T cells around acinar epithelial cells with apoptosis in patients with Sjogren's syndrome. $J$ Immunol 163:2226-2235.

223. Masson, F., T. Calzascia, W. Di Berardino-Besson, N. de Tribolet, P. Y. Dietrich, and P. R. Walker. 2007. Brain microenvironment promotes the final functional maturation of tumor-specific effector CD8 + T cells. J Immunol 179:845-853.

224. Smyth, L. J., J. A. Kirby, and A. C. Cunningham. 2007. Role of the mucosal integrin alpha(E)(CD103)beta(7) in tissue-restricted cytotoxicity. Clin Exp Immunol 149:162-170.

225. Grueter, B., M. Petter, T. Egawa, K. Laule-Kilian, C. J. Aldrian, A. Wuerch, Y. Ludwig, H. Fukuyama, H. Wardemann, R. Waldschuetz, T. Moroy, I. Taniuchi, V. Steimle, D. R. Littman, and M. Ehlers. 2005. Runx3 regulates integrin alpha E/CD103 and CD4 expression during development of CD4-/CD8+ T cells. $J$ Immunol 175:1694-1705.

226. Johansson-Lindbom, B., M. Svensson, O. Pabst, C. Palmqvist, G. Marquez, R. Forster, and W. W. Agace. 2005. Functional specialization of gut CD103+ dendritic cells in the regulation of tissue-selective T cell homing. $J$ Exp Med 202:1063-1073.

227. Annacker, O., J. L. Coombes, V. Malmstrom, H. H. Uhlig, T. Bourne, B. Johansson-Lindbom, W. W. Agace, C. M. Parker, and F. Powrie. 2005. Essential role for CD103 in the T cell-mediated regulation of experimental colitis. $J$ Exp Med 202:1051-1061. 
228. Sun, C. M., J. A. Hall, R. B. Blank, N. Bouladoux, M. Oukka, J. R. Mora, and Y. Belkaid. 2007. Small intestine lamina propria dendritic cells promote de novo generation of Foxp3 T reg cells via retinoic acid. $J$ Exp Med 204:1775-1785.

229. Coombes, J. L., K. R. Siddiqui, C. V. Arancibia-Carcamo, J. Hall, C. M. Sun, Y. Belkaid, and F. Powrie. 2007. A functionally specialized population of mucosal CD103+ DCs induces Foxp3+ regulatory T cells via a TGF-beta and retinoic acid-dependent mechanism. $J$ Exp Med 204:1757-1764.

230. Bedoui, S., P. G. Whitney, J. Waithman, L. Eidsmo, L. Wakim, I. Caminschi, R. S. Allan, M. Wojtasiak, K. Shortman, F. R. Carbone, A. G. Brooks, and W. R. Heath. 2009. Cross-presentation of viral and self antigens by skin-derived CD103+ dendritic cells. Nat Immunol 10:488-495.

231. Doisne, J. M., C. Becourt, L. Amniai, N. Duarte, J. B. Le Luduec, G. Eberl, and K. Benlagha. 2009. Skin and peripheral lymph node invariant NKT cells are mainly retinoic acid receptor-related orphan receptor (gamma)t + and respond preferentially under inflammatory conditions. J Immunol 183:2142-2149.

232. Smith, T. J., L. A. Ducharme, S. K. Shaw, C. M. Parker, M. B. Brenner, P. J. Kilshaw, and J. H. Weis. 1994. Murine M290 integrin expression modulated by mast cell activation. Immunity 1:393-403.

233. Robinson, P. W., S. J. Green, C. Carter, J. Coadwell, and P. J. Kilshaw. 2001. Studies on transcriptional regulation of the mucosal T-cell integrin alphaEbeta7 (CD103). Immunology 103:146-154.

234. Sarfati, M., G. Fortin, M. Raymond, and S. Susin. 2008. CD47 in the immune response: role of thrombospondin and SIRP-alpha reverse signaling. Curr Drug Targets 9:842-850.

235. Van, V. Q., J. Darwiche, M. Raymond, S. Lesage, S. Bouguermouh, M. Rubio, and M. Sarfati. 2008. Cutting edge: CD47 controls the in vivo proliferation and homeostasis of peripheral CD4+CD25+ Foxp $3+$ regulatory T cells that express CD103. J Immunol 181:5204-5208.

236. Singh, R. R., F. M. Ebling, D. A. Albuquerque, V. Saxena, V. Kumar, E. H. Giannini, T. N. Marion, F. D. Finkelman, and B. H. Hahn. 2002. Induction of autoantibody production is limited in nonautoimmune mice. J Immunol 169:587594.

237. Sekiguchi, D. R., L. Yunk, D. Gary, D. Charan, B. Srivastava, D. Allman, M. G. Weigert, and E. T. Prak. 2006. Development and selection of edited B cells in B6.56R mice. J Immunol 176:6879-6887. 
238. Wu, J., J. Marler, N. I. Lenchik, and I. C. Gerling. 2006. Strain differences in allele and expression levels of CD72 on B-lymphocytes from NOD, AKR, NON and C57BL/6 mice. Immunol Lett 103:115-120.

239. Hazlett, L. D., S. McClellan, B. Kwon, and R. Barrett. 2000. Increased severity of Pseudomonas aeruginosa corneal infection in strains of mice designated as Th1 versus Th2 responsive. Invest Ophthalmol Vis Sci 41:805-810.

240. Lundberg, P., H. Openshaw, M. Wang, H. J. Yang, and E. Cantin. 2007. Effects of CXCR3 signaling on development of fatal encephalitis and corneal and periocular skin disease in HSV-infected mice are mouse-strain dependent. Invest Ophthalmol Vis Sci 48:4162-4170.

241. Roque, S., C. Nobrega, R. Appelberg, and M. Correia-Neves. 2007. IL-10 underlies distinct susceptibility of BALB/c and C57BL/6 mice to Mycobacterium avium infection and influences efficacy of antibiotic therapy. J Immunol 178:8028-8035.

242. Sun, B., L. V. Rizzo, S. H. Sun, C. C. Chan, B. Wiggert, R. L. Wilder, and R. R. Caspi. 1997. Genetic susceptibility to experimental autoimmune uveitis involves more than a predisposition to generate a T helper-1-like or a T helper-2-like response. J Immunol 159:1004-1011.

243. Silver, P. B., C. C. Chan, B. Wiggert, and R. R. Caspi. 1999. The requirement for pertussis to induce EAU is strain-dependent: B10.RIII, but not B10.A mice, develop EAU and Th1 responses to IRBP without pertussis treatment. Invest Ophthalmol Vis Sci 40:2898-2905.

244. Berzins, S. P., E. S. Venanzi, C. Benoist, and D. Mathis. 2003. T-cell compartments of prediabetic NOD mice. Diabetes 52:327-334.

245. Smith-Bouvier, D. L., A. A. Divekar, M. Sasidhar, S. Du, S. K. Tiwari-Woodruff, J. K. King, A. P. Arnold, R. R. Singh, and R. R. Voskuhl. 2008. A role for sex chromosome complement in the female bias in autoimmune disease. $J$ Exp Med 205:1099-1108.

246. deLuca, L. E., N. B. Pikor, J. O'Leary, G. Galicia-Rosas, L. A. Ward, D. Defreitas, T. M. Finlay, S. S. Ousman, L. R. Osborne, and J. L. Gommerman. 2010. Substrain differences reveal novel disease-modifying gene candidates that alter the clinical course of a rodent model of multiple sclerosis. J Immunol 184:3174-3185.

247. Nagayama, Y., M. Kita-Furuyama, T. Ando, K. Nakao, H. Mizuguchi, T. Hayakawa, K. Eguchi, and M. Niwa. 2002. A novel murine model of Graves' hyperthyroidism with intramuscular injection of adenovirus expressing the thyrotropin receptor. J Immunol 168:2789-2794. 
248. Nagayama, Y., S. M. McLachlan, B. Rapoport, and M. Niwa. 2003. A major role for non-major histocompatibility complex genes but not for microorganisms in a novel murine model of Graves' hyperthyroidism. Thyroid 13:233-238.

249. Chen, C. R., H. Aliesky, P. N. Pichurin, Y. Nagayama, S. M. McLachlan, and B. Rapoport. 2004. Susceptibility rather than resistance to hyperthyroidism is dominant in a thyrotropin receptor adenovirus-induced animal model of Graves' disease as revealed by BALB/c-C57BL/6 hybrid mice. Endocrinology 145:49274933.

250. Seetharamaiah, G. S., and K. J. Land. 2006. Differential Susceptibility of BALB/c and BALB/cBy mice to Graves' hyperthyroidism. Thyroid 16:651-658.

251. Rapoport, B., R. W. Williams, C. R. Chen, and S. M. McLachlan. 2010. Immunoglobulin heavy chain variable region genes contribute to the induction of thyroid-stimulating antibodies in recombinant inbred mice. Genes Immun 11:254263.

252. Bolland, S., and J. V. Ravetch. 2000. Spontaneous autoimmune disease in $\mathrm{Fc}$ (gamma)RIIB-deficient mice results from strain-specific epistasis. Immunity 13:277-285.

253. Tarasenko, T., H. K. Kole, and S. Bolland. 2008. A lupus-suppressor BALB/c locus restricts $\mathrm{IgG} 2$ autoantibodies without altering intrinsic B cell-tolerance mechanisms. J Immunol 180:3807-3814.

254. Chen, X., J. J. Oppenheim, and O. M. Howard. 2005. BALB/c mice have more $\mathrm{CD} 4+\mathrm{CD} 25+\mathrm{T}$ regulatory cells and show greater susceptibility to suppression of their CD4+CD25- responder T cells than C57BL/6 mice. J Leukoc Biol 78:114121.

255. Siemasko, K. F., J. Gao, V. L. Calder, R. Hanna, M. Calonge, S. C. Pflugfelder, J. Y. Niederkorn, and M. E. Stern. 2008. In vitro expanded CD4+CD25+Foxp3+ regulatory $\mathrm{T}$ cells maintain a normal phenotype and suppress immune-mediated ocular surface inflammation. Invest Ophthalmol Vis Sci 49:5434-5440.

256. Ferreira, C., Y. Singh, A. L. Furmanski, F. S. Wong, O. A. Garden, and J. Dyson. 2009. Non-obese diabetic mice select a low-diversity repertoire of natural regulatory T cells. Proc Natl Acad Sci US A 106:8320-8325.

257. Gavin, M. A., S. R. Clarke, E. Negrou, A. Gallegos, and A. Rudensky. 2002. Homeostasis and anergy of CD4(+)CD25(+) suppressor T cells in vivo. Nat Immunol 3:33-41. 
258. McFarland, R. D., D. C. Douek, R. A. Koup, and L. J. Picker. 2000. Identification of a human recent thymic emigrant phenotype. Proc Natl Acad Sci US A 97:4215-4220.

259. Hale, J. S., and P. J. Fink. 2009. Back to the thymus: peripheral T cells come home. Immunol Cell Biol 87:58-64.

260. Irjala, H., E. L. Johansson, R. Grenman, K. Alanen, M. Salmi, and S. Jalkanen. 2001. Mannose receptor is a novel ligand for L-selectin and mediates lymphocyte binding to lymphatic endothelium. $J$ Exp Med 194:1033-1042.

261. Okuda, Y., M. Okuda, and C. C. Bernard. 2002. Gender does not influence the susceptibility of C57BL/6 mice to develop chronic experimental autoimmune encephalomyelitis induced by myelin oligodendrocyte glycoprotein. Immunol Lett 81:25-29.

262. Farkas, B., F. Boldizsar, O. Tarjanyi, A. Laszlo, S. M. Lin, G. Hutas, B. Tryniszewska, A. Mangold, G. Nagyeri, H. L. Rosenzweig, A. Finnegan, K. Mikecz, and T. T. Glant. 2009. BALB/c mice genetically susceptible to proteoglycan-induced arthritis and spondylitis show colony-dependent differences in disease penetrance. Arthritis Res Ther 11:R21.

263. Reddy, J., Z. Illes, X. Zhang, J. Encinas, J. Pyrdol, L. Nicholson, R. A. Sobel, K. W. Wucherpfennig, and V. K. Kuchroo. 2004. Myelin proteolipid protein-specific $\mathrm{CD} 4+\mathrm{CD} 25+$ regulatory cells mediate genetic resistance to experimental autoimmune encephalomyelitis. Proc Natl Acad Sci U S A 101:15434-15439.

264. Dunne, P. J., B. Moran, R. C. Cummins, and K. H. Mills. 2009. CD11c+CD8alpha+ dendritic cells promote protective immunity to respiratory infection with Bordetella pertussis. J Immunol 183:400-410.

265. Zhang, L., S. D. Moffatt-Bruce, A. A. Gaughan, J. J. Wang, A. Rajab, and G. A. Hadley. 2009. An anti-CD103 immunotoxin promotes long-term survival of pancreatic islet allografts. Am J Transplant 9:2012-2023. 


\section{LIST OF ABBREVIATIONS}

\begin{tabular}{|c|c|}
\hline ACAID & Anterior Chamber-Associated Immune Deviation \\
\hline APC & Antigen Presenting Cell \\
\hline $\mathrm{BCG}$ & Bacillus Calmette-Guérin \\
\hline BWF1 & $(\mathrm{NZBxNZW}) \mathrm{F} 1$ \\
\hline $\mathrm{CNS}$ & Central Nervous System \\
\hline $\mathrm{Cr} 2$ & Complement receptor 2 \\
\hline CTLA-4 & Cytotoxic T-Lymphocyte-Associated Protein 4 \\
\hline DC & Dendritic Cell \\
\hline DHEA & Dehydroepiandrosterone \\
\hline DHT & Dihydrotestosterone \\
\hline DNA & Deoxyribonucleic Acid \\
\hline dsDNA & double-stranded Deoxyribonucleic Acid \\
\hline DTH & Delayed-Type Hypersensitivity \\
\hline EAE & Experimental Autoimmune Encephalomyelitis \\
\hline EAU & Experimental Autoimmune Uveitis \\
\hline ER & Estrogen Receptor \\
\hline $\mathrm{Fc} \gamma \mathrm{R}$ & Fc-gamma Receptor \\
\hline GITR & Glucocorticoid-Induced TNFR-Related Protein \\
\hline
\end{tabular}




$\begin{array}{ll}\text { GVHD } & \text { Graft-Versus-Host Disease } \\ \text { HLA } & \text { Human Leukocyte Antigen } \\ \text { HMGB1 } & \text { High-Mobility Group Box 1 } \\ \text { ICOS } & \text { Inducible Costimulatory Molecule } \\ \text { IFN } & \text { Interferon } \\ \text { Ig } & \text { Immunoglobulin } \\ \text { IL } & \text { Interleukin } \\ \text { IPEX } & \text { Immunodysregulation Polyendocrinopathy Enteropathy X-linked } \\ \text { IRF4 } & \text { Syndrome } \\ \text { Kid-LN } & \text { Kidney-draining LN } \\ \text { MBP } & \text { Myelin Basic Protein } \\ \text { MHC } & \text { Major Histocompatibility Complex } \\ \text { mRNA } & \text { Messenger Ribonucleic Acid } \\ \text { MS } & \text { Multiple Sclerosis } \\ \text { Naip1 } & \text { NLR Family Apoptosis Inhibitory Protein 1 } \\ \text { NOD } & \text { Non-Obese Diabetic } \\ \text { Pbx1 } & \text { Pre-B-cell Leukemia Homeobox 1 } \\ \text { PPD } & \text { Purified Protein Derivative } \\ \text { RA } & \text { Rheumatoid Arthritis } \\ \text { RNA } & \text { Ribonucleic Acid } \\ \text { Sh2d1b } & \text { SH2 Domain Containing 1B } \\ \text { SIRP } \alpha & \text { Signal-Regulatory Protein Alpha } \\ \text { Signaling Lymphocytic Activation Molecule } \\ \text { Her }\end{array}$




$\begin{array}{ll}\text { SLE } & \text { Systemic Lupus Erythematosus } \\ \text { SNF1 } & \text { (NZBxSWR)F1 } \\ \text { TCR } & \text { T Cell Receptor } \\ \text { TGF- } \beta & \text { Transforming Growth Factor Beta } \\ \text { T }_{\text {H }} & \text { T Helper } \\ \text { TNF } & \text { Tumor Necrosis Factor } \\ \text { Treg } & \text { Regulatory T cell } \\ \text { TSP-1 } & \text { Thrombospondin-1 }\end{array}$




\section{CURRICULUM VITAE}

\section{Colleen F. Tucker}

\section{CONTACT:}

Address: 1826 Sherwood Ave. Apt. 2

Louisville, Ky. 40205

Phone: $\quad$ (502) 523-7787, Work: (502) 852-6209

Fax: $\quad 502-852-7531$

Email: $\quad \underline{\text { cftuck01@gwise.louisville.edu }}$

\section{EDUCATION:}

2001-2004 B.S., Biology Major, Math Minor University of Kentucky, Lexington, KY

2005-2006 M.S., Immunology and Microbiology University of Louisville, Louisville, KY

2005-present Ph.D. Candidate, Immunology and Microbiology University of Louisville, Louisville, KY

\section{HONORS AND AWARDS:}

2001-2004 Dean's List, University of Kentucky

2005-2007 Integrated Programs in Biomedical Sciences Fellowship

2009 University of Louisville Graduate Student Council Travel Award

2009 First Place Graduate Student Research Research! Louisville 


\section{TEACHING EXPERIENCE:}

2004-2005 Taught Pre-Calculus, $11^{\text {th }} \& 12^{\text {th }}$ grade

Walden High School

Louisville, KY

\section{PROFESSIONAL POSITIONS:}

2002-2003 Student Lab Technician

Department of Agriculture

University of Kentucky

- Provided support for research on the Wolbachia virus and it's effect on the fertility/virility of mosquitoes, both raised in our facility and collected from local farms

2004-2005 Lab Technician

Department of Surgery

University of Louisville

- Research focused on hyperglycemia and it's role in susceptibility to infections, specifically the effect of hyperglycemia on neutrophil apoptosis and activation of mononuclear cells

2005-present Graduate Student

Department of Microbiology and Immunology

University of Louisville

- Thesis: Gender differences in regulatory T cells and their role in systemic lupus erythematosus

\section{MEMBERSHIPS IN PROFESSIONAL ORGANIZATIONS:}

2007-present American Association of Immunologists, Student Member

2005-present Microbiology and Immunology Student Organization, University of Louisville

\section{PROFESSIONAL ACTIVITIES:}

2005-2007 President, Microbiology and Immunology Student Organization, University of Louisville 


\section{ABSTRACTS:}

1. Tucker CF, Nebane-Ambe D, Parnell SA, Manirarora JN, Alard P, and Kosiewicz MM. Sex differences in regulatory $T$ cells in a mouse model of systemic lupus erythematosus. Research! Louisville, 2007. (Poster Presentation)

2. Tucker CF, Alard P, Parnell SA, Manirarora JN, Nebane-Ambe D, and Kosiewicz MM. Age-Related changes in regulatory cell populations and function in lupus-prone mice. American Association of Immunologists $95^{\text {th }}$ Annual Meeting, San Diego 2008. (Poster Presentation)

3. Tucker CF, Parnell SA, Nebane-Ambe D, Alard P, and Kosiewicz MM. Gender differences in regulatory $\mathrm{T}$ cell populations and disease progression in lupus-prone mice. Research! Louisville, 2008. (Poster Presentation)

4. Tucker CF, Parnell SA, Alard P, and Kosiewicz MM. Analysis of gender-based disparity in Treg populations in young lupus-prone mice. American Association of Immunologists $96^{\text {th }}$ Annual Meeting, Seattle 2009. (Poster Presentation)

5. Tucker CF, Parnell SA, Alard P, and Kosiewicz MM. Analysis of Treg defects in female (NZBxNZW)F1 mice with established disease. American Association of Immunologists $96^{\text {th }}$ Annual Meeting, Seattle 2009. (Poster Presentation)

6. Tucker CF, Parnell SA, Nebane-Ambe D, Alard P, and Kosiewicz MM. A Role for Regulatory T Cells in Gender-biased Disease Susceptibility in Systemic Lupus Erythematosus. Research! Louisville, 2009. (Poster Presentation)

\section{BIBLIOGRAPHY:}

1. Turina M, Miller FN, Tucker CF, and Polk HC. Short-term hyperglycemia in surgical patients and a study of related cellular mechanisms. Ann. Surg. (2006) 243(6): 845-853.

2. Tucker CF, Nebane-Ambe D, Alard P, Parnell SA, and Kosiewicz MM. Autoimmuneprone strains of mice are deficient in the potent $\mathrm{CD}_{103}{ }^{+}$subset of $\mathrm{CD} 4^{+} \mathrm{CD} 25^{+}$regulatory T cells. (Submitted for publication)

3. Tucker CF, Nebane-Ambe D, Alard P, Parnell SA, Manirarora JN, Zhao Y, and Kosiewicz MM. Autoimmune-prone strains of mice display gender differences in regulatory $\mathrm{T}$ cell populations. (In preparation)

4. Tucker CF, Nebane-Ambe D, Alard P, Parnell SA, Manirarora JN, Zhao Y, and Kosiewicz MM. Sex differences in regulatory $T$ cell populations change throughout disease progression in (NZBxNZW)F 1 lupus-prone mice. (In preparation) 